UNITED STATES DEPARTMENT OF THE INTERIOR

Harold L. Ickes, Secretary

GEOLOGICAL SURVEY

W. C. Mendenhall, Director

Water-Supply Paper 680

DROUGHTS OF 1930-34

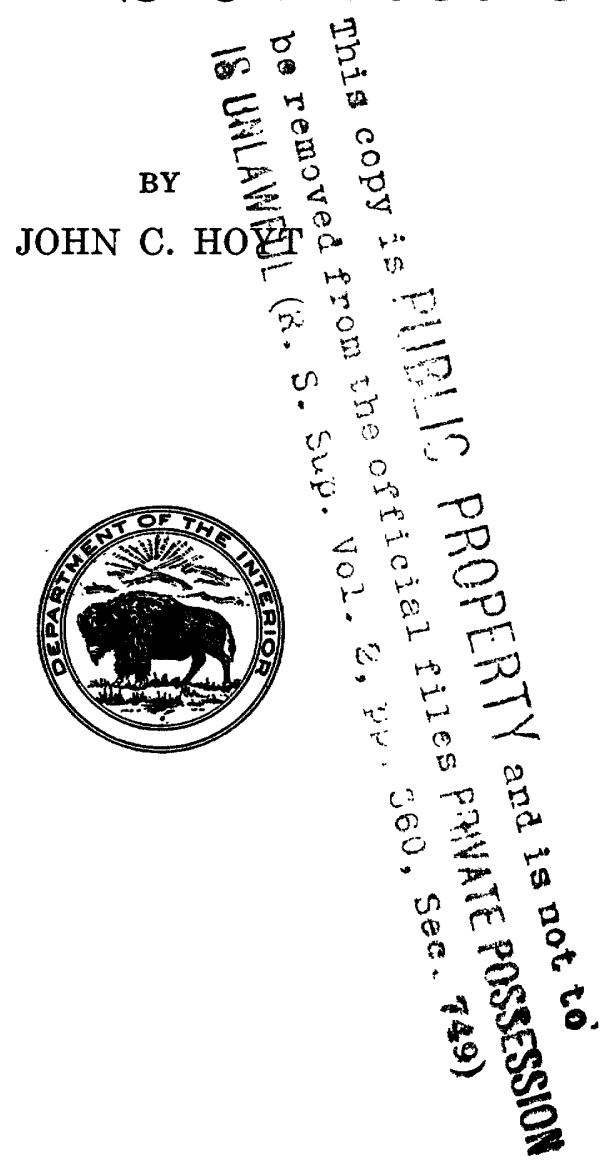

UNITED STATES

GOVERNMENT PRINTING OFFICE

WASHINGTON : 1936 


\section{CONTENTS}

Page

Introduction

Droughts of 1930 and 1931

Causes....... 6

Precipitation 6

Temperature

Wind

Effect on ground and surface water... 11

General effect.................. 11

Ground water.......... 22

Surface water..... 26

Damage-......... 32

Vegetation........ 32

Domestic and industrial water supplies............ 36

Health..... 37

Power.... 38

Navigation....... 39

Recreation and wild life....... 41

Relief

Drought of 1934

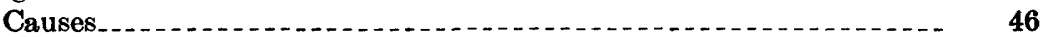

Precipitation. 47

Temperature

Wind

Effeet on ground and surface water.... 53

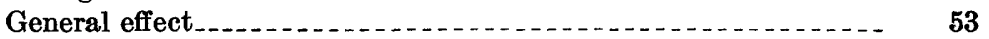

Ground water

Surface water. 54

Damage.......

Vegetation.

Domestic and industrial water supplies. 59

Health.... 60

Power. 61

Navigation............. 61

Recreation and wild life

Relief

Comparison of droughts during period 1881 to 1934

Drought and low-water stream flow

Carry-over effect as related to drought._.

Alleviation of drought damage. 71

Precipitation diagrams....

Index._. 


\section{ILLUSTRATIONS}

Prate 1. Precipitation by States for major drought years... Page

Figure 1. Drought years, 1881 to 1934

2. Accumulated departures from the mean of the monthly precipitation for the periods of 31 months including the 3 years of lowest precipitation in Virginia............. 10

3. Temperatures, 1930 ......... 12

4. Temperatures, $1931 \ldots 12$

5. Diagrammatic section showing different kinds of discharge of subsurface water.

6. Gage-height graph of South Fork of Mills River at The Pink Beds, N. C., showing diurnal and seasonal effect of evaporation and transpiration.

7. Gage-height graph of Owens Creek at Lantz, Md., June 1-5, 1932, showing effect of transpiration and evaporation on stream flow

8ischarge graph of Piney Run near Sykesville, Md., showing effect of transpiration, evaporation, and altitude of water table on stream flow . . . .

9. Fluctuation of water surface of Ross well, Arlington, Va., and precipitation at Washington, D. C., 1928-34_.........

10. Fluctuation of water surface of a well, run-off, and precipitation on South Branch of Moose River in New York, 192834_.

11. Rainfall and run-off for combined drainage basins of Tennessee and Cumberland Rivers, by months, showing variation between wet and dry years.

12. Accumulated departures from the average of the monthly discharge of Potomac River at Point of Rocks, Md., and of the precipitation recorded at Westernport and Frederick, Md.

13. Total precipitation for June, July, and August and composite yields of crops per acre, expressed as percentage of average

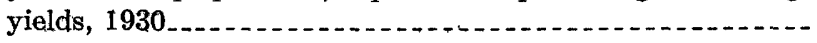

14. Total precipitation for June, July, and August and composite yields of crops per acre, expressed as percentage of average

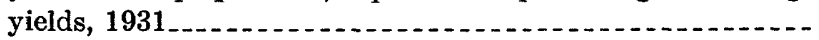

15. Relation of composite yields of crops per acre in 1930 and 1931 to total precipitation in June, July, and August for the 36

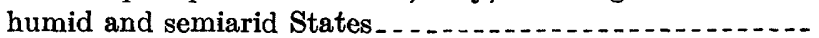

16. Areas where Red Cross gave drought relief, August 1930 to June 1931 . . . . . . .

17. Temperatures, 1934

18. Total precipitation for June, July, and August and composite yields of crops per acre expressed as percentage of average yields, 1934

19. Percentage of area having deficiencies in precipitation of 15 percent or more, 1881-1934 
Frgure 20. Location of river-measurement stations used to show the relation of drought and stream flow

21. Annual precipitation in Maine, 1881-1934, and monthly precipitation, June 1929 to December 1931.

22. Annual precipitation in New Hampshire, 1881-1934, and monthly precipitation, June 1929 to December 1931 . . . . . . . -

23. Annual precipitation in Vermont, 1881-1934, and monthly precipitation, June 1929 to December 1931 . . . . . . . . . . . . . . .

24. Annual precipitation in Massachusetts, 1881-1934, and monthly precipitation, June 1929 to December 1931 ........ -

25. Annual precipitation in Rhode Island, 1881-1934, and monthly precipitation, June 1929 to December 1931 .........

26. Annual precipitation in Connecticut, 1881-1934, and monthly precipitation, June 1929 to December 1931 . . . . . . . . -

27. Annual precipitation in New York, 1881-1934, and monthly precipitation, June 1929 to December 1931 ...............

28. Annual precipitation in New Jersey, 1881-1934, and monthly precipitation, June 1929 to December 1931 ....... . . . . . . .

29. Annual precipitation in Pennsylvania, 1881-1934, and monthly precipitation, June 1929 to December 1931 . . . . . . . . . . . .

30. Annual precipitation in Maryland-Delaware, 1881-1934, and monthly precipitation, June 1929 to December 1931 ..... . . .

31. Annual precipitation in Virginia, 1881-1934, and monthly precipitation, June 1929 to December 1931 .

32. Annual precipitation in North Carolina, 1881-1934, and monthly precipitation, June 1929 to December 1931 .........

33. Annual precipitation in South Carolina, 1881-1934, and monthly precipitation, June 1929 to December 1931 .

34. Annual precipitation in Tennessee, 1881-1934, and monthly precipitation, June 1929 to December $1931 \ldots$

35. Annual precipitation in Kentucky, 1881-1934, and monthly precipitation, June 1929 to December 1931 ...... . . . . . . . .

36. Annual precipitation in West Virginia, 1881-1934, and monthly precipitation, June 1929 to December 1931 .........

37. Annual precipitation in Ohio, 1881-1934, and monthly precipitation, June 1929 to December $1931 \ldots$

38. Annual precipitation in Michigan, 1881-1934, and monthly precipitation, June 1929 to December 1931 ................

39. Annual precipitation in Indiana, 1881-1934, and monthly precipitation, June 1929 to December $1931 \ldots$

40. Annual precipitation in Illinois, 1878-1934, and monthly precipitation, June 1929 to December 1931 . . . . . . . . . .

41. Annual precipitation in Arkansas, 1881-1934, and monthly precipitation, June 1929 to December 1931 ...............

42. Annual precipitation in Missouri, 1881-1934, and monthly precipitation, June 1929 to December 1931 ... . . . . . . . . . .

43. Annual precipitation in Iowa, 1873-1934, and monthly precipitation, June 1929 to Deer w ber 1931 . . . . . . . . . . . . .

44. Annual precipitation in Wis. nsin, 1881-1934, and monthly precipitation, June 1929 to December 1931 . . . . . . . . . . .

45. Annual precipitation in Minnesota, 1881-1934, and monthly precipitation, June 1929 to December 1931 
FIgure 46. Annual precipitation in Florida, 1881-1934, and monthly precipitation, June 1929 to December 1931

47. Annual precipitation in Georgia, 1881-1934, and monthly precipitation, June 1929 to December 1931

48. Annual precipitation in Alabama, 1881-1934, and monthly precipitation, June 1929 to December 1931

49. Annual precipitation in Mississippi, 1881-1934, and monthly precipitation, June 1929 to December $1931 \ldots \ldots$. . . . . . . . . .

50. Annual precipitation in Louisiana, 1881-1934, and monthly precipitation, June 1929 to December $1931 \ldots$

51. Annual precipitation in Oklahoma, 1881-1934, and monthly precipitation, June 1929 to December 1931 . . . . . . . . . . . .

52. Annual precipitation in Kansas, 1881-1934, and monthly precipitation, June 1929 to December 1931 . . . . . . . . . . .

53. Annual precipitation in Nebraska, 1876-1934, and monthly

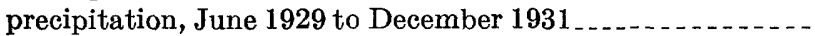

54. Annual precipitation in South Dakota, 1881-1934, and monthly precipitation, June 1929 to December 1931 ........

55. Annual precipitation in North Dakota, 1881-1934, and monthly precipitation, June 1929 to December 1931 . . . . . . . . . . .

56. Annual precipitation in Texas, $1881-1934$, and monthly precipitation, June 1929 to December 1931 . . . . . . . . . . . . . . .

57. Annual precipitation in New Mexico, 1881-1934, and monthly precipitation, June 1929 to December 1931 . . . . . . . . . . . .

58. Annual precipitation in Colorado, 1881-1934, and monthly precipitation, June 1929 to December 1931

59. Annual precipitation in Wyoming, 1881-1934, and monthly precipitation, June 1929 to December 1931.

60. Annual precipitation in Montana, 1881-1934, and monthly precipitation, June 1929 to December 1931 .

61. Annual precipitation in Idaho, 1881-1934, and monthly precipitation, June 1929 to December 1931

62. Annual precipitation in Nevada, 1881-1934, and monthly precipitation, June 1929 to December 1931 _ . . . . . . . . . . . . . .

63. Annual precipitation in Utah, 1881-1934, and monthly precipitation, June 1929 to December $1931 \ldots$

64. Annual precipitation in Arizona, 1881-1934, and monthly precipitation, June 1929 to December 1931

65. Annual precipitation in California, 1881-1934, and monthly precipitation, June 1929 to December 1931 ......... . . . . . -

66. Annual precipitation in eastern Oregon, 1890-1934, and monthly precipitation, June 1929 to December 1931 ........

67. Annual precipitation in western Oregon, 1890-1934, and monthly precipitation, June 1929 to December 1931 ........

68. Annual precipitation in eastern Washington, 1890-1934, and monthly precipitation, June 1929 to December 1931 ... . . . . . -

69. Annual precipitation in western Washington, 1890-1934, and monthly precipitation, June 1929 to December 1931 


\section{TABLES}

1. Annual preeipitation, in inches, by States, 1881-1934

2. Precipitation and composite yields of crops per acre, 1929-34, by States

3. Losses between precipitation and run-off prior to 1906 for the winter and summer months

4. Daily discharge, in second-feet, of Potomac River at Shepherdstown, W. Va., June 1 to December 31, 1930

5. Monthly and yearly discharge, in second-feet, of Potomac River at Point of Rocks, Md., 1895-1931

6. Deficiency table for Potomac River at Point of Rocks, Md., 1897-1931.

7. Composite yields of crops per acre and precipitation in North Carolina, Missouri, and Illinois, 1930

8. Pereentage change in production of electricity for public use in the humid and semiarid sections of the United States, 1929-31 . . . . . . .

9. American National Red Cross drought relief, financial statement......-

10. American National Red Cross drought relief, character and extent of aid . . . . . . . . . .

11. Precipitation, temperature, and crop yields in 1934, by States........

12. Effect of the drought of 1934 on stream flow

13. Water in storage in 24 reservoirs of the United States Bureau of

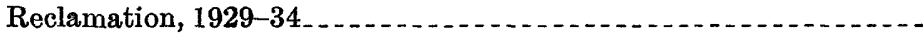

14. Annual precipitation, in percent of mean, by States, 1881-1934 . . ....

15. Number of years when precipitation did not exceed $85,80,75$, or 70 percent of mean and the precipitation for the 6 years in which the precipitation was lowest, for the period 1881 to 1934 , by States

16. Years when large areas of the humid and semiarid States had deficiency in precipitation of 15 percent or more

17. Minimum discharge, in second-feet, at selected river-measurement stations for periods of record ending September 30, 1934 


\title{
DROUGHTS OF 1930-34
}

\author{
By JoнN C. Hотт
}

\section{INTRODUCTION}

During the 5-year period 1930-34 a serious drought occurred over :some broad region of the United States in each year except 1932. The humid States were seriously affected in 1930 and to a lesser extent in 1931 and 1934. The semiarid States underwent minor droughts in 1931 and 1933, which added to the catastrophe of 1934 . Drought conditions during these years are of more than academic interest. They stand out as a limiting basis in the availability of surface and ground waters in works involving many millions of capital outlay. If future water supplies are to be unfailing, sufficient storage must be provided to withstand the recurrence of similar shortages at any time.

This report summarizes, as an aid to the more detailed analyses that will arise in the consideration of specific projects, some of the more outstanding questions related to droughts, both physical and economic. It outlines the nature and extent of the droughts of 1930-34; compares them with past dry periods in terms of precipitation, run-off, ground water, evaporation, and transpiration; and sketches the effects of droughts on water supplies as related to a variety of human purposes, including agriculture, domestic and industrial uses, health, power, navigation, and recreation and wild life; it also touches upon the relief, political, and economic elements.

This report is based on information collected in the various States under the direction of the 36 district engineers of the United States Geological Survey, supplemented by data made available through the United States Weather Bureau, Bureau of Agricultural Economics, Bureau of Public Health Service, Office of the Chief of Engineers, Bureau of Reclamation, Emergency Relief Administration, American National Red Cross, and various State agencies. The assistance and suggestions of Geological Survey engineers and geologists and of the personnel of the other organizations listed above is hereby acknowledged. In the arrangement and preparation of the tables and graphs special assistance has been given by Lloyd L. Harrold, Francis M. Bell, and Arthur H. Frazier, assistant engineers, United States Geological Survey. The suggestions of J. B. Kincer, chief of the Division of Climate and Crop Weather, United States Weather Bureau; 
Edward T. Kotok, director California Forest and Range Experiment Station, United States Forest Service; and Guy C. Stevens, hydraulic engineer, United States Geological Survey, have been especially helpful.

When in an area that is ordinarily classed as humid natural vegetation becomes desiccated or defoliates unseasonably and crops fail to. mature owing to lack of precipitation, or when precipitation is insuffcient to meet the needs of established human activities, drought conditions may be said to prevail. Although water for irrigation or other uses in arid areas is always limited, special shortages in such areas are also regarded as droughts. Unsatisfactory distribution of precipitation throughout the year may be as effective a factor in causing a drought as a shortage in the total amount. Temperature and wind may also. play an important part, especially in relation to the damage done.

As interest in droughts may relate either to their physical characteristics, as determined by the phenomena that cause them, or to their economic effects, as reflected by damage, they may be considered either as a natural phenomenon or as an economic phenomenon-usually both-and it is therefore essential to take into account in drought studies not only physical data but also information as to the extent and nature of human activities in the area affected.

Although a deficiency in precipitation is the prime cause of droughts. it is not possible to set for any region an exact limit of the total annual precipitation above which a drought does not exist and below which a drought may be produced. In general, however, in the humid and semiarid States serious drought effects do not result unless the annual precipitation is as low as 85 percent of the meanthat is, an annual deficiency of 15 percent or more. This limit is here used in defining a drought year and will serve for many drought studies. Although no definite limit can be set for the arid States. on account of the wide variations in distribution of precipitation within these States, the same criterion has been used for certain comparisons in this report.

Under the definition given above there have been 38 droughts in the humid States during the period 1881-1934, and in 12 of these droughts over 23 percent of the area of the States was affected. In the semiarid States there were 28 droughts during the same period, and in 11 of these droughts over 44 percent of the area was affected. The years in which these droughts occurred are shown by the black portions of the squares on figure 1. Each square represents a year. The one in the upper left corner represents the year 1880; the next to the right is 1881 , then 1882 , etc. The horizontal dimension of the black portion of a square indicates the percentage of the area in which there was a drought. If the entire width of the square is black 100 . percent of the area was affected. The vertical dimension indicates the deficiency in precipitation, expressed in percentage of the mean annual. 
Records of precipitation and stream flow give an index for studying droughts and generally will serve to answer questions relative to the area covered, the severity, the frequency, and the duration. Additional facts, however, are needed in considering the nature and extent

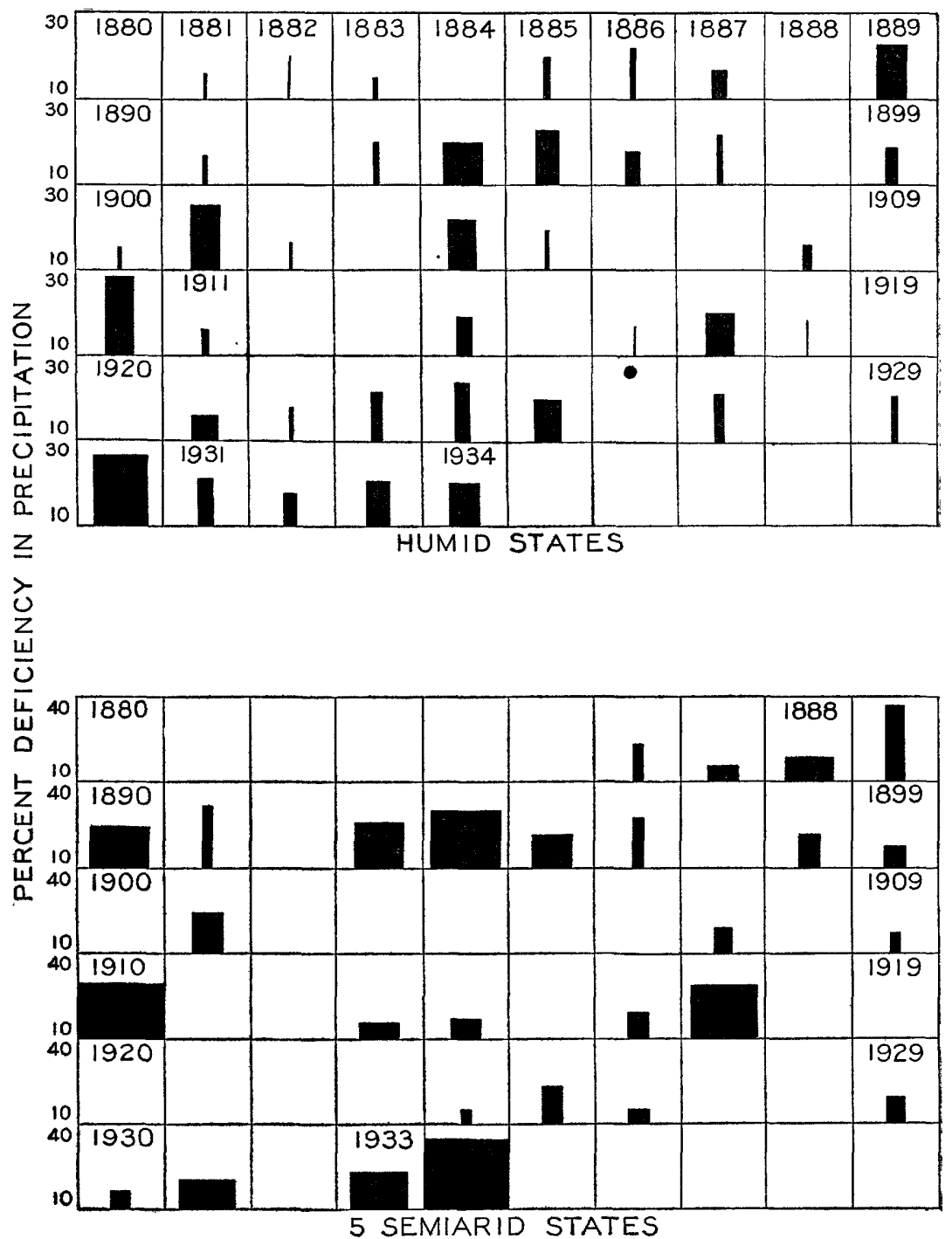

(North Dakota, South Dakota, Nebraska, Kansas, and OKlahoma)

Figure 1.-Drought years, 1881-1934.

of resulting damages. Press statements relative to droughts that appear before full physical and other information have been made available and analyzed are generally exaggerated and should be used with caution. 
The records of precipitation and stream flow used in this study were made available through the United States Weather Bureau and the United States Geological Survey. Unfortunately, neither of these sets of records extends over a period long enough to enable adequate consideration of drought conditions. Precipitation data are incomplete and scattering for years prior to 1889 , and records of monthly precipitation by States were not generally made until about 1890 . The annual precipitation for each State ${ }^{1}$ has been compiled by the Weather Bureau on a comparable basis, beginning with 1881, and is given in table 1 . In the years prior to 1895 the number and distribution of precipitation stations in many States were inadequate, and as a result it was necessary to make adjustments in order to bring the records on a comparable basis. The annual precipitation for each State is indicated graphically in figures 21 to 69 (pp. 75-103), which show also the monthly precipitation for each State from June 1929 to December 1931. Records of annual precipitation are indicative only of general drought conditions: to be of value for detailed drought studies they must be supplemented by monthly records, and even then care must be taken in their use. Systematic records of stream flow on a country-wide basis were started in 1895, and there are but few continuous records that began prior to that date.

The climatic character of an area-that is, whether it is humid, arid, or semiarid-is a major factor in determining the effects of droughts. The one hundredth meridian is commonly considered the approximate border line between the humid and arid sections of the United States. There is, however, no well-defined line, as a wide belt extending on both sides of this meridian may be either humid or arid, depending upon the weather conditions in any particular year. This belt, which includes North Dakota, South Dakota, Nebraska, Kansas, Oklahoma, and western Texas, is sometimes called the "Great Plains" and is the principal semiarid section of the country. The 31 States east of this belt and eastern Texas can all be classed as humid, and the 11 States to the west can be classed in the main as arid with the exception of the Pacific Northwest, which is humid.

Agricultural and many other activities are conducted so differently in these three groups of States that for the consideration of droughts on a comparable basis each group must be treated separately. The precipitation, stream flow, and other data used in this report are included for all three groups. The discussion based on these data, however, applies primarily to the humid and semiarid States unless otherwise stated.

There are alternating periods in which precipitation and resulting ground and surface water supplies are successively above or below

1 This report follows the Weather Bureau publications in treating Delaware and Maryland as a unit. 


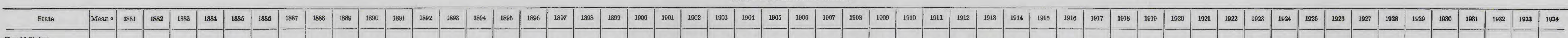

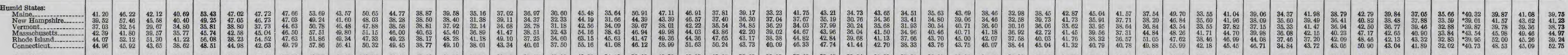

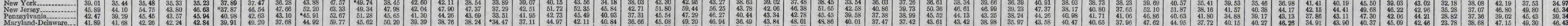

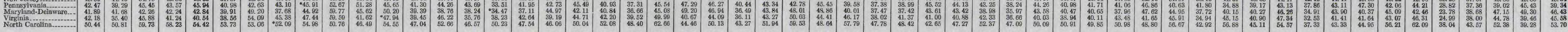

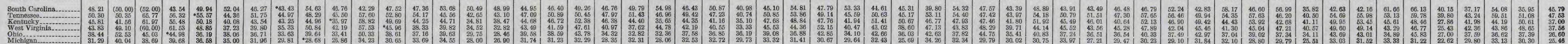

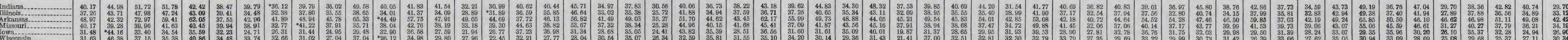

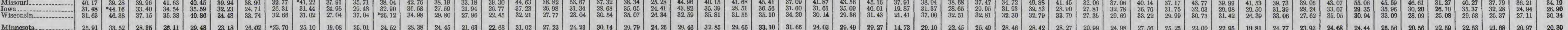

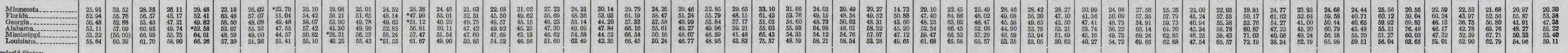

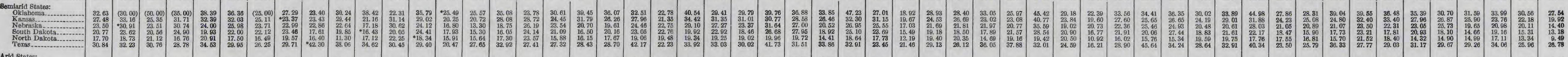

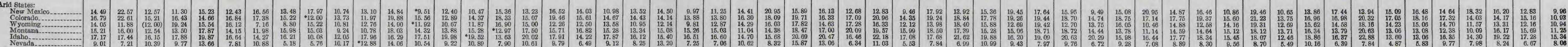

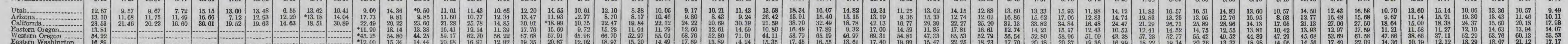

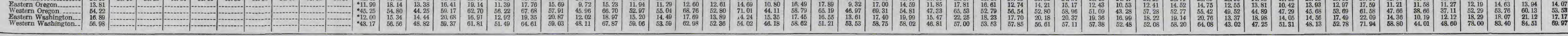


normal. The records, however, do not disclose - at least on the basis of present interpretation-that these periods conform to fixed cycles or that their occurrence is affected by any acts of man. Man's relation to drought has to do with damages and not causes. In the main, droughts result from climatic conditions immediately before or during the drought period, and the only effect of climatic conditions of previous years relates to any excess of precipitation that may have accrued to surface- and ground-water storage. Such accretion aids in alleviating damages during drought years, especially in the arid sections.

Attention has usually been drawn to droughts by their economic, social, and political aspects, as related to human activities, and not by their physical side. In earlier years they were judged largely by the extent of their damage to vegetation, especially agricultural crops. In recent years, however, as demands and uses of water have increased, more consideration is directed to the effect of droughts on surface and ground water supplies as related to normal activities. Therefore, in determining the damages and losses caused by a drought in a given area many factors must be considered. Among these are the climatic conditions, geology, topography, character and extent of agriculture and other activities, and facilities for the conservation and storage of water. The whole drought problem is so complex that it is difficult to compare those that occur in different areas or in different years. A drought in a certain locality may be detrimental to vegetation and not to water supply, or vice versa.

Water-supply conditions for the 5-year period 1930-34 fully indicate that we have now reached a point in the development of the country when serious consequences will result unless much more careful consideration is given to droughts than has been given in the past. Modern needs and uses for water are rapidly exceeding the limits of free natural supplies. Cities and industries are not only undertaking the full utilization of local supplies but are seeking remote sources. Provision of adequate supplies during low-water periods is becoming more and more of a problem. The economic losses that will result from interruption of service, on the one hand, or from overdevelopment, on the other, can be reduced only through. accurate knowledge of frequency, duration, and quantity of minimum. surface-water flows and ground-water yields during periods of drought.

\section{DROUGHTS OF 1930 AND 1931}

Unfavorable crop reports and low stream flow early in the summer of 1930 first called attention to the approaching seriousness of the drought. These were followed by reports from many localities of the shortage of water supplies for domestic and other uses. The principal drought area was in the north Atlantic, Ohio River, and Great Lakes 
drainage basins. By the middle of the summer the effects of the drought were receiving general attention by the press of the country, and the situation was referred to as "the great drought of 1930." At the end of the summer it became evident that in many localities relief measures would be necessary, and steps were taken by both private and governmental agencies to meet needs as they arose. Differences of opinion as to methods of providing the relief created marked political issues and resulted in much emotional publicity, in which great emphasis was given to conditions in certain localities where the effects of the drought were most severe. All this tended to magnify the unfavorable aspects of the situation.

\section{CAUSES}

The climatic conditions--deficient and poorly distributed precipitation, high temperatures, and hot winds-which are the basic cause of all droughts, have been summarized from Weather Bureau statistics in table 2 and on plate 1 and figures $3,4,13$, and 14 . These tables and figures, with graphs on figures 21 to 69 , provide a basis for studying the progress of the droughts of 1930 and 1931 in each State and for making comparisons between other States. During 1928-29 the annual precipitation was generally in excess of normal, and although deficiency in monthly precipitation appeared in later months of 1929 the records indicate that at the beginning of 1930 water conditions were practically normal and that the droughts of 1930 and 1931 cannot in any large measure be attributed to conditions that occurred in preceding years.

\section{PRECIPITATION}

During 1930 precipitation was 85 percent of the mean or less in 27 States. This deficiency was rather uniformly distributed throughout the year, as indicated on the monthly graphs in figures 21 to 69 , and was accompanied by excessive heat and warm winds, which resulted in wide-spread droughts varying in severity in different localities.

The precipitation in 1930 exceeded 85 percent of the mean in only 9 of the 31 humid States. It was above normal in only 1, Florida, and in 12 it was the lowest on record. These 12 States were in the North Atlantic, Ohio River, and Great Lakes drainage basins, and the deficiency was greatest in Maryland and Delaware, West Virginia, Virginia, and Kentucky, where the precipitation ranged from 57 to 61 percent of the mean. In the 6 semiarid States precipitation was below 94 percent of the mean in only 2-North Dakota, 84 percent; South Dakota, 87 percent-and no previous records of minima were broken. In the 11 arid States the precipitation was above normal except in Montana, Idaho, Washington, 


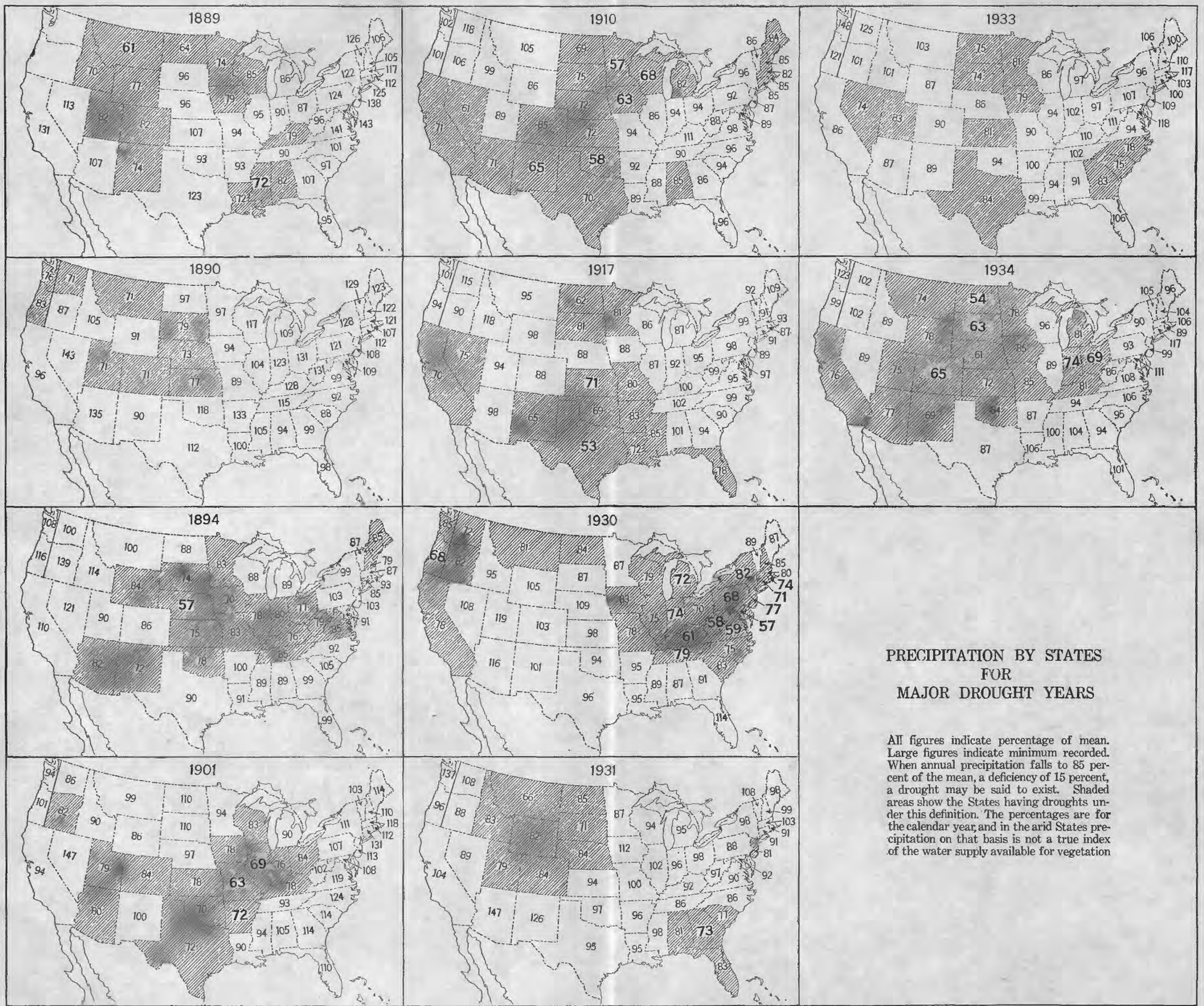


Oregon, and California, and in these 5 States it was below 85 percent except in Idaho (95 percent). In western Oregon it was only 68 percent of the mean, breaking all records of previous lows.

Deficiencies in precipitation continued during the first 10 months of 1931, but they were not as great or wide-spread as during the corresponding period in 1930 , and the distribution of precipitation was much better. November and December 1931 were months of high precipitation, which made up for the deficiencies earlier in the year and brought the annual precipitation to more than 85 percent of the mean in 35 States.

In 1931 the precipitation was 85 percent or less in only 5 of the humid States-Alabama, Florida, Georgia, South Carolina, and New Jersey. It was lowest in Georgia, with 73 percent, which broke all records of previous lows. There were only 2 semiarid States in which the precipitation was below 85 percent-Nebraska, 84 percent, and South Dakota, 71 percent, the latter breaking previous records. Precipitation in all the arid States was 82 percent or more, except Montana, 66 percent, and Utah, 79 percent, and no previous records were broken, but there were areas where water

- supplies for irrigation were short, owing largely to unfavorable distribution of precipitation and inadequate storage. An example is California, where, although the annual precipitation was 104 percent of the mean, agriculture was seriously affected by water shortages.

Although in 1931 deficiency in the precipitation was not extreme in most States, it was sufficient, with the possible carry-over effects from the drought of 1930 , to cause many localities to suffer from shortages in both surface-water and ground-water supplies. Vegetation, however, was not materially affected, as there was ample precipitation during the growing season to supply both natural growth and agricultural crops.

A comparison of the 1930-31 drought with other droughts is given on pages $65-69$. 


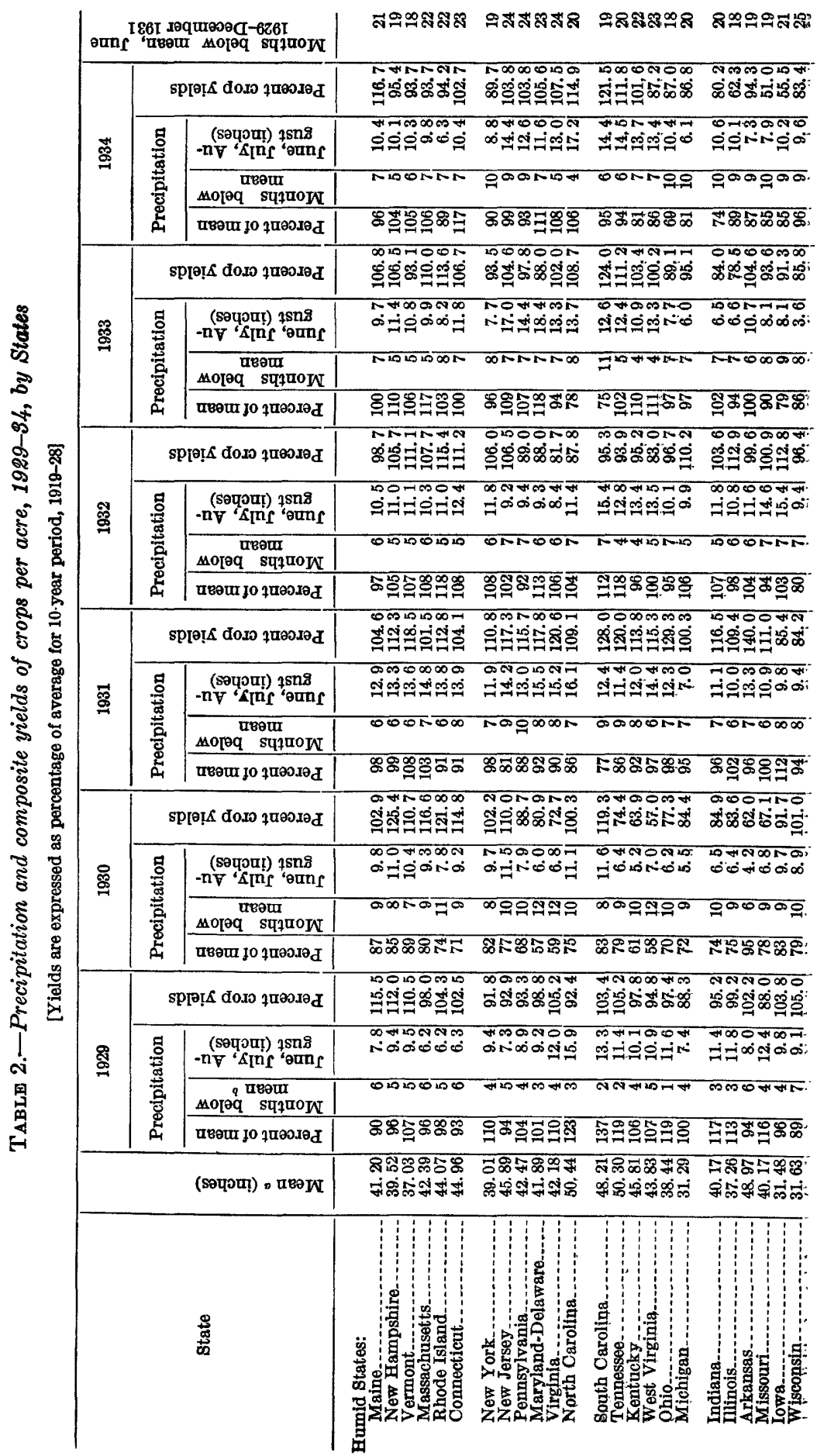




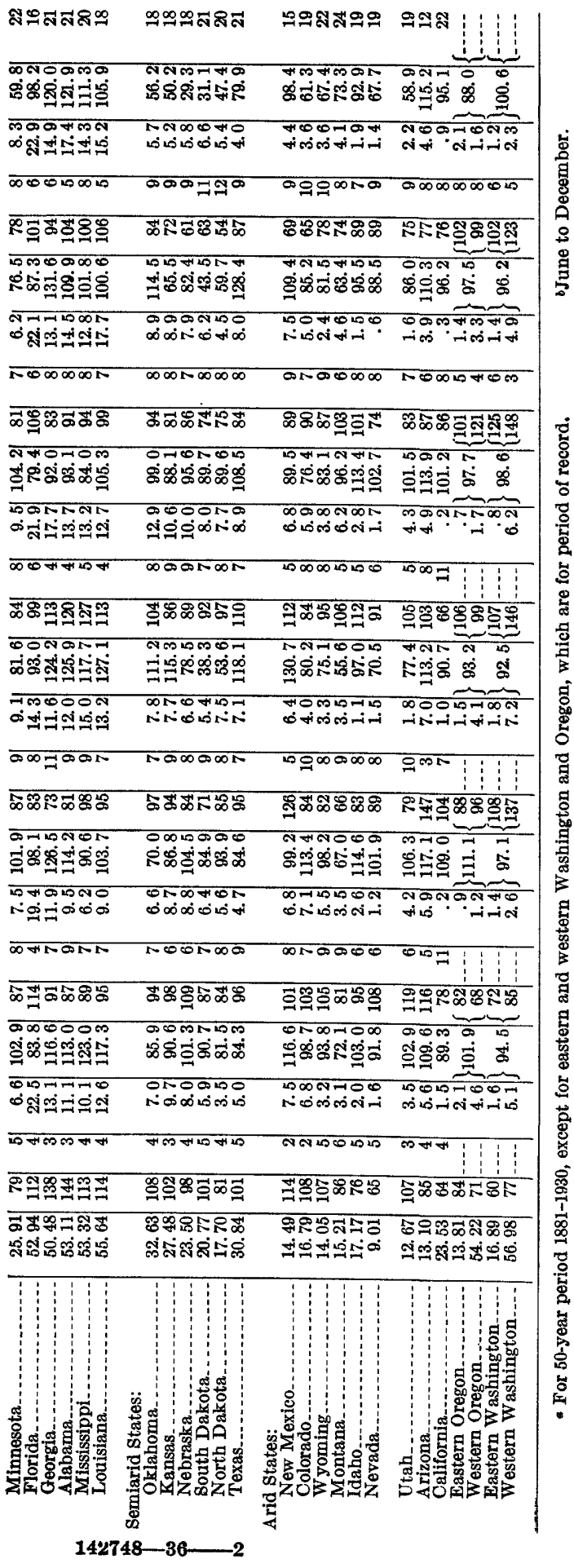


The mean precipitation for each State for the years 1881-1930 is given in table 2. The table also gives for the years 1929-34 the precipitation expressed in percent of the 50-year mean, the number of months for each year when the average precipitation was below the mean for the respective months, the total precipitation for the growing months, June, July, and August, and the crop yields in percent of normal. In most States the deficiency in monthly precipitation started in the later months of 1929 and persisted throughout 1930 and the first 10 months of 1931, as shown in figures 21 to 69 . During this 31-month period the number of months when the precipitation was below the mean ranged in the various humid and semiarid States from 16 to 25 .

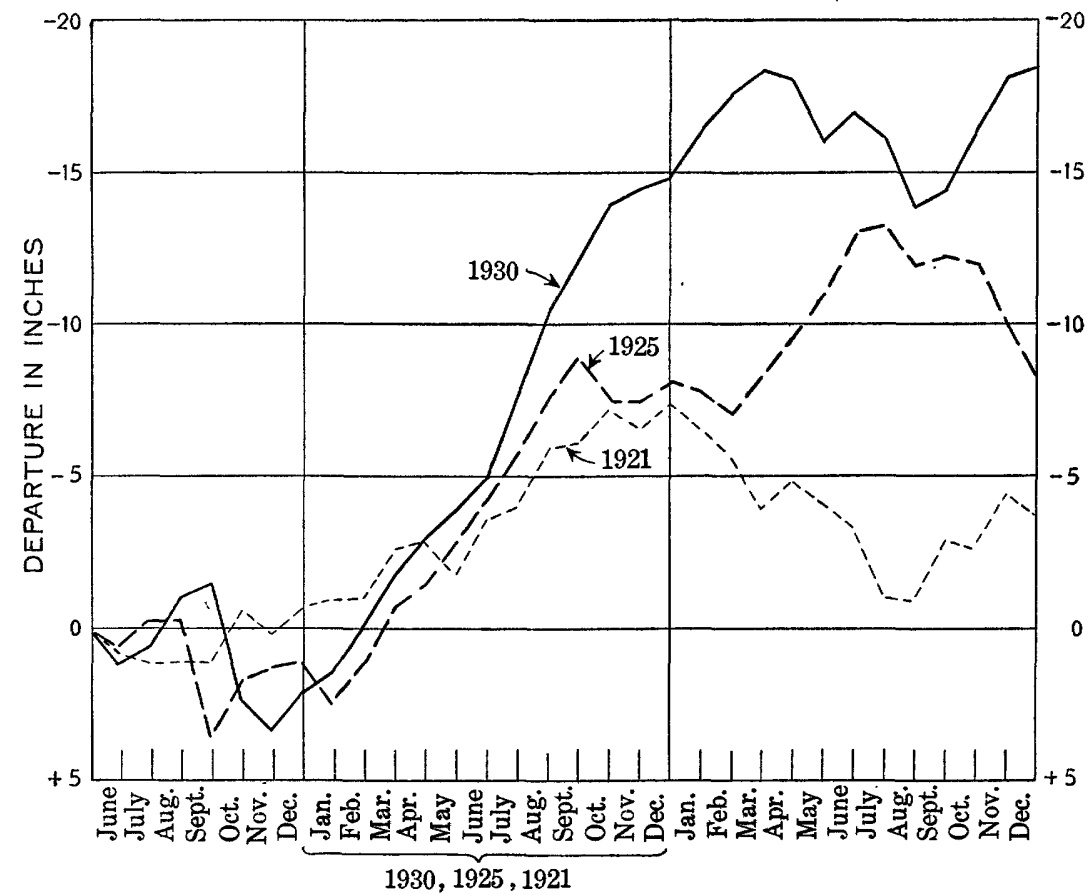

Figure 2.-Accumulated departures from the mean of the monthly precipitation for the periods of 31 months including the 3 years of lowest precipitation in Virginia.

In Virginia the three most severe drought years of record were 1921, 1925, and 1930. The graphs in figure 2 indicate the accumulated departures from the mean of the monthly precipitation for three 31-month periods that include these three droughts, thus affording a means of comparing them.

The intensity of each drought is revealed by the steepness of its graph, the duration by the length of time the deficiencies continued to accumulate, and the severity by a combination of the two. For example, the graph from February to September 1925 is almost as 
steep as that for the corresponding period in 1930, indicating that the intensity of the drought was nearly the same for that period during both years. In the drought of 1930 , however, the deficiencies in precipitation continued to accumulate for 6 months longer, and for that reason this drought is classed as the most severe experienced in Virginia.

Records of stream flow (see pp. 26-32 and table 17) give an even better picture of the drought of 1930-31 and also another means for comparing it with other major droughts.

\section{TEMPERATURE}

During 1930 and 1931 temperatures in the drought area were unusually high, as indicated in figures 3 and 4 . In 1930 previous recorded maxima were broken in Indiana, Kentucky, Tennessee, Virginia, West Virginia, Maryland, Florida, Alabama, and Mississippi, and they were equaled in Pennsylvania, Louisiana, and New Mexico. In July 1931 previous maxima were broken only in Florida and Idaho and equaled only in Georgia and South Dakota.

\section{WIND}

Warm winds, both in 1930 and in 1931, contributed in a large measure to the effects of the drought on vegetation. In many areas warm winds persisted both night and day and in a large measure may have accounted for low humidity, high evaporation, and absence of the usual dews, which are of great benefit to vegetation.

\section{EFFECT ON GROUND AND SURFACE WATER}

\section{GENERAL EFFECT}

The quantity and distribution of both surface and subsurface water, and also their relation to each other, are determined by a combination of factors, including climate, vegetation, topography, geology, geographic location, and the works of man.

The relation between droughts and water supplies and between water supplies and vegetation depends upon the basic principles of hydrology, and these three subjects are so closely related that it is difficult to consider or discuss any one of them independently of the others.

Of the water that reaches the earth by precipitation, a part is promptly returned to the atmosphere by evaporation; another part remains on the surface, either as snow or impounded water, or in flowing streams, as surface water; and the remainder enters the ground and becomes subsurface water.

With respect to the occurrence of subsurface water ${ }^{2}$ the earth's crust may be divided into the zone of saturation and the zone of

2 See Meinzer, O. E., Occurrence of ground water in the United States: U. S. Geol. Survey Water-Supply Paper 489, 1923; Outline of ground-water hydrology: U. S. Geol. Survey Water-Supply Paper 494, 1923. 


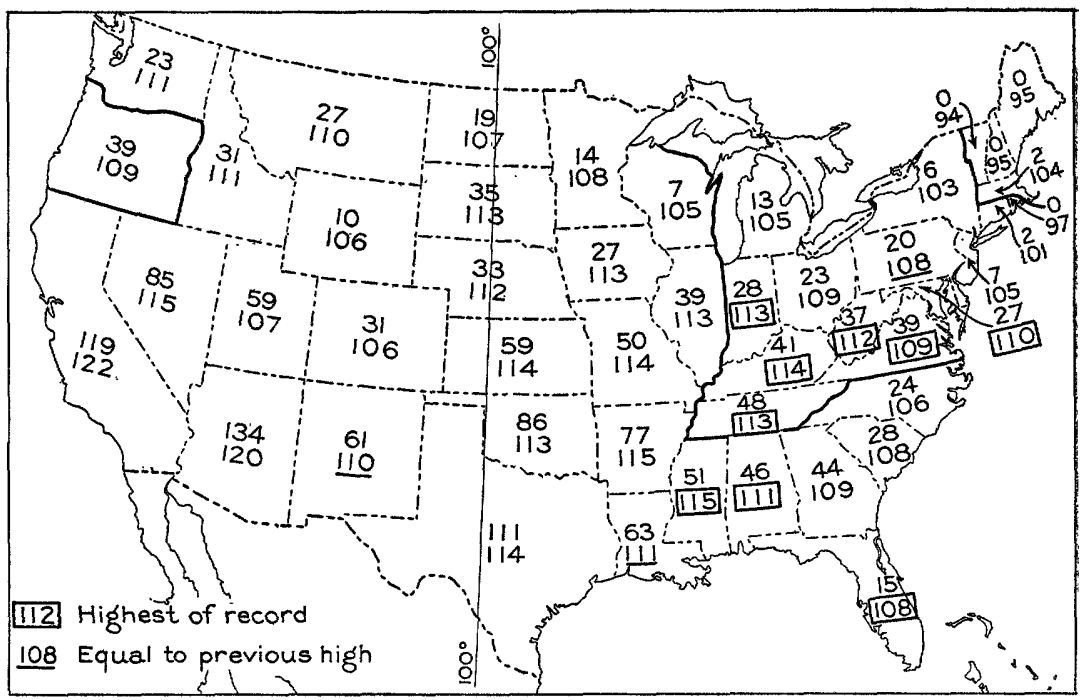

Figure 3.-Temperatures, 1930. Upper figure, number of days with maximum of $100^{\circ} \mathrm{F}$. or more. Lower figure, maximum temperature during June, July, and August. In areas indicated by heavy outline the precipitation in 1930 was lowest of record.

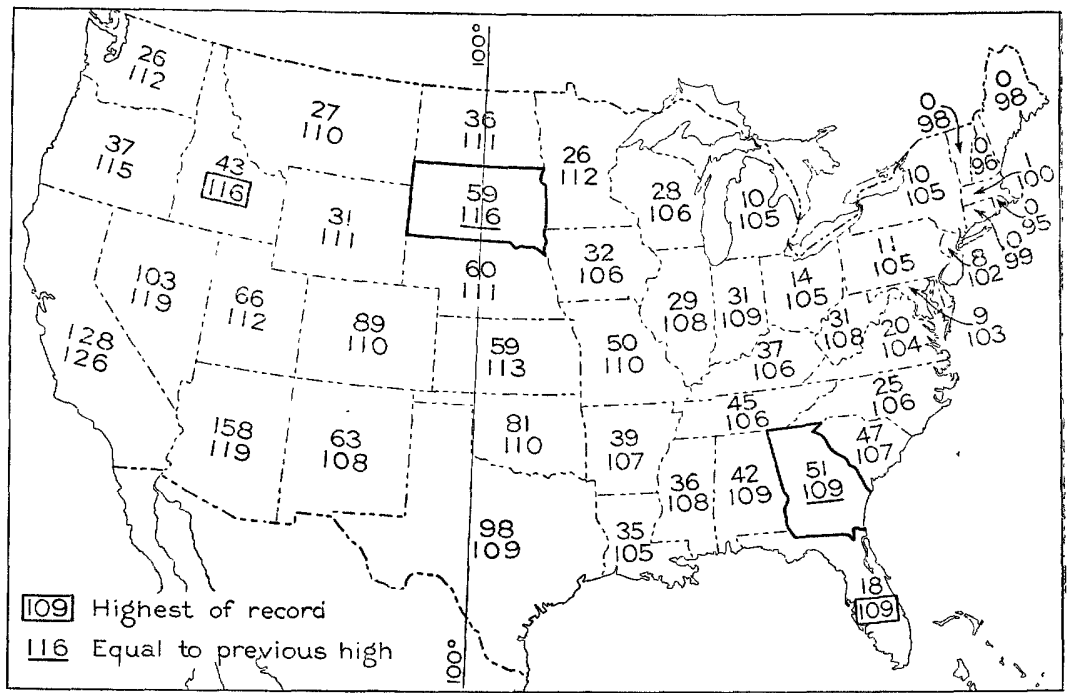

FIGURE 4.-Temperatures, 1931. Upper figure, number of days with maximum of $100^{\circ} \mathrm{F}$. or more. Lower figure, maximum temperature during June, July, and August. In areas indicated by heavy outline the precipitation in 1931 was lowest of record. 
aeration, as indicated in figure 5. In the zone of saturation the interstices are filled with water under hydrostatic pressure. This zone constitutes the great reservoir from which stream flow is maintained and deep-rooted plants are, in part, fed during the periods of slight rainfall. The water in this zone is commonly called "ground water." In the zone of aeration the interstices are largely filled with air. Many of the interstices in this zone contain water, and at times some of them may be completely filled. This water is not, except temporarily, under hydrostatic pressure and is, for the most part, held by molecular attraction. This zone acts as a distributing reservoir, and its water content is subject to rapid fluctuations.

The depth to the water table or upper surface of the zone of saturation varies in different localities, depending on topography and the geologic formation. It also has seasonal variations, which depend on the differences in the rate at which water enters and leaves the zone of

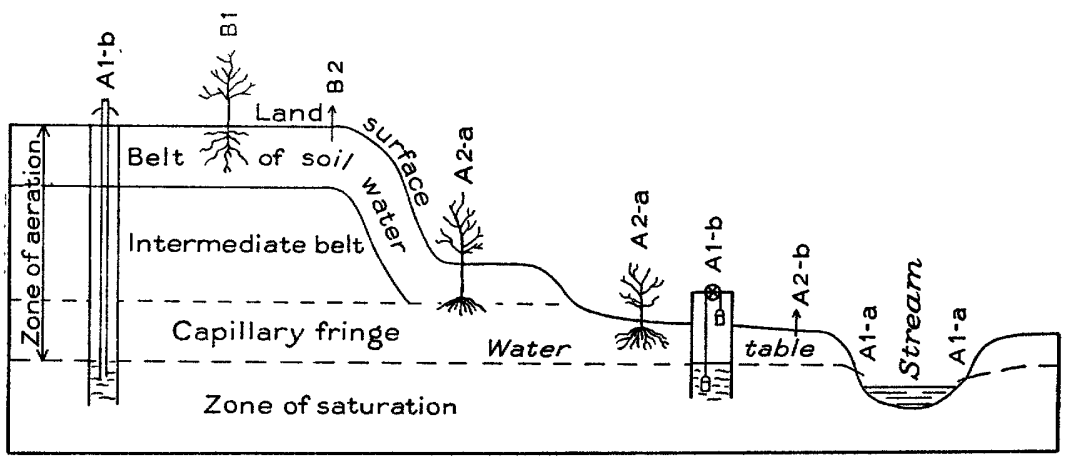

Figure 5.-Diagrammatic section showing different kinds of discharge of subsurface water. $A$, Groundwater or phreatic-water discharge: $A 1-a$, spring; $A t-b$, well; $A \&-a$, phreatophyte; $A \&-b$, soil which is acting like the wick of a lamp in drawing water from the zone of saturation. $B$, Vadose-water discharge: $B-1$, ordinary plant, the roots of which do not extend to the capillary fringe; $B-2$, soil above the capillary fringe, which is losing moisture by evaporation. (After Meinzer.)

saturation. These variations indicate and determine the gradient of the water table. This gradient is important, because its fluctuations correspond to the amount of water that is released from the zone of saturation.

The zone of aeration may be divided, as indicated in figure 5 , with respect to the occurrence and circulation of its water, into the belt of soil water, the capillary fringe, and the intermediate belt.

The belt of soil water is the part of the earth's crust immediately below the surface, from which water is discharged into the atmosphere in perceptible quantities by evaporation from the soil or transpiration from plants. Its thickness is limited by the character of the vegetation and the texture of the soil. It is essentially the same as the so-called "root zone." The capillary fringe is the belt that overlies the zone of saturation and contains interstices, some or all of which contain water 
that is continuous with the zone of saturation but is held above that zone by capillary action against gravity. Its thickness is determined by the texture of the material in which it occurs.

The intermediate belt is the residual part of the zone of aeration. It varies in thickness and will be missing entirely when the belt of soil moisture joins the capillary fringe. In general, the intermediate belt is of but little importance in connection with water supplies.

The precipitation that passes below the surface first enters the belt of soil water, from which it is discharged in four ways-(1) to the atmosphere by evaporation directly from the soil; (2) to plants, which return a large portion of it to the atmosphere by transpiration; (3) to. the surface water by shallow subsurface flow; (4) to the intermediate belt, through which it percolates and ultimately reaches the water table, where it enters the zone of saturation.

Where the water table meets the earth's surface, springs occur and: water flows from the zone of saturation upon the land surface or into a, body of surface water. Where the water table is near the surface, water may be withdrawn from the zone of saturation by evaporation: directly through the soil or by plants, mostly by transpiration. Water is also withdrawn from the zone of saturation through wells, filtration ditches, and tunnels.

The precipitation reaches the surface streams either directly by flow over the surface of the ground or indirectly through the ground, either as suspended water or as ground water. Low-water flows are derived largely from ground water; when this is supplemented by water from the zone of aeration, medium flows exist; and if there is a large contribution from the surface, flood flows are produced.

The relation between vegetation and water is not fully understood, it is not readily susceptible of laboratory study, and there are varyingopinions relative to the many phases that enter into it. Certain principles, however, have been usually agreed to by many students of: the subject. Plants draw their moisture through their root systems: from the earth's zone in which they are embedded and give it off by transpiration through their leaves. Root systems are particularly susceptible to the influence of changes in soil texture and moisture and are more or less modified by environment. There are wide variations in their character. Some penetrate deeply into the soil; others. lie near the surface. The root systems reach out and take the water which is most readily available. Their principal source of supply is. the belt of soil water, and not the zone of saturation, for with the exception of certain trees, the roots of most plants do not extend 
deeply into the ground and, in general, do not reach the water table. Hence, there appears to be but little direct relation between most vegetation, other than deep-rooted trees, and the ground-water table. The principal draft on the zone of saturation by vegetation is that from growth on lands adjacent to watercourses.

During the average growing season practically all the precipitation is lost through evaporation or utilized in plant growth, so that stream flow during the growing period is largely dependent upon ground water. Low flows, therefore, generally prevail except when the precipitation is intense or excessive.

Water in the belt of soil water fluctuates in quantity with precipitation and is continually being lost either by evaporation and transpiration or by percolation laterally to the surface or downward to the zone of saturation. The capacity of the belt of soil water for holding water is comparatively small; therefore the quantity of water available in it is not greatly affected by long-time carry-over derived from previous precipitation. In general this belt contains sufficient water to supply vegetation for only a few weeks, and during the growing season of June, July, and August ample replenishment is required or most plant life will suffer. Crop-yield statistics for the humid and semiarid sections (see pp. 32-35) indicate that, in general, after germination, from 7 to 8 inches of favorably distributed precipitation is the minimum requirement for the production of average yields, unless temperatures are abnormally low or high, or there are excessively hot winds.

A comparison of available records of precipitation and run-off in the northeastern United States prior to $1906^{3}$ as given in table 3 indicates that in the humid areas during the growing period evaporation and plant growth will consume as much as $3 \frac{1}{2}$ inches of precipitation a month. Therefore, unless the monthly precipitation during the growing season exceeds that amount or comes so rapidly that it cannot all be consumed, there will be little water available for replenishing either the surface or the ground water.

\footnotetext{
3 See Hoyt, J. C., Comparison between rainfall and run-off in northeastern United States; Am. Soc. Civil Eng. Trans., vol. 59, paper 1061, 1907.
} 
TABLE 3.-Losses between precipitation and run-off prior to 1906 for the vinter and summer months

\begin{tabular}{|c|c|c|c|c|c|c|c|c|c|}
\hline \multirow{3}{*}{ Station } & \multicolumn{4}{|c|}{ December to April } & \multicolumn{4}{|c|}{ June, July, August } & \multirow{3}{*}{$\begin{array}{c}\text { Total } \\
\text { yearly } \\
\text { loss } \\
\text { (inches) }\end{array}$} \\
\hline & \multirow[b]{2}{*}{$\begin{array}{l}\text { Procip- } \\
\text { itation } \\
\text { (inches) }\end{array}$} & \multicolumn{2}{|c|}{ Run-off } & \multirow[b]{2}{*}{ (inches) } & \multirow[b]{2}{*}{$\begin{array}{l}\text { Precip- } \\
\text { itation } \\
\text { (inches) }\end{array}$} & \multicolumn{2}{|c|}{ Run-off } & \multirow[b]{2}{*}{$\begin{array}{l}\text { Loss } \\
\text { (inches) }\end{array}$} & \\
\hline & & Inches & $\begin{array}{l}\text { Percent } \\
\text { of prie- } \\
\text { cipita- } \\
\text { tion }\end{array}$ & & & Inches & $\begin{array}{c}\text { Percent } \\
\text { of pre- } \\
\text { cipita- } \\
\text { tion }\end{array}$ & & \\
\hline $\begin{array}{l}\text { Oonnecticut River at Or- } \\
\text { ford, N. H }\end{array}$ & 12.89 & 11.19 & 87 & 1.70 & 12.00 & 3.87 & 32 & 8.13 & 15.10 \\
\hline $\begin{array}{l}\text { Housatonic River at Gay- } \\
\text { lordsville, Conn. } \\
\text { Susquehanna River at Har- }\end{array}$ & 17.80 & 17. 12 & 96 & .68 & 16.02 & 5.12 & 32 & 10.90 & 18.43 \\
\hline River at Har- & 14.48 & 13. 58 & 94 & .90 & 12.25 & 2.85 & 23 & 9.40 & 18. 29 \\
\hline $\begin{array}{l}\text { Wilkes-Barre, Pa. } \\
\text { Susquehanna }\end{array}$ & 14.47 & 16.48 & 114 & -2.01 & 14.00 & 2.74 & 20 & 11.26 & 16.66 \\
\hline $\begin{array}{l}\text { Williamsport, Pa } \\
\text { ohio River at Wheeling, }\end{array}$ & 15.48 & 14. 76 & 95 & .72 & 12.87 & 3.30 & 26 & 9.57 & 17.76 \\
\hline $\begin{array}{l}\text { Ohlo River at Wheeling, } \\
\text { W. Va } \\
\text { Potomac River at Point of }\end{array}$ & 16.23 & 15.16 & 93 & 1.07 & 12.61 & 3.12 & 25 & 9.49 & 19.02 \\
\hline River at Mill- & 14.14 & 9.14 & 65 & 5.00 & 11.80 & 2.44 & 21 & 9.36 & 22.64 \\
\hline $\begin{array}{l}\text { ville, W. Va- } \\
\text { James River at Carters- }\end{array}$ & 14. 38 & 7.72 & 54 & 6.66 & 12.60 & 2.80 & 22 & 9.80 & 24.69 \\
\hline $\begin{array}{l}\text { ville, Va. } \\
\text { James River at Buch- }\end{array}$ & 16.95 & 10.76 & 63 & 6.19 & 13. 69 & 3.51 & 26 & 10.18 & 24.77 \\
\hline $\begin{array}{l}\text { ana } \\
\text { Nortl }\end{array}$ & 15.99 & 10.37 & 65 & 5.62 & 12.87 & 2.97 & 23 & 9.90 & 24.26 \\
\hline & 15.89 & 9.57 & 60 & 6.32 & 12.69 & 2.98 & 23 & 9.71 & 24.77 \\
\hline Va & 16. 87 & 9. 89 & 59 & 6.98 & 14.36 & 3.05 & 21 & 11.31 & 26.50 \\
\hline at & 16.50 & 9.84 & 60 & 6. 66 & 13.48 & 3. 63 & 27 & 9.85 & 24.99 \\
\hline dolph, Va & 17.53 & 9.53 & 54 & 8.00 & 14.60 & 4. 62 & 32 & 9.98 & 25. 14 \\
\hline
\end{tabular}

Surface and subsurface water supplies are usually at a minimum at the end of the growing season, which for most sections of the United States is about October 1. From that time until the beginning of the next growing season, about April 1, the losses through evaporation and plant life are comparatively small, and the precipitation is mostly available for replenishing surface and subsurface waters. For this reason October 1 may be used as the beginning of the water year in presenting stream-flow records. The major part of stream flow depends on the precipitation during the nongrowing season.

In the humid areas, where cultivated crops depend wholly on rain, there will obviously be a drought when an absence of rain occurs in the growing season. In the semiarid regions dependence on rain also makes a dry period a drought period. In the true arid country, however, where crops depend for their moisture largely on impounded water, a drought is not caused by absence of precipitation during the growing season but rather by absence of precipitation during the nongrowing seasons, as precipitation during these seasons furnishes a larger part of the water for storage.

The demand for water for natural vegetation is different from that for cultivated crops. Through the centuries the natural vegetation 
has adapted itself to its environment, so that it can withstand to a large degree absence of moisture for long periods, extremes in temperatures, and high desiccating winds. Ecologists state that this is a part of the process of "edaphic adaptation." Therefore, in a sense, natural vegetation, including arborescent flora, can survive droughts that would affect cultivated crops. The effect of a drought on such vegetation, however, may consist in lessening cellulose produced, reducing the growing season, and as a corollary increasing the dormant season.

As related to agriculture, a drought depends largely on the extent to which man has entered into the picture.

In ordinary years the humid areas have adequate precipitation to supply the needs of vegetation. Nevertheless, there may be in any year small areas in which vegetation is affected by shortages of water, and at intervals ranging from 15 to 20 years there may be major shortages that may seriously affect vegetation over large areas. The correction of these effects is largely outside the control of man, and to be successful, agricultural activities in the humid section should be so planned as to provide for carrying over these lean years.

The precipitation in the semiarid sections of the country is so small that vegetation is affected in a large measure not only by fluctuations in the total annual precipitation but also by unsatisfactory distribution throughout the year. These areas, which may be for alternate years either humid or arid, according to the precipitation, were originally natural range and produced, in the main, only vegetation for stock raising, which was successfully carried on for many years. In 1873 the Director of the United States Geological Survey, in testifying before a congressional committee on public lands, indicated that most of the country lying west of Minnesota was an arid region and in the main could not be used for agriculture except by irrigation. Five years later he reiterated this statement before another committee. While irrigation has been successfully carried on in the arid sections, unfortunately it has not been found economically feasible in most semiarid sections. The United States Weather Bureau has repeatedly expressed cautions against any great extension of agriculture in the semiarid States.

The reason for the failure to heed these warnings is shown in figures 1 and 19, which indicate that since 1880 drought years in the semiarid States have been more or less bunched, with several years of no drought between each group. The periods of no drought were 1880 to 1885,1902 to 1906 , and 1918 to 1923 . With adequate precipitation, these semiarid areas are especially adapted to the growing of wheat, and during nondrought years large areas were converted from range to wheat culture. It was this section that suffered so greatly during the drought period 1930-34, which again called attention to the ever-present danger to many types of agriculture that 
have been undertaken in the semiarid regions and have not fully succeeded. If the future is to be judged by the past, there is no indication that such activities can be continued in these areas with any assurance of success under the present methods of farming.

In the arid regions vegetation is limited both in character and in extent, except in subirrigated bottom lands and artificially irrigated areas. Successful irrigation depends primarily upon the way in which available water supplies are developed, the character of the land, and the methods of distribution and application of water. Detrimental effects of droughts on agriculture in these regions depend largely on the character and extent of farming activities.

In most irrigated areas ample water is usually available to meet present requirements if it is wisely developed and used. This fact was clearly shown during the period 1930-34, when on projects that had been properly devtloped and were scientifically operated losses due to inadequate water were generally not serious.

The marked effect that vegetation has on surface and ground water was clearly shown during the droughts of 1930 and 1931, as after light precipitation there was a noticeable increase in the flow of springs and small streams, even though no great amount of water could have been contributed. This effect was also indicated on cloudy days and during nights, when there was a slowing up of plant growth. At the end of the growing season the flow of springs and small streams increased, even though there was no precipitation, and water appeared in many springs and small streams that had been dry during the growing season.

Examples of the effect of the consumptive use of water by vegetation on water supplies in Maryland and Virginia are given in the Monthly Weather Review for October 1930. Among these observations were those of the flow of a small stream at Cabin John, Md., a suburb of Washington. The behavior of this stream, which has a drainage area of only a few acres and is in effect a spring, was typical of that of numerous other springs and small streams in Maryland and Virginia. During the summer there was a diurnal fluctuation in which the low flow was at times only one-sixth of the high flow. In September the stream became intermittent each day, but in October, although there had been no appreciable precipitation, the flow became continuous again, with diurnal fluctuations similar to those that existed before the intermittent period.

The gage-height graph (fig. 6) of the South Fork of the Mills River at The Pink Beds, N. C., which has a drainage area of 9.87 square miles, mostly wooded, indicates how diurnal fluctuations in stream flow due to transpiration and evaporation vary throughout the year. In the winter the flow is steady, the graph being almost a straight line. Through the growing season the graph shows regular diurnal fluctuations as transpiration takes its share of the supply 


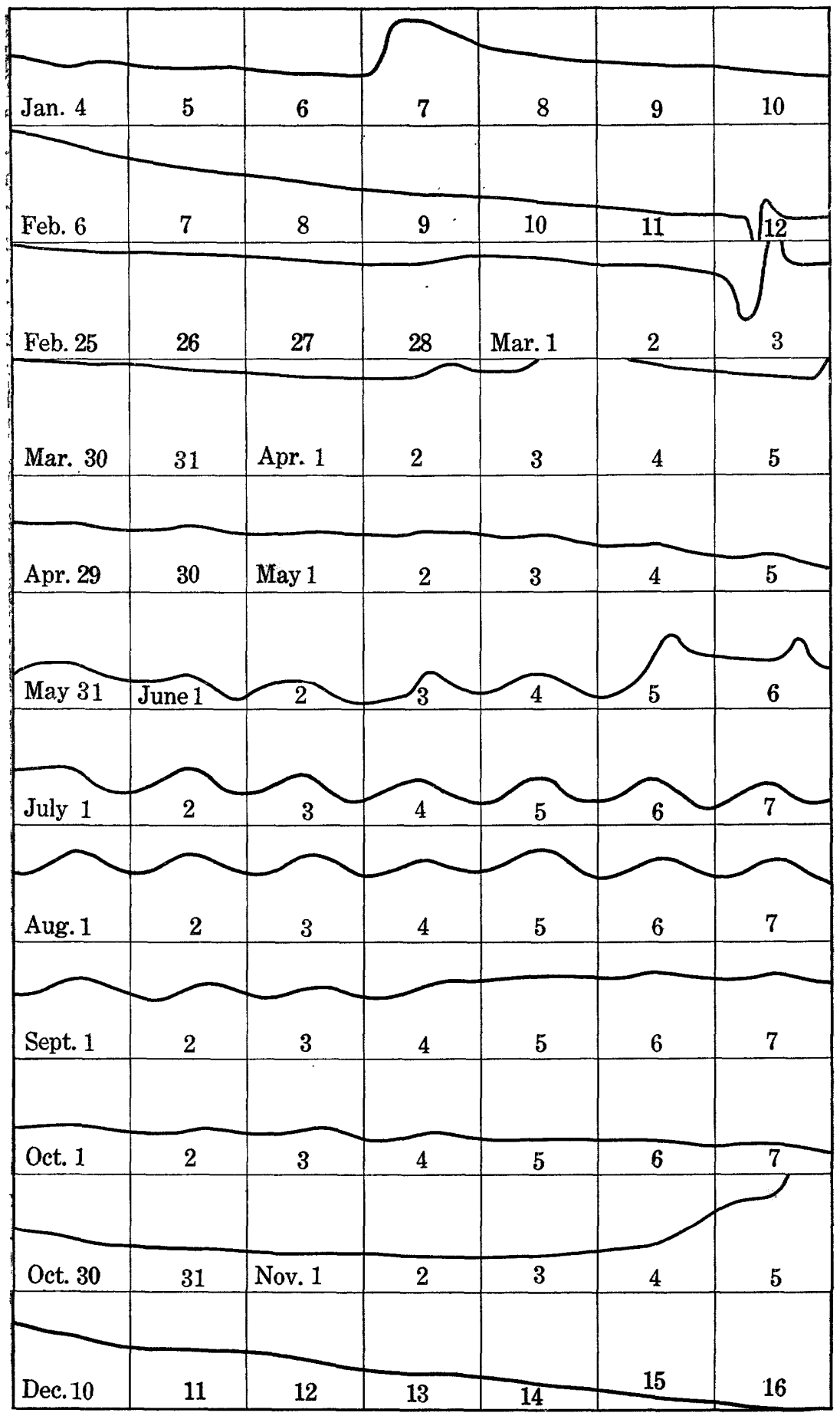


during daylight and diminishes during the night, with a lag before the effect appears in stream flow. Translated into flow, the daily variations are as large as 30 percent.

The magnitude of losses through transpiration and evaporation is illustrated by variations of flow for Owens Creek at Lantz, Md. This stream has a drainage area of 5.99 square miles, located in a wooded mountain region at an altitude of about 1,500 feet. Figure 7 shows the diurnal fluctuations in the gage height of this stream from June 1 to 5, 1932. These fluctuations, as indicated on the graph, correspond to a daily variation of flow that averages over 20 percent. and aggregates about 820,000 gallons a day, enough to furnish an average municipal supply for 8,000 people.

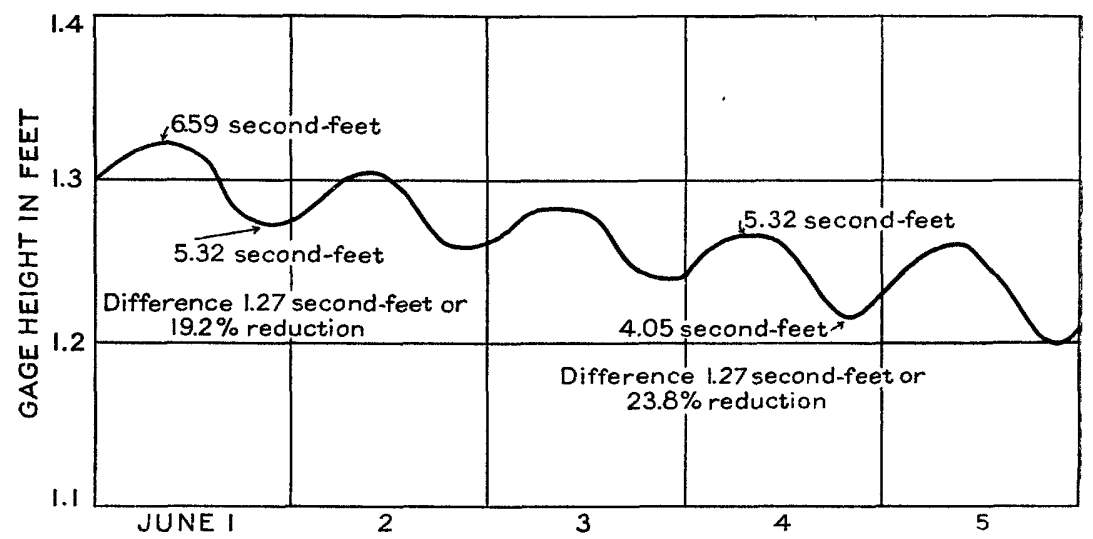

Figure 7.-Gage-height graph of Owens Creek at Lantz, Md., June 1-5, 1932, showing effect of transpiration and evaporation on stream flow.

Diurnal fluctuations in low-water flow of streams caused by daily evaporation and transpiration apparently vary inversely as the depth to the water table, as indicated in figure 8, a graph of hourly discharge over a weir on Piney Run near Sykesville, Md. (drainage area, 11 square miles), for two similar 2-day periods, both of wbich are representative of the low-water flow for their respective years. Prior to each 2-day period there had been no rainfall for a considerable length of time, so that all of the direct surface run-off from the last rains had passed out of the basin, and the stream flow as shown in the figure was derived mostly from the ground-water reservoir and therefore gives a fair indication of the depth of the water table in this small basin. The graphs indicate a marked fluctuation in flow, the high flow resulting from hours of little or no evaporation and transpiration, and the minimum flow showing the effects of the hours when transpiration and evaporation are greatest. The difference between the high and low rate of discharge for the day indicates the maximum rate at which evaporation and transpiration were depriving the stream. 
The areas in figure 8 which are enclosed between the dashed line and the graph provide a measure of the daily loss to the stream, which has been computed, as shown in the figure, in million gallons a day. No records of ground-water levels are available, but it was observed that the precipitation in 1933 was ample to maintain a higher groundwater table than in 1932, when there was less precipitation. In 1933, a year of ample rainfall and correspondingly high ground water, the low flow was about 150 percent greater on June 3 and 4 than for the same 2 days in 1932, which was a year of low rainfall and correspondingly low ground water. The estimated evaporation and transpira-

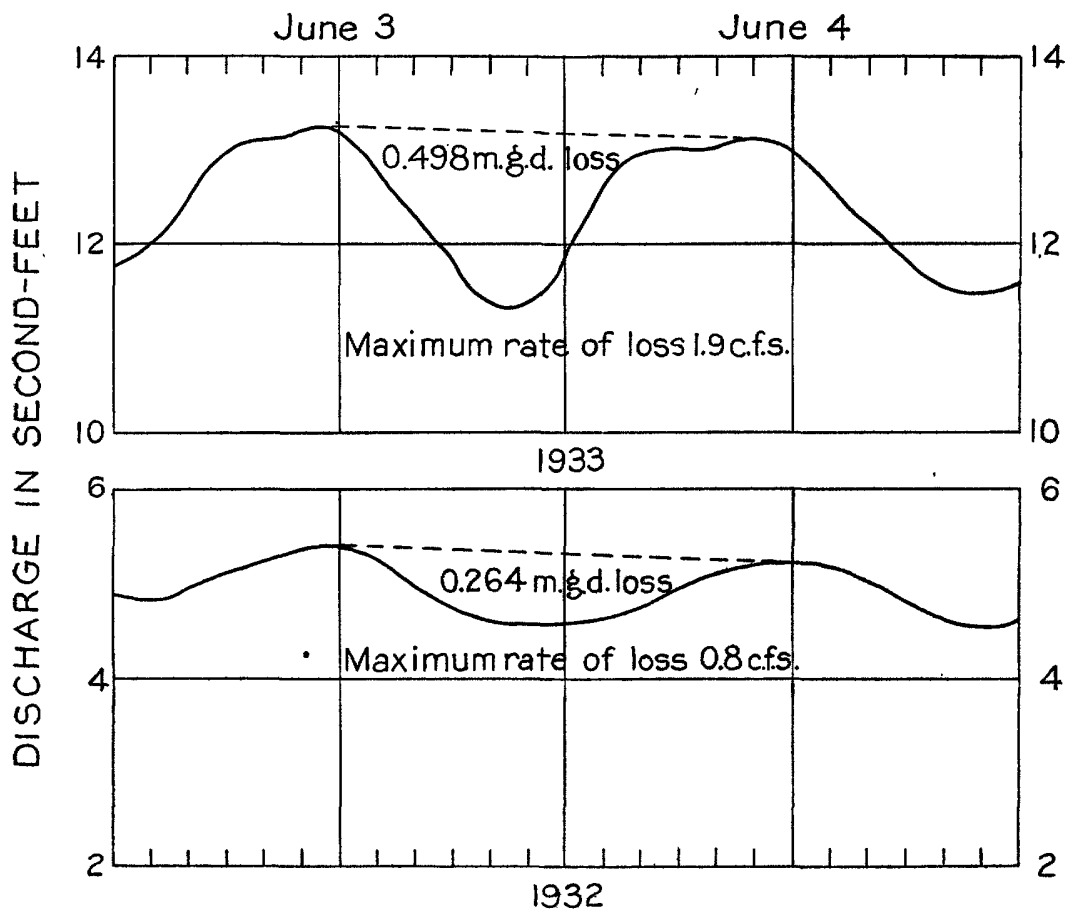

FrquRE 8.-Discharge graph of Piney Run near Sykesville, Md., showing effect of transpiration, evaporation, and altitude of water table on stream flow.

tion losses producing diurnal fluctuations in the low stream flow were about 90 percent greater in 1933 than in 1932 . The indications are that this difference was largely due to the fact that less evaporation and transpiration from ground water takes place when the water table is at a greater depth.

Evaporation from surfaces of impounded water and of flowing streams is an important factor in connection with the effect of drought on both surface and ground water. During the summer of 1930 measurements of flow of the Potomac River at Point of Rocks, Md., indicated less discharge than the combined flow as recorded at river- 
measurement stations at Shepherdstown, Millville, and other points on tributary streams above Harpers Ferry. The distance between Point of Rocks and the upper measurement stations is about $28 \%$ miles. The area of water surface in this stretch of the river is about 5.75 square miles. An evaporation of 0.01 foot for 24 hours from this area of water surface would be equivalent to a flow of 18.6 second-feet. There were many days during the summer of 1930 when the humidity was extremely low, with brisk winds, on which the evaporation probably approached 0.1 foot a day. The loss due to this evaporation was. sufficient to account for apparent discrepancies in the discharge as measured at Point of Rocks, where the minimum daily flow in 1930 was 594 second-feet, and at points on tributary streams above.

\section{GROUND WATER}

Comparatively few systematic records of fluctuations of groundwater levels have been collected, and most of these cover only short periods. Therefore any statement relative to the effect of the drought; on ground water is more qualitative than quantitative. In general, however, it is known that during 1930 and 1931 there were marked lowerings of ground-water levels, which severely affected many communities that depend on ground water for domestic and other uses, and in many localities flowing springs and wells either became intermittent or ceased to flow until the end of the drought.

An example of the effect of the drought on the ground-water table is indicated in figure 9, which shows the precipitation at Washington, D. C., and corresponding fluctuations of the water surface of the Ross well, in nearby Virginia." This graph, produced by a water-stagerecorder, shows that in the winter of 1928-29 replenishment of the ground-water supply began late in January, and in the winter of 192930 it began about the middle of January, whereas in the winter of 1930-31 it did not begin until near the end of March. In the winterof 1931-32 it began about the first of January. The winter replenishment raised the ground-water table somewhat over 2 feet in 1928-29, and in 1929-30, over 4 feet in 1931-32, and over 6 feet in 1932-33, but less than 1 foot in 1930-31.

On account of the great draw-down caused by the drought of 1930 , the water table at the site of the Ross well dropped to an extreme low stage and reached its greatest depression in March 1931. The summer of 1931 was unusually favorable for replenishment, however, and hence at the well site there was a small net rise in the water table, which was in striking contrast to the decline of about 3 feet in the summer and autumn of 1930. A rise of nearly half a foot was produced by the heavy rains that occurred at the end of May and the be-

\footnotetext{
4 Cady, R. C., Investigations of the fluctuations of water levels in observation wells in Virginia: Am. Geophys. Union Trans., 1932, pp. 370-373.
} 


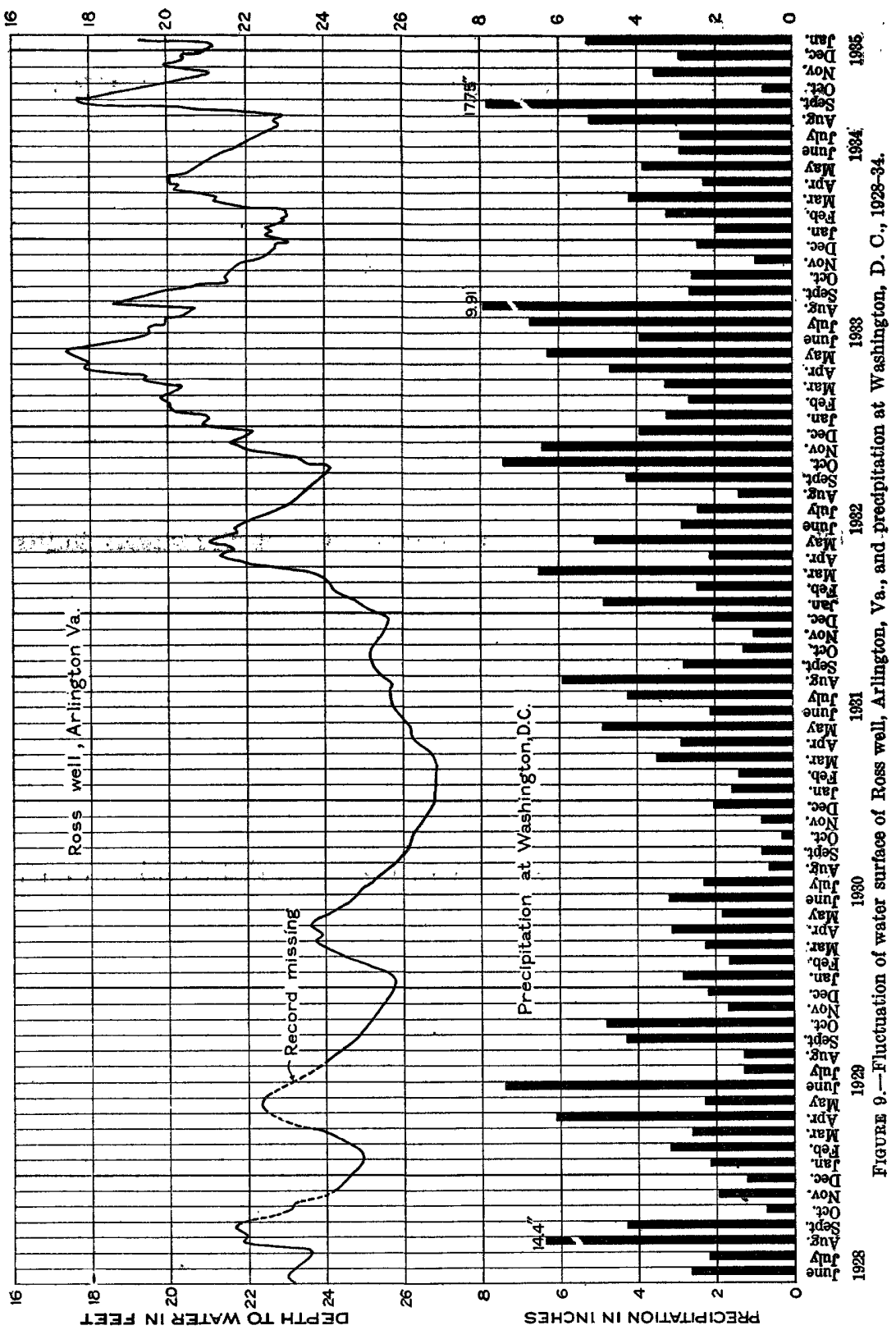


ginning of June 1931, and a further rise of about the same amount was produced by the combined effect of heavy rains in July and August. Later in the season the water level declined about to the July level. The most notable summer replenishments within the period of record occurred in August 1928, August 1933, and September 1934; in August 1928 the precipitation amounted to 14.4 inches, and the water table rose about 2 feet; in August 1933 the precipitation amounted to 9.91 inches, and the water table rose about the same amount; in September 1934, however, the precipitation was 17.45 inches, and the water table rose 5 feet.

It should be explained that in the summer of 1931 there was more replenishment at this observation well than at several other wells in Arlington and Fairfax Counties, in which measurements of the water level were made. For example, in one of these other wells the water level dropped slightly more than 1 foot from August 22 to December 26, whereas during this period the water level in the observation well first rose and then fell, with almost no net change. This was probably due to geologic conditions that were favorable to percolation.

Comparison of the Ross well records with the barograph observations at Washington indicates that the ground-water table fluctuates in response to variations in atmospheric pressure. These fluctuations have only a small range. They can, however, readily be distinguished from any rise produced by replenishment. Apparently when the soil is dry changes in atmospheric pressure are transmitted through the air-filled interstices in the soil almost as easily as through the air column in the well. Hence the changes in pressure on the water table are essentially equal to the changes in pressure on the water surface in the well. On the other hand, when the pore spaces in the soil contain more water, the barometric changes cannot be transmitted so readily to the water table as to the water surface in the well, and hence the water surface is depressed when the barometer rises and recovers when the barometer falls. In some wells that extend into water-bearing formations overlain by impervious confining beds the barometric fluctuations have been found to be nearly 100 percent of the fluctuations of a water barometer. As the locality of the observation well near Washington has a water table without any competent confining bed, the barometric fluctuations are much smaller. Thus they amounted to only about 15 percent from April 27 to May 4, 1930, when the soil moisture was fully replenished, and to a much smaller percentage from November 22 to 29,1930 , when the soil was very dry. ${ }^{5}$

\footnotetext{
- Meinzer, O. E., Methods of estimating ground-water supplies: U. S. Geol. Survey Water-Supply Paper 638, pp. 140-142, 1932 .
} 


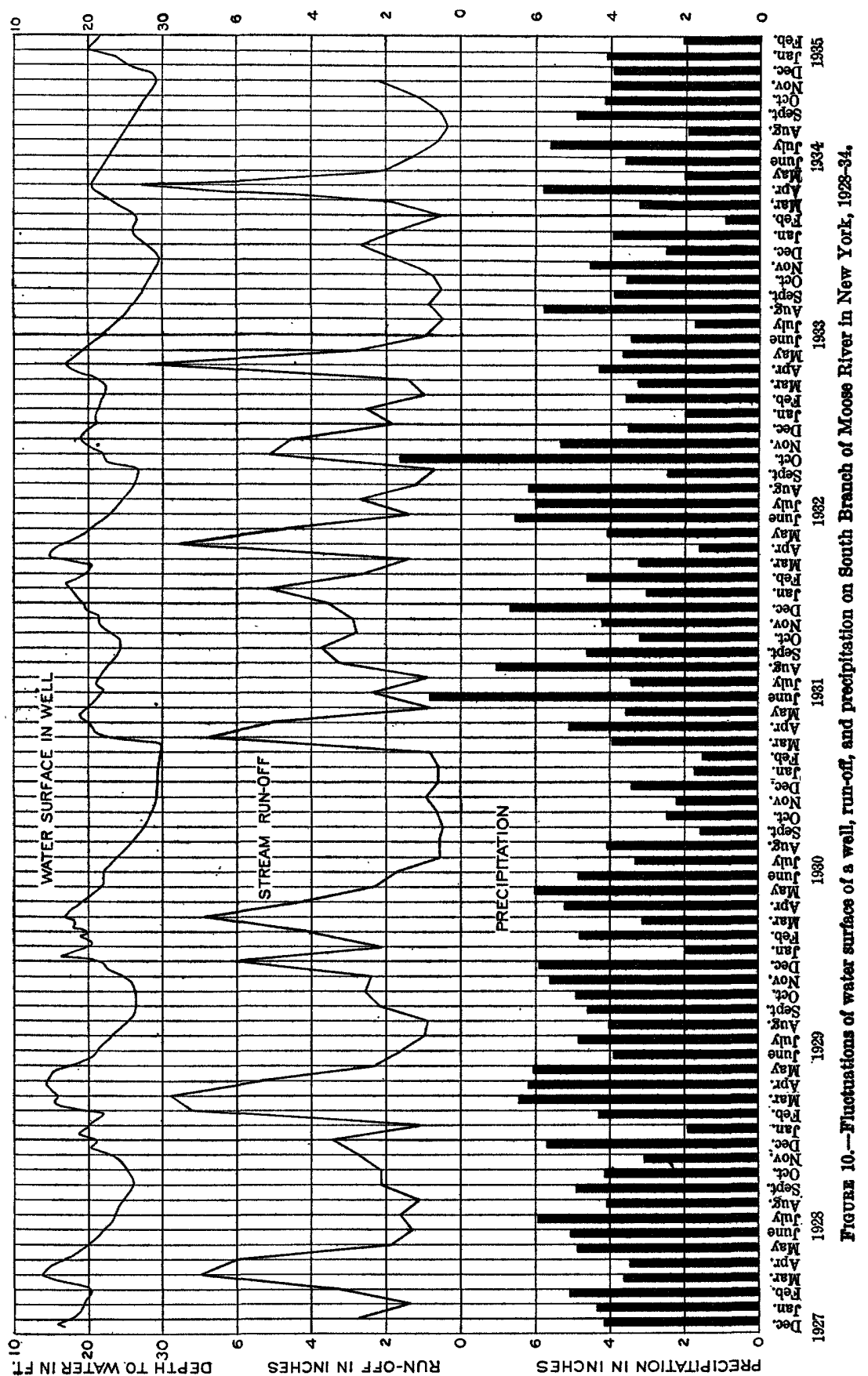


Ground-water levels recorded at White Lake Corners, Oneida County, N. Y., since 1928, are shown in figure $10 .^{\circ}$ The same diagram also shows the run-off from the South Branch of the Moose River, a nearby stream with a drainage area of 216 square miles, and the average rainfall over this area as obtained from rain gages at McKeever, North Lake, and Raquette Lake. These records, like others, show that in the main the fluctuation of both ground water and stream flow follow closely the precipitation, and there is no indication of large carry-over effects from either high or low precipitation.

The general trend of the ground-water fluctuations starting with the end of the growing season is a rise in level until January or February, when, apparently owing to frost conditions, the level falls until the spring break-up; then it rises again until the beginning of the growing season; and then, owing to the demands for water by vegetation, it drops until the end of the growing season.

Prior to the beginning of the drought of 1930 the precipitation and corresponding ground-water level and also the stream flow were average or above. In spite of the severity of the drought both the stream flow and the ground-water levels responded almost immediately to the increased precipitation late in 1931, and continued on an upward trend until the beginning of the growing season of 1932, when they were not materially lower than at the corresponding dates in 1928 and 1929.

\section{SURFACE WATER}

Surface waters in lakes, ponds, reservoirs, and flowing streams were severely depleted as a result of the droughts of 1930 and 1931 . There was a material lowering of the surface of bodies of impounded water. Many reservoirs were drained entirely, the surfaces of larger lakes and ponds were materially lowered, and many of the smaller ones practically dried up. Many new minima for the flow of streams were established during the calendar years 1930 and 1931. In general, however, the minimum daily flows did not fall much below those previously recorded. On the other hand, the weekly and monthly flows for many streams reached new minima, and many records of long-continued low flows were broken.

During 1930 minimum flows for the period of record were reached on many streams as early as July, and the flow did not go much lower while the drought lasted. The drought continued long enough in most drainage basins to test available ground-water supplies thoroughly, and the records indicated that the available ground-water supply for some basins may be so great that it is adequate to maintain the stream flow above a fixed minimum for a considerable length of time and probably through most droughts.

- Unpublished data furnished by Edwin S. Cullings, member Am. Soc. Civil Eng., Watertown, N. Y. 
The records of stream flow indicate that the small variations in flow during low-water periods, caused by occasional rains, are of short duration, as shown in table 4, which gives the daily flow of the Potomac River at Shepherdstown, W. Va., during the last 7 months. of 1930. The effect of the drought on stream flow started late in June, was well established by July 11, and continued until December 27. A minimum flow of 300 second-feet was recorded on one day each in July and August. In September the flow was between 330 and 340 second-feet on several days, in October it was 307 secondfeet on 4 days, in November it was 325 second-feet on 2 days, and in December it was 371 second-feet on 3 days.

TABLE 4.-Daily discharge, in second-feet, of Potomac River at Shepherdstown, W. Va., June 1 to Dec. 31,1930

[Drainage area, $\mathbf{5 , 9 7 0}$ square miles]

\begin{tabular}{|c|c|c|c|c|c|c|c|}
\hline Day & June & July & Aug. & Sept. & Oct. & Nov. & Dec. \\
\hline 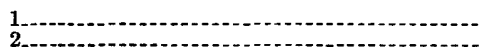 & 1,080 & 1,130 & 554 & 428 & 371 & 325 & 401 \\
\hline (3.). & $\begin{array}{l}1,000 \\
1,000\end{array}$ & $\begin{array}{r}1,050 \\
918\end{array}$ & $\begin{array}{l}384 \\
320\end{array}$ & $\begin{array}{l}489 \\
428\end{array}$ & $\begin{array}{l}371 \\
371\end{array}$ & $\begin{array}{l}334 \\
334\end{array}$ & $\begin{array}{l}381 \\
371\end{array}$ \\
\hline 5 & $\begin{array}{r}1,000 \\
931\end{array}$ & $\begin{array}{l}780 \\
780\end{array}$ & $\begin{array}{l}450 \\
825\end{array}$ & $\begin{array}{l}450 \\
417\end{array}$ & $\begin{array}{l}381 \\
371\end{array}$ & $\begin{array}{l}343 \\
343\end{array}$ & $\begin{array}{l}371 \\
371\end{array}$ \\
\hline$\cdots$ & 931 & 825 & 855 & 406 & 381 & 361 & 391. \\
\hline$\cdots$ & 1,040 & 825 & 636 & 395 & 381 & 381 & 431 \\
\hline$\cdots$ & $\begin{array}{l}821 \\
917\end{array}$ & $\begin{array}{l}825 \\
580\end{array}$ & $\begin{array}{l}541 \\
463\end{array}$ & $\begin{array}{l}395 \\
384\end{array}$ & $\begin{array}{l}391 \\
381\end{array}$ & $\begin{array}{l}381 \\
381\end{array}$ & $\begin{array}{l}834 . \\
391\end{array}$ \\
\hline $10 \ldots$ & 931 & 855 & 406 & 373 & 371 & 381 & 656 \\
\hline 11 12 & $\begin{array}{r}945 \\
1,320\end{array}$ & $\begin{array}{l}489 \\
489\end{array}$ & $\begin{array}{l}373 \\
362\end{array}$ & $\begin{array}{r}-351 \\
340\end{array}$ & $\begin{array}{l}371 \\
371\end{array}$ & $\begin{array}{l}381 \\
391\end{array}$ & $\begin{array}{l}692 \\
889\end{array}$ \\
\hline - & 3,750 & 384 & 362 & 340 & 371 & 401 & 903. \\
\hline 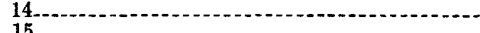 & 2,870 & 463 & 351 & 340 & 371 & 421 & 808 \\
\hline - & 2,160 & 594 & & 340 & 371 & 421 & \\
\hline $16-\ldots \ldots . .$. & 1,760 & 692 & 300 & 340 & 352 & 451 & 743. \\
\hline 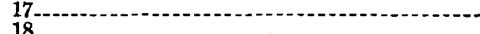 & $\begin{array}{l}1,730 \\
1,730\end{array}$ & $\begin{array}{l}594 \\
489\end{array}$ & $\begin{array}{l}310 \\
310\end{array}$ & $\begin{array}{l}351 \\
330\end{array}$ & $\begin{array}{l}352 \\
343\end{array}$ & 8211 & 494 \\
\hline $\begin{array}{l}18 \ldots \ldots \\
19 \ldots\end{array}$ & $\begin{array}{l}1,730 \\
1,690\end{array}$ & $\begin{array}{l}489 \\
439\end{array}$ & $\begin{array}{l}310 \\
310\end{array}$ & $\begin{array}{l}000 \\
340\end{array}$ & $\begin{array}{l}343 \\
343\end{array}$ & $\begin{array}{l}{ }_{431}^{644} \\
-\end{array}$ & $\begin{array}{l}472 \\
717\end{array}$ \\
\hline $20 \ldots$ & 1,630 & 351 & 330 & 351 & 334 & 411 & 717 \\
\hline L-_-........ & 1,540 & 528 & $\begin{array}{l}384 \\
384\end{array}$ & $\begin{array}{l}351 \\
362\end{array}$ & $\begin{array}{l}343 \\
361\end{array}$ & 381 & $\begin{array}{l}483: \\
692\end{array}$ \\
\hline (1....... & $\begin{array}{l}1,120 \\
1,210\end{array}$ & $\begin{array}{l}594 \\
608\end{array}$ & $\begin{array}{l}384 \\
362\end{array}$ & $\begin{array}{l}362 \\
450\end{array}$ & $\begin{array}{l}361 \\
334\end{array}$ & 325 & $\begin{array}{l}694 \\
644\end{array}$ \\
\hline $24 \ldots$ & 1,090 & 594 & 406 & 401 & 316 & 343 & 527 \\
\hline $25 \ldots$ & 1,100 & 706 & 439 & 371 & 307 & 334 & 431 \\
\hline $26-\ldots$ & 1,360 & 300 & 450 & 371 & 316 & 361 & 483 \\
\hline $27-$ & $\begin{array}{l}1,530 \\
973\end{array}$ & $\begin{array}{l}340 \\
502\end{array}$ & $\begin{array}{l}439 \\
428\end{array}$ & $\begin{array}{l}352 \\
352\end{array}$ & $\begin{array}{l}307 \\
307\end{array}$ & $\begin{array}{l}352 \\
352\end{array}$ & $\begin{array}{c}959 \\
931\end{array}$ \\
\hline 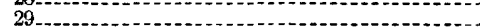 & 987 & 567 & 417 & 361 & 307 & 361 & 808 \\
\hline $\tan (-5)$ & 1,310 & 515 & 406 & 371 & 316 & 361 & 861 \\
\hline (1)....... & & 528 & 417 & & 325 & & \\
\hline Mean_-.. & 1,380 & 624 & 429 & 378 & 351 & 395 & 621 \\
\hline
\end{tabular}

The combined flow from the Tennessee and Cumberland River drainage basins ${ }^{7}$ as compared with the precipitation in the same area for the 30-year period 1900-29 is shown in figure 11. For this 30-year period the average run-off was 45 percent of the precipitation. In wet years it exceeded 50 percent, and in dry years it dropped to 35 percent or less, indicating that the losses through evaporation and

' See King, W. R., Surface waters of Tennessee: Tennessee Dept. Education Bull. 40, p. 56, 1931. 
transpiration do not vary materially between wet and dry years as long as there is sufficient precipitation to satisfy the evaporation and transpiration demands, and that deficiency in rainfall may mean a relatively greater deficiency in stream flow. This is important in planning municipal water supplies.

A wide variation in the unit run-off of different areas is found, even in areas adjacent to each other. Observations in 1930 showed that some streams became dry while others of comparable size in adjacent basins continued through the drought with a fair discharge. As conditions in different drainage basins vary, estimates of low flow

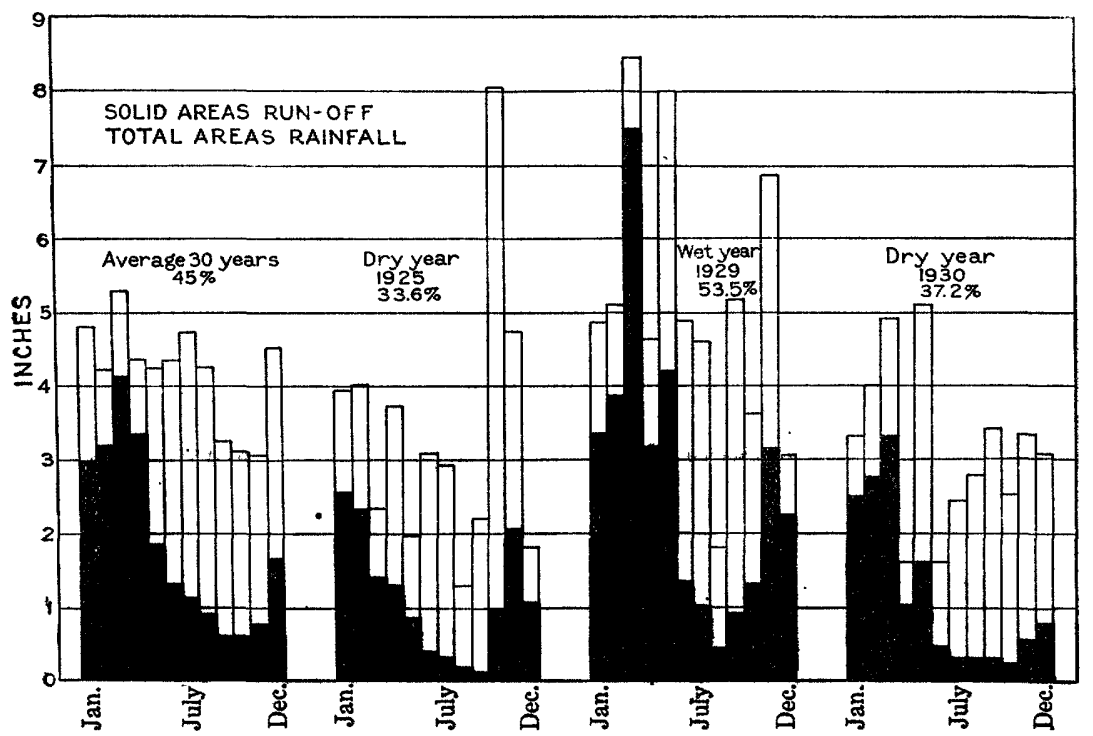

FIGURE 11.-Rainfall and run-off for combined drainage basins of Tennessee and Cumberland Rivers, by months, showing variation between wet and dry years. Ratio of run-off to rainfall is indicated in percent on diagram.

based on comparison with adjacent areas or on precipitation data cannot be made with any degree of certainty. Records of flow on the stream that is to be utilized afford the only safe basis for making studies in connection with a given development. Records of daily flow are essential for detailed studies, but for general comparative studies records of mean monthly flow and deficiency tables will serve many needs. Such data for the Potomac River at Point of Rocks, $\mathrm{Md}$., are presented in tables 5 and 6 as typical records showing the general effect of the droughts of 1930 and 1931 on stream flow. 
TABLI 5.-Monthly and yearly discharge, in second-feet, of Potomac River at Point of Rocks, Md., 1895-1981

[Drainage area, 9,650 square miles]

\begin{tabular}{|c|c|c|c|c|c|c|c|c|c|c|c|c|c|}
\hline Year & Jan. & Feb. & Mar. & Apr. & May & June & July & Aug. & Sెept. & Oct. & Nov. & Dec. & $\begin{array}{l}\text { Yearly } \\
\text { average }\end{array}$ \\
\hline & & & 24,560 & 14,500 & 12,540 & 3,910 & 4,462 & 1,997 & 1,565 & 1,163 & 1,333 & 2,259 & - \\
\hline & & 470 & $850 !$ & 10.830 & 050 & $\begin{array}{l}429 \\
897\end{array}$ & & 3,449 & 2,185 & & 6,928 & 4,723 & היחק \\
\hline 1899 & $\left|\begin{array}{r}4,284 \\
14,660 \\
18,680\end{array}\right|$ & $\left|\begin{array}{r}42,660 \\
8,339 \\
28,130\end{array}\right|$ & $\left|\begin{array}{l}20,850 \\
15,330 \\
35,240\end{array}\right|$ & $\mid \begin{array}{l}10,850 \\
15,970 \\
11,750\end{array}$ & $\begin{array}{l}22,950 \\
18,060 \\
11,600\end{array}$ & $\begin{array}{l}5, \mathbf{9 9 7} \\
\mathbf{4}, \mathbf{1 7 8} \\
\mathbf{5 , 3 1 4}\end{array}$ & $\begin{array}{l}5,315 \\
2,418 \\
2,519\end{array}$ & $\begin{array}{r}4,092 \\
22,140 \\
2,335\end{array}$ & $\begin{array}{l}2,337 \\
2,497 \\
2,345\end{array}$ & $\begin{array}{r}1,968 \\
13,670 \\
1,663\end{array}$ & $\left|\begin{array}{l}2,096 \\
8,557 \\
3,171\end{array}\right|$ & $\begin{array}{r}6,579 \\
15,330 \\
4,068\end{array}$ & $\begin{array}{l}10,800 \\
11,800 \\
10,600\end{array}$ \\
\hline $\begin{array}{l}1900 \\
1901 \\
1902 \\
1903= \\
1904\end{array}$ & $\begin{array}{r}8,166 \\
4,950 \\
17,520 \\
17,200 \\
7,287\end{array}$ & $\begin{array}{r}13,340 \\
3,649 \\
32,520 \\
22,190 \\
17,480\end{array}$ & $\begin{array}{l}18,470 \\
13,800 \\
54,260 \\
26,730 \\
11,170\end{array}$ & $\mid \begin{array}{r}9,295 \\
39,750 \\
28,760 \\
28,900 \\
7,406\end{array}$ & $\begin{array}{r}4,466 \\
26,920 \\
5,973 \\
6,212 \\
9,362\end{array}$ & $\begin{array}{r}8,394 \\
19,180 \\
3,186 \\
17,970 \\
10,160\end{array}$ & $\begin{array}{r}3,008 \\
10,720 \\
3,086 \\
12,760 \\
4,510\end{array}$ & $\begin{array}{l}1,917 \\
8,337 \\
2,464 \\
4,826 \\
2,394\end{array}$ & $\begin{array}{l}1,344 \\
7,636 \\
1,490 \\
4,669 \\
1,592\end{array}$ & \begin{tabular}{|l}
1,333 \\
4,303 \\
2,767 \\
3,212 \\
1,164
\end{tabular} & $\begin{array}{l}4,570 \\
4,648 \\
2,837 \\
2,175 \\
1,340\end{array}$ & $\begin{array}{r}6,218 \\
25,610 \\
18,590 \\
2,926 \\
2,201\end{array}$ & $\begin{array}{r}6,710 \\
14,100 \\
14,500 \\
12,500 \\
6,340\end{array}$ \\
\hline $\begin{array}{l}1905 \\
1906 \\
1907 \\
1908 \\
1909\end{array}$ & $\begin{array}{r}8,626 \\
14,990 \\
27,000 \\
25,400 \\
6,950\end{array}$ & $\begin{array}{r}5,625 \\
5,116 \\
9,560 \\
24,100 \\
11,300\end{array}$ & $\begin{array}{r}23,480 \\
15,900 \\
30,500 \\
28,600 \\
8,700\end{array}$ & $\begin{array}{r}6,581 \\
22,440 \\
14,900 \\
10,200 \\
16,700\end{array}$ & $\begin{array}{r}4,493 \\
5,538 \\
11,100 \\
32,100 \\
8,660\end{array}$ & $\begin{array}{r}6,979 \\
7,007 \\
23,200 \\
7,250 \\
11,000\end{array}$ & $\begin{array}{r}10,190 \\
4,381 \\
6,010 \\
4,470 \\
2,700\end{array}$ & $\begin{array}{r}5,830 \\
15,200 \\
3,710 \\
3,880 \\
2,110\end{array}$ & $\begin{array}{l}3,205 \\
4,275 \\
6,430 \\
2,500 \\
1,780\end{array}$ & $\begin{array}{r}2,888 \\
16,310 \\
3,550 \\
2,780 \\
2,190\end{array}$ & $\begin{array}{l}2,267 \\
6,341 \\
7,850 \\
2,670 \\
1,850\end{array}$ & $\left|\begin{array}{r}10,640 \\
11,100 \\
17,800 \\
2,440 \\
3,130\end{array}\right|$ & $\begin{array}{r}7,570 \\
10,700 \\
13,500 \\
12,200 \\
6,420\end{array}$ \\
\hline $\begin{array}{l}1910 \\
1911 \\
1912 \\
1913 \\
1914\end{array}$ & $\begin{array}{r}11,700 \\
12,200 \\
9,450 \\
11,700 \\
20,000\end{array}$ & $\begin{array}{r}13,800 \\
11,300 \\
16,400 \\
5,890 \\
15,900\end{array}$ & $\begin{array}{r}9,960 \\
9,670 \\
28,700 \\
18,200 \\
19,300\end{array}$ & $\begin{array}{l}10,100 \\
15,100 \\
14,900 \\
16,100 \\
20,900\end{array}$ & $\begin{array}{r}5,520 \\
4,330 \\
19,800 \\
13,600 \\
9,600\end{array}$ & $\begin{array}{r}26,400 \\
3,690 \\
5,280 \\
10,400 \\
3,190\end{array}$ & $\begin{array}{l}5,500 \\
2,160 \\
8,550 \\
4,490 \\
3,020\end{array}$ & $\begin{array}{l}2,000 \\
2,440 \\
3,460 \\
3,010 \\
1,750\end{array}$ & $\begin{array}{r}1,740 \\
12,600 \\
6,360 \\
1,770 \\
1,270\end{array}$ & $\begin{array}{l}1,560 \\
8,510 \\
3,090 \\
6,850 \\
1,400\end{array}$ & $\begin{array}{r}1,440 \\
\mathbf{5}, 970 \\
3,270 \\
13,500 \\
\mathbf{1}, 540\end{array}$ & $\begin{array}{r}2,090 \\
10,200 \\
3,390 \\
8,120 \\
6,000\end{array}$ & $\begin{array}{r}7,650 \\
8,180 \\
10,200 \\
9,470 \\
8,660\end{array}$ \\
\hline $\begin{array}{l}1915 . \\
1916 . \\
1917 \\
1918 .\end{array}$ & $\begin{array}{r}28,600 \\
12,500 \\
9,170 \\
2,500 \\
14,800\end{array}$ & $\begin{array}{r}27,000 \\
15,600 \\
7,630 \\
28,300 \\
5,980\end{array}$ & $\begin{array}{r}8,230 \\
24,700 \\
38,400 \\
13,600 \\
12,700\end{array} \mid$ & $\begin{array}{r}4,370 \\
19,800 \\
10,700 \\
39,800 \\
8,860\end{array}$ & $\begin{array}{r}5,900 \\
7,950 \\
5,590 \\
5,990 \\
18,300\end{array}$ & $\begin{array}{r}20,400 \\
14,000 \\
7,870 \\
3,310 \\
7,130\end{array}$ & $\begin{array}{l}2,670 \\
7,170 \\
3,890 \\
3,360 \\
7,220\end{array}$ & $\begin{array}{l}6,760 \\
3,600 \\
2,620 \\
2,910 \\
3,130\end{array}$ & $\begin{array}{r}5,350 \\
2,330 \\
1,380 \\
3,940 \\
1,720\end{array}$ & $\begin{array}{l}\mathbf{6}, 730 \\
\mathbf{2}, 190 \\
4,770 \\
1,710 \\
\mathbf{2 , 4 2 0}\end{array}$ & $\begin{array}{l}3,590 \\
1,550 \\
3,830 \\
5,610 \\
4,620\end{array}$ & $\begin{array}{r}6,650 \\
3,250 \\
2,550 \\
13,000 \\
6,880\end{array}$ & $\begin{array}{r}10,500 \\
9,550 \\
8,200 \\
10,300 \\
7,810\end{array}$ \\
\hline $\begin{array}{l}1920 \\
1921 \\
1922 \\
1923 \\
1924\end{array}$ & $\mid \begin{array}{r}10,800 \\
6,360 \\
8,110 \\
6,780 \\
18,700\end{array}$ & $\begin{array}{r}18,200 \\
6,170 \\
17,500 \\
12,500 \\
8,170\end{array}$ & $\mid \begin{array}{l}32,300 \\
12,900 \\
21,600 \\
10,700 \\
33,800\end{array}$ & $\begin{array}{r}14,500 \\
4,940 \\
9,120 \\
10,300 \\
21,000\end{array}$ & $\begin{array}{r}8,700 \\
20,700 \\
9,710 \\
5,420 \\
42,000\end{array}$ & $\begin{array}{r}8,550 \\
4,150 \\
6,660 \\
2,510 \\
14,400\end{array}$ & $\begin{array}{l}3,790 \\
4,260 \\
4,400 \\
1,560 \\
8,960\end{array}$ & $\begin{array}{l}7,150 \\
3,910 \\
2,080 \\
2,860 \\
3,120\end{array}$ & $\begin{array}{l}4,960 \\
3,650 \\
1,760 \\
3,770 \\
2,680\end{array}$ & $\begin{array}{l}2,720 \\
1,750 \\
1,270 \\
1,040 \\
7,100\end{array}$ & $\begin{array}{r}4.780 \\
4,400 \\
989 \\
2,030 \\
3,810\end{array}$ & $\begin{array}{r}9,500 \\
11,300 \\
2,340 \\
6,880 \\
4,680\end{array}$ & $\begin{array}{r}10,500 \\
7,040 \\
7,130 \\
5,530 \\
14,000\end{array}$ \\
\hline $\begin{array}{l}1925 \\
1926 \\
1927 \\
1928 \\
1929\end{array}$ & $\mid \begin{array}{r}10,400 \\
9,210 \\
10,700 \\
6,100 \\
4,620\end{array}$ & $\begin{array}{r}23,600 \\
23,000 \\
21,600 \\
10,700 \\
8,030\end{array}$ & $\begin{array}{r}9,680 \\
10,800 \\
14,500 \\
14,200 \\
24,600\end{array}$ & $\begin{array}{r}5,990 \\
11,500 \\
23,200 \\
21,200 \\
27,400\end{array}$ & $\begin{array}{r}11,300 \\
4,550 \\
14,000 \\
21,600 \\
14,700\end{array}$ & $\begin{array}{r}2,710 \\
2,640 \\
9,420 \\
16,100 \\
7,070\end{array}$ & $\begin{array}{l}2,420 \\
2,650 \\
3,210 \\
9,560 \\
3,920\end{array}$ & $\begin{array}{l}1,580 \\
9,600 \\
3,110 \\
6,240 \\
1,500\end{array}$ & $\begin{array}{r}952 \\
\mathbf{8}, 200 \\
1,540 \\
\mathbf{5}, 770 \\
1,500\end{array}$ & $\begin{array}{r}2,760 \\
6,570 \\
12,400 \\
2,750 \\
15,200\end{array}$ & $\begin{array}{r}6,820 \\
18,100 \\
8,400 \\
1,930 \\
13,000\end{array}$ & $\begin{array}{r}5,290 \\
12,900 \\
11,800 \\
4,600 \\
7,430\end{array}$ & $\begin{array}{r}6,960 \\
9,980 \\
11,100 \\
10,100 \\
10,700\end{array}$ \\
\hline 1930 & $\begin{array}{l}6,880 \\
2,370\end{array}$ & $\left|\begin{array}{l}8,970 \\
2,930\end{array}\right|$ & $\begin{array}{r}10,900 \\
5,400\end{array}$ & $\mid \begin{array}{r}7,530 \\
14,200\end{array}$ & $\begin{array}{r}3,280 \\
14,200\end{array}$ & $\begin{array}{l}2,230 \\
5,610\end{array}$ & $\begin{array}{l}1,100 \\
5,520\end{array}$ & $\begin{array}{r}771 \\
3,630\end{array}$ & $\begin{array}{r}834 \\
2,060\end{array}$ & $\begin{array}{r}706 \\
1,240\end{array}$ & $\begin{array}{l}840 \\
944\end{array}$ & $\begin{array}{l}1,420 \\
2,330\end{array}$ & $\begin{array}{l}3,790 \\
5,040\end{array}$ \\
\hline $\begin{array}{l}\text { Minimum } \\
\text { Minimum year.. }\end{array}$ & $\begin{array}{l}2,370 \\
1931\end{array}$ & $\begin{array}{l}2,930 \\
1931\end{array}$ & $\begin{array}{l}5,400 \\
1931\end{array}$ & $\begin{array}{l}4,370 \\
1915\end{array}$ & $\begin{array}{l}3,280 \\
1930\end{array}$ & $\begin{array}{l}2,230 \\
1930\end{array}$ & $\begin{array}{l}1,100 \\
1930\end{array}$ & $\begin{array}{r}771 \\
1930\end{array}$ & $\begin{array}{r}834 \\
1930\end{array}$ & $\begin{array}{c}: 706 \\
1930\end{array}$ & $\begin{array}{r}840 \\
1930\end{array}$ & $\begin{array}{l}1,420 \\
1930\end{array}$ & $\begin{array}{l}3,790 \\
1930\end{array}$ \\
\hline
\end{tabular}

NoTE.-Minimum monthly discharge for all months except April occurred in the 11 consecutive month s May 1930 to March 1931.

The conditions on the Potomac River apply in general to the areas which were most severely affected by the droughts of 1930 and 1931 . At Point of Rocks, Md., the drainage area is 9,650 square miles, and the mean flow for the calendar years 1897 to 1931 was 9,350 secondfeet. The mean flow for 1930 was 3,790 second-feet, or only 69 percent of the previous lowest annual flow, which was 5,530 secondfeet, in 1923.

Prior to 1930 there were only 2 months when the mean flow was below 1,000 second-feet-September 1925, 952 second-feet, and November 1922, 989 second-feet. During the calendar year 1930 the mean flow was below 1,000 second-feet for 4 months-August, 771; September, 834; October, 706; November, 840. The minimum daily flow for 1930 was 594 second-feet. Previous minima below 700 second-feet were recorded in 1911, 1914, 1917, and 1923. In 1923 
the flow was below 1,000 serond-feet consecutively for 18 days, in 1925 for 15 days, and in 1930 for 116 days except on 2 days when it did not exceed 1,100 second-feet. During the period of record the minimum monthly discharge for all months except April occurred in the 11 consecutive months, May 1930 to March 1931.

TABLE 6.-Deficiency table for Potomac River at Point of Rocks, Md., 1897-1981

\begin{tabular}{|c|c|c|c|c|c|c|c|c|c|c|c|}
\hline \multirow{2}{*}{$\begin{array}{l}\text { Calendar } \\
\text { year }\end{array}$} & \multicolumn{11}{|c|}{ Number of days with discharge, in second-feet, less than- } \\
\hline & 550 & 610 & 700 & 800 & 1,000 & 1,300 & 1,600 & 2,000 & 2,500 & 3,100 & 3,800 \\
\hline $\begin{array}{l}1897 \\
1898 \\
1899 \\
1900 \\
1901\end{array}$ & & 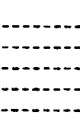 & & & & 39 & $\begin{array}{r}9 \\
6 \\
23 \\
101 \\
-.\end{array}$ & $\begin{array}{r}29 \\
8 \\
50 \\
110 \\
2\end{array}$ & $\begin{array}{r}73 \\
46 \\
115 \\
129 \\
15\end{array}$ & $\begin{array}{r}107 \\
71 \\
152 \\
152 \\
60\end{array}$ & $\begin{array}{r}137 \\
95 \\
172 \\
173 \\
88\end{array}$ \\
\hline $\begin{array}{l}1902 \\
1903 \\
1904 \\
1905 \\
1906\end{array}$ & & $\cdots$ & $\mid$\begin{tabular}{l}
$-\cdots$ \\
\hdashline- \\
\hdashline-
\end{tabular} & & $\ldots$ & $\begin{array}{r}12 \\
58 \\
-\end{array}$ & 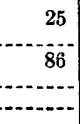 & $\begin{array}{r}51 \\
52 \\
107 \\
14 \\
\hdashline-.\end{array}$ & $\begin{array}{r}97 \\
60 \\
132 \\
37 \\
-.-\end{array}$ & $\begin{array}{r}124 \\
86 \\
150 \\
62 \\
17\end{array}$ & $\begin{array}{r}162 \\
113 \\
196 \\
130 \\
59\end{array}$ \\
\hline $\begin{array}{l}1907-\ldots-\ldots \\
1908 \\
1909 \\
1910 \\
911\end{array}$ & & & 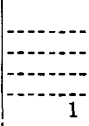 & & $\begin{array}{c}-.- \\
1 \\
1\end{array}$ & $\begin{array}{r}7 \\
16\end{array}$ & $\begin{array}{r}5 \\
25 \\
64 \\
24\end{array}$ & $\begin{array}{r}15 \\
112 \\
121 \\
40\end{array}$ & $\begin{array}{r}2 \\
58 \\
132 \\
147 \\
51\end{array}$ & $\begin{array}{r}15 \\
110 \\
163 \\
175 \\
83\end{array}$ & $\begin{array}{r}57 \\
150 \\
178 \\
198 \\
109\end{array}$ \\
\hline $\begin{array}{l}1912 \\
1913 \\
1914 \\
1915\end{array}$ & $\cdots$ & $-\cdots$ & $\cdots$ & \begin{tabular}{r|}
1 \\
12 \\
\hdashline-
\end{tabular} & $\begin{array}{r}1 \\
28 \\
2\end{array}$ & $\begin{array}{r}4 \\
63 \\
1 \\
13\end{array}$ & $\begin{array}{r}-17 \\
83 \\
3 \\
30\end{array}$ & $\begin{array}{r}8 \\
29 \\
110 \\
6 \\
65\end{array}$ & \begin{tabular}{r|}
42 \\
42 \\
133 \\
22 \\
92
\end{tabular} & $\begin{array}{r}91 \\
69 \\
166 \\
72 \\
134\end{array}$ & $\begin{array}{r}121 \\
107 \\
191 \\
99 \\
148\end{array}$ \\
\hline $\begin{array}{l}1917 \ldots \ldots . . \\
1918 \ldots 19 \\
1920 \\
1921\end{array}$ & & & 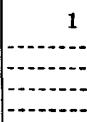 & \begin{tabular}{c}
2 \\
$\cdots$ \\
\hdashline- \\
\hdashline- \\
\hdashline-
\end{tabular} & \begin{tabular}{c}
6 \\
\\
\\
\hdashline
\end{tabular} & $\begin{array}{r}24 \\
6 \\
9 \\
6\end{array}$ & $\begin{array}{r}45 \\
15 \\
26 \\
4 \\
25\end{array}$ & $\begin{array}{l}67 \\
27 \\
48 \\
33 \\
47\end{array}$ & $\begin{array}{l}94 \\
47 \\
59 \\
45 \\
64\end{array}$ & $\begin{array}{r}126 \\
144 \\
87 \\
75 \\
96\end{array}$ & $\begin{array}{r}167 \\
183 \\
113 \\
94 \\
116\end{array}$ \\
\hline $\begin{array}{l}1922 \\
1923 \\
1924 \\
1925 \\
1926\end{array}$ & 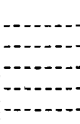 & & $\overline{1}$ & $\begin{array}{r}3 \\
12\end{array}$ & $\begin{array}{l}43 \\
23 \\
-21\end{array}$ & $\begin{array}{r}67 \\
38 \\
42\end{array}$ & $\begin{array}{r}78 \\
68 \\
3 \\
63 \\
7\end{array}$ & $\begin{array}{r}110 \\
102 \\
17 \\
89 \\
20\end{array}$ & $\begin{array}{r}131 \\
121 \\
32 \\
111 \\
43\end{array}$ & $\begin{array}{r}156 \\
153 \\
78 \\
159 \\
94\end{array}$ & $\begin{array}{l}182 \\
178 \\
108 \\
182 \\
127\end{array}$ \\
\hline $\begin{array}{l}1927-\ldots \\
1928 \\
1929 \\
1930 \\
1931\end{array}$ & 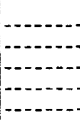 & $-\cdots$ & 19 & 75 & \begin{tabular}{r}
5 \\
\hdashline 141 \\
33
\end{tabular} & \begin{tabular}{r}
15 \\
\hdashline 16 \\
163 \\
65
\end{tabular} & $\begin{array}{r}32 \\
6 \\
40 \\
178 \\
88\end{array}$ & $\begin{array}{r}39 \\
25 \\
62 \\
198 \\
122\end{array}$ & $\begin{array}{r}48 \\
47 \\
77 \\
208 \\
149\end{array}$ & $\begin{array}{r}82 \\
64 \\
85 \\
225 \\
186\end{array}$ & $\begin{array}{r}107 \\
93 \\
102 \\
236 \\
218\end{array}$ \\
\hline
\end{tabular}

A typical illustration of the persistence in trend of deficient stream flow after a trend of excess precipitation has begun is presented in figure 12, which gives for the period 1922 to 1931 the accumulated departures from the average (1897-1932) of the monthly discharge of the Potomac River at Point of Rocks, Md., and the precipitation recorded at two representative stations, Westernport and Frederick, Md., within this drainage basin. The deficiency of precipitation during 1922 and 1923 was followed by 6 months of excessive precipita- 
tion. The discharge graph shows a corresponding general trend, but the stream flow did not increase materially until nearly 4 months after the precipitation had begun to exceed the normal. An example

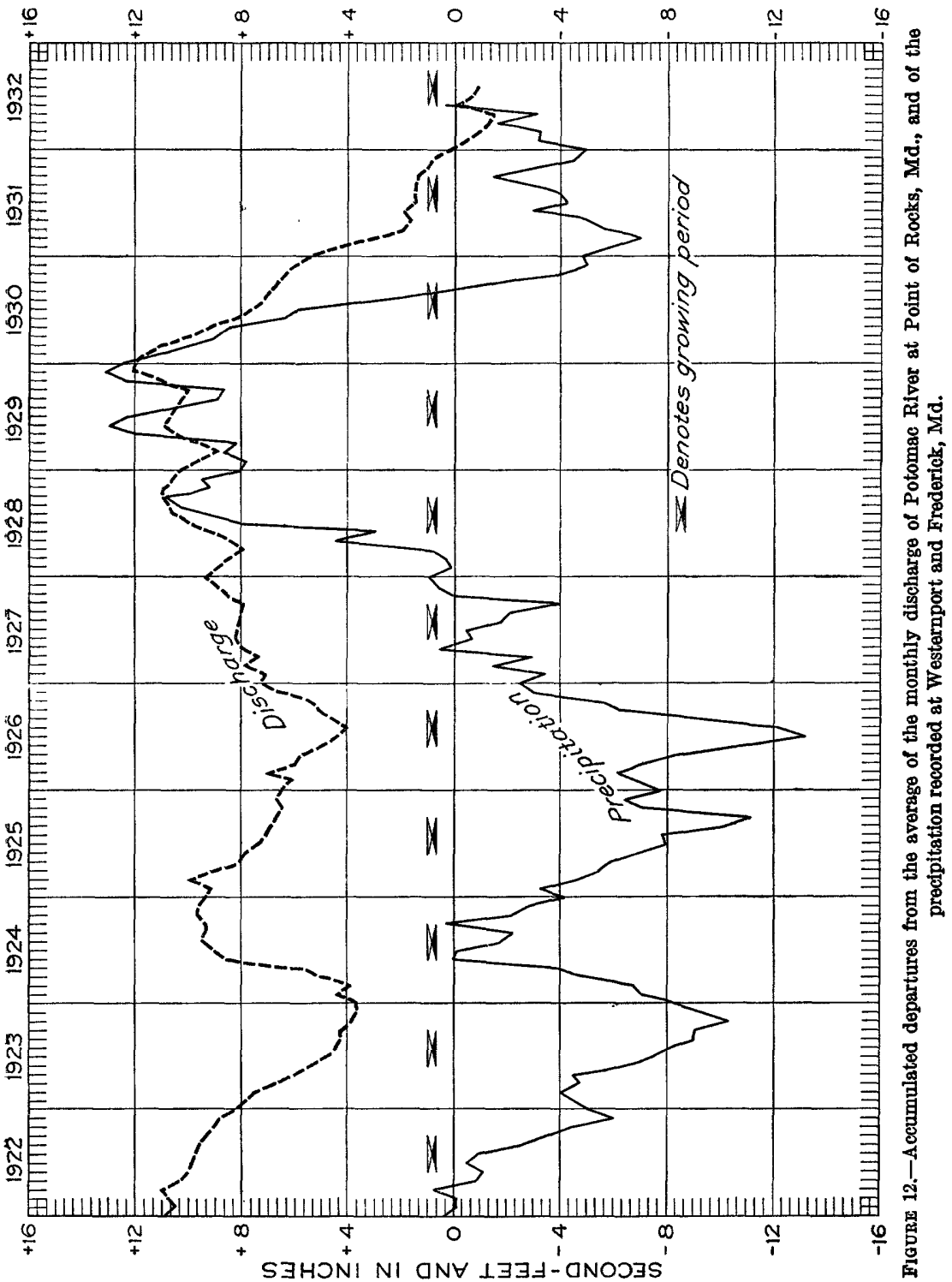

to SaN

of this lag or carry-over is shown by the downward trend of the discharge graph that persisted 17 months after general excesses of precipitation began, in March 1931. The recovery of the stream flow 
undoubtedly depends to a considerable degree on the way in which the precipitation occurs - that is, if moderate and well-distributed excesses in precipitation occur during the growing season, vegetation utilizes so much of the supply that there is little left to feed the streams. On the other hand, streams usually respond promptly to deficiencies in precipitation, for the run-off is the residual of the available supply remaining after the deduction of that consumed by transpiration and evaporation. Figure 12 shows several periods that illustrate this condition.

\section{DAMAGE}

Drought damages may be considered as affecting vegetation, domestic and industrial water supplies, health, power, navigation, and recreation and wild life. The droughts of 1930 and 1931 greatly interfered with many activities under each head, and the resulting losses in 1930 were probably greater than those sustained during any previous drought, owing partly to the fact that the uses and demands for water have vastly increased, even in the past few years.

\section{VEGETATION}

A general discussion of the relation of water supplies to vegetation is given on pages 14-21. The crop reports of the United States Bureau of Agricultural Economics afford a means for studying and comparing the effects of droughts on vegetation as related to agriculture. No systematic statistical information, however, is available in regard to the effects of droughts on natural vegetation, and the only bases for a statement relative to such effects are miscellaneous reports based upon personal observation.

During 1930 the detrimental effect of the drought on vegetation, both natural and cultivated, was marked. In 1931, however, the precipitation was adequate and sufficiently well distributed to supply the needs of vegetation in most parts of the country, and no detrimental effects of the drought appeared, except in a few localities, principally in North Dakota, South Dakota, Montana, and adjacent areas in Minnesota, Nebraska, and Wyoming. In fact, it was observed that in most parts of the country vegetation was especially vigorous in 1931. This may have been due to the lessened demands on the fertility of the soil that had been made by the stunted vegetation in 1930.

Although in 1930 the drought undoubtedly caused much damage to natural growth, no definite data are available to show its extent. Its effect on agriculture is indicated in table 2 and figures 13 and 14, which give for each State the composite yields of crops and the total precipitation during the principal growing months. The reports concerning the effect of the drought on crops indicate that as the yields 
for the country as a whole do not indicate conditions in individual States, neither do the yields for individual States indicate the extreme conditions that prevailed in certain localities.

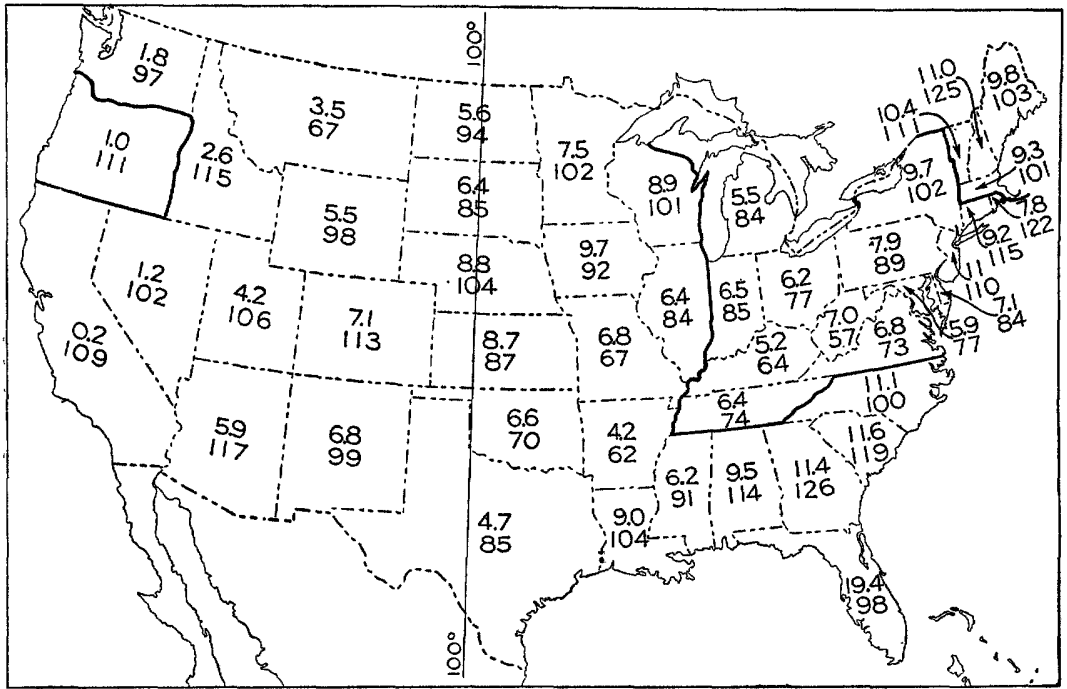

FigURE 13.-Total precipitation for June, July, and August, in inches (upper figure), and composite yields of crops per acre, expressed as percentage of average yields (lower figure), 1980. In areas indicated by heavy outline the precipitation in $\mathbf{1 9 3 0}$ was the lowest of record.

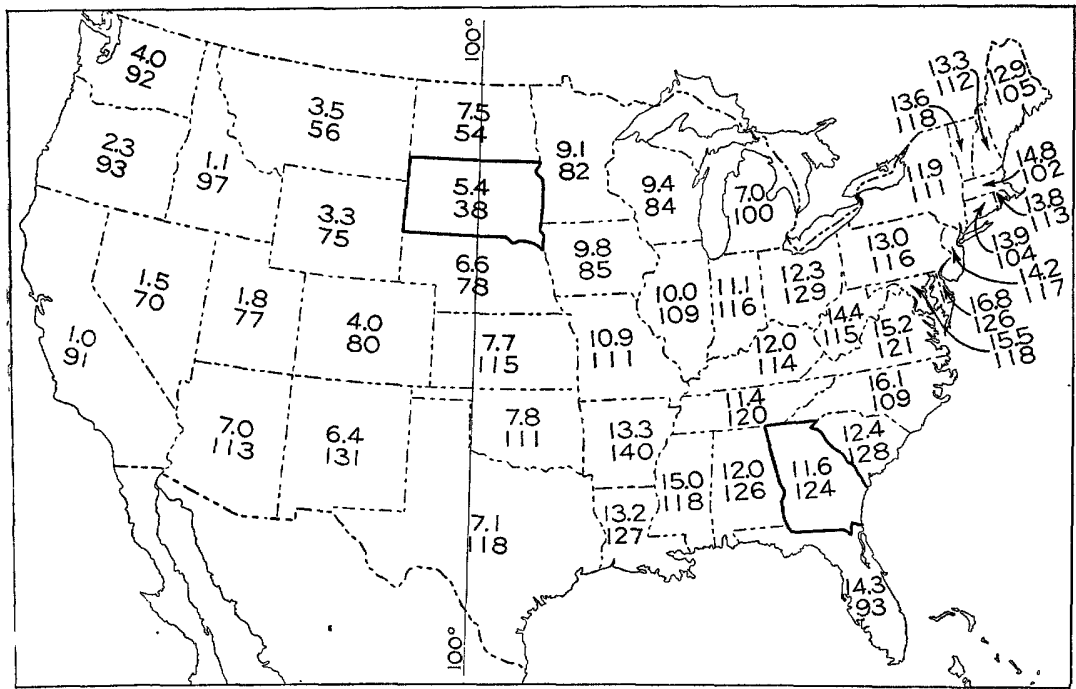

FIGURe 14.-Total precipitation for June, July, and August, in inches (upper figure), and composite yields of crops per acre, expressed as percentage of average yields (lower figure), 1931. In areas indicated by heavy outline the precipitation in 1931 was the lowest of record.

In humid sections of the country the growth of crops depends primarily on the quantity and distribution of rainfall during the grow- 
ing period. Temperature, humidity, and wind also have a marked effect. During the growing months of 1930 not only was the precipitation low but temperatures were unusually high, as indicated in figure 3, and hot winds prevailed. The humidity was low, the evaporation was high, and the usual dews were lacking. Plant growth was unable to withstand this combination of unfavorable climatic conditions.

Comparison of the precipitation for June, July, and August with the composite yields of crops in the humid and semiarid States for 1930 and 1931 as given in table 2 and shown in figure 15 indicates: that in States where the rainfall during the three growing months was $7 \frac{1}{2}$ inches or more the yields were nearly average or above and

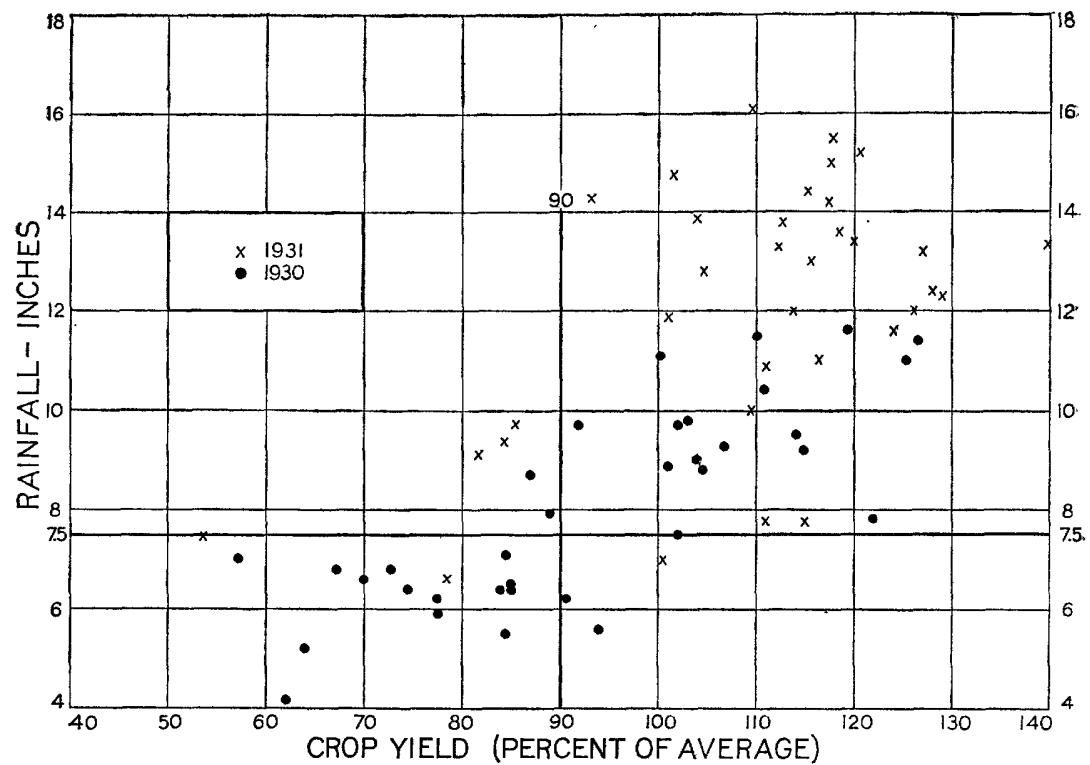

Frgure 15.-Relation of composite yields of crops per acre in 1930 and 1931 to total precipitation in June, July, and August for the 36 humid and semiarid States.

that in States where the rainfall during those months was less than $7 \frac{1}{2}$ inches the yields were below average. Most of the exceptions to. this general rule can be explained by the character of the vegetal growth, the distribution of precipitation, abnormally low or high temperature, or excessively hot winds.

The data on composite yields of crops and precipitation for 1930 show that the annual rainfall may not always be an indication of yields. The precipitation in Arkansas in 1930 was 95 percent of the mean, but the crop yields per acre were only 62 percent of the 10-year average, owing to the fact that conditions were not favorable for germination and that there was only 4.2 inches of rain during the 3 growing months. On the other hand, in New York the precipitation 
was only 82 percent of the normal, but the crop yield was 102 percent, as conditions were favorable for germination and there was adequate precipitation during the growing season. In Rhode Island, Connecticut, and New Jersey the precipitation in 1930 was also lower than in any other year of record, yet yields of crops for all these States were above normal.

Care must be taken in using precipitation records expressed as percentage of the mean to show the effect of droughts on agriculture or other activities, as a certain percentage of deficiency may not have the same effect in an area of high precipitation as it will in an area of low precipitation. This is illustrated by the data given in table 7 .

TABLE 7.-Composite yields of crops per acre and precipitation in North Carolina, Missouri, and Illinois, 1930

\begin{tabular}{|c|c|c|c|}
\hline & $\begin{array}{c}\text { North } \\
\text { Carolina }\end{array}$ & Missouri & Illinois \\
\hline $\begin{array}{l}\text { Yields } \\
\text { Precipitation: } \\
\text { Annual: }\end{array}$ & 100 & 67 & 84 \\
\hline Mean & $\begin{array}{l}50.44 \\
38.04 \\
75\end{array}$ & $\begin{array}{l}40.17 \\
31.27\end{array}$ & $\begin{array}{l}37.26 \\
27.89 \\
75\end{array}$ \\
\hline $\begin{array}{l}\text { June, July, and August: } \\
\text { Mean } \\
\text { 1930 }\end{array}$ & $\begin{array}{l}16.2 \\
11.1 \\
69\end{array}$ & $\begin{array}{r}12.7 \\
6.8 \\
54\end{array}$ & $\begin{array}{l}10.6 \\
6.4 \\
60\end{array}$ \\
\hline
\end{tabular}

In North Carolina a deficiency of 50 percent in the growing months would still leave over 8 inches of rainfall, which is adequate for the needs of vegetation, but in Missouri or Illinois a similar percentage of deficiency would reduce the precipitation to less than 7 inches, which is insufficient for the normal needs of vegetation.

The effect of the drought in the irrigated sections of the country was reduced to a minimum in both 1930 and 1931, because stored water was available to make up for deficiencies in the current supply, and also because it was possible to limit crop acreage to conform to the probable available water supply, as indicated by water in storage, snow surveys, and other information. The importance of adequate storage systems in connection with all irrigation projects as insurance against loss during years of low water was fully emphasized during 1930 and 1931. As indicated in table 13, in 24 reservoirs of the United States Bureau of Reclamation having a total capacity of $12,000,000$ acre-feet there was a net reduction in storage of 710,000 acre-feet in 1930 and of 1,500,000 acre-feet in 1931 . 


\section{DOMESTTC AND INDUSTRIAL WATER GUPPLIES}

In most States in 1930 there were marked and long-continued deficiencies in the flow of streams and the yields from ground water. These deficiencies persisted in many areas through 1931 and in some areas into 1932, resulting in a shortage of water for both domestic and industrial uses. The localities supplied by the natural flow of medium and small streams or by shallow wells were most seriously affected. In localities where facilities were available for storage, the total stream flow for the year was in general ample for usual activities. Communities that obtained their supplies from deeper wells that tapped productive water-bearing formations were also not much affected by the drought.

Indications of scarcity of water appeared early in the summer of 1930. In many localities usual supplies failed, so that for several months, especially in the larger towns and cities where municipal supplies were not provided with adequate reserves, it was necessary to curtail use and to provide additional supplies by drilling wells, Laying temporary pipe lines, or hauling water in tank cars.

The effect of the drought on domestic water supplies, both rural and urban, in New York, Ohio, and Kentucky is indicative of conditions that prevailed in other major drought areas.

In New York the State department of health reported that 65 municipalities were seriously affected in 1930 . Of these, 29 derived their supplies from surface-water sources and 36 from ground-water sources. In 1931 the effect of the drought continued in 32 of these municipalities, and in addition 3 others were affected. In 13 others that had been affected in 1930 shortage was averted in 1931 by the development of additional supplies. Hundreds of private wells and springs failed, and it became common practice for farmers to haul water several miles for stock and domestic purposes.

In Ohio the State department of health made surveys of 115 public water supplies, of which 94 depended on wells and 21 on surface sources. Considerable difficulty in respect to both quantity and quality was experienced in cities supplied from surface water, but little in cities served by wells, as their supplies had been adequately developed to provide for the contingency. In a few cities it was necessary to drill to deeper levels. Private wells in the southern part of the State failed almost entirely, and hauling water for many miles was necessary. In April 1931 the State legislature appropriated funds for use by the department of health to drill and install pumps in so-called "seal of safety" wells in southern and southeastern Ohio. The result was 48 successful wells out of 69 that were attempted.

In Kentucky the State board of health investigated 110 public water supplies and found that 33 cities had been on water rations. Conditions in Lexington, with a water-consuming population of about 
60,000 , supplied from four reservoirs with a small tributary drainage area, illustrate the seriousness of the situation. Restriction in the use of water became necessary in September 1930, and in October the city began the construction of a pumping plant with a 20 -inch pipe line to a point 8 miles away on the Kentucky River. This supplementary supply was made available in December and relieved the shortage. There were noticeable shortages in most rural sections.

Many industries were handicapped by an inadequate supply of water for process use and for the disposal of wastes. In numerous localities the provision of enough water for cooling and condensing in steam-power plants was a serious problem.

The rainfall during 1931 was greater and better distributed than that. of 1930, and many localities that had suffered from shortage of water during 1930 had enlarged their systems of supply. As a result comparatively few localities experienced any serious difficulty in 1931 from shortage of water for either domestic or industrial use.

\section{HEAITH}

In addition to shortage of water for municipal and industrial uses, considerable difficulty was encountered in many localities owing to the effect of the drought on the quality of the water, in regard to both mineral content and pollution. During the drought period the streams were almost wholly supplied from ground water, which normally has a higher mineral content than surface run-off. The lack of diluting run-off caused considerable difficulty and necessitated modifications in treatment at many filter plants. The serving of water of excessive hardness led to many complaints, both on account. of trouble in the use of the water and on account of deposits in heaters and in pipe lines, where no difficulty had been experienced with the water normally supplied. A menace to health was created in many localities because the streams fell so low that they were unable to carry sewage and other wastes.

Owing to the efforts and watchfulness of the health, water, and sanitation authorities, no widespread epidemic of communicable diseases occurred during the drought and there was comparatively little illness. Although a few cases of diphtheria, smallpox, scarlet fever, measles, and typhoid were reported by health officers in different sections, they were limited to small areas and were not a serious. menace.

Pellagra, a disease due to certain deficiencies in diet and usually present in many Southern sections, caused the most concern. Its: remedy lies in foods that supply these deficiencies, and such foods were issued to pellagra sufferers in addition to the staple rations. These foods consisted of milk, canned salmon, canned tomatoes, fresh fruit and vegetables, and powdered yeast. In the drought 
period prior to June 30,1931 , more than 30 tons of powdered yeast had been distributed to 18,302 persons in the drought area. The generous donations of hundreds of carloads of citrus fruits and fresh vegetables, especially from Florida and California, and of potatoes, cabbage, and other vegetables and foodstuffs from northern, central, western, and other States aided materially in maintaining standards of health.

School lunches were served for a period to more than 3,500 schools, attended by over 184,000 children. These no doubt aided considerably in maintaining satisfactory health conditions.

As an aid to the situation Congress provided, by an act approved February $6,1931, \$ 2,000,000$, to be administered through the United States Bureau of Public Health Service, to aid local health departments in the drought-affected areas. The Public Health Service reports as follows ${ }^{8}$ relative to the effect of drought on health conditions:

The years 1930 and 1931 were among the best years of which records have been kept, so far as the general health of the people is shown by mortality statistics and by reports of the prevalence of notifiable diseases.

The effect of the drought on the health of the people of the United States cannot at this time be measured with any degree of acccuracy. This does not mean that it has not had an effect, but merely that, whatever the effects may have been, they cannot be segregated from the many other factors which, taken together, cause high or low sickness and death rates in the population as a whole.

Serious outbreaks of such diseases as dysentery and typhoid fever, which might have resulted from interference with the usual water supplies in many places, have been avoided by scientific examination and treatment of the supplies. Epidemics of some other diseases have been prevented by immunization campaigns and other means. It may be, if food supplies have been deficient, that the consequent weakening effects will result in increases in the causes of illness and in the death rates in subsequent years. This cannot be definitely predicted, however.

\section{POWER 9}

Practically all important hydroelectric power plants generating electricity for public use are interconnected with steam plants in large systems. Water power and steam power are thus no longer competitors but have become partners, united to produce electric power as economically as possible. As the cost of operating a waterpower plant is considerably less than that of operating a steam plant, water-power plants are kept in operation as long as water is availablethat is, the supply of water instead of the demand for power is in general the controlling factor in the utilization of water-power plants.

The effect of the drought on hydroelectric power plants in the humid and semiarid States during 1930 and 1931 is probably best indicated by a comparison of the changes in the production of elec-

8 Personal communication.

- Statement by A. H. Horton, chief, division of power resources, U. S. Geological Survey. 
tricity by the use of water power from 1929 to 1930 and from 1930 to 1931 with the corresponding changes in the total production of electricity. The business depression lessened the demand for electricity during these periods, and this factor tends to disguise the effect of the drought on the production of electricity at hydroelectric plants. However, a comparison of the change in total production of electricity in the humid and semiarid States with the change in output by water power will indicate in a general way the effect of the drought on water-power plants, because a decrease in the production of electricity by the use of water power, especially if the change is relatively greater than that in the total production of electricity, will indicate a lack of water for the generation of power.

Table 8 shows that in 1930 the production of electricity by waterpower plants in all sections of the humid and semiarid portions of the United States was reduced as a result of the drought, and also that in 1931 the output by water power was reduced by the same cause in all sections except New England. There was no extended drought in New England in 1931.

TABLE 8.-Percentage change in production of electricity for public use in the humid and semiarid sections of the United States, 1929-31

\begin{tabular}{|c|c|c|c|c|}
\hline \multirow[b]{2}{*}{ Division } & \multicolumn{2}{|c|}{1929 to 1930} & \multicolumn{2}{|c|}{1930 to 1931} \\
\hline & $\begin{array}{c}\text { Total } \\
\text { output }\end{array}$ & $\begin{array}{c}\text { Output } \\
\text { by water } \\
\text { power a }\end{array}$ & $\begin{array}{l}\text { Total } \\
\text { output }\end{array}$ & $\begin{array}{l}\text { Output, } \\
\text { by water } \\
\text { power * }\end{array}$ \\
\hline $\begin{array}{l}\text { New England } \\
\text { Middle Atlanticactral } \\
\text { East North Central } \\
\text { West North Central } \\
\text { South Atlantic } \\
\text { East South Central }\end{array}$ & $\begin{array}{l}-3 \\
\pm 1 \\
-5 \\
+6 \\
+8 \\
+6\end{array}$ & $\begin{array}{l}-20 \\
-10 \\
=15 \\
-10 \\
-29 \\
-3\end{array}$ & $\begin{array}{l}0 \\
-3 \\
-7 \\
-2 \\
-6 \\
+1\end{array}$ & $\begin{array}{l}+16 \\
-9 \\
-19 \\
-33 \\
-13 \\
-1\end{array}$ \\
\hline
\end{tabular}

a Figures for output by water power are adjusted for increase in capacity of water-power plants.

\section{NAVIGATION}

The Chief of Engineers, United States Army, ${ }^{10}$ reports on the effect of the drought on navigation on the inland-waterway system of the Mississippi Valley as follows:

The more important components of the inland-waterway system of the Mississippi Valley are the lower Mississippi, below the mouth of the Ohio, where a depth of 9 feet is maintained by dredging through the river bars; the Ohio River, where a depth of 9 feet is secured by locks and dams; feeder tributaries of the Ohio, including the Monongahela, the Allegheny, the Kanawha, the Cumberland, the Tennessee, and others, the most used of which are also improved by locks and dams; the middle Mississippi to above St. Louis, where a depth of 9 feet is to be provided by contraction works and dredging; the upper Mississippi from St. Louis to St. Paul and Minneapolis, the immediate status of which is a project for a 6-foot channel obtained principally by contraction works and by dredging

10 Personal communication. 
but where a 9-foot channel is to be provided by locks and dams; the Missouri, in process of improvement by contraction works to afford a depth of 6 feet; and the Illinois, in course of improvement to afford a 9-foot connection with the Great Lakes.

The 1930 drought brought about a prolonged low-water season on these rivers, the effect of which was mitigated to some extent by the stabilized condition of low water. On the more important parts of the system navigation was kept in motion without serious interruption. Channel dredges had to be kept in operation for a much longer period than normal. On the upper reaches of some of the tributaries of the Ohio, with limited drainage areas, the evaporation, leakage, and lockage losses at the navigation dams exceeded the inflow, and the pool depths could not be maintained; but by using special effort in preventing leakage at the dams throughout the system, supplemented by channel dredging, the navigable capacity of the Ohio and its most important feeders was well maintained. Despite heavy drafts on the reservoirs at the headwaters of the Mississippi, the deficient flow in the upper Mississippi reduced the limiting channel depth to about $4 \frac{1}{2}$ feet.

In summary, the effect of the 1930 drought was felt by navigation, but the consequences were not highly serious as far as navigation was concerned.

In the lower Mississippi River the maintenance of the 9-foot channel was rather less difficult in 1931 than in 1930, even though lower river stages were reached. On this river bars occasionally form which delay navigation until they can be reached by the dredges and a channel provided. The time lost from this cause during 1931 did not exceed that occurring during an average year, and the amount of material dredged in channel maintenance during 1931 was 12 percent less than in 1930. The prolonged and continuous low stages resulted in a condition of stability favorable to channel maintenance.

On the Ohio River the project depth of 9 feet was maintained throughout the year. The shortage of water to fill the pools on the Monongahela River, which had been experienced in 1930, was relieved by rainfall in December 1930, and navigation on that stream experienced no difficulties from water shortage in 1931 . The water supply on the other tributaries of the Ohio was also adequate for navigation purposes.

On the middle Mississippi, from the mouth of the Ohio to the mouth of the Illinois, above St. Louis, the extremely low stages reached in 1931 required the execution of intensive maintenance dredging, but satisfactory navigation conditions were maintained on this reach, as well as up the completed portion of the Illinois.

Serious effects of the drought were experienced in 1931 in the upper Mississippi between the mouth of the Illinois and St. Paul and Minneapolis. The storage reservoirs on the headwaters of this stream were depleted by the preceding deficient run-off, and their supply was completely exhausted at the end of 1930 . The storage recovered in the winter and spring of 1931 was too small to be utilized in increasing the low-water flow below St. Paul. New low-water stages were attained, and the navigation depth was reduced to as little as 4 feet. Navigation was seriously impaired. The construction of the locks and dams provided in the project now authorized for the improvement of this reach, when completed, will make this section of the river independent of drought conditions.

Since the Missouri River was not completed to an extent sufficient for commercial navigation, the low-water conditions had no serious effect. They produced a favorable situation for the prosecution of the regulating works. Since, however, these works become effective in correcting the channel through their influence on high flows, the lack of high water deferred the completion of the project. 
The drought in the South Atlantic States in 1931 had an injurious effect upon the navigation of some of the upper reaches of streams still used for that purpose. The packet-boat service on the Savannah River between Augusta and Savannah began carrying partial loads in the latter part of May 1931 and suspended operations from the latter part of August to the middle of December because of low stages resulting from the drought. Navigation was also suspended for a period of about 6 weeks on the Alabama River. In general, however, the lack of high flows during the year materially reduced the sediment deposits in the lower reaches of the stream, to the advantage of navigation conditions, and with a reduction in necessary maintenance dredging.

In general, while drought conditions in 1931, as in 1930, called for increased activities of the department in the maintenance of navigable channels on nontidal rivers, the consequences were not serious so far as navigation is concerned.

\section{RECREATTON AND WHD IJWE}

During the last few years the use of water for recreation has greatly increased, and this use is recognized as a factor in the consideration of questions relating to water supply. The low water during 1930-31 interfered with fishing, bathing, and boating, both on account of inadequate water supply and on account of increased pollution. Water supplies of many refuges and breeding grounds were so reduced that adequate feed was not available for migratory birds.

\section{RELIEF}

In many rural localities the droughts of 1930 and 1931 caused hardship through the failure of food, forage, and cash crops and through scarcity of water for both human beings and stock. The effect throughout the country, however, was not severe enough to prevent the building up of heavy surpluses of almost every agricultural product. The resultant low price levels, already beaten down by the economic depression, greatly reduced the ability of those in the drought areas to meet the situation adequately without outside relief. Such relief was provided by Federal appropriations and by gifts through the American Red Cross. Because the drought effects were spotty, varying widely even between adjacent counties, it is difficult to generalize. Without question, however, the drought caused much hardship, with corresponding needs for relief, especially among the "marginal" farmers, who are none too well off in the most prosperous times.

In its effect on water supplies the drought made haulage of water, sometimes in tank cars over long distances, necessary to keep stock alive. Transportation of fodder was also necessary, with the alternative of moving stock out of the area or else selling at a heavy loss.

Failure and low price of cash products, whether in cotton, cattle, wheat, or corn, was a principal cause for need of drought relief. Many families dependent on cash crops, with no vegetable gardens whereby they might live directly off the land, found that low prices 
and depleted yields left them without sufficient means to buy the bare necessities.

Enough relief needs were traceable to the drought to bring the American National Red Cross into action under its policy of functioning to prevent suffering due to an "act of God." Relief measures' were started in several States late in the summer of 1930 by local Red Cross chapters, and early in the fall it became evident that outside help would be needed. Accordingly, the Red Cross took up the work and appropriated $\$ 5,000,000$ from its reserve. In addition, $\$ 10,589,780.19$ was raised by a special campaign for the period ending June 30, 1931 . Notwithstanding this, many believed that the situation was so serious that it could be adequately handled only by aid from the Federal Government. As a result Congress passed four measures for drought relief.

Federal aid to drought sufferers was first made in the fall of 1930 from the balance in a loan fund which Congress had provided in the preceding March under the Department of Agriculture for aid in certain States that had suffered from storms and other causes. From this fund $\$ 230,350$ was distributed in small loans for sowing pasturage crops in Alabama, Missouri, Oklahoma, and Virginia. The terms under which this fund was made available prohibited its use in other States, and to meet the situation Congress made available $\$ 67,000,000$, to be administered by the Secretary of Agriculture, for loans and advances to drought sufferers, by the acts of December 20, $1930(\$ 45$,$000,000)$, February 14, $1931(\$ 20,000,000)$, and February 23, 1931 $(\$ 2,000,000)$. In addition $\$ 2,000,000$, to be administered by the United States Public Health Service, was made available by the act of February 6, 1931.

The areas that suffered the most are shown in figure 16 , which indicates where relief measures under the Red Cross were necessary.

From August 1930 through June 1931 direct expenditures for relief amounted to $\$ 10,894,835.62$, and aid was given to 614,504 .families, aggregating $2,765,000$ persons ${ }^{11}$ in 1,057 counties in 23 States. In addition to the direct expenditures, food, clothing, etc., having an estimated value of $\$ 990,000$ were distributed. The services of relief agents were in the main contributed. The peak of the relief was reached the last of February 1931, when assistance was being given to 460,240 families aggregating $2,081,000$ persons.

Conditions improved so greatly during the spring and early summer of 1931 that after June 30 the only States in which extensive drought relief was necessary were Iowa, North Dakota, South Dakota, Nebraska, Montana, and Washington. An additional expenditure of $\$ 2,266,860.73$ was required to cover the needs of these States after June 30,1931 , and aid was given to 243,368 persons. 
In all the counties where drought relief was given, the recipients of aid were strongly urged to plant the garden seeds being given to them, as a further safeguard to the health of their families. Reports during 1931 from various States indicate that the garden-planting plan was generally followed in the areas that had suffered during 1930. This was a large factor in eliminating food shortage in 1931. During 1931, 611,000 seed collections were distributed. The seeds in each of these collections were sufficient to plant about a one-fourth-acre garden plot and included from 13 to 18 varieties of vegetables selected by the United States Department of Agriculture with respect to their suitability to the areas in which they were to be used. An important

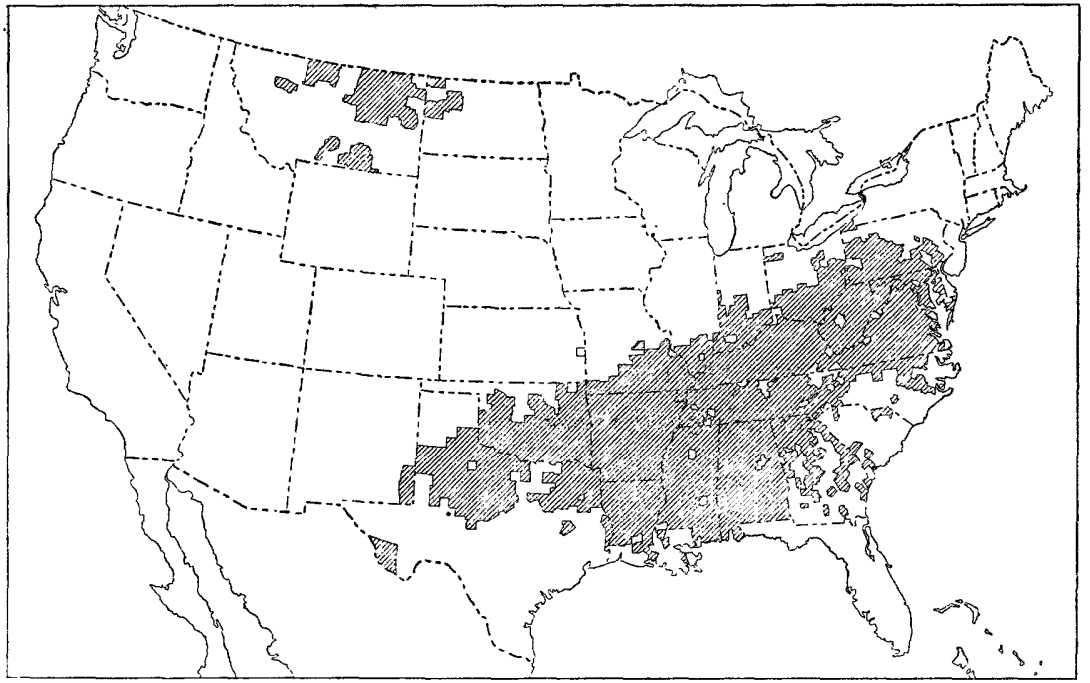

Figure 16.-Areas where Red Cross gave drought relief, August 1930 to June 1931.

indirect benefit from the drought has been that it has taught people in the areas affected to grow sufficient food crops for family needs. It is estimated that the retail money value of vegetables produced from Red Cross garden seeds in 1931 amounted to $\$ 20,000,000$.

More than 600 freight carloads of foodstuffs were donated to the Red Cross for the drought sufferers. These were distributed in the most severly affected regions. Quantities of clothing for children were made by Red Cross women volunteers, and used clothing was reconditioned for adults. School attendance everywhere in the drought sections was materially improved by the Red Cross school-lunch program and by the distribution of warm clothing to the children.

One type of relief given extensively by the Red Cross was stock feed. Feed was given to 61,841 families in all but 4 of the 23 affected States. Reports indicated that thousands of cattle, horses, mules, hogs, and 
chickens were saved through this feed. In Arkansas alone 34,018 families received free feed for livestock from the Red Cross.

This huge relief task was conducted by 1,225 chapter-paid and 517 nationally paid workers with the aid of 37,762 volunteers. The areas in which Red Cross relief was necessary were in general those of marginal production and lack of diversification, both in agriculture and in other activities. This largely accounted for the inability of the people to handle the situation locally. There were other areas where the drought was fully as severe in which outside relief was not necessary.

Tables 9 and 10, from a report entitled "Relief work in the drought of 1930-31", indicate the extent and type of the aid given by the Red Cross from August 1, 1930, to June 30, 1931.

TABLE 9.-American National Red Cross drought relief, financial statement June 30, 1991

Available funds:

American National Red Cross $\$ 5,000,000.00$

Contributions to drought relief fund $10,589,780.19$

Expenditures:

$15,589,780.19$

Food.

Clothing.

School lunches

Feed for livestock

1930 garden and pasturage seed.

1931 garden seed

Yeast for pellagra control

Other medical aid

Family service

Field supervision, accounting, and other field expenses.

Cash grants to chapters, final distribution of which was not reported by June 30,1931 .

Provision for chapter continuation of service

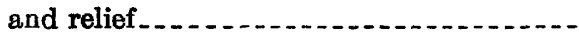

Other relief expenditures including fuel, bedding, miscellaneous supplies, etc.....
$\$ 7,229,104.79$

$488,668.85$

$165,599.52$

$346,415.60$

$276,122.51$

$492,119.52$

$15,903.06$

91, 906. 95

109, 052. 30

$835,095.72$

$582,130.96$

146, 979. 04

$115,736.80$

$10,894,835.62$

$4,694,944.57$

Balance available for completion of drought relief program..... 


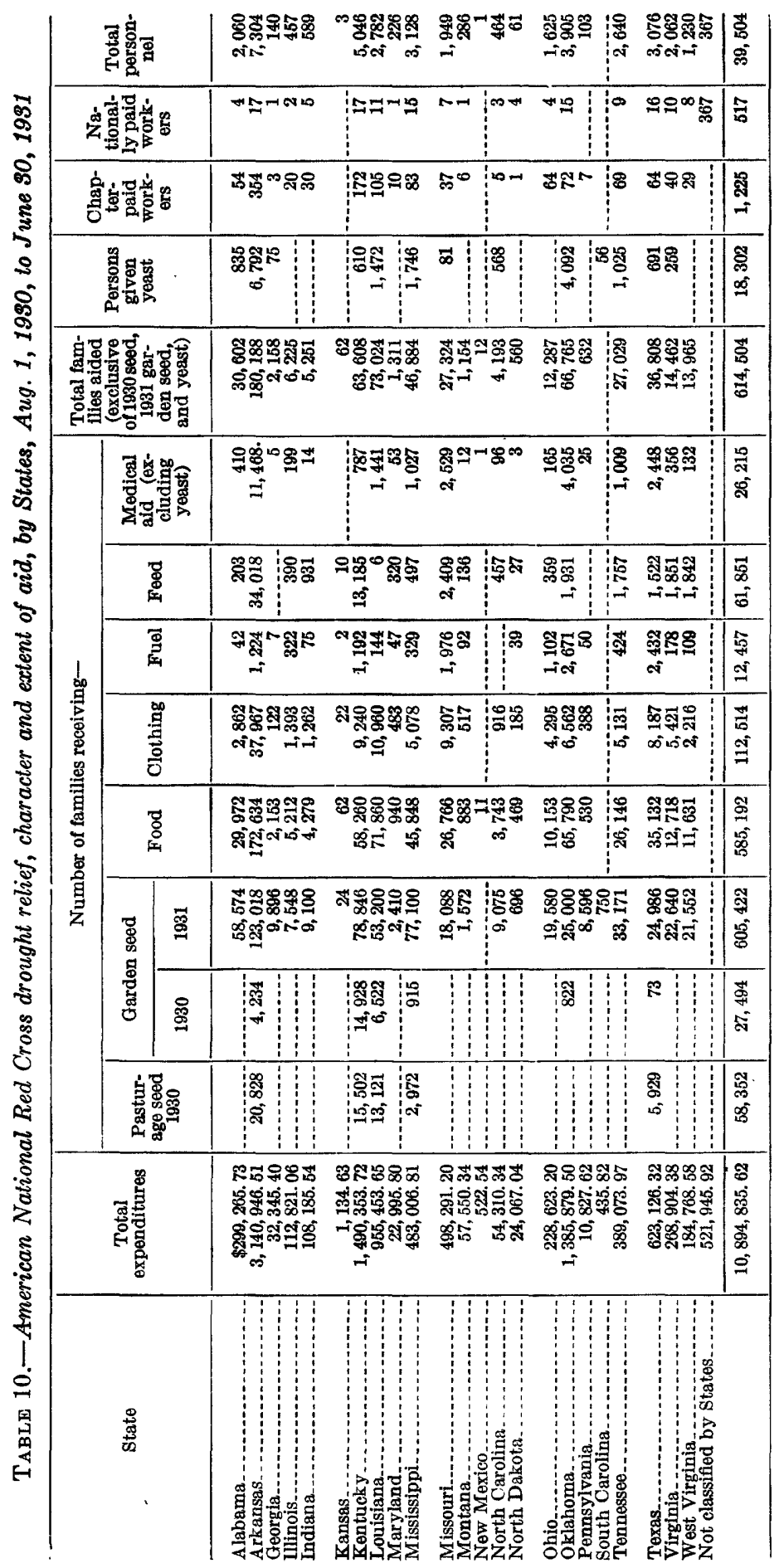




\section{DROUGHT OF 1934}

During much of 1934 for most sections of the country the major weather phenomena-precipitation, temperature, and wind movements-were in some respects abnormal. As a result, noticeable drought conditions in varying degrees of severity prevailed, as indicated on plate 1, in all the arid States except Washington, Oregon, California, Nevada, northern Idaho, and western Montana; in all the semiarid States except most of Texas; and in portions of the hamid States in the upper Mississippi, Ohio River, and Great Lakes drainage basins. Drought conditions were most severe in the semiarid States, especially in the Dakotas, Nebraska, and Kansas, and in the adjoining States on both the east and the west, and it was in this area that the damage effect of the drought was the greatest. In California, although the annual precipitation was only 76 percent of the mean, it was so well distributed during the rainy season that with the available storage agriculture did not suffer seriously except in Imperial Valley, which obtains its water supply from the Colorado River. The extremely low run-off of the Colorado River was due to drought conditions in the upper basin States.

In 1931 the annual precipitation in California was 104 percent of the mean, but its distribution during the rainy season was so unfavorable that the irrigation supply, including storage, was insufficient to meet the needs of agriculture. As a result there were severe economic effects due to deficient water supply. Conditions in California during 1931 and 1934 illustrate the errors that are liable to enter into any conclusions as to droughts in the arid and semiarid States based upon annual records of precipitation.

\section{CAUSES}

Although in certain areas climatic conditions in previous years contributed in some degree, the drought of 1934 resulted primarily from deficient and unfarorably distributed precipitation, excessive heat, and warm winds, which in general prevailed in that year in all States except those bordering on the Atlantic seaboard, eastern Gulf of Mexico, and northern Pacific coast. These climatic conditions are indicated in table 11, plate 1 , and figures 17 and 18, and are summarized in general on pages 47-52. 


\section{PRECIPITATION}

In 7 of the 31 humid States the precipitation for 1934 was 85 percent of the mean or less. These 7 States were in the Ohio River, Great Lakes, and upper Mississippi River drainage basins. In Ohio precipitation was 69 percent of the mean, breaking the previous record. In Indiana it was 74 percent of the mean, which equaled the low point of 1930. Precipitation in all the semiarid States except Texas was below 85 percent of the mean. Previous minima were broken in North Dakota, with 54 percent, and South Dakota, with 63 percent. In all the arid States it was below 85 percent of the mean, except in Washington and Oregon, where it was above the mean, and in Idaho and Nevada, where it was 89 percent of the mean. In the remaining arid States Wyoming had the least deficiency, with the precipitation 78 percent of the mean. Colorado broke previous records with 65 percent.

The serious effects of the drought resulted as much from unfavorable distribution of precipitation as from the deficiency for the year. During the 3 winter months, starting with December 1933, 25 States had noticeable deficiencies in precipitation, receiving less than 85 percent of the normal. These included all the humid States except Louisiana, Arkansas, West Virginia, Maryland and Delaware, New York, and the New England States. In the semiarid region the shortage was limited to the Dakotas; in the arid region, to Wyoming, Nevada, Arizona, and New Mexico. The States where major shortages occurred were in the Missouri, upper Mississippi, Ohio, and Great Lakes drainage basins.

During the spring (March through May) shortages in precipitation were greater and more widespread than during the winter, 27 States having noticeable deficiencies. These included the humid States in the upper Mississippi, Ohio, and Great Lakes drainage basins, all the arid States except Washington, and all the semiarid States except Texas. In these areas there were only 5 States in which the precipitation was as great as 70 percent of the normal, and in 9 States it was less than 50 percent. In the critical areas, especially in the Dakotas, Nebraska, Minnesota, and Iowa, the total precipitation ranged from only 29 to 44 percent of normal. Conditions were better in the southern and eastern humid regions, where precipitation was almost normal or above in all the Atlantic coast and Gulf States and in Arkansas and Tennessee.

During the summer (June through August) major shortages in precipitation disappeared in all but 17 States-those in the semiarid region and the States bordering it on the east and west except Louisiana, also New York, Washington, Idaho, and Utah. In no State, however, was the deficiency as great as during the two preceding quarters, and the effects would probably not have been especially seriqus if it had not been for the shortage in the winter and spring. 


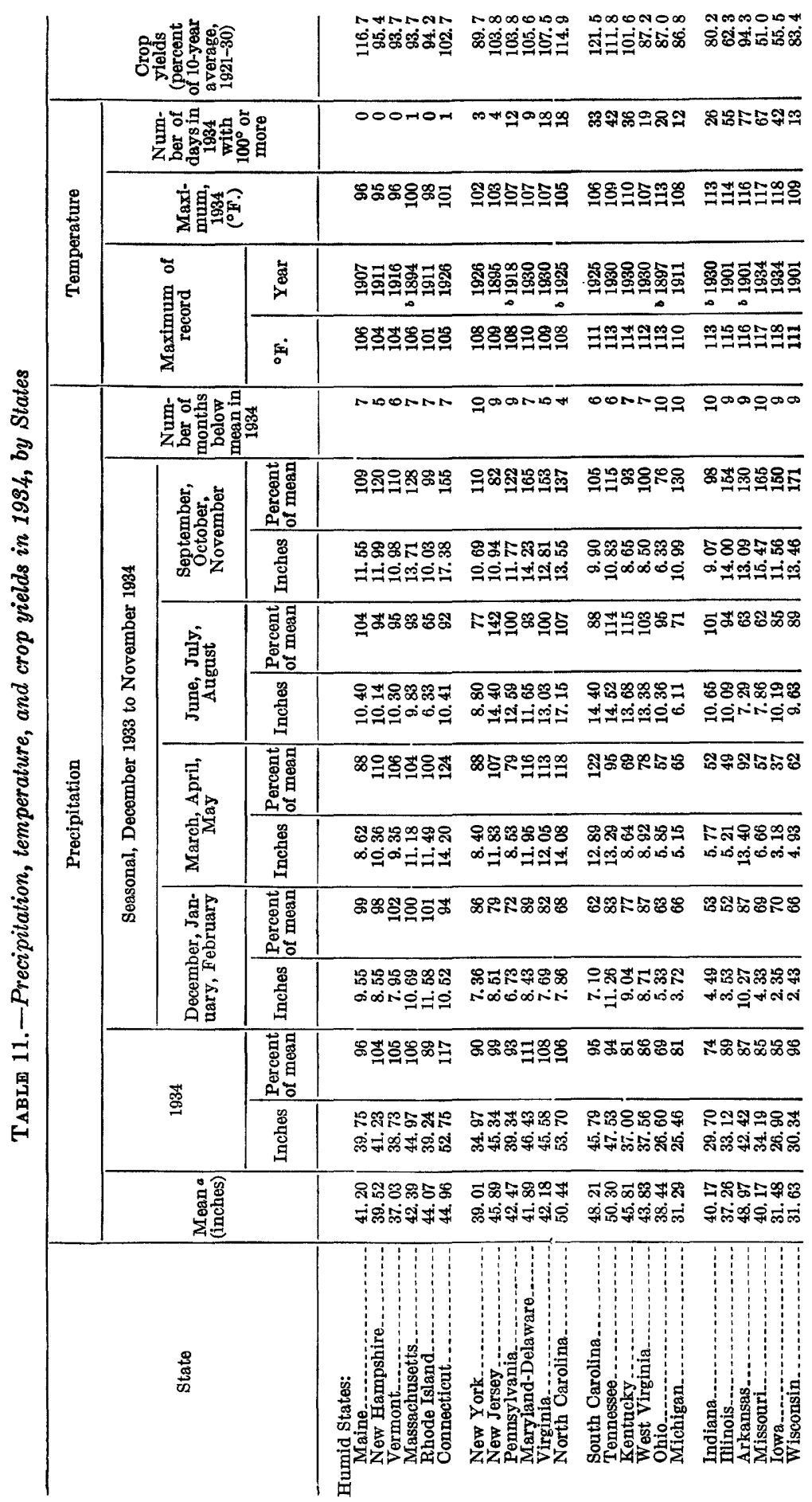




\begin{tabular}{|c|c|c|}
\hline 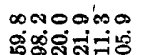 & 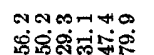 & 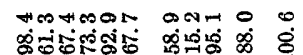 \\
\hline
\end{tabular}

\begin{tabular}{|c|c|}
\hline 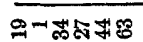 & ஜКธธిสడ \\
\hline
\end{tabular}

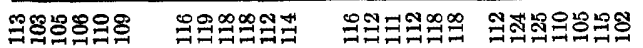

$\underbrace{2}$

\begin{tabular}{|c|c|c|}
\hline & & 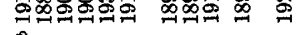 \\
\hline
\end{tabular}

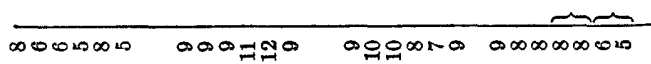

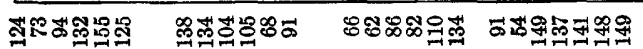

\begin{tabular}{|c|c|c|c|}
\hline 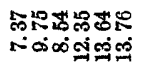 & 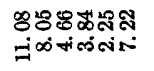 & 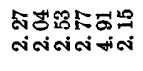 & 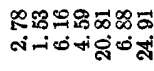 \\
\hline 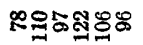 & 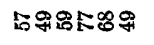 & 유: & வ \\
\hline
\end{tabular}

\begin{tabular}{|c|c|c|c|}
\hline 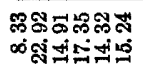 & 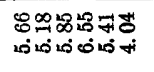 & 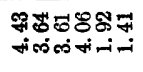 & 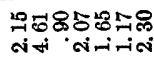 \\
\hline 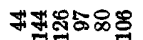 & 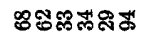 & 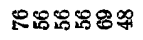 & 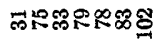 \\
\hline
\end{tabular}

\begin{tabular}{|c|c|c|c|}
\hline 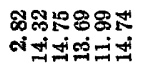 & 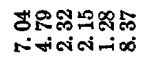 & 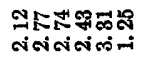 & 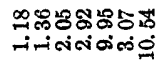 \\
\hline 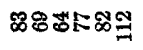 & 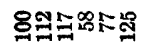 & 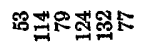 & 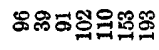 \\
\hline
\end{tabular}

\begin{tabular}{|c|c|c|c|}
\hline 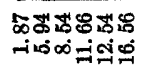 & 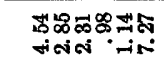 & 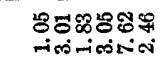 & 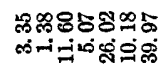 \\
\hline 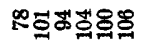 & 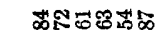 & 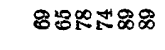 & 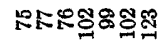 \\
\hline 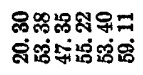 & 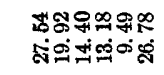 & 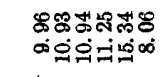 & 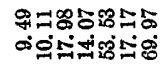 \\
\hline 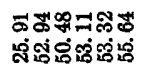 & 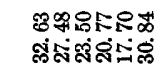 & 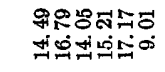 & 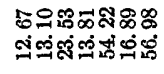 \\
\hline 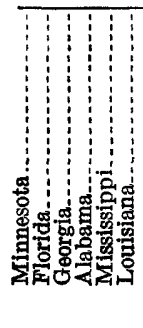 & 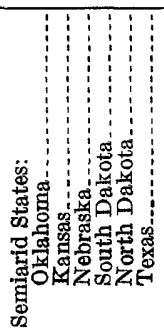 & 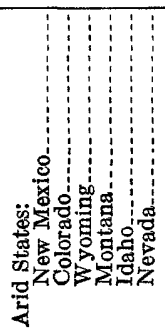 & 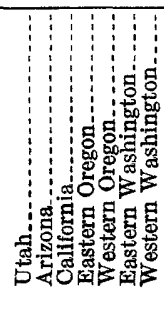 \\
\hline
\end{tabular}


During the fall (September through November) precipitation was normal or above in 34 States. It was less than 85 percent of normal in only 8 States-New Jersey 82 percent, Ohio 76, Florida 73, North Dakota 68, Colorado 62, Arizona 54, New Mexico 66, Montana 82.

\section{THMPERATURE}

During 1934, especially in the first 8 months, unusual temperatures were noticeable in most sections of the country. The winter in the Northeastern States was much colder than usual, and in February most previous records as to both severity and duration were broken in this area as far south as Virginia. On the other hand, States west of the Mississippi River had a mild winter. The spring, in general, was late in the Northeastern States and early in the Northwestern States.

The summer was unusually warm in all parts of the country, and the year's accumulated temperatures in practically all sections were above normal, as indicated in table 11 and by the lines on figure 17. The number of days during June, July, and August in each State on which temperatures of $100^{\circ}$ or more were recorded and the maximum temperature for the same months are also indicated in figure 17. Previously recorded maxima were equaled or exceeded in 10 States. Temperatures of $100^{\circ}$ or more occurred in 7 States on 75 days or more, and in 14 States on 50 days or more. Kansas City, Mo., had temperatures of over $100^{\circ}$ on 14 consecutive days. All States west of the Mississippi had maximum temperatures of $112^{\circ}$ or more except Louisiana, Oregon, and Wyoming, where the maxima were $109^{\circ}, 110^{\circ}$, and $111^{\circ}$, respectively. East of the Mississippi, and exclusive of New England, there were only 3 States in which maximum temperatures did not exceed $102^{\circ}$, and in 3 States $110^{\circ}$ was exceeded.

The fall and early winter temperatures were generally above normal except for a short cold spell in December in the Southeastern States.

\section{WIND}

Except for their warmth and accompanying dust, wind conditions were not unusual during 1934. Dust storms were so frequent during the period November 1933 to May 1934 that the Weather Bureau circularized its stations east of the Rocky Mountains for reports relative to their character. A summary of these reports ${ }^{12}$ indicates that there were five major storms, considering only those that overspread a considerable section of the country. In addition to these major storms, there were many others confined to portions of the Great Plains and adjacent sections.

12 Mattice, W. A., Dust storms, November 1933 to May 1934; Monthly Weather Rev., February 1935, pp. 53. 
The principal causes of the disastrous soil blowing in 1933 and 1934 were continuous high winds, intensive cultivation, the practices of burning stubble, low rainfall, and lack of organic matter and soil moisture to hold the soil in place. At the beginning of the plowing and planting season of 1934 there was a marked shortage of soil moisture. This, combined with deficient precipitation during the spring, resulted in the ground becoming too dry to withstand wind action.

The surface inaterial over large areas of the country, especially in the arid and semiarid regions, consists in part of loess-that is, wind-blown material that has been deposited throughout the ages and has always been more or less subject to movement by winds when it becomes dry. The close cropping of vegetation due to overgrazing, the unwise breaking up of lands that are valuable chiefly for

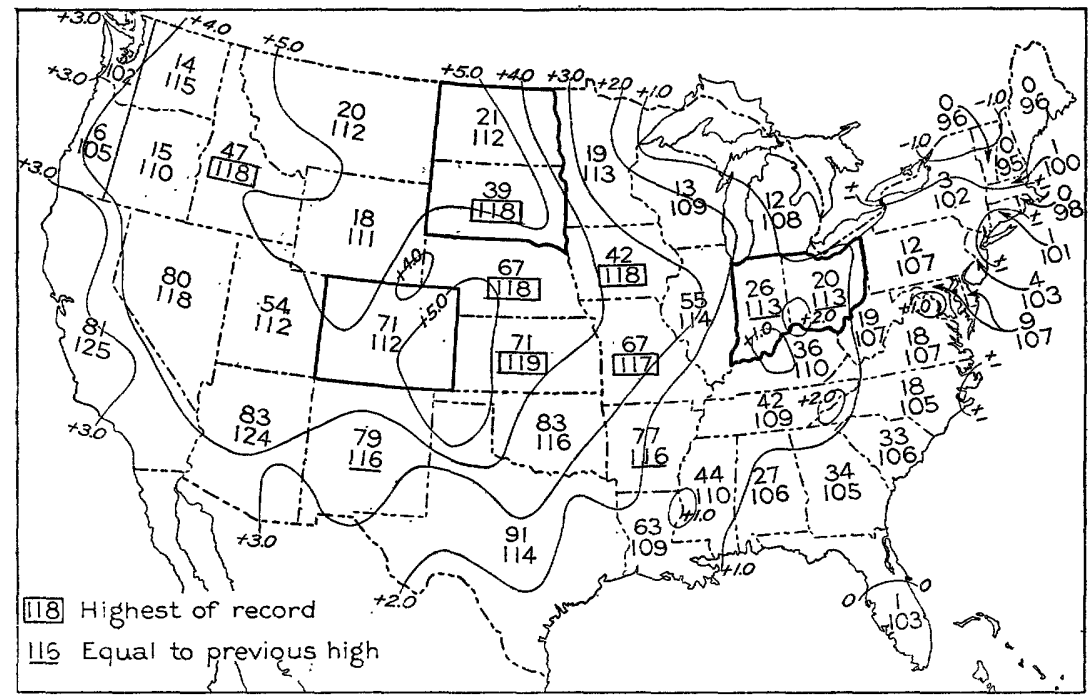

Figune 17.-Temperatures, 1934. Upper figure, number of days with maximum of $100^{\circ} \mathrm{F}$. or more. Lower figure, maximum temperature during June, July, and August. In areas indicated by heavy outline the precipitation in 1984 was lowest of record. Lines denote variation in average temperature from normal.

grazing, and the drying of the surface, especially in years of drought, have greatly reduced the ability of this material to resist movement by the winds. Although the effects have been serious in many localities, they were probably not as bad as would be indicated by the photographs and descriptions that appeared in press statements.

The great mantle of wind-blown silt that covers a large part of the interior of the country indicates that dust storms have been a common occurrence in the geologic past. Although we are now chiefly concerned with the damage done by wind erosion in the recent dust storms, it is interesting to note that to these ancient silt deposits, called loess, is largely due the productivity of the great farming regions 
included in the Mississippi Valley, and there are many who believe that though the effects in the areas in which the dust originates may be detrimental, there may be counterbalancing benefits in areas in which it is deposited.

Of the major dust storms that of May 9-12, 1934, created much widespread interest as to both its extent and its intensity. Following are reports from various weather bureau stations in regard to this and other storms:

Bismarck, N. Dak.: Although frequent dust storms have visited North Dakota this spring, those on 11 days warrant special mention. The most severe of these storms occurred on April 21 and 22. The velocity of the wind was greater on the 21 st, but the volume and density of the dust were greater on the $22 \mathrm{~d}$. The latter storm caused the most comment, because of the fact that the $22 \mathrm{~d}$ fell upon a Sunday, and travel by both automobile and by plane was hazardous and difficult. Several aviators have reported that dust was encountered at all levels up to 14,000 feet. A report on the storm of April 22 follows: A severe dust storm began $11 \mathrm{a} . \mathrm{m}$. and continued all day, ending the night following. Visibility at the station was as low as 200 yards at various times. *** This was the most severe dust storm experienced at the Bismarck station during the 28 years that I have been in charge.

Milwaukee, Wis.: Dust reported on about 19 dates previous to May. The storm on May 9-10, the worst dust storm of which there is any recollection in Wisconsin, covered the entire State. There were fresh to strong winds, which drifted the soil in the fields and in places uncovered newly sown grains. By the morning of the 10th dense dust clouds covered the sky, and this condition continued all day.

Cincinnati, Ohio: First evidence of the western dust storm reached Cincinnati shortly after noon on May 10. It was first observed on the hilltops at about 12:15 p. m. and at the Lunken Airport at 12:30 p. m. Visibility was greatly reduced, being only 3.4 miles from $2: 30 \mathrm{p} . \mathrm{m}$. to after $3 \mathrm{p} . \mathrm{m}$.

Pittsburgh, Pa.: The dust storm that was reported at several western stations on the morning of May 10, 1934, was first observed in the vicinity of Pittsburgh as a peculiar pale-yellow haze in the upper air about 6:15 p. m. of the $10 \mathrm{th}$. At the airport station the dust was most dense at the 6 and 7 a. $\mathrm{m}$. observations on the 11th, when the visibility was reduced to 1 mile.

Boston, Mass.: A veil of dust appeared in the air shortly after daybreak on May 11 in New England and undoubtedly moved eastward over the ocean during that day. The dust was so fine that it appeared much as a high haze and was at an altitude of some $\mathbf{5 0 0}$ feet or more, where visibility was reduced to a fraction of a mile, whereas visibility on the ground was up to 2 miles.

Baltimore, Md.: The dust was in the lower and upper atmosphere, within 2 to 3 miles of the earth's surface. In the lower atmosphere the density thickened after 8 a.m. May 11, at which time visibility was between 6 and 8 miles, decreasing to 1 and 2 miles between 10:30 a. m. and 2:30 p. m.

Charleston, S. C.: Southerly winds on May 10 and 11 prevented the dust in the air over the central sections of the country from reaching this station, but on the 12th there was a sudden shift to northerly at 4:20 a. m. By 5:45 a. m. our airport station was reporting dust, and dustiness increased until 7:40 a. m., when the visibility had decreased to 4 miles.

Vicksburg, Miss.: May 11, sunset yellow due to dust. Visibility 21/2 miles in the west. Continued until 9 a. m. of the 13 th. 


\section{EFFECT ON GROUND AND SURFACE WATER}

GENERAL EFEECT

A brief discussion of the general effect of droughts on ground and surface water is given on pages 11-22 and may be summarized as follows: That part of the precipitation which is not taken up directly by plant growth or by evaporation passes as surface flow into streams and lakes or goes to make up soil moisture and to replenish the ground water. In an ordinary year the ground-water table reaches its low point at the end of the growing season and is built up during the winter and early spring, following closely the precipitation. It recedes during the late spring, summer, and fall, unless there is excessive precipitation. Both medium and high stream flow result, in the main, from surface run-off following soon after precipitation. Low stream flow and also the flow in springs and wells largely result from seepage from ground water. Reductions in ground-water yield occur in the main when the ground-water table approaches closer and closer to the level at which the water from it enters a stream, spring, or well. In areas where the topography has a pronounced relief the volume of the terrane above a plane through the outlet affords storage capacity for a considerable supply of water, and the water table in the higher tracts may attain a considerable altitude above the point of outlet. Therefore, in many areas the reductions in ground-water yield over long periods of drought may be comparatively small, as discussed on page 27 with reference to the Potomac River at Shepherdstown, W. Va.

Unfortunately, there are comparatively few long-time records of fluctuations of the water table, and most statements in regard to ground water in hydraulic studies are based more on generalized impressions than on observed data. False impressions of depletion may be gained by the necessity of deepening wells in periods of drought, by increased needs for water which require additional or deeper wells, and by leakage from casings, clogging of intakes, or filling of old wells.

In many sections of the country during the last few years precipitation and water-supply trends have been downward. Similar downward trends in the past have been followed by upward trends, and there is nothing to indicate that this will not apply to the present downward trend.

\section{GROUND WATER}

Owing to the deficiency in precipitation during the replenishment period of 1934 there was little or no recharge in the main drought areas, so that the available ground water was in a large measure that carried over from the preceding year. Consequently in large areas the ground-water table fell below the outlets of springs and 
the bottoms of streams and wells, thus materially cutting off its contribution to surface waters and to springs and wells.

Adequate data to indicate the extent to which the ground-water table was lowered in 1934 or whether there has been a progressive lowering during the past few years are not available, and any statements in this regard are largely conjecture. Although there may have been a progressive fall in some areas, there are no records to indicate that this is true to any great extent except where there has been heavy pumping for municipal or industrial supplies or for irrigation. The ground-water table in humid areas in general responds very quickly to fluctuations in rainfall (see pp. 22-26), and in most years there is enough rainfall to supply the normal recharge. The lowering of the ground-water table and the shortage in precipitation in the drought areas resulted in a noticeable lowering effect on stream flow, lakes, ponds, and reservoirs.

\section{SURFACE WATER}

The effect of the drought on stream flow was most noticeable in the upper Mississippi, Hudson Bay, Missouri, Colorado, and Great Basin drainage areas. In these areas many previous records of minimum flow were broken, both as to total annual flow and as to flow for shorter periods. Shortages in flow were also noticeable in the Great Lakes drainage basin, the Ohio River tributaries from the north, and the lower Mississippi River tributaries from the west, but comparatively few previous minima on these streams were exceeded. In the Atlantic coast and Gulf of Mexico drainage basins and also in the Pacific coast basins with the exception of portions of the Snake River, stream flow was in general normal. A few examples showing the effect of the drought of 1934 on stream flow in the principal drought areas are given in table 12 .

TABLE 12.-Effect of the drought of 1934 on stream flow in the principal drought areas

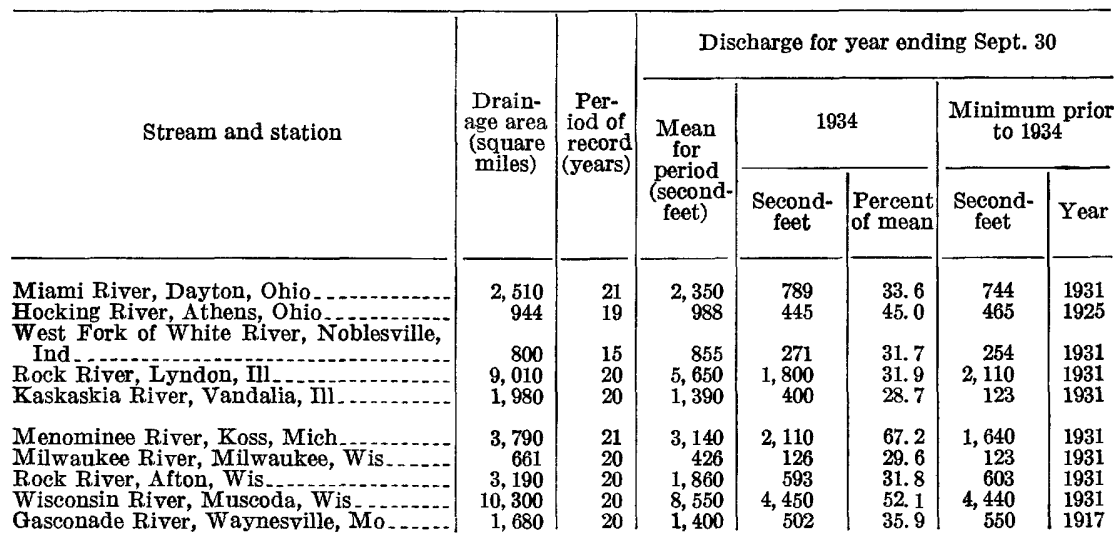


TABLE 12.-Effect of the drought of 1934 on stream flow in the principal drought areas-Continued

\begin{tabular}{|c|c|c|c|c|c|c|c|}
\hline \multirow{3}{*}{ Stream and station } & \multirow{3}{*}{$\begin{array}{l}\text { Drain- } \\
\text { age area } \\
\text { (square } \\
\text { miles) }\end{array}$} & \multirow{3}{*}{$\begin{array}{l}\text { Per- } \\
\text { iod of } \\
\text { record } \\
\text { (years) }\end{array}$} & \multicolumn{5}{|c|}{ Discharge for year ending Sept. 30} \\
\hline & & & \multirow{2}{*}{$\begin{array}{c}\text { Mean } \\
\text { for } \\
\text { period } \\
\text { (second- } \\
\text { feet) }\end{array}$} & \multicolumn{2}{|c|}{1934} & \multicolumn{2}{|c|}{$\begin{array}{c}\text { Minimum prior } \\
\text { to } 1934\end{array}$} \\
\hline & & & & $\begin{array}{l}\text { Second- } \\
\text { feet }\end{array}$ & $\begin{array}{l}\text { Percent } \\
\text { of mean }\end{array}$ & $\begin{array}{l}\text { Second- } \\
\text { feet }\end{array}$ & Year \\
\hline $\begin{array}{l}\text { Grand River, Gallatin, Mo } \\
\text { Missouri River, Mobridge, S. Dak. } \\
\text { Missouri River, Booneville, Mo } \\
\text { Minnesota River, Montevideo, Minn } \\
\text { Minnesota River, Mankato, Minn.... }\end{array}$ & $\begin{array}{r}2,250 \\
208,700 \\
505,700 \\
6,300 \\
14,600\end{array}$ & $\begin{array}{r}13 \\
6 \\
9 \\
25 \\
31\end{array}$ & $\begin{array}{r}1,110 \\
19,500 \\
58,000 \\
514 \\
2,320\end{array}$ & $\begin{array}{c}117 \\
13,700 \\
23,730 \\
4.4 \\
136\end{array}$ & $\begin{array}{r}10.4 \\
70.2 \\
40.9 \\
.9 \\
5.9\end{array}$ & $\begin{array}{c}360 \\
13,000 \\
31,800 \\
32.7 \\
291\end{array}$ & $\begin{array}{l}1931 \\
1931 \\
1931 \\
1933 \\
1931\end{array}$ \\
\hline $\begin{array}{l}\text { Mississippi River, Elk River, Minn } \\
\text { Mississippi River, St. Paul, Minn } \\
\text { Mississippi River, Le Claire, Iowa } \\
\text { Red River, Fargo, N. Dak } \\
\text { Red River, Grand Forks, N. Dak...... }\end{array}$ & $\begin{array}{r}14,500 \\
36,800 \\
88,600 \\
6,420 \\
25,500\end{array}$ & $\begin{array}{l}19 \\
42 \\
61 \\
32 \\
52\end{array}$ & $\begin{array}{r}4,270 \\
9,210 \\
48,200 \\
468 \\
2,260\end{array}$ & $\begin{array}{c}1,450 \\
1,940 \\
18,900 \\
17.5 \\
244\end{array}$ & $\begin{array}{r}33.9 \\
21.1 \\
39.2 \\
3.7 \\
10.8\end{array}$ & $\begin{array}{c}2,160 \\
3,190 \\
24,400 \\
41.7 \\
351\end{array}$ & $\begin{array}{l}1933 \\
1931 \\
1931 \\
1933 \\
1931\end{array}$ \\
\hline $\begin{array}{l}\text { North Platte River, Saratoga, Wyo } \\
\text { Bear River, Evanston, Wyo. } \\
\text { Rio Grande, Del Norte, Colo } \\
\text { Animas River, Durango, Colo. } \\
\text { Colorado River, Glenwood Springs, Colo. }\end{array}$ & $\begin{array}{r}2,880 \\
645 \\
1,320 \\
692 \\
4,560\end{array}$ & $\begin{array}{l}27 \\
21 \\
45 \\
33 \\
35\end{array}$ & $\begin{array}{r}1,330 \\
248 \\
978 \\
933 \\
3,070\end{array}$ & $\begin{array}{c}330 \\
50.8 \\
468 \\
345 \\
1,423\end{array}$ & $\begin{array}{l}24.8 \\
20.5 \\
47.9 \\
37.0 \\
46.4\end{array}$ & $\begin{array}{r}662 \\
105 \\
353 \\
402 \\
1,720\end{array}$ & $\begin{array}{l}1931 \\
1931 \\
1902 \\
1931 \\
1931\end{array}$ \\
\hline $\begin{array}{l}\text { Colorado River, Lees Ferry, Ariz } \\
\text { Weber River, Oakley, Utah, } \\
\text { Humboldt River, Palisade, Nev. }\end{array}$ & $\begin{array}{r}107,900 \\
163 \\
5,010\end{array}$ & $\begin{array}{l}40 \\
28 \\
26\end{array}$ & $\begin{array}{r}20,000 \\
246 \\
334\end{array}$ & $\begin{array}{l}6,050 \\
82.7 \\
34.8\end{array}$ & $\begin{array}{l}30.2 \\
33.6 \\
10.4\end{array}$ & $\begin{array}{l}8,600 \\
108 \\
51.1\end{array}$ & $\begin{array}{l}1931 \\
1931 \\
1931\end{array}$ \\
\hline
\end{tabular}

As Missouri was one of the States in which drought conditions in 1934 were severe, a summary of low-water conditions in this State is indicative of conditions in other major drought areas. At 9 of the 24 river-measurement stations maintained in that section of the State lying north of the Missouri River the flow ceased entirely for the first time since the beginning of records in 1921. New low-water records were established at 10 other stations. In the area south of the Missouri River conditions were not so critical, as the streams are largely springfed. Nevertheless, of the 43 stations in this area, 3 became dry, 23 established new minimum records, and at only 17 did the flow remain above the previous minimum.

In Idaho the year 1934 was characterized by the lowest run-off ever recorded on the Snake River. At Heise, above the upper-valley canals, the river run-off was 54 percent of normal, and at Neeley, below the American Falls Reservoir, it was 43 percent of normal. During 1931, when the next lowest flow on record occurred, the runoff was 58 percent of normal at Heise and 55 percent of normal at Neeley. Jackson Lake bottom storage rights were 52.6 percent filled, and American Falls rights 51.5 percent filled exclusive of holdovers from the previous year and stored normal flow.

Great Salt Lake reached an altitude of $4,194.85$ feet on September 30,1934 , the lowest recorded since observations were begun in 1851 . The next lowest level was recorded in 1902 and 1905, when the lake stood at 4,195.7 feet. The maximum recorded stage was $4,212.5$ feet in 1868 . 
In the arid and semiarid parts of the country the lowering of lakes, ponds, and reservoirs was so great that in many localities they dried up entirely or were exhausted by excessive demands for irrigation and other uses. During the year 1934 the net reduction in storage in 24 reservoirs of the United States Bureau of Reclamation with an aggregate capacity of $12,000,000$ acre-feet was $2,170,000$ acre-feet, as indicated in table 13.

TABLE 13.-Water in storage in 24 reservoirs of $U$. S. Bureau of Reclamation on Dec. $31,1929-34$

\begin{tabular}{|c|c|c|c|c|c|}
\hline & $\begin{array}{l}\text { Acre-feet } \\
\text { in storage }\end{array}$ & $\begin{array}{l}\text { Change from } \\
\text { previous year }\end{array}$ & & $\begin{array}{l}\text { Acre-feet } \\
\text { in storage }\end{array}$ & $\begin{array}{l}\text { Change from } \\
\text { previous year }\end{array}$ \\
\hline 1929 & $\begin{array}{l}4,590,000 \\
3,880,000 \\
2,380,000\end{array}$ & $\begin{array}{r}-710,000 \\
-1,500,000\end{array}$ & $\begin{array}{l}1932 \\
1933- \\
1934\end{array}$ & $\begin{array}{l}5,160,000 \\
4,640,000 \\
2,470,000\end{array}$ & $\begin{array}{l}+2,780,000 \\
-620,000 \\
-2,170,000\end{array}$ \\
\hline
\end{tabular}

\section{DAMAGE}

The drought of 1934 covered one of the principal agricultural areas of the country, and in the main the damage it caused relates to agriculture. In the area in which the drought was most severe, precipitation and resulting water supplies are meager, and therefore shortages are much more noticeable and their effects more serious than in the humid areas. Much of the drought damage would not have resulted if there had been a proper coordination between available supplies and the activities that depend upon water. Complete information in regard to damages is not available, but the following paragraphs give a general idea of their extent.

\section{VEGETATION}

Miscellaneous reports based on personal observation indicate that during 1934 in the major drought area most types of natural vegetation, especially trees that have deep roots and draw their water from levels near the ground-water table, suffered in varying degrees. It was also observed in the semiarid sections that natural perennial grasses, which were the basis for stock raising in the early days, were in considerable measure drought-resistant. This emphasizes the fact that natural vegetation adjusts itself through the centuries to extremes of climate.

The effects of the drought of 1934 on cultivated vegetation were widespread and in many areas were serious.

In the humid areas the sections affected were limited, in the main, to States in the upper Mississippi, Ohio, and Great Lakes drainage basins, and to Arkansas. The effects were very spotted and were most severe in Minnesota, Iowa, Illinois, Missouri, and Arkansas. In many sections there was sufficient precipitation to mature lateplanted forage crops, which greatly relieved the shortage of stock feed. 
The effects of the drought were most serious in the semiarid States, where all known conditions unfavorable to vegetable growth existeddeficient total precipitation with unfavorable distribution, extremes in temperature, and hot winds. As indicated in table 11, precipitation during the first two quarters of the year was deficient. As a result the growing season started with too little soil moisture for proper crop germination. This was followed in many areas by deficient precipitation during the growing season, which, combined with excessive temperature and hot winds, was disastrous to much vegetation, especially in the Dakotas.

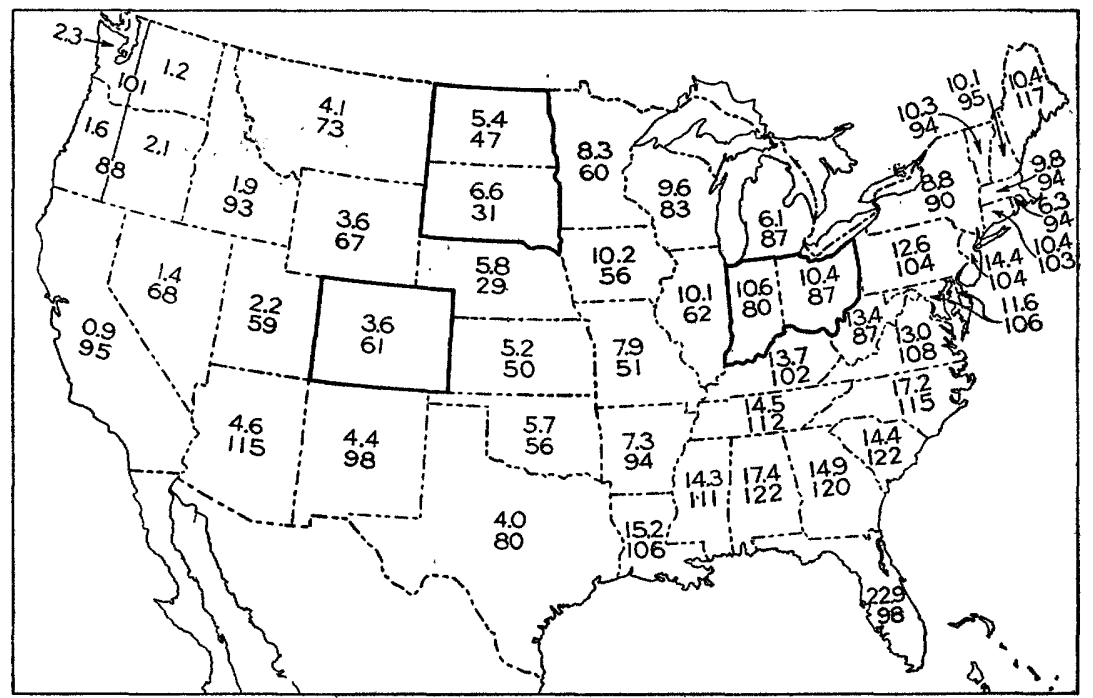

Froure 18.-Total precipitation for June, July, and August (upper figures) and composite yields of erops per acre expressed as percentage of average yields (lower figures), 1934. In areas indicated by heary outline the precipitation in 1934 was the lowest of record.

The conditions that prevailed in the arid sections during 1934 are described in the November report of the Bureau of Reclamation as follows:

The crop results have been surprisingly favorable in view of the widespread shortage of water and the early predictions of crop losses. Well-organized plans of conservation have in a great measure alleviated the threatened losses on projects with limited supplies on hand. On the Carlsbad project, in New Mexico, and in the Imperial Valley, Calif., however, heavy crop losses were experienced by lack of water. Moderate crop losses occurred on the Truckee division of the Newlands project in Nevada, the Strawberry project in Utah, the Minidoka and Boise projects in Idaho, and the North Platte project in Wyoming, where the storage during the past year was very low and summer flows were far below normal. Except on those projects mentioned above, where water has been extremely deficient, crop returns have been excellent.

These results were duplicated on many non-Federal projects and illustrate what can be accomplished with adequate storage and wise 
use of water. Many smaller projects that had insufficient storage or did not reduce their acreage or irrigate under the demand system suffered severely in 1934. The areas most affected were in the Great Basin and in areas supplied by water from the Colorado River drainage basin.

Although it is difficult to differentiate the relative magnitude of the effects of the many complex factors entering into the status of agriculture of which drought is only one, crop statistics give an indication of drought effect. The United States general crop report of December 1934 estimated the combined yield per acre of 33 important crops as 81.2 percent of the 10-year average yield (1921-30).

The crop yields by States and the precipitation for the growing months, June, July, and August, are indicated in table 11 and figure 18. The lower numbers in figure 18 show that in 17 States the yield per acre was more than 100 percent of the 10-year average, in 9 between 90 and 100 percent, in 7 between 80 and 90 percent, and in 15 below 80 percent. These figures do not reflect the total loss due to the drought, because acreage entirely abandoned is not included in the computation. Except in Wisconsin, Indiana, and Mlinois there were no serious effects on yields in the humid States east of the Mississippi River. Noticeable shortages occurred in the humid States west of the Mississippi except Louisiana and Arkansas and in all the arid and semiarid States except New Mexico, Arizona, Idaho, Washington, Oregon, and California. The lowest yields were in the semiarid States, except Texas, and in Minnesota, Iowa, Missouri, and Illinois on the east, and Montana, Wyoming, Colorado, Utah, and Nevada on the west. The drought area included much of the corn belt, and the yield of corn for the country as a whole was only 60.5 percent of the 10-year average. The other staple crops most affected were small grains and hay. The yield of winter wheat was 83.7 percent of the average, and of spring wheat 79.1 percent, but for cotton, potatoes, and tobacco, three other important money crops, yields were above normal. These figures represent the yields per acre and not the total crop production, which for the more staple crops was unusually low for the country as a whole. The low total production resulted both from low yields due to unfavorable growing conditions and from reduction in acreage, which was about 20 percent less than in 1932 and 12 percent less than in 1933. The shortages, however, were not great enough to have a serious effect on the country's total food supply, and the total returns for crops were the highest since 1929 , being estimated at $\$ 4,764,507,000$, or about 70 percent more than in 1932 and 19 percent more than in 1933.

Attention has been called by the Division of Grazing, Department of the Interior, to the importance of the grass crop in the land eco- 
nomics of the country. The value of this crop is not included in the statistics given above, except as a very small percentage is allowed for dry and harvested hay. Reports indicate that in the United States $1,055,000,000$ acres, or 55 percent of the entire country, is in grass land. Grass produces half of all the feed for all livestock and is the greatest single crop in area, value, and tonnage. More than half of the above-stated acreage of pasture land is in the arid and semiarid States. Only one-tenth of our pasture land is arable, but that onetenth has a carrying capacity five times as great as the natural pasture.

The effect of drought on pasture land is threefold-to the grass, to the stock, and to the land itself. Less precipitation means less feed, but as the number of stock is more or less constant, overgrazing is the result and may be carried to a point where the vegetable species most palatable to stock are either partly or wholly destroyed. The drying up of water supplies used by stock means a decreased area of grazing and results in intensified grazing adjacent to the remaining water supplies. This aggravates damage to stock, vegetation, and land.

\section{DOMESTIC AND INDUSTRIAL WATER SUPPLIES}

The experience gained during the drought of 1930 and 1931 led to a material extension throughout the country of facilities for conserving and providing water. As a result, the shortages of water for domestic and industrial uses during the drought of 1934 were in most areas much less than during previous droughts.

In the humid regions there were practically no serious shortages except in States bordering on the Mississippi River-especially Missouri and Iowa. The shortages were primarily in the rural section and smaller towns, as most cities and larger towns are now provided with adequate water supplies. In most sections the situation was he!ped by deepening wells and clearing streams, but in some sections hauling of water was necessary.

In the early stages of the drought the State geologist of Missouri foresaw the possibility of water shortages in the rural sections and directed the necessary geologic surveys for determining the possibilities of the development of underground water throughout the State. These surveys indicated the most favorable locations for wells, and as a result additional supplies were provided throughout the State, so that serious shortages were, in the main, averted. The surveys will also be of great value in the development of adequate water supplies for the future, and they indicate what can be done in other sections.

In the rural portions of the semiarid regions serious shortages were experienced on account of the failure of shallow wells and the drying up of ponds, lakes, and small streams. The urban supplies of these regions, which in the main come from deep wells and the larger streams, were adequate in most localities, although in some areas it. 
was necessary to curtail consumption and develop additional supplies. Shortages were especially noticeable in the Red River drainage basin of Minnesota and North Dakota.

In the irrigated areas of the arid regions water supplies for domestic, stock, and industrial uses are often developed in connection with irrigation systems. During 1934 shortages of suitable water for these uses were common and caused considerable inconvenience, especiatly on the smaller irrigation projects. In many localities it was necessary to curtail the use of the water and in some sections to develop supplementary supplies. On most of the larger irrigation projects there were no serious shortages for nonirrigation uses, although supplying the requirements for such uses necessitated an uneconomical operation of the ditches and thus resulted in considerable waste.

The shortage of irrigation water on the Snake River in southern Idaho during 1934 has resulted in a study, now under way, for eliminating winter diversions of water for domestic purposes in that area. It is suggested that wells be drilled to furnish domestic water under all canals, at a cost of $\$ 2,250,000$. This expenditure will result in adding about 450,000 acre-feet annually to the winter supply available for storage in existing reservoirs that do not fill in the dry years.

Curtailment of the use of water was necessary in most of the larger towns of the arid regions. In some towns deficiencies were overcome by the development of additional supplies. In Salt Lake City, which has a normal summer demand of about 60 second-feet, shortages developed early in the summer. A detailed ground-water investigation under way by the United States Geological Survey in cooperation with the city was utilized to determine the possibilities of obtaining an additional supply, and as a result wells were drilled which yielded 52 second-feet of water. These wells were pumped as needed to take care of exchange agreements by the city and to furnish a direct supply to city consumers. As a result of careful use the city consumption during September amounted to only 44 second-feet, of which 26 second-feet was well water.

\section{HEAITH}

According to the following statement of the Surgeon General of the Bureau of Public Health Service, ${ }^{13}$ the drought during 1934 had no large effect upon general health.

It may be that the drought had an effect on the health of persons who were subjected to unusual conditions, but figures that will prove or disprove this are not now available. Even when detailed figures for all States have been compiled it will probably be impossible to separate the effect of the drought from the results of numerous other causes : which affect health. Data on deaths: for the year 1934 have not yet been collected.

1s Personal communication. 
During the summer of 1934 there was an increase in the reported prevalence of typhoid fever in some of the drought-stricken States. It is probable that some of the increase shown is due to contamination of water supplies, but in some States the apparent increase in number of cases may have been the result of efforts to secure more nearly complete reporting of cases, which have been carried on for several years.

\section{POWER}

A comparison of the amount of electricity produced in 1933 and 1934 for public use in the West North Central States. (Minnesota, Iowa, North Dakota, South Dakota, Nebraska, and Missouri) indicates that the drought of 1934 had considerable effect on the production of electricity by the use of water power in that area. Although there was an increase of 4 percent in the total production of electricity from 1933 to 1934 in these States, the amount of electricity produced by water power decreased 21 percent.

\section{NAVIGATION}

The Chief of Engineers, United States Army, ${ }^{14}$ has furnished the following statement in regard to the effect of the drought on navigation:

It would be extremely difficult to evaluate the additional expenditures necessitated by the low-water conditions during the season of 1934, although it is certain that there was some increased dredging necessary in maintaining project depths in the affected region. The low water was particularly felt in the movement of traffic on the upper Mississippi River, as it made it impossible to maintain the project depth of 6 feet at Horse Island, even by release of an additional water supply from pool 15, at Rock Island, Ill.

As a result of the low-water conditions on the upper Mississippi River, the Inland Waterways Corporation, on August 31, 1934, issued an embargo against all freight to and from or via points located on the Mississippi River north of the mouth of the Illinois River, except on cement destined to Guttenberg, Iowa, via Dubuque, Iowa. This embargo was maintained until improved flow conditions permitted its lifting on Oetaber 4.

\section{RECREATION AND WMD IHWE}

Recreational activities in the drought States were much interfered with during 1934 by the drying up of both natural and artificial lakes. This also had a detrimental effect on wild life, and as a relief measure many lakes ranging in size from about 80 to 10,000 acres were developed in the drought States for recreational use and for bird refuges. The bird refuges were developed on public land entirely at public expense. In the development of the recreational lakes the local people contributed by furnishing the site and all or part of the material and equipment required for the work. Work of this type not only provided effective relief but appealed especially to residents of the semiarid States, where there are few if any bodies of water available for recreational use or for migratory birds.

1s Personal communication. 


\section{RELIEF}

For several years there have been demands for relief in many areas due to unfavorable agricultural and other conditions; therefore it is difficult to differentiate the part of the demands in 1934 that were directly traceable to the drought.

In June 1934 Congress made available to the Federal Emergency Relief Administration the sum of $\$ 525,000,000$ to be expended on drought relief in areas designated by the United States Department of Agriculture as suffering from drought, the funds to remain available until March 31, 1935. The Federal Emergency Relief Administration allotted these funds to the various State emergency relief administrations in the drought area, to be expended by these agencies under general policies established by the Federal Administration.

The program as carried out has included all types of relief, such as direct payment of funds to distressed families, the purchase of livestock that could not be maintained in the drought area because of shortage of feed and water, the furnishing of seed for late forage crops, etc., and work projects, such as the processing and canning of meats for distribution to people on relief rolls and the development of water supplies in the drought areas.

That part of the drought relief program which relates to the development of water supplies included the following items:

\footnotetext{
Cleaning of springs

Wells for domestic use

Wells for stock water

Wells for municipal water supply

Pumping for stock or domestic use

Pumping for irrigation

Dam for stock water

Dam for irrigation water

Dam for recreational lake
}

\begin{tabular}{|l} 
Dam for wild-life refuge \\
Maintenance ditches \\
Reservoir outlet \\
Reservoir repair work \\
Tapping or lowering a lake \\
Draining a slough, etc. \\
Hauling water for stock \\
Hauling water for domestic use
\end{tabular}

The work under these items is described in a paper by Lewis $A$. Jones, staff engineer, F. E. R. A., presented at the meeting of the Engineering Institute of Canada, Toronto, February 7, 1935, in part. as follows:

Because of the comparatively short time the drought relief funds would be available and the urgent need in many areas for immediate water supplies, it was decided in planning the water program to limit the work to projects that would promptly make water available and that could be completed within the limited time during which drought funds would be available. In other words, the object was to meet the existing drought situation rather than to start on a long-time water-conservation program.

On the national-forest ranges and public grazing land the work has been confined largely to the cleaning out and improvement of springs, the digging of wells, the furnishing of windmills and tanks, and the construction of dams to form stock water holes. The improvements are more or less of a permanent nature, and the increased carrying capacity of the range resulting from the work will ultimately pay the cost. 
On privately owned land, both in the range and dry-farming areas, the same types of projects have been carried on, but in every case, before construction work has been started, the landowner has been required to sign an easement granting the general public access to the water developed during periods of drought.

In the irrigated areas ditches have been cleaned out and lined to reduce seepage losses, reservoirs and other irrigation structures have been repaired, small reservoirs have been constructed, and pumping from streams has been carried on to furnish supplemental water for crops. This work has resulted in the saving of large areas of crops that would have otherwise been killed by the drought and has enabled the landowners to take care of themselves during this winter instead of being dependent upon the relief rolls. The cost of carrying the benefited people over the winter on the relief rolls would have in most cases exceeded very materially the cost of the work, and the landowners have been able to maintain their self-respect.

In some instances the water supplies for towns and villages have been supplemented by the digging of wells, the improvement of reservoirs, the construction of pipe lines, and the pumping of water from nearby streams, etc. In practically all cases where assistance has been rendered to incorporated towns the local communities have been required to furnish most of the materials required for the work, and the drought funds have been expended in the employment of labor that would otherwise have been on the relief rolls.

In a few of the drought States bird refuges and recreational lakes have been developed as a phase of the relief work, the size of the lakes varying in area from about 80 to 10,000 acres. The bird refuges have been developed on publio lands and entirely at public expense. In developing the recreational lakes the local people have been required to furnish the lake site and all or part of the materials and equipment required for the work. The relief funds have been devoted primarily to the employment of labor from the relief rolls. In visiting the field the writer has been impressed with the popularity of such developments. They appeal especially to the residents of the semiarid States, where bodies of water for recreational uses are nonexistent.

In addition to the construction projects outlined above a number of the State relief administrations have conducted ground- and surface-water surveys to determine the extent of such resources. Such projects have furnished employment to engineers and geologists in need, and the results obtained will be of great value in planning long-time programs of water conservation. Several of the States have established water-conservation boards, and the State relief administrations have cooperated with these boards by furnishing technical personnel to assist in developing State-wide plans for water development. If a general public-works program should be undertaken the plans that have been prepared will be of great value in expediting the work.

In Montana the water program has been limited primarily to the development of water supplies on the range lands. Numerous springs have been cleaned out and equipped with suitable water troughs; wells have been dug; and small dams constructed to form stock water ponds. As a result of the work it has been possible to retain a large amount of livestock in the State that would otherwise had to have been sacrificed. In some instances supplemental water has been made available to irrigated lands and repairs made to irrigation systems to reduce seepage losses. Assistance has also been rendered to the State Conservation Board by furnishing employment to technical employees engaged in developing a long-time plan of water development and conservation for the State.

In North Dakota work in the rural region has been limited primarily to the construction of dams for stock water ponds. It is expected that more than $\mathbf{4 0 0}$ 
such dams will be completed before the end of next March. In addition to the stock water ponds a considerable number of small recreational lakes and municipal reservoirs have been completed ranging in size from 30 to 40 acres up to 600 or 700 acres. Five large bird refuges are also under construction covering a total of more than 150,000 acres. The refuges on the Des Lacs Lakes and the Souris River, located north of Minot, are expected, when completed, to be the most valuable wildlife refuges in the United States. In localities where municipalities and rural communities have suffered from shortage of water, wells have been dug to relieve the situation.

The State has organized a water conservation board, and the Emergency Relief Administration has cooperated with the board by furnishing technical personnel from the unemployed lists to conduct a State-wide survey of groundwater conditions which will be of value in planning a water-development program for the State.

The Federal Emergency Relief Administration feels that the water development and conservation projects carried on under the drought-relief program have not only been of great value in relieving the immediate drought situation but that much of the work is of such permanent character that benefits will continue to be derived for years to come. The value of the crops and livestock saved during the past season have enabled large numbers of farmers to maintain themselves who otherwise would have had to appeal for relief during the present winter. The reduction thus obtained in the relief load will go a long way toward paying the cost of the work. The program has also provided an opportunity for work to large numbers on the relief rolls, thus enabling them to maintain their self-respect by working instead of accepting a dole.

Several projects were undertaken in Idaho by drought-relief agencies set up by the Government. About 17,000 acre-feet of water was made available by the draining of several lakes and by pumping and was distributed by a local committee to water users on Henrys Fork and its tributaries. A section of an old power dam near Woodville was torn out, reducing the size of a ponded area and decreasing losses that were occurring. Several wells were drilled by droughtrelief funds in the Blackfoot-Aberdeen section and furnished small supplies for local irrigation. Money from the same source was used to drill wells and build cisterns in the Jerome-Twin Falls area, to assist in providing domestic water, so that use of winter water from irrigation ditches may eventually be abandoned in that area. The Utah Power \& Light Co. made available to Henrys Fork canals, without cost, 1,000 acre-feet of water by reducing the operating head in the forebay at its Ashton plant.

The funds allocated to the various States from the $\$ 525,000,000$ authorized by Congress through March 19, 1935, are indicated below. These amounts include the allocations to the Federal Surplus Relief Corporation for activities in connection with the drought, and in some States they extend to nondrought areas. They do not, however, include allotments to the Farm Credit Association, Civilian Conservation Corps, Agricultural Adjustment Administration, or land purchase program for their activities as related to the drought. 


\begin{tabular}{|c|c|c|c|}
\hline 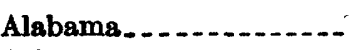 & & w Jersey . . . . & \\
\hline rizona & $2,069,000$ & ew Mexico & \\
\hline rkansas _. & & ew York ........... & \\
\hline lifomin & & Torth Carolina........ & \\
\hline$-2-2-2-1$ & & orth Dakota........... & 13, \\
\hline t. & & n & \\
\hline - & & homa. & \\
\hline Columbia_...- & & & \\
\hline$\ldots \ldots$ & 2,28 & .......... & 1,51 \\
\hline$--1-2-1-n$ & & $\ldots-\ldots$ & 200 \\
\hline - & & an_....... & \\
\hline - & & a......... & 15, \\
\hline & 2,0 & & 1,2 \\
\hline ( & 4,6 & $8 \ldots \ldots$ & 28,0 \\
\hline 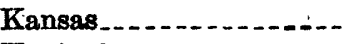 & 0 & $n-1-2-1-2-1$ & 6,38 \\
\hline$y=$ & & at............... & \\
\hline & 1,2 & & 1,27 \\
\hline & & 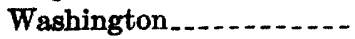 & \\
\hline 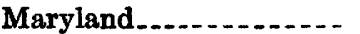 & 1,4 & $a_{\ldots} \ldots$ & \\
\hline ts.......... & & (n) & 5,9 \\
\hline & 2,1 & $x_{0}$ & 3,58 \\
\hline 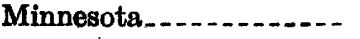 & 10,77 & & \\
\hline 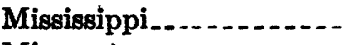 & 1,1 & Virgin Islands........ & 15,000 \\
\hline$------\infty-\infty$ & 11,48 & & \\
\hline & 7,28 & & 212,22 \\
\hline ebraska............. & $6,860,000$ & Federal allotment.....- & $1,000,000$ \\
\hline $\begin{array}{l}\text { Nevada } \\
\text { New Hampshire }\end{array}$ & $\begin{array}{r}1,401,000 \\
79,300\end{array}$ & & [3 \\
\hline
\end{tabular}

\section{COMPaRison OF DROUGHTS DURING PERIOD 1881 TO 1934}

Records of precipitation and stream flow give an index for comparing droughts in their physical aspects and will generally serve to answer questions relative to frequency, duration, extent of area covered, and severity. Additional facts, however, which are usually lacking, are needed in considering the nature and extent of the economic effects.

Precipitation records of the United States Weather Bureau, which are on a comparable basis by States since 1880, are given in tables 1. and 14.

They indicate that in the humid States annual fluctuations are relatively large in amount but comparatively small in percentage of the mean, seldom exceeding 15 percent. In the semiarid and arid States, however, fluctuations in percent of mean are wider and annual deficiencies ranging from 20 to 45 percent are not unusual. Any comparisons based on State annuals for the arid States may be misleading, because of the wide range of precipitation in various parts of the individual States. In the humid and semiarid States, except Texas, the State distribution is more uniform. 
The number of years in the period 1881 to 1934 when the precipitation did not exceed 85, 80, 75 and 70 percent of the mean-that is, a deficiency of $15,20,25$, and 30 percent or more-are given for each State in table 15, which also gives the precipitation for the 6 years during the same period when it was lowest in each State, arranged in order of magnitude of deficiency from lowest to highest. In a few States there were less than 6 years in which precipitation was as low as 85 percent.

Under the criterion that a drought exists when the precipitation falls to 85 percent of the mean, since 1880 there have been 38 drought years in the humid States and 28 in the semiarid States, as indicated in figure 19 and table 14, which also give for the various years in both groups of States the percentage of the area in which there was this deficiency, and the precipitation in percentage of the mean for that area. Table 16 lists for both the humid and semiarid. States the 14 worst drought years, arranged both according to magnitude of area affected and chronologically. Plate 1 indicates the States that were affected during the 7 worst drought years for the humid and semiarid States. In some years droughts were common for both groups of States, and in other years only one group was affected.

TABLE 16.-Years when large areas of the humid and semiarid States had deficiency in precipitation of 15 percent or more

Humid States

\begin{tabular}{|c|c|c|c|c|c|c|}
\hline \multirow[b]{2}{*}{ No. } & \multicolumn{3}{|c|}{ In order of extent } & \multicolumn{3}{|c|}{ In chronological order } \\
\hline & Year & $\begin{array}{c}\text { Ares } \\
\text { affected } \\
\text { (percent) }\end{array}$ & $\begin{array}{l}\text { Precipita- } \\
\text { tion in are a } \\
\text { of defi- } \\
\text { ciency } \\
\text { (percent } \\
\text { of mean) }\end{array}$ & Year & $\begin{array}{c}\text { Interval } \\
\text { between } \\
\text { deficiency } \\
\text { (years) }\end{array}$ & $\begin{array}{l}\text { Order of } \\
\text { extent } \\
\text { of area } \\
\text { affected }\end{array}$ \\
\hline 11 & $\begin{array}{l}1930 \\
1894 \\
1901 \\
1934 \\
1889 \\
1910 \\
1917 \\
1921 \\
1925 \\
1904 \\
1895 \\
1993 \\
1896 \\
1931\end{array}$ & $\begin{array}{l}63 \\
45 \\
34 \\
32 \\
32 \\
30 \\
30 \\
30 \\
30 \\
29 \\
27 \\
24 \\
18 \\
18\end{array}$ & $\begin{array}{r}74 \\
80 \\
75 \\
86 \\
77 \\
72 \\
80 \\
84 \\
80 \\
78 \\
77 \\
80 \\
82 \\
79\end{array}$ & $\begin{array}{l}1889 \\
1894 \\
1895 \\
1896 \\
1901 \\
1904 \\
1910 \\
1917 \\
1921 \\
1925 \\
1930 \\
1931 \\
1933 \\
1934\end{array}$ & $\begin{array}{r}5 \\
1 \\
1 \\
5 \\
3 \\
6 \\
7 \\
4 \\
4 \\
5 \\
1 \\
2 \\
1\end{array}$ & $\begin{array}{r}5 \\
2 \\
11 \\
13 \\
3 \\
10 \\
6 \\
7 \\
8 \\
9 \\
1 \\
14 \\
12 \\
4\end{array}$ \\
\hline
\end{tabular}

Semiarid States a

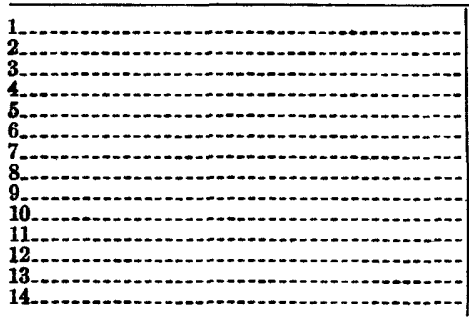

\begin{tabular}{|r|r|}
\hline 1934 & 100 \\
1910 & 100 \\
1894 & 80 \\
1917 & 78 \\
1890 & 68 \\
1933 & 66 \\
1931 & . 65 \\
1888 & 57 \\
1893 & \\
1895 & 57 \\
1913 & 45 \\
1887 & 44 \\
1901 & 35 \\
1914 & \\
\hline
\end{tabular}

\begin{tabular}{r|r}
\hline 100 & 65 \\
100 & 71 \\
80 & 70 \\
78 & 71 \\
68 & 76 \\
66 & 77 \\
65 & 80 \\
57 & 82 \\
57 & 7 \\
45 & 78 \\
44 & 8 \\
35 & 8 \\
35 & 75 \\
35 & \\
\hline
\end{tabular}

\begin{tabular}{r|r|r|r}
65 & 1887 & 12 \\
71 & 1888 & 1 & 8 \\
70 & 1890 & 2 & 5 \\
71 & 1893 & 3 & 9 \\
76 & 1894 & 1 & 3 \\
77 & 1895 & 1 & 10 \\
80 & 1901 & 6 & 13 \\
82 & 1910 & 9 & 2 \\
74 & 1913 & 3 & 11 \\
78 & 1914 & 1 & 14 \\
84 & 1917 & 3 & 4 \\
85 & 1931 & 14 & 7 \\
75 & 1933 & 2 & 6 \\
83 & 1934 & 1 & 1 \\
\hline
\end{tabular}

- North Dakota, South Dakota, Nebraska, Kansas; ғand Oklahoma. 
TABLE 14.-Annual precipitation in percent of mean, by States, 1881-1994

(n)

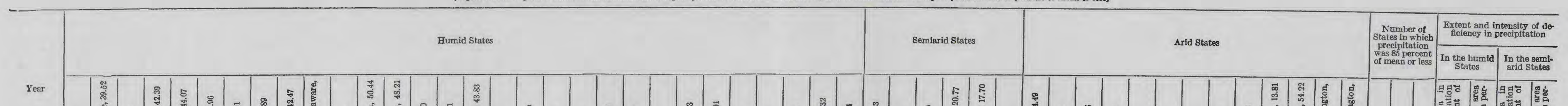

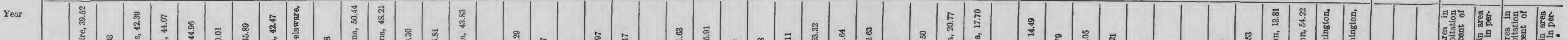

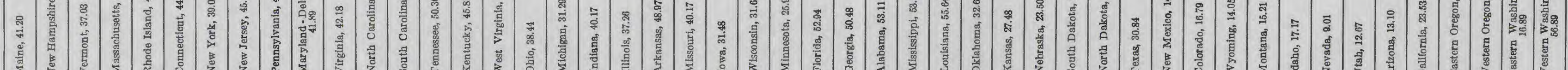

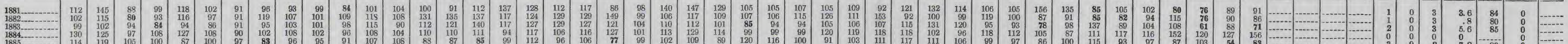

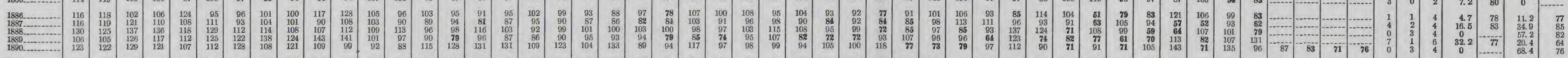

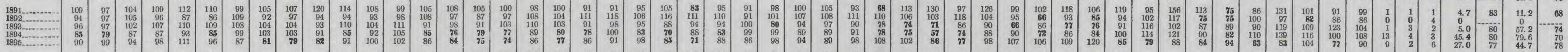

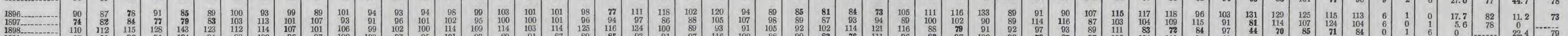

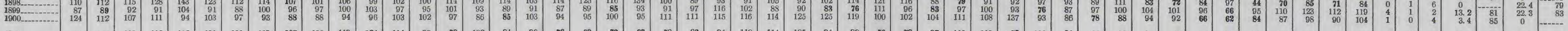

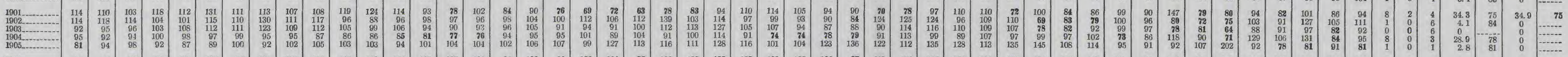

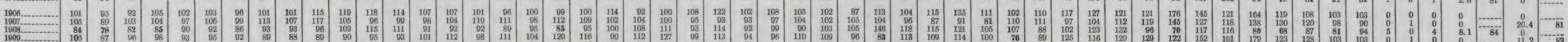

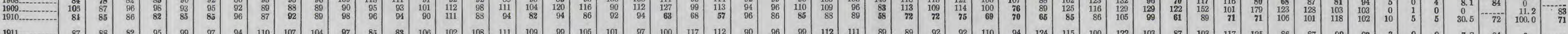

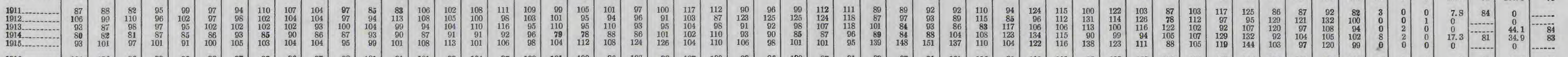

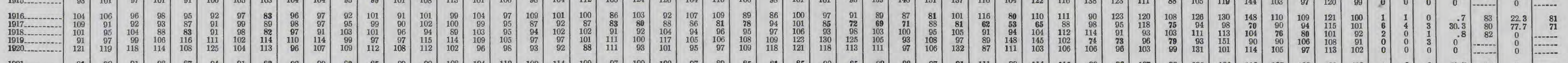

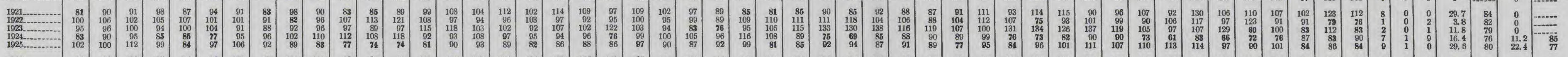

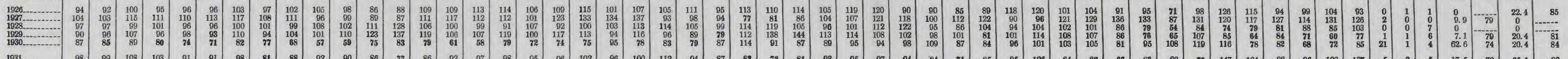

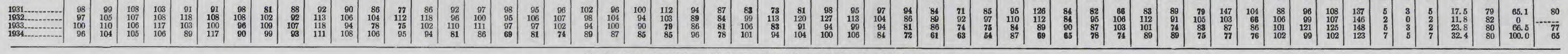




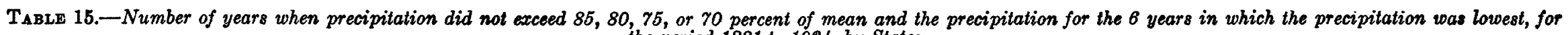
the period 1881 to 1984 , by States

\begin{tabular}{|c|c|c|c|c|c|c|c|c|c|c|c|c|c|c|c|c|c|c|c|c|c|c|c|}
\hline \multirow{3}{*}{ State } & \multirow{3}{*}{$\begin{array}{c}50 \text {-year } \\
\text { mean, } \\
1881-1930 \\
\text { (inches) }\end{array}$} & \multicolumn{3}{|c|}{1} & \multicolumn{3}{|c|}{2} & \multicolumn{3}{|c|}{3} & \multicolumn{3}{|c|}{4} & \multicolumn{3}{|c|}{$\mathbf{b}$} & \multicolumn{3}{|c|}{6} & \multirow{2}{*}{\multicolumn{4}{|c|}{$\begin{array}{l}\text { Number of years when } \\
\text { precipitation did not } \\
\text { exceed the following } \\
\text { percentage of mean }\end{array}$}} \\
\hline & & \multirow{2}{*}{ Date } & \multicolumn{2}{|c|}{ Precipitation } & \multirow[b]{2}{*}{ Dato } & \multicolumn{2}{|c|}{ Precipitation } & \multirow[b]{2}{*}{ Date } & \multicolumn{2}{|c|}{ Procipitation } & \multirow[b]{2}{*}{ Date } & \multicolumn{2}{|c|}{ Precipitation } & \multirow[b]{2}{*}{ Date } & \multicolumn{2}{|c|}{ Preclpitation } & \multirow[b]{2}{*}{ Date } & \multicolumn{2}{|c|}{ Precipitation } & & & & \\
\hline & & & Inches & $\begin{array}{c}\text { Percent } \\
\text { of mean }\end{array}$ & & Inches & $\begin{array}{l}\text { Percent } \\
\text { of mean }\end{array} \mid$ & & Inches & $\begin{array}{l}\text { Percent } \\
\text { of mean }\end{array}$ & & Inches & $\begin{array}{l}\text { Percent } \\
\text { of mean }\end{array}$ & & Inches & $\begin{array}{l}\text { Percent } \\
\text { of mean }\end{array}$ & & Inches & $\left|\begin{array}{c}\text { Percent } \\
\text { of mean }\end{array}\right|$ & 85 & 80 & 75 & 70 \\
\hline 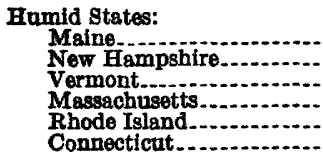 & $\begin{array}{l}41.20 \\
39.52 \\
37.03 \\
42.39 \\
44.07 \\
44.96\end{array}$ & $\begin{array}{l}1897 \\
1908 \\
1896 \\
1897 \\
1930 \\
1930\end{array}$ & $\begin{array}{l}30.60 \\
33.76 \\
28.78 \\
32.43 \\
32.83 \\
32.02\end{array}$ & $\begin{array}{l}74 \\
78 \\
78 \\
77 \\
74 \\
71\end{array}$ & $\begin{array}{l}1914 \\
1894 \\
1882 \\
1930 \\
1897 \\
1924\end{array}$ & $\begin{array}{l}32.98 \\
31.38 \\
29.67 \\
33.84 \\
34.60 \\
34.84\end{array}$ & $\begin{array}{l}80 \\
79 \\
80 \\
80 \\
79 \\
77\end{array}$ & $\begin{array}{l}1905 \\
1899 \\
1914 \\
1910 \\
1918 \\
1897\end{array}$ & $\begin{array}{l}33.23 \\
31.66 \\
30.16 \\
34.96 \\
36.57 \\
37.50\end{array}$ & $\begin{array}{l}81 \\
80 \\
81 \\
82 \\
83 \\
83\end{array}$ & $\begin{array}{l}1921 \\
1897 \\
1908 \\
1883 \\
1925 \\
1894\end{array}$ & $\begin{array}{l}33.55 \\
32.33 \\
30.24 \\
35.77 \\
37.20 \\
38.01\end{array}$ & $\begin{array}{l}81 \\
82 \\
82 \\
84 \\
84 \\
85\end{array}$ & $\begin{array}{l}1924 \\
1914 \\
1911 \\
1908 \\
1896 \\
1910\end{array}$ & $\begin{array}{l}34.37 \\
32.58 \\
30.54 \\
36.04 \\
37.25 \\
38.33\end{array}$ & $\begin{array}{l}83 \\
82 \\
82 \\
85 \\
85 \\
85\end{array}$ & $\begin{array}{l}1910 \\
1910 \\
1897 \\
1924 \\
1924 \\
1914\end{array}$ & $\begin{array}{l}34.51 \\
33.41 \\
31.18 \\
36.08 \\
37.46 \\
38.44\end{array}$ & $\begin{array}{l}84 \\
85 \\
84 \\
85 \\
85 \\
85\end{array}$ & $\begin{array}{l}8 \\
7 \\
6 \\
6 \\
8 \\
5\end{array}$ & $\begin{array}{l}2 \\
3 \\
2 \\
2 \\
2 \\
2 \\
2\end{array}$ & $\begin{array}{l}1 \\
0 \\
0 \\
0 \\
1 \\
1\end{array}$ & $\begin{array}{l}0 \\
0 \\
0 \\
0 \\
0 \\
0\end{array}$ \\
\hline $\begin{array}{l}\text { New York } \\
\text { New Jorsey } \\
\text { Pennsylvania } \\
\text { Maryland-Delaware } \\
\text { Virglinia } \\
\text { North Carolina }\end{array}$ & $\begin{array}{l}39.01 \\
45.89 \\
42.47 \\
41.89 \\
42.18 \\
50.44\end{array}$ & $\begin{array}{l}1930 \\
1930 \\
1930 \\
1930 \\
1930 \\
1925\end{array}$ & $\begin{array}{l}32.18 \\
36.28 \\
28.82 \\
23.78 \\
24.99 \\
37.33\end{array}$ & $\begin{array}{l}82 \\
77 \\
68 \\
57 \\
59 \\
74\end{array}$ & $\begin{array}{l}1908 \\
1981 \\
1895 \\
1895 \\
1925 \\
1930\end{array}$ & $\begin{array}{l}33.54 \\
37.07 \\
33.51 \\
34.47 \\
32.53 \\
38.04\end{array}$ & $\begin{array}{l}86 \\
81 \\
79 \\
82 \\
77 \\
75\end{array}$ & $\begin{array}{l}1895 \\
1895 \\
1922 \\
1925 \\
1921 \\
1933\end{array}$ & $\begin{array}{l}33.89 \\
37.29 \\
34.88 \\
34.91 \\
34.94 \\
39.28\end{array}$ & $\begin{array}{l}87 \\
81 \\
82 \\
83 \\
83 \\
73\end{array}$ & $\begin{array}{l}1899 \\
1918 \\
1900 \\
1914 \\
1881 \\
1911\end{array}$ & $\begin{array}{l}34.18 \\
37.65 \\
37.31 \\
35.97 \\
35.40 \\
42.65\end{array}$ & $\begin{array}{l}88 \\
82 \\
88 \\
86 \\
84 \\
85\end{array}$ & $\begin{array}{l}1934 \\
1885 \\
1931 \\
1904 \\
1894 \\
1921\end{array}$ & $\begin{array}{l}34.97 \\
37.87 \\
37.36 \\
36.49 \\
35.76 \\
42.92\end{array}$ & $\begin{array}{l}90 \\
83 \\
88 \\
87 \\
85 \\
85\end{array}$ & $\begin{array}{l}1884 \\
1921 \\
1909 \\
1900 \\
1904 \\
1904\end{array}$ & $\begin{array}{l}35.23 \\
38.16 \\
37.38 \\
36.66 \\
36.11 \\
43.27\end{array}$ & $\begin{array}{l}90 \\
83 \\
88 \\
88 \\
86 \\
86\end{array}$ & $\begin{array}{l}1 \\
8 \\
3 \\
3 \\
5 \\
5\end{array}$ & $\begin{array}{l}0 \\
1 \\
2 \\
1 \\
2 \\
3\end{array}$ & $\begin{array}{l}0 \\
0 \\
1 \\
1 \\
1 \\
2\end{array}$ & $\begin{array}{l}0 \\
0 \\
1 \\
1 \\
1 \\
0\end{array}$ \\
\hline $\begin{array}{l}\text { South Carolina } \\
\text { Tennessee.. } \\
\text { Kentucky } \\
\text { West Virgini. } \\
\text { Ohio } \\
\text { Miahigan }\end{array}$ & $\begin{array}{l}48.21 \\
50.30 \\
45.81 \\
43.83 \\
38.44 \\
31.29\end{array}$ & $\begin{array}{l}1925 \\
1930 \\
1930 \\
1930 \\
1934 \\
1930\end{array}$ & $\begin{array}{l}35.82 \\
39.80 \\
27.86 \\
25.43 \\
26.60 \\
22.62\end{array}$ & $\begin{array}{l}74 \\
79 \\
61 \\
58 \\
69 \\
72\end{array}$ & $\begin{array}{l}1933 \\
1925 \\
1894 \\
1895 \\
1930 \\
1934\end{array}$ & $\begin{array}{l}35.95 \\
40.50 \\
34.81 \\
32.82 \\
27.00 \\
25.16\end{array}$ & $\begin{array}{l}75 \\
81 \\
76 \\
75 \\
70 \\
81\end{array}$ & $\begin{array}{l}1931 \\
1904 \\
1904 \\
1904 \\
1895 \\
1925\end{array}$ & $\begin{array}{l}37.17 \\
40.74 \\
35.10 \\
33.33 \\
28.46 \\
25.51\end{array}$ & $\begin{array}{l}77 \\
81 \\
77 \\
76 \\
74 \\
82\end{array}$ & $\begin{array}{l}1911 \\
1894 \\
1901 \\
1894 \\
1894 \\
1910\end{array}$ & $\begin{array}{l}39.80 \\
42.65 \\
35.65 \\
34.52 \\
29.75 \\
25.69\end{array}$ & $\begin{array}{l}82 \\
85 \\
78 \\
79 \\
77 \\
82\end{array}$ & $\begin{array}{l}1930 \\
1895 \\
1889 \\
1887 \\
1901 \\
1889\end{array}$ & $\begin{array}{l}40.15 \\
43.10 \\
33.97 \\
35.33 \\
32.36 \\
26.86\end{array}$ & $\begin{array}{l}83 \\
86 \\
79 \\
81 \\
84 \\
86\end{array}$ & $\begin{array}{l}1904 \\
1931 \\
1934 \\
1885 \\
1900 \\
1895\end{array}$ & $\begin{array}{l}40.98 \\
43.24 \\
37.00 \\
37.23 \\
32.82 \\
26.90\end{array}$ & $\begin{array}{l}85 \\
86 \\
81 \\
85 \\
85 \\
86\end{array}$ & $\begin{array}{l}6 \\
4 \\
7 \\
6 \\
6 \\
1\end{array}$ & $\begin{array}{l}3 \\
1 \\
5 \\
4 \\
4 \\
1\end{array}$ & $\begin{array}{l}2 \\
0 \\
1 \\
2 \\
3 \\
1\end{array}$ & $\begin{array}{l}0 \\
0 \\
1 \\
1 \\
2 \\
0\end{array}$ \\
\hline $\begin{array}{l}\text { Indiana } \\
\text { Illinois.. } \\
\text { Arkansas } \\
\text { Missouri-a } \\
\text { Iowa } \\
\text { Wisconsin }\end{array}$ & $\begin{array}{l}40.17 \\
37.26 \\
48.97 \\
40.17 \\
31.48 \\
31.63\end{array}$ & $\begin{array}{l}1934 \\
1901 \\
1901 \\
1901 \\
1910 \\
1910\end{array}$ & $\begin{array}{l}29.70 \\
25.72 \\
35.27 \\
25.28 \\
19.87 \\
21.41\end{array}$ & $\begin{array}{l}74 \\
69 \\
72 \\
63 \\
63 \\
68\end{array}$ & $\begin{array}{l}1930 \\
1930 \\
1924 \\
1930 \\
1894 \\
1895\end{array}$ & $\begin{array}{l}29.70 \\
27.89 \\
37.03 \\
31.27 \\
21.94 \\
22.45\end{array}$ & $\begin{array}{l}74 \\
75 \\
76 \\
78 \\
70 \\
71\end{array}$ & $\begin{array}{l}1901 \\
1894 \\
1885 \\
1917 \\
1901 \\
1930\end{array}$ & $\begin{array}{l}30.56 \\
28.89 \\
37.55 \\
32.06 \\
24.41 \\
25.03\end{array}$ & $\begin{array}{l}76 \\
78 \\
77 \\
80 \\
78 \\
79\end{array}$ & $\begin{array}{l}1895 \\
1914 \\
1896 \\
1887 \\
1836 \\
1932\end{array}$ & $\begin{array}{l}30.99 \\
28.99 \\
37.72 \\
32.77 \\
24.71 \\
25.37\end{array}$ & $\begin{array}{l}77 \\
78 \\
77 \\
82 \\
78 \\
80\end{array}$ & $\begin{array}{l}1914 \\
1895 \\
1917 \\
1894 \\
1933 \\
1891\end{array}$ & $\begin{array}{l}31.54 \\
31.89 \\
40.72 \\
33.18 \\
24.94 \\
26.12\end{array}$ & $\begin{array}{l}79 \\
86 \\
83 \\
83 \\
79 \\
83\end{array}$ & $\begin{array}{l}1894 \\
1910 \\
1899 \\
1934 \\
1889 \\
1901\end{array}$ & $\begin{array}{l}32.21 \\
32.09 \\
41.49 \\
34.19 \\
24.95 \\
26.34\end{array}$ & $\begin{array}{l}80 \\
86 \\
85 \\
85 \\
79 \\
83\end{array}$ & $\begin{array}{r}7 \\
4 \\
6 \\
6 \\
10 \\
8\end{array}$ & $\begin{array}{l}5 \\
4 \\
4 \\
3 \\
6 \\
4\end{array}$ & $\begin{array}{l}2 \\
2 \\
1 \\
1 \\
2 \\
2\end{array}$ & $\begin{array}{l}0 \\
1 \\
0 \\
1 \\
2 \\
1\end{array}$ \\
\hline $\begin{array}{l}\text { Minnesota } \\
\text { Florida. } \\
\text { Georgia } \\
\text { Alabama } \\
\text { Mississippi... } \\
\text { Louisiana }\end{array}$ & $\begin{array}{l}25.91 \\
52.94 \\
50.48 \\
53.11 \\
53.32 \\
55.64\end{array}$ & $\begin{array}{l}1910 \\
1927 \\
1931 \\
1904 \\
1889 \\
1924\end{array}$ & $\begin{array}{l}14.73 \\
40.71 \\
36.75 \\
39.21 \\
38.31 \\
38.34\end{array}$ & $\begin{array}{l}57 \\
77 \\
73 \\
74 \\
72 \\
6 \theta\end{array}$ & $\begin{array}{l}1889 \\
1917 \\
1904 \\
1931 \\
1924 \\
1889\end{array}$ & $\begin{array}{l}19.08 \\
41.36 \\
37.17 \\
42.78 \\
40.06 \\
40.25\end{array}$ & $\begin{array}{l}74 \\
78 \\
74 \\
81 \\
75 \\
72\end{array}$ & $\begin{array}{l}1923 \\
1931 \\
1893 \\
1889 \\
1904 \\
1917\end{array}$ & $\begin{array}{l}19.81 \\
43.97 \\
40.29 \\
43.30 \\
41.48 \\
40.27\end{array}$ & $\begin{array}{l}76 \\
83 \\
80 \\
82 \\
78 \\
72\end{array}$ & $\begin{array}{l}1934 \\
1883 \\
1927 \\
1914 \\
1896 \\
1899\end{array}$ & $\begin{array}{l}20.30 \\
45.17 \\
40.65 \\
44.90 \\
43.13 \\
42.35\end{array}$ & $\begin{array}{l}78 \\
85 \\
81 \\
85 \\
81 \\
76\end{array}$ & $\begin{array}{l}1929 \\
1921 \\
1921 \\
1925 \\
1899 \\
1904\end{array}$ & $\begin{array}{l}20.56 \\
45.24 \\
40.94 \\
45.20 \\
44.52 \\
43.83\end{array}$ & $\begin{array}{l}79 \\
85 \\
81 \\
85 \\
83 \\
79\end{array}$ & $\begin{array}{l}1933 \\
1895 \\
1925 \\
1910 \\
1887 \\
1896\end{array}$ & $\begin{array}{l}20.97 \\
45.50 \\
11.00 \\
45.20 \\
44.57 \\
46.56\end{array}$ & $\begin{array}{l}81 \\
86 \\
81 \\
85 \\
84 \\
84\end{array}$ & $\begin{array}{l}9 \\
5 \\
7 \\
8 \\
7 \\
8\end{array}$ & $\begin{array}{l}\mathbf{5} \\
2 \\
3 \\
1 \\
3 \\
5\end{array}$ & $\begin{array}{l}2 \\
0 \\
2 \\
1 \\
2 \\
3\end{array}$ & $\begin{array}{l}1 \\
0 \\
0 \\
0 \\
0 \\
1\end{array}$ \\
\hline 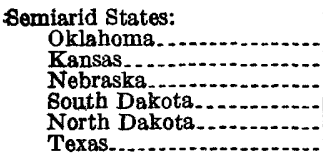 & $\begin{array}{l}32.63 \\
27.48 \\
23.50 \\
20.77 \\
17.70 \\
30.84\end{array}$ & $\begin{array}{l}1910 \\
1917 \\
1894 \\
1934 \\
1934 \\
1917\end{array}$ & $\begin{array}{l}18.92 \\
19.60 \\
13.30 \\
13.18 \\
9.49 \\
16.21\end{array}$ & $\begin{array}{l}58 \\
71 \\
57 \\
63 \\
54 \\
53\end{array}$ & $\begin{array}{l}1891 \\
1910 \\
1934 \\
1931 \\
1917 \\
1893\end{array}$ & $\begin{array}{l}22.31 \\
19.67 \\
14.40 \\
14.66 \\
10.92 \\
20.47\end{array}$ & $\begin{array}{l}68 \\
72 \\
61 \\
71 \\
62 \\
67\end{array}$ & $\begin{array}{l}1917 \\
1934 \\
1893 \\
1894 \\
1889 \\
1910\end{array}$ & $\begin{array}{l}22.39 \\
19.92 \\
16.80 \\
15.30 \\
11.30 \\
21.46\end{array}$ & $\begin{array}{l}69 \\
72 \\
71 \\
74 \\
64 \\
70\end{array}$ & $\begin{array}{l}1901 \\
1893 \\
1910 \\
1933 \\
1910 \\
1901\end{array}$ & $\begin{array}{l}22.78 \\
20.25 \\
17.03 \\
15.31 \\
12.19 \\
22.23\end{array}$ & $\begin{array}{l}70 \\
74 \\
72 \\
74 \\
69 \\
72\end{array}$ & $\begin{array}{l}1888 \\
1894 \\
1890 \\
1910 \\
1933 \\
1909\end{array}$ & $\begin{array}{l}23.40 \\
20.72 \\
17.18 \\
15.49 \\
13.34 \\
23.45\end{array}$ & $\begin{array}{l}72 \\
75 \\
73 \\
75 \\
75 \\
76\end{array}$ & $\begin{array}{l}1896 \\
1890 \\
1895 \\
1925 \\
1929 \\
1924\end{array}$ & $\begin{array}{l}23.78 \\
21.16 \\
18.75 \\
15.90 \\
14.32 \\
23.50\end{array}$ & $\begin{array}{l}73 \\
77 \\
80 \\
77 \\
81 \\
76\end{array}$ & $\begin{array}{r}14 \\
12 \\
9 \\
12 \\
10 \\
11\end{array}$ & $\begin{array}{r}10 \\
7 \\
6 \\
9 \\
5 \\
7\end{array}$ & $\begin{array}{l}6 \\
5 \\
5 \\
5 \\
5 \\
4\end{array}$ & $\begin{array}{l}1 \\
0 \\
2 \\
1 \\
4 \\
3\end{array}$ \\
\hline $\begin{array}{l}\text { Arid States: } \\
\text { New Mexico... } \\
\text { Colorado } \\
\text { Wyoming } \\
\text { Montana } \\
\text { Idaho } \\
\text { Nevada }\end{array}$ & $\begin{array}{r}14.49 \\
16.79 \\
14.05 \\
15.21 \\
17.17 \\
9.01\end{array}$ & $\begin{array}{l}1910 \\
1934 \\
1886 \\
1889 \\
1888 \\
1928\end{array}$ & $\begin{array}{r}9.46 \\
10.93 \\
7.16 \\
9.24 \\
10.08 \\
4.87\end{array}$ & $\begin{array}{l}65 \\
65 \\
51 \\
61 \\
59 \\
54\end{array}$ & $\begin{array}{l}1917 \\
1890 \\
1887 \\
1931 \\
1889 \\
\mathbf{1 8 8 7}\end{array}$ & $\begin{array}{r}9.49 \\
11.97 \\
8.80 \\
10.09 \\
12.05 \\
5.18\end{array}$ & $\begin{array}{l}65 \\
71 \\
62 \\
66 \\
70 \\
57\end{array}$ & $\begin{array}{l}1892 \\
1888 \\
1902 \\
1890 \\
1924 \\
1924\end{array}$ & $\begin{array}{r}9.51 \\
12.00 \\
9.81 \\
10.78 \\
12.46 \\
5.49\end{array}$ & $\begin{array}{l}66 \\
71 \\
70 \\
71 \\
73 \\
61\end{array}$ & $\begin{array}{l}1934 \\
1893 \\
1919 \\
1904 \\
1929 \\
1910\end{array}$ & $\begin{array}{r}9.96 \\
12.89 \\
10.46 \\
11.04 \\
13.06 \\
5.53\end{array}$ & $\begin{array}{l}69 \\
77 \\
74 \\
73 \\
76 \\
61\end{array}$ & $\begin{array}{l}1902 \\
1889 \\
1893 \\
1919 \\
1928 \\
1888\end{array}$ & $\begin{array}{r}9.97 \\
13.73 \\
10.67 \\
11.14 \\
13.60 \\
5.76\end{array}$ & $\begin{array}{l}69 \\
82 \\
76 \\
73 \\
79 \\
64\end{array}$ & $\begin{array}{l}1894 \\
1924 \\
1889 \\
1934 \\
1895 \\
1929\end{array}$ & $\begin{array}{r}10.47 \\
13.75 \\
10.81 \\
11.25 \\
13.63 \\
5.83\end{array}$ & $\begin{array}{l}72 \\
82 \\
77 \\
74 \\
79 \\
65\end{array}$ & $\begin{array}{r}12 \\
12 \\
13 \\
10 \\
9 \\
16\end{array}$ & $\begin{array}{r}12 \\
4 \\
8 \\
7 \\
6 \\
16\end{array}$ & $\begin{array}{r}9 \\
3 \\
4 \\
6 \\
6 \\
3 \\
11\end{array}$ & $\begin{array}{l}5 \\
1 \\
3 \\
2 \\
2 \\
7\end{array}$ \\
\hline $\begin{array}{l}\text { Utah } \\
\text { Arizona } \\
\text { California } \\
\text { Eastern Oregon } \\
\text { Western Oregon } \\
\text { Eastern Washington. } \\
\text { Western Washington.... } \\
\end{array}$ & $\begin{array}{l}12.67 \\
13.10 \\
23.53 \\
13.81 \\
54.22 \\
16.89 \\
56.98\end{array}$ & $\begin{array}{l}1887 \\
1885 \\
1898 \\
1908 \\
1980 \\
1929 \\
1922\end{array}$ & $\begin{array}{r}6.55 \\
7.12 \\
10.35 \\
9.32 \\
37.11 \\
10.19 \\
43.02\end{array}$ & $\begin{array}{l}52 \\
54 \\
44 \\
68 \\
68 \\
60 \\
76\end{array}$ & $\begin{array}{l}1883 \\
1900 \\
1923 \\
1898 \\
1929 \\
1890 \\
1890\end{array}$ & $\begin{array}{r}7.72 \\
8.17 \\
14.13 \\
9.72 \\
\mathbf{3 8 . 6 6} \\
12.00 \\
\mathbf{4 3 . 1 7}\end{array}$ & $\begin{array}{l}61 \\
62 \\
60 \\
70 \\
71 \\
71 \\
76\end{array}$ & $\begin{array}{l}1900 \\
1903 \\
1887 \\
1924 \\
1918 \\
1898 \\
1929\end{array}$ & $\begin{array}{r}8.38 \\
8.43 \\
14.63 \\
10.42 \\
43.28 \\
12.02 \\
44.01\end{array}$ & $\begin{array}{l}66 \\
64 \\
62 \\
76 \\
80 \\
71 \\
77\end{array}$ & $\begin{array}{l}1890 \\
1924 \\
1895 \\
1918 \\
1905 \\
1930 \\
1905\end{array}$ & $\begin{array}{r}9.00 \\
8.68 \\
14.85 \\
10.53 \\
44.11 \\
12.12 \\
46.18\end{array}$ & $\begin{array}{l}71 \\
66 \\
63 \\
76 \\
81 \\
72 \\
81\end{array}$ & $\begin{array}{l}1902 \\
1899 \\
1929 \\
1905 \\
1892 \\
1895 \\
1011\end{array}$ & $\begin{array}{r}9.17 \\
8.70 \\
15.00 \\
10.80 \\
44.25 \\
12.92 \\
46.81\end{array}$ & $\begin{array}{l}72 \\
66 \\
64 \\
78 \\
82 \\
77 \\
82\end{array}$ & $\begin{array}{l}1934 \\
1904 \\
1932 \\
1928 \\
1923 \\
1922 \\
1923\end{array}$ & $\begin{array}{r}9.49 \\
9.24 \\
1.60 \\
11.21 \\
44.89 \\
13.37 \\
\mathbf{4 7 . 2 5}\end{array}$ & $\begin{array}{l}75 \\
71 \\
66 \\
81 \\
83 \\
79 \\
83\end{array}$ & $\begin{array}{r}18 \\
15 \\
19 \\
10 \\
9 \\
11 \\
9\end{array}$ & $\begin{array}{r}11 \\
13 \\
15 \\
5 \\
3 \\
6 \\
3\end{array}$ & $\begin{array}{r}6 \\
11 \\
10 \\
2 \\
2 \\
4 \\
0\end{array}$ & $\begin{array}{l}3 \\
5 \\
7 \\
2 \\
1 \\
1 \\
0\end{array}$ \\
\hline
\end{tabular}

- Means for Oregon and Washington are for period of record, 1890-1934.

142748-36. (Face p. 66-No. 2.) 
In the 31 humid States the time interval between specially noticeable droughts has ranged from 3 to 7 years. During the 7 most severe drought years the area affected ranged from 30 to 63 percent of the total. Deficiencies in precipitation were as high as 28 percent. In extent of the area affected and deficiency of precipitation, 1930 was the most severe drought year of record. The next 2 were 1894 and 1901.

In 5 semiarid States (North Dakota, South Dakota, Nebraska, Kansas, and Oklahoma) the time interval between droughts has
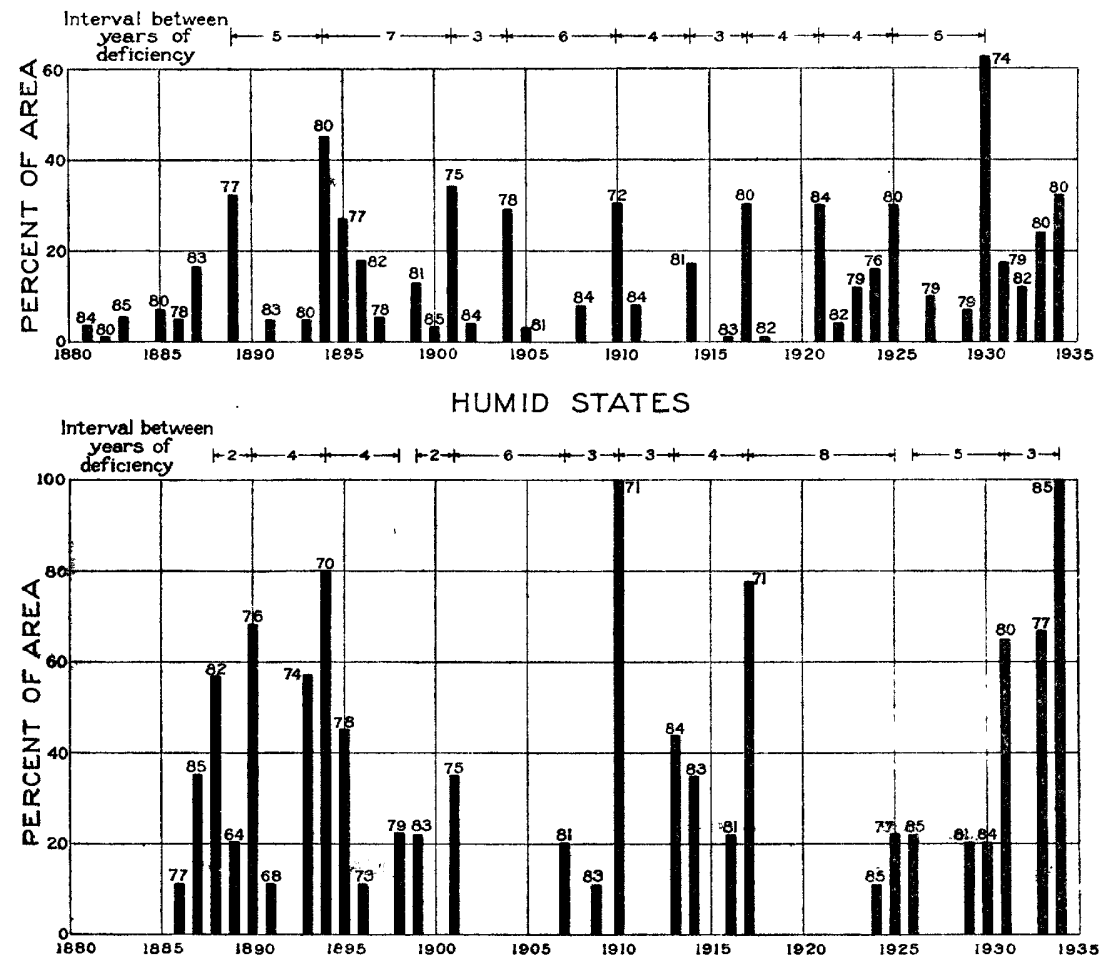

5 SEMIARID STATES

(North Dakota, South Dakota, Nebraska, Kansas, and Oklahoma)

ThavRe 19.-Percentage of area having deficiencies in precipitation of 15 percent or more, 1881-1934, for 31 humid states and 5 semiarid States. Small figures on graph indicate precipitation in percent of mean in the area of deflciency.

ranged from 2 to 8 years. During each of the 7 most severe drought years over 64 percent of their area was affected, and there were 2 years, 1910 and 1934, when the deficiency in precipitation over the whole area was 29 and 35 percent, respectively. In extent of the area affected and deficiency of precipitation, therefore, 1934 was the most severe drought year of record in these States. The next 2 were 1894 and 1910. In general, drought damages in the semiarid States have been more severe than in the humid States. 
Although definite data as to damage are not available, 1930 probably ranks highest in humid States, and 1934 in semiarid States.

In 1906 the United States Weather Bureau reported ${ }^{15}$ that

The greatest drought this country has experienced in the last 100 years, both as to intensity and extent of territory covered, culminated in the middle Mississippi and Missouri Valleys in 1894 and in the Lake region and Atlantic coast districts in 1895 . ***

The next serious drought was in 1881. It affected practically the whole of the country east of the Mississippi and lasted from July to September. * * * The most striking characteristic of this drought was its duration and attendant high temperatures. Vegetation and staple crops were seriously damaged, and in the latter stages of the drought there was a scarcity of water for domestic use and for manufacturing purposes. In many places scores of shops and factories were obliged to shut down for lack of water.

Later Weather Bureau reports briefly referred to marked drought conditions during 1910.

The drought of 1881 was evidently of short duration and slight extent. There were but few localities where records indicated precipitation below the mean for more than 2 consecutive months, and these low months, were either preceded or followed by months of excessive precipitation, so that for most States the average precipitation for the year was almost equal to or above the mean. In fact, out of the 36 nonarid States, precipitation for the year was below the mean in only 11. In none of these States was the precipitation below 84 percent of the mean. In the Ohio Valley, July and August were extremely deficient in precipitation, but the Lake region had normal rainfall. Western New York, Pennsylvania, Maryland, Delaware, and Virginia as a whole had only 1 summer month of major deficiency in precipitation. These deficient months, accompanied by high temperatures that severely affected vegetation, probably led to the classification of the drought of 1881 , although short in duration; with the major drought period of 1894-95.

An indication of drought conditions since 1769 in southern California is given in the following summary ${ }^{16}$ of precipitation trends, taken from statements in letters and reports of the mission padres:

1. There has been no material change in the mean climatic conditions of southern California in the past 162 years.

2. There have been earlier fluctuations from average rainfall conditions, however, both excesses and deficiencies, of greater magnitude than any. which wave occurred in the past 40 years.

3. The 28 -year period of rainfall deficiency which ended in 1810 was about as severe as has been the present one to date, and much more protracted.

4. The period of rainfall surplus from 1810 to 1821 was more intense than anvthing in the past 40 years. It seems to have been about as intense as was that between 1883 and 1893 .

${ }^{15}$ Henry, A. J., Climatology of the United States; U. S. Weather Bur., Bull. Q, p. 51, 1906.

${ }^{16}$ Lynch, H. B., Rainfall and stream run-off in southern California since 1769, Metropolitan Water District of southern California, August 1931. 
5. The period of rainfall deficiency which lasted from about 1822 to 1832 was more severe than has been any occurring since.

6. The period of rainfall deficiency which commenced in 1842 and lasted until 1883 was much longer than any other of which we have record. It was not so acute, however, as some others, both earlier and later. It was broken by a period of normal rainfall but was without any period of excess rainfall to balance the deficiency.

7. In comparison with several periods of rainfall shortage which have occurred in past years, the present rainfall deficiency to date cannot be considered a major shortage.

8. For all practical purposes the useful water yield of the areas under consideration closely approximates the run-off from the principal streams of these areas, except in times of heavy floods.

9. The run-off from southern California streams has in general shown fluctuations from the normal similar in character to those of the rainfall, but larger in relative percentage.

10. By reason of these fluctuations, the useful water yield has at various times been reduced from the average by considerably more than one-half for a period of 10 years, and by 30 percent for a period of 28 years.

\section{DROUGHT AND LOW-WATER STREAM FLOW}

Figure 20 shows the location of 47 river-measurement stations that have been selected to indicate the relation of droughts to stream flow in various sections of the country. No stations have been included for streams where the regimen appears to have been changed by diversion or storage works. Minimum discharges and other data for these selected stations are given in table 17 .

The minimum flows for the various months as determined from the records available indicate that similar low flows may be expected in the future and their combination may be assumed to represent a possible composite (built up) low-water year. A year having even lower flow must also be considered a possibility. For example, such a composite year for the Potomac River at Point of Rocks, Md., indicates that a minimum annual flow of 2,160 second-feet or less is possible and even probable. For the period of record the consecutive 12 months of minimum flow started with April 1930, and during these 12 months the mean flow was 2,450 second-feet, or only 290 second-feet greater than in the composite minimum year. With the exception of February and April, the minimum discharge for all months occurred in the 12-month period beginning May 1930. The minimum for February occurred in 1934; for April, in 1915.

The minimum monthly discharge of many streams for most of the months occurred during the drought periods of 1930-34. The probability of other sequences of so many months of ninimum flow is remote, and therefore for the drought areas of 1930-34 these figures will probably serve for some time as a basis for estimating low-water flows. Records of daily and monthly flow in connection with 
deficiency tables as given for the Potomac River on pages 29-30 are necessary to determine the frequency of the effects of drought on low-water flows.

\section{CARRY-OVER EFFECT AS RELATED TO DROUGHT}

The carry-over effect of water supplies as related to drought periods may pertain to vegetation, to surface water, to soil moisture, and to ground water. On account of the counterbalancing influences that follow drought periods the subject is not readily understood, and a study of available information indicates that some phases of the carryover effects have probably been overemphasized in hydraulic studies.

In the humid and semiarid States vegetation depends primarily upon the accumulated soil moisture at the time of planting and a

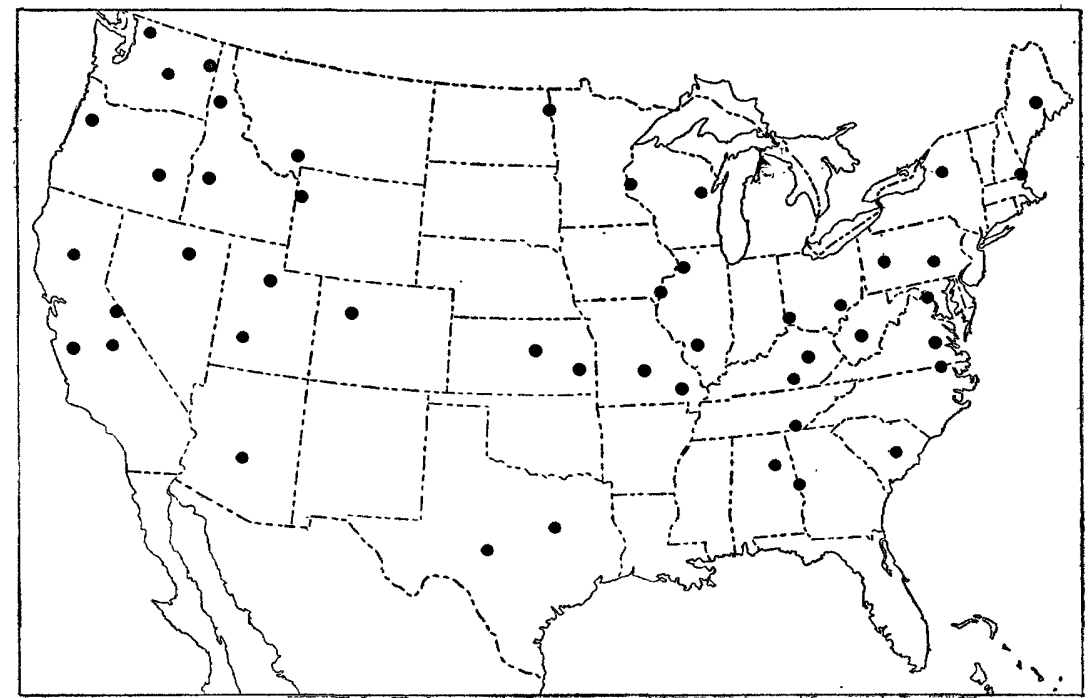

FIGURE 20.-Location of river-measurement stations used to show the relation of drought and stream flow.

favorably distributed precipitation during the growing season. Therefore, the principal carry-over effect on vegetation is in connection with soil moisture. In the arid regions successful agriculture depends in a large measure on stored water. Therefore, if adequate storage facilities are available, shortages of water due to drought may in a large measure be overcome from accumulations in storage of excesses in supplies during previous years.

It has been noted that the vegetable growth in years following droughts is especially vigorous. This may perhaps be accounted for by the fact that during the excessive drought years the land is dormant on account of lack of sufficient moisture to sustain vegetable growth. There is nothing to indicate any large detrimental carry-over effect on vegetation due to drought during the period 1930-34. 
During drought periods surface waters stored in lakes, ponds, and reservoirs are usually heavily drawn upon and may be depleted entirely. The replenishment of these stored supplies in years following drought may draw so heavily on the precipitation as to cause noticeable shortages for various uses. Replenishment of groundwater storage may result in the same effect.

\section{ALLEVIATION OF DROUGHT DAMAGE}

Droughts are natural phenomena brought about by deficient and poorly distributed precipitation, high temperatures, and hot winds, which in turn depend upon other natural phenomena over which man has no control. There is nothing, therefore, that man can do to modify their occurrence. However, the economic losses resulting from shortages of water caused by droughts relate to activities that man can control, and it is possible for man to do much toward the alleviation of such losses by the conservation of available water supplies by storage, by efficiency in all uses of water, and by the adjustment of activities that depend upon water to available supplies and to variations in supplies.

In order to exercise either of these three controls, it is necessary to have complete information in regard to all available supplies, their fluctuations, and the possibilities for their conservation. This information should include climatic records, especially of precipitation; records of stream flow from which both the total flow and the distribution of flow that may be expected can be estimated; and records of fluctuations of the ground-water table, with other information relative to ground-water supplies. Topographic maps of watercourses, indicating reservoir sites and possibilities for diversion, will also be required.

Drought damages depend in a large measure on the climate of the area affected-that is, whether it is humid, semiarid, or arid-and on the type of activities in the area. Therefore, a full knowledge of the water requirements for agriculture and other activities in each area is also important in combating drought damages.

Although far from adequate, records of precipitation, temperature, stream flow, and other natural phenomena relating to water supplies are now of sufficient length to give an indication as to how far activities depending upon water can be extended without serious loss on account of deficient supplies. The extent to which economic losses due to droughts are eliminated will depend on the continuation and extension of these records and their use both in planning and in operation.

The humid areas in general have adequate precipitation to meet the needs of vegetation, both natural and agricultural, to supply adequate surface and ground waters to meet present demands for various other 
needs; and also in most sections for additional demands if expansion is wisely planned. In any year there may be small areas that have shortages of water, and at intervals varying from 15 to 20 years there may be major shortages. In general, however, if due consideration is given to the character and extent of development, there should be no serious inconvenience due to water shortages in the humid areas, except at long intervals. If agriculture and other activities are properly planned and the facilities for utilizing available supplies are provided, damage due to these shortages can be minimized.

In the arid sections special caution should be exercised in the expansion of activities that will increase water-supply demands, until more information is available in regard to the amount of water that can reasonably be depended upon. Although there have been shortages of supply in many localities during drought years, the indications are that these shortages can, in the main, be overcome if all available sources are developed and if facilities are provided for their economic use. If, however, the present climatic trends in the arid sections continue, the development of additional water needs in many localities may result in serious loss.

The most pressing water-supply problems of the country are in the semiarid areas, which since their early settlement have had more or less trouble on account of deficient water supplies, especially as related to agriculture, the principal activity in these areas. The indications are that much readjustment must be made in these areas before they can be placed upon a secure basis in respect to water demands, and this will require much careful study not only of the available supplies that can be expected but of the types of agriculture and other activities that can be successfully carried on as limited by these supplies.

At the present time much water is made unavailable for use, especially in the vicinity of centers of population, by pollution from sewage and other wastes, and the conditions may eventually become so acute that large expenditures for elimination of pollution will be justified. Governmental agencies, Federal, State, and local, should give this question careful study with the idea of setting up sufficient regulatory measures to avoid disaster from pollution in times of drought. No section of the country is free from this danger.

The people who live on the land may be divided into three groupsfirst, the agricultural industrialist, who is primarily interested in money crops and does not attempt to supply his own food needs; second, the farmer who raises both food for his subsistence needs and money crops and who is thus self-contained on the farm; third, the subsistence agriculturist, who raises only food crops and depends on outside work for his money. 
As a large percentage of the people who live on the land fall in the last two classes, the bulk of the food supply that enters into the commerce of the country is produced by a comparatively small percentage of the rural population. Drought effects are more serious to the group of agricultural industrialists than to the subsistence groups, as it is an exceptional drought in which there is not sufficient production of crops for subsistence, although supplies may at times be meager. In fact, during all drought years suffering has been largely confined to areas which have been devoted primarily to commercial agriculture and in which no special attention is given to subsistence needs. One of the outstanding results of the drought of 1930 was the large extension of subsistence agriculture in areas that had heretofore depended wholly upon money crops.

The Arkansas "live-at-home program" 17 developed as a result of the drought of 1930 indicates that a real solution to the problem of the alleviation of drought damages in rural sections is to eliminate the marginal producer and to insure that each farm unit raise suffcient food for its own needs. Under this program Arkansas officials are working to lift the one-crop curse and persuade farmers to plant food as well as money crops, so that they may be at least partly self-sustaining in time of drought. The principles of this constructive program are as follows:

To raise enough grain and hay to feed all livestock.

To produce enough meat to supply the family's needs.

To keep enough milk cows to supply the family with an abundance of milk and butter.

To provide health insurance in the form of a year-round garden, and to preserve any surplus of home-raised vegetables.

To maintain a flock of at least 30 laying hens.

To give increased care to home orchards, and in areas where no fruit is grown at present to plant enough fruit trees to supply the family's needs.

To rebuild soil fertility by planting at least half the present corn and cotton acreage to legumes and pasture crops.

To reduce tilled acreage and apply the surplus labor to terracing and drainage.

To install at least one home convenience and to beautify each homestead by painting all buildings, improving farm lawns, and planting flowering trees and shrubs.

One of the obstacles in the alleviation of drought damages is conservatism and the difficulty in changing established practices. This applies especially to the arid West and is illustrated by conditions outlined in the annual report dated March 4, 1935 (unpublished), of the committee of nine to the water users of district 36 , Idaho, which comprises the Snake River drainage basin, as follows:

During a long series of years up to 1923 Snake River had an abundant run-off during 4 out of every 5 years. The streams remained at high stage until well

17 How to live at home: Arkansas Univ. Coll. Agr. Extension Circ. 255, 1931.

$142748-36-6$ 
into July and discharged in ordinary years $5,000,000$ acre-feet annually past Milner to the ocean. During the past decade, however, the stream flow has greatly decreased. During the past 6 years, for example, the amount of water discharged past American Falls was only. 50 percent of the amount during the 6 years from 1909 to 1914 . The continuation of the present low discharge for so long a period, taken in conjunction with tree-ring and geologic studies, indicates that it is not unlikely that the period from the early settlement of the valley up to 1923 was one of overabundant water supply and that the present situation more nearly represents the normal condition.

If this proves to be the case, the water users on Snake River will be forced by necessity to eliminate certain pioneer habits and practices in the use of water that they acquired during the years of abundance and learn to adopt all available methods of conservation or else abandon part of the acreage now irrigated.

As a practical matter, however, in view of the established rights, viewpoint, and habits of the various water users, it is difficult to propose any plan to improve the present water supply that does not meet with the opposition of some section which feels that its rights and needs, either real or imaginary, are being infringed upon. As one studies the situation and comes to appreciate the difficulties involved in accomplishing the full conservation and efficient use of the waters of Snake River he feels a certain sympathy with that Persian poet who, 500 years ago, was moved to exclaim:

\section{"Ah! would that I could grasp \\ This sorry scheme of things entire \\ And mold a world anew \\ Nearer to my heart's desire!"}

In all countries and at all times water has been the limiting factor in social and other development. We have now reached a time in the development of this country when much more careful consideration must be given to water supply than has been given in the past, or serious consequences will result. The disastrous effects of recent droughts in the arid and semiarid States have in a large measure been due to failure to give adequate study to the relation of water supply to development. With the growth of the country detrimental effects of droughts increase, and they will continue to increase unless a proper relation between water supplies and requirements is established and maintained. It is not safe to assume that droughts of greater severity than those which have been recorded will not occur, and even if they are not more severe, as measured by deficiency in water and length, their economic effects will be greater as utilization of and demands for water are increased. The maximum development and successful use of all natural resources can be accomplished only on the basis of full and reliable information as to water supplies, with special emphasis on drought periods, and, in order that this information may be available, it is essential that adequate provision be made for the collection of systematic records of the Nation's water resources on a continuing basis. 


\section{PRECIPITATION DIAGRAMS}
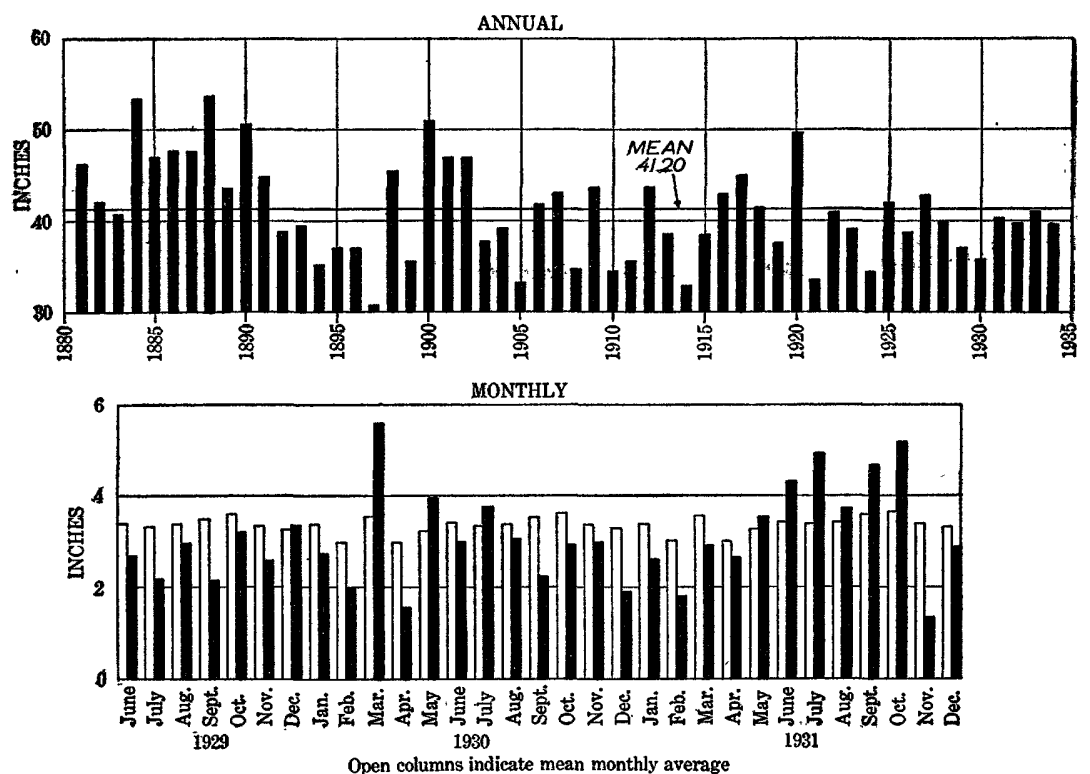

Figure 21.-Annual precipitation in Maine, 1881-1934, and monthly precipitation, June 1929 to December 1931.
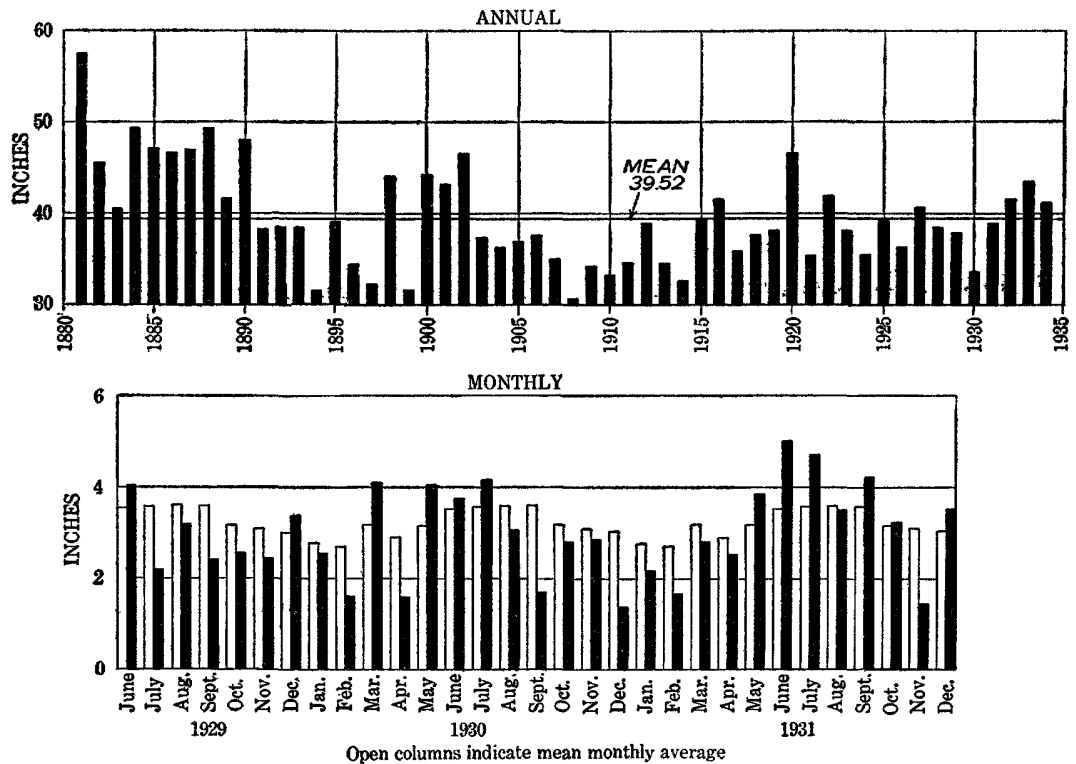

FIGURE 22.-Annual precipitation in New Hampshire, 1881-1934, and monthly precipitation, June 1929 to December 1931 . 

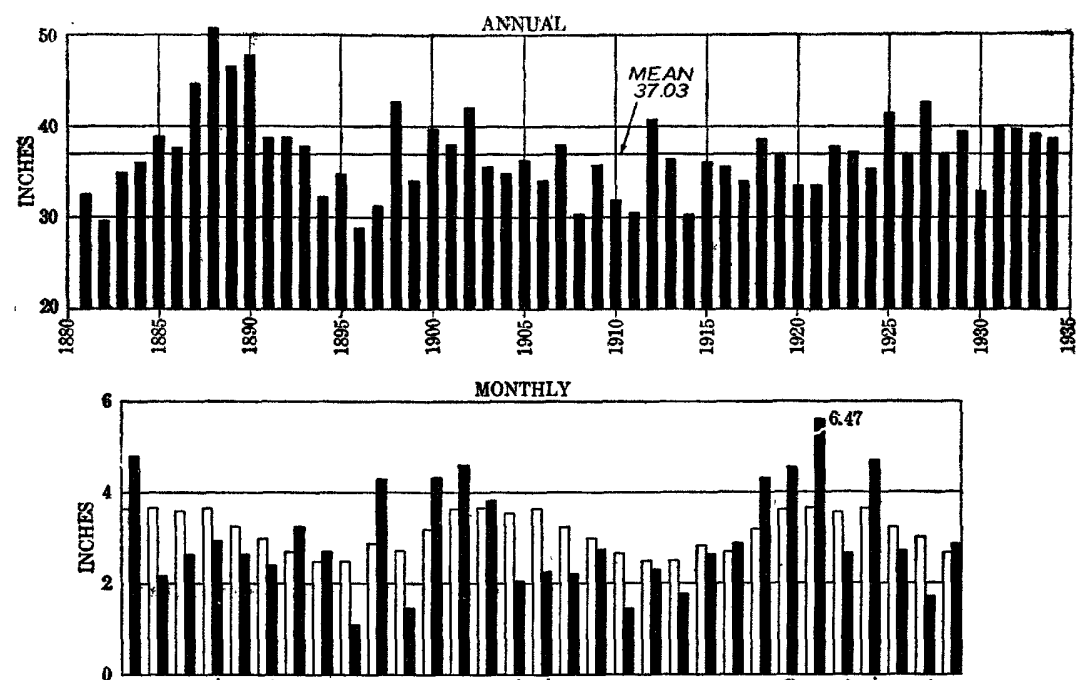

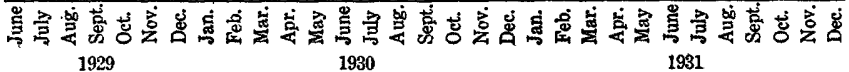

Open columns indicate mean monthly average

FlGURE 23.-Annual precipitation in Vermont, 1881-1934, and monthly precipitation, June 1929 to December 1931.
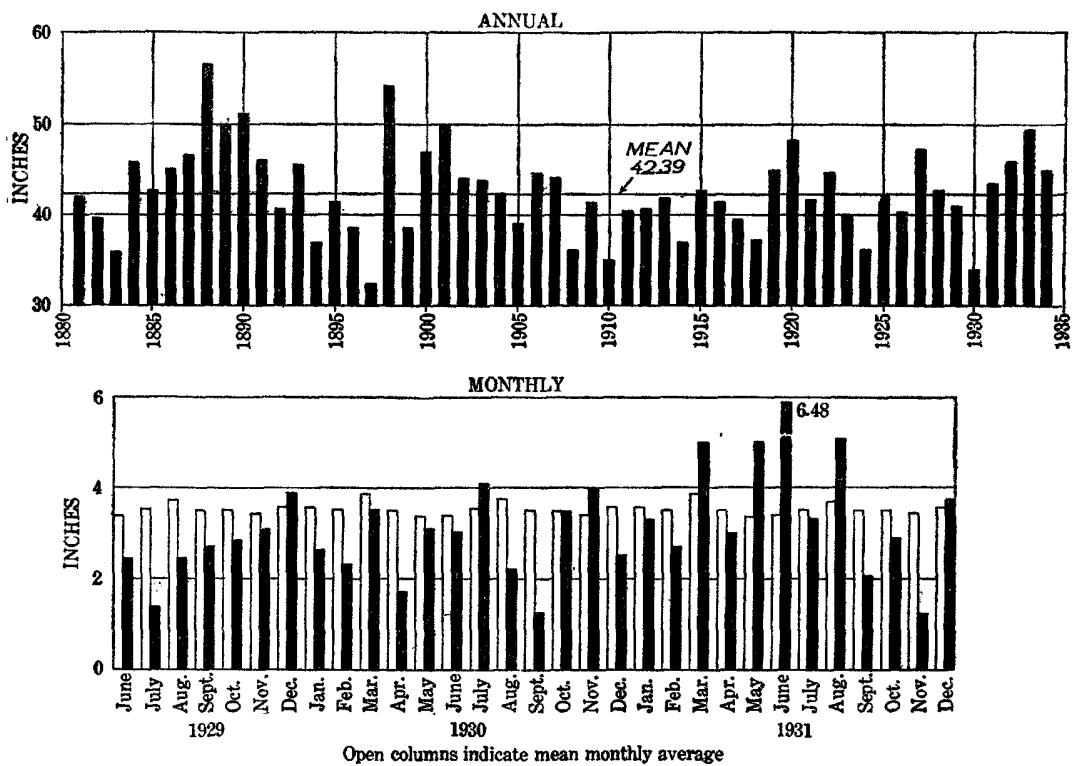

Fiaune 24.-Annual precipitation in Massachusetts, 1881-1934, and monthly precipitation, June 1929 to December 1931. 

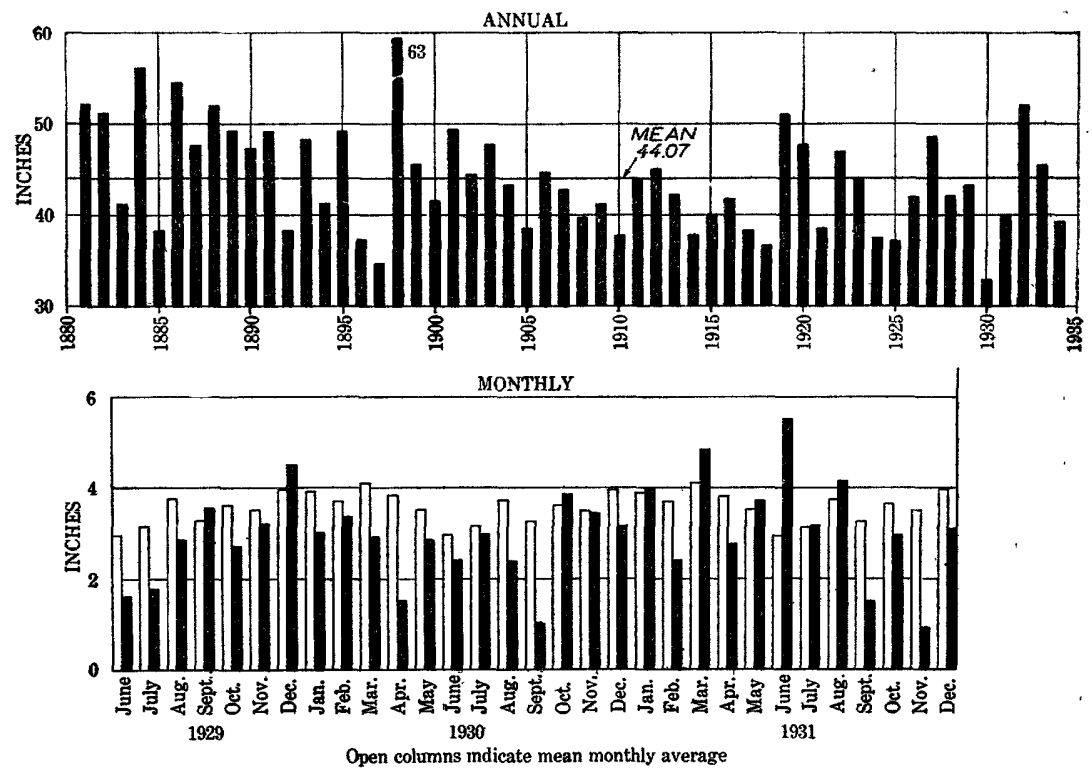

FraURe 25.-Annual precipitation in Rhode Island, 1881-1934, and monthly precipitation, June 1929 to December 1931.
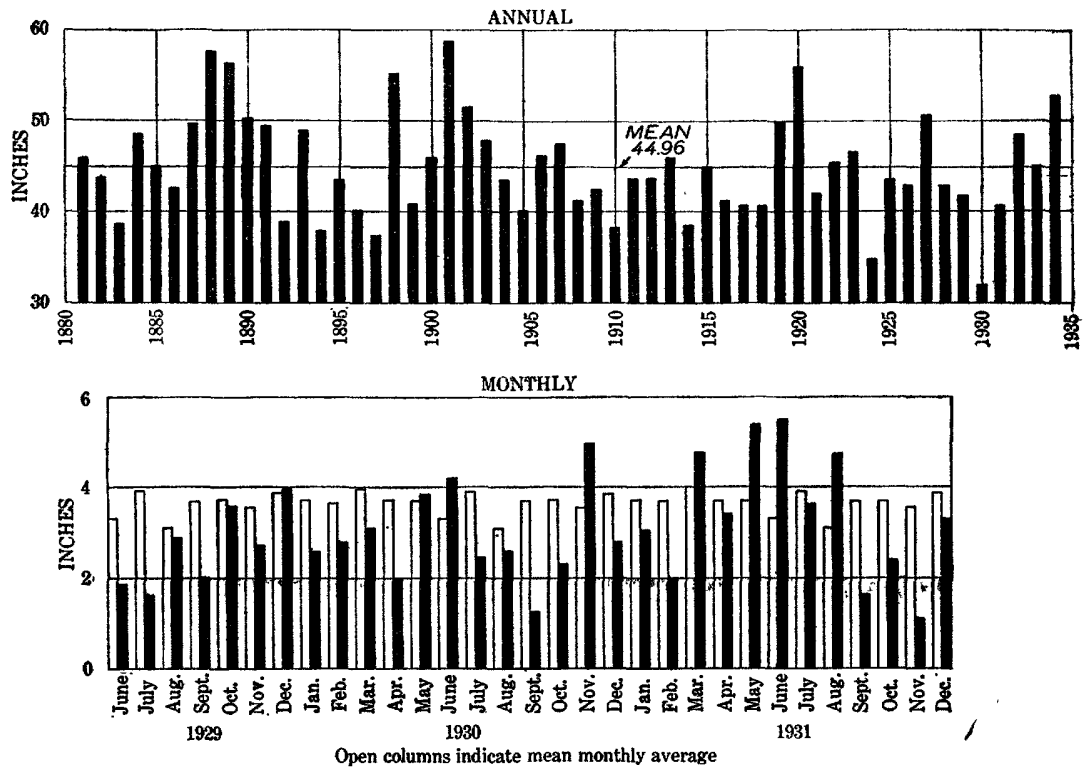

Fiavne 26.-Annual precipitation in Connecticut, 1881-1934, and monthly precipitation, June 1929 to December 1931. 


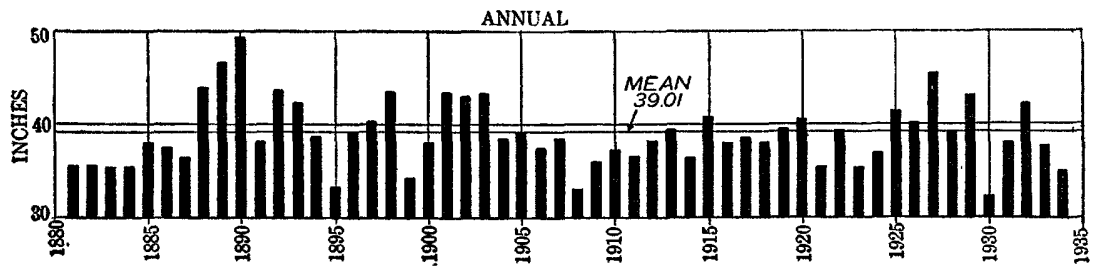

MONTHLY

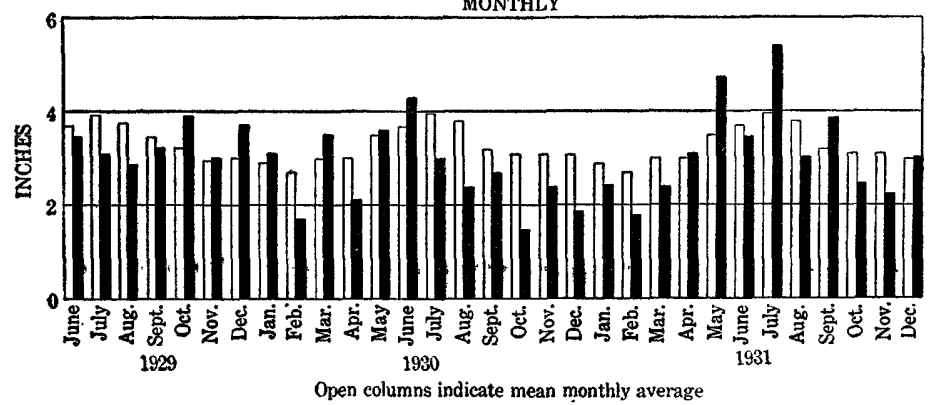

Figore 27.-Annual precipitation in New York, 1881-1934, and monthly precipitation, June 1929 to Decomber 1931 .

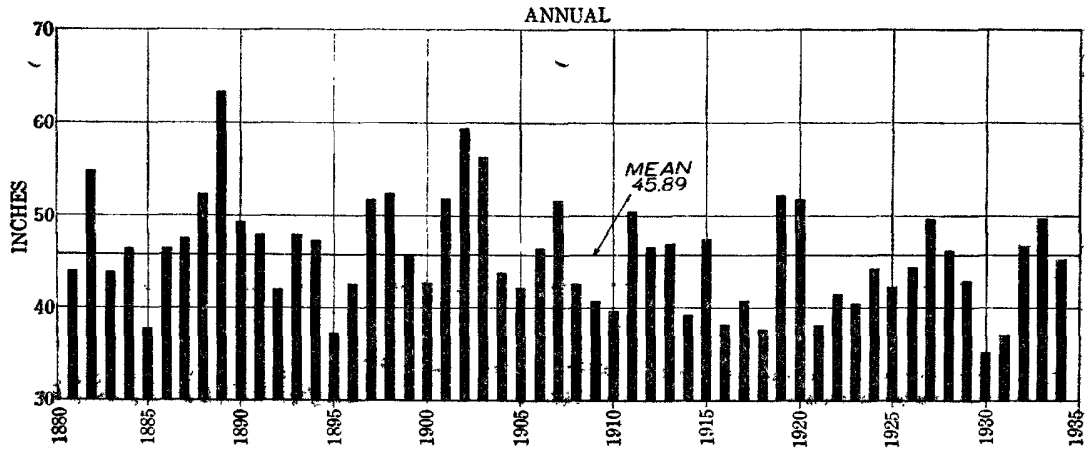

MONTHLY

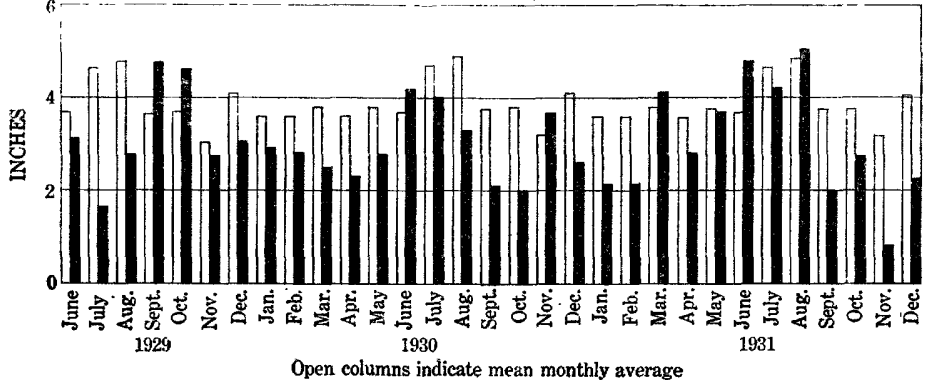

Fioure 28.-Annual precipitation in New Jersey, 1881-1934, and monthly precipitation, June 1929 to December 1931. 

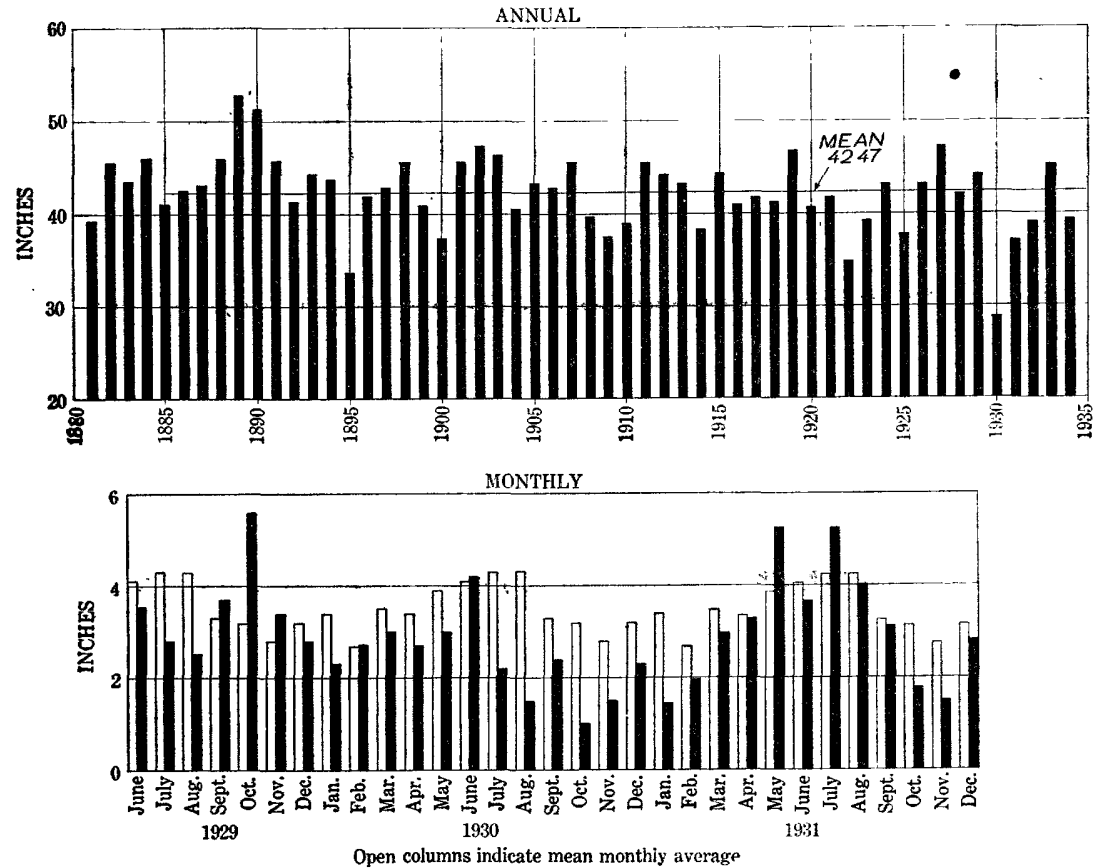

Fugure 29.-Annual precipitation in Pennsylvania, 1881-1934, and monthly precipitation, June 1929 to December 1931.
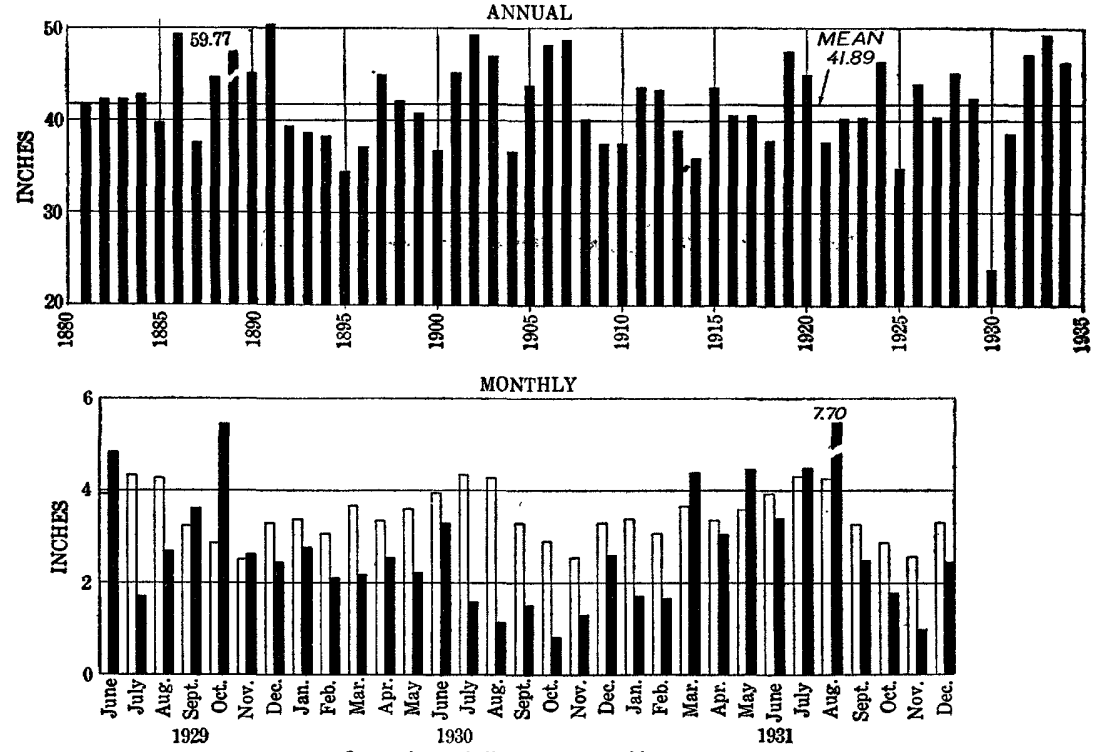

Open columns indicate mean monthly average

FIGorx 30.-Annual precipitation in Maryland-Delaware, 1881-1934, and monthly precipitation, Juno 1929 to December 1931. 

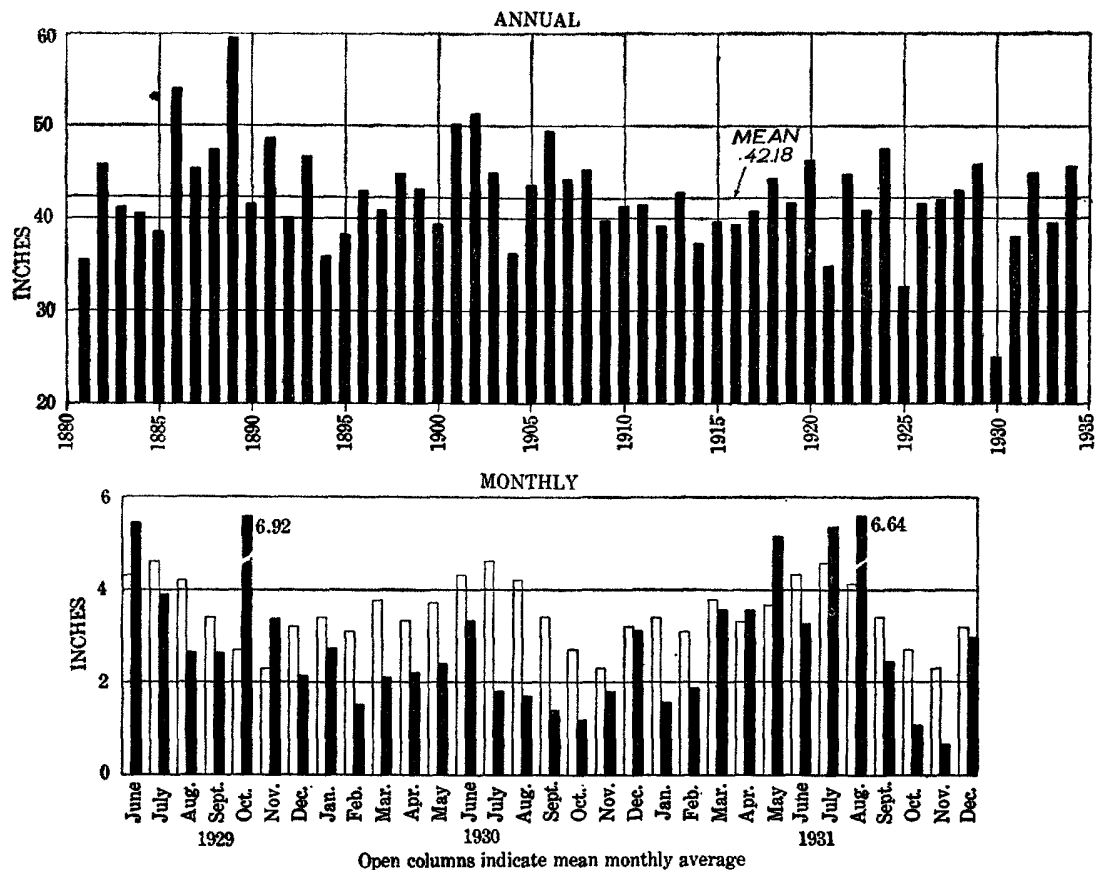

Frauks 31.-Annual precipitation in Virginia, 1881-1934, and monthly precipitation, June. 1929 to December 1931.
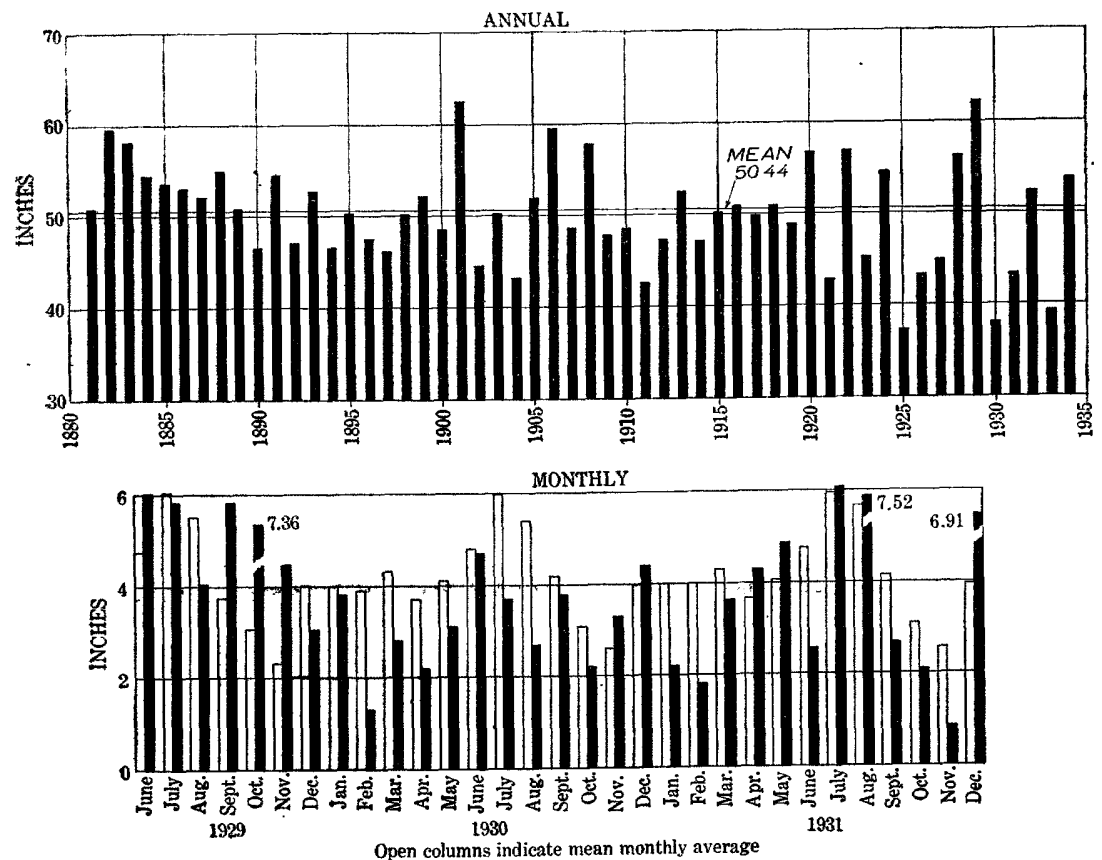

Fravan 32.-Annual precipitation in North Carolina, 1881-1934, and monthly precipitation, June 1029 to December 1931. 

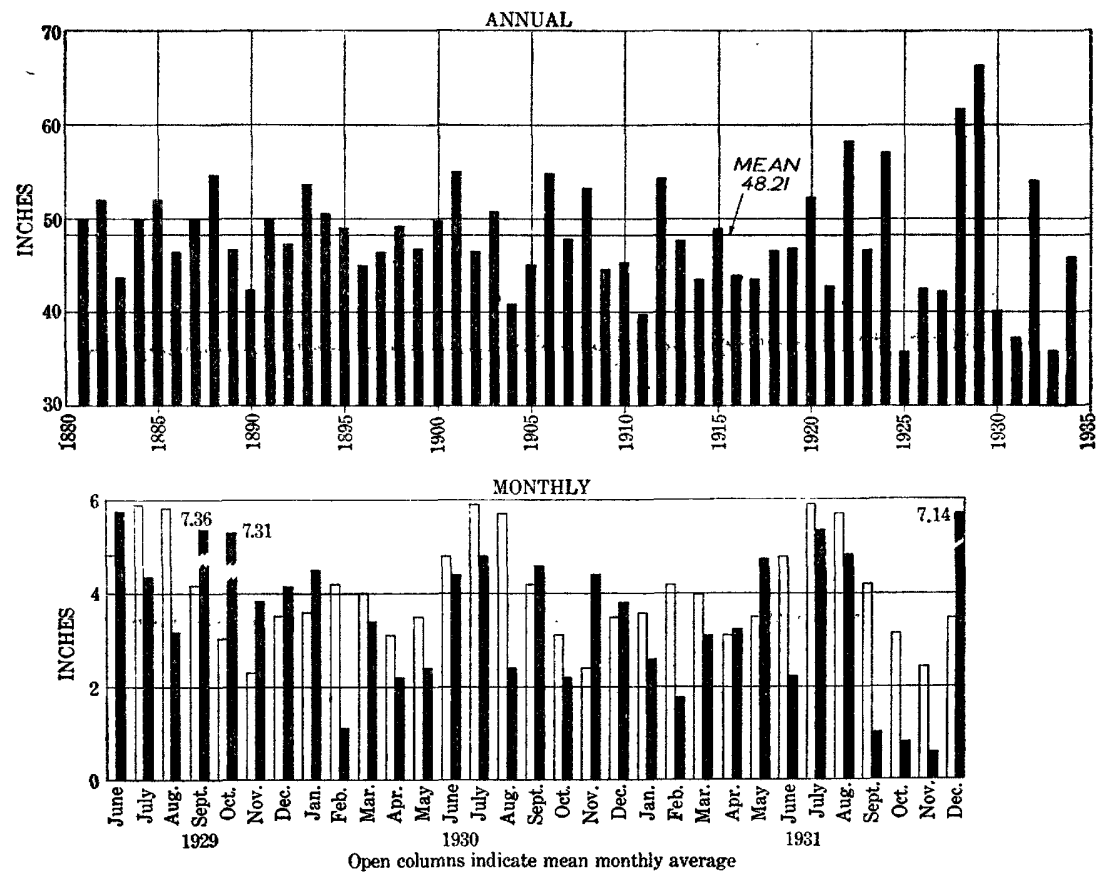

Frounz 33.-Annual precipitation in South Carolina, 1881-1934, and monthly procipitation, June 1929 to December 1931.
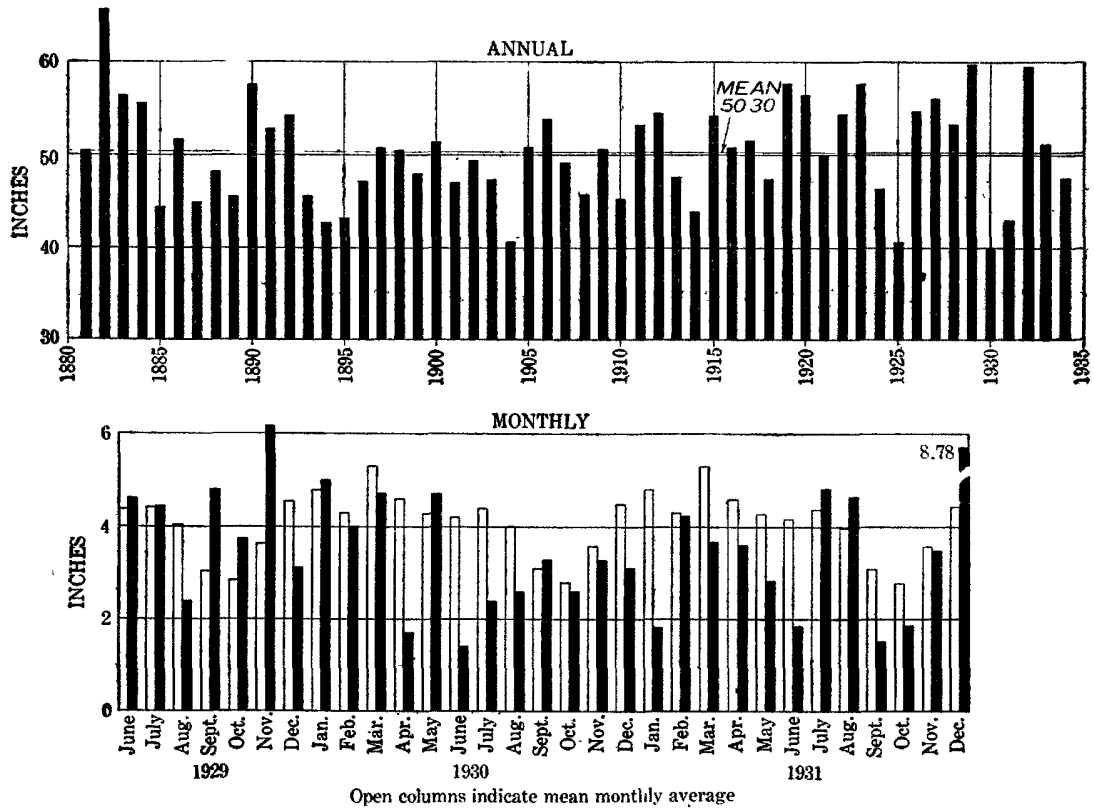

Frodkr 34.-Annual precipitation in Tennessee, 1881-1934, and monthly precipltation, June 1929 to December 1931. 

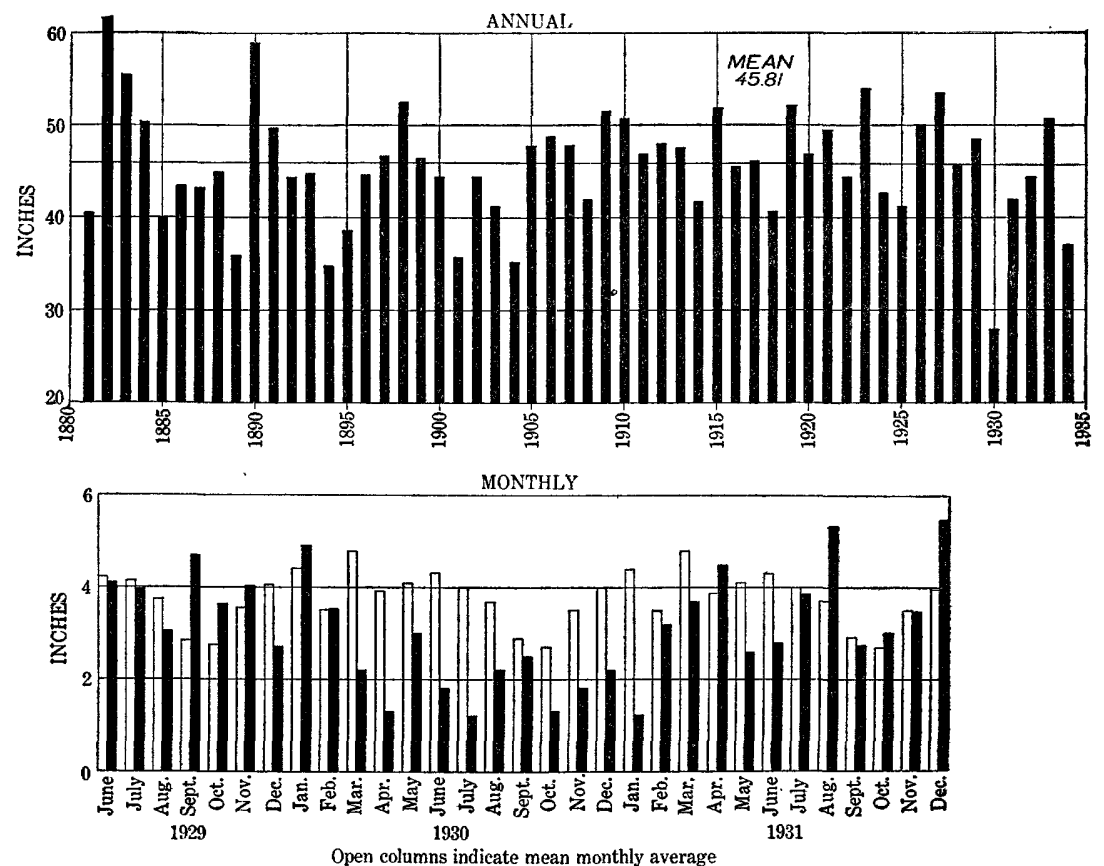

Frouke 35.-Annual precipitation in Kentucky, 1881-1934, and monthly precipitation, June 1929 to December 1931 .
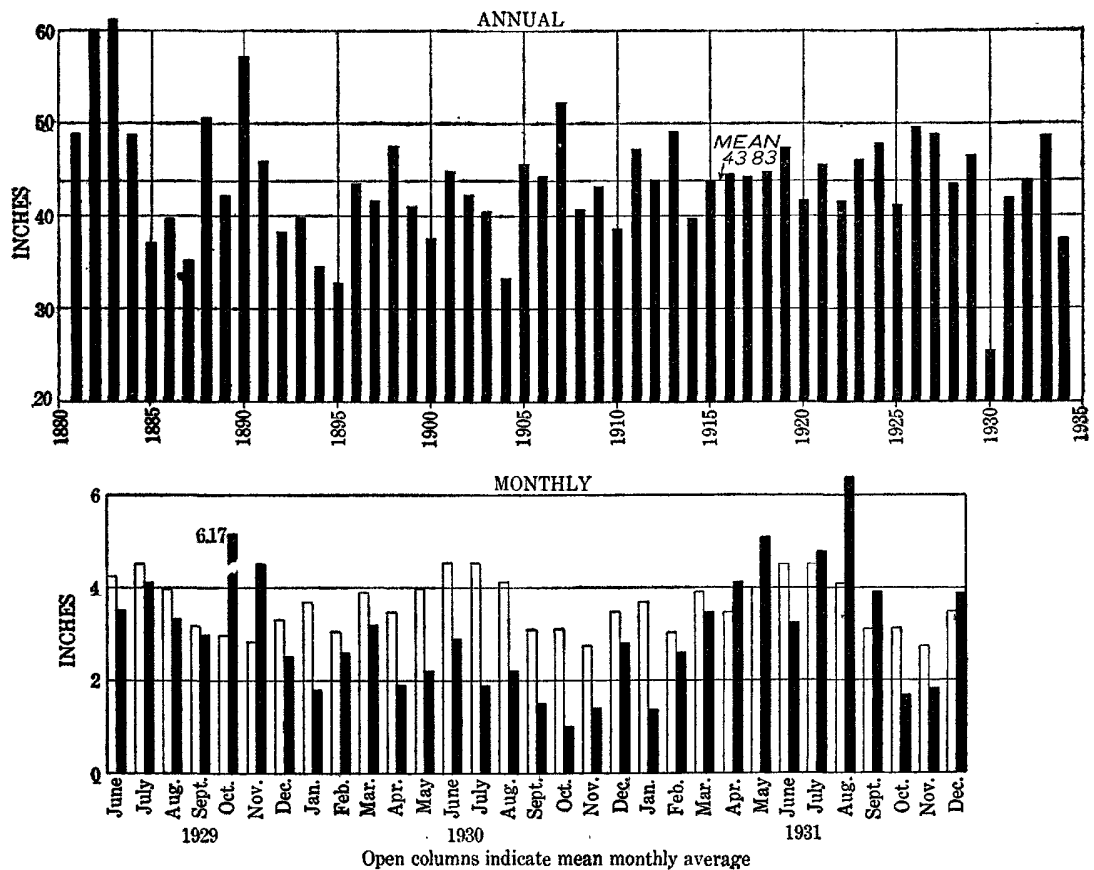

Floure 36.-Annual precipitation in West Virginia, 1881-1934, and monthly precipitation, June 1929 tc December 1931. 

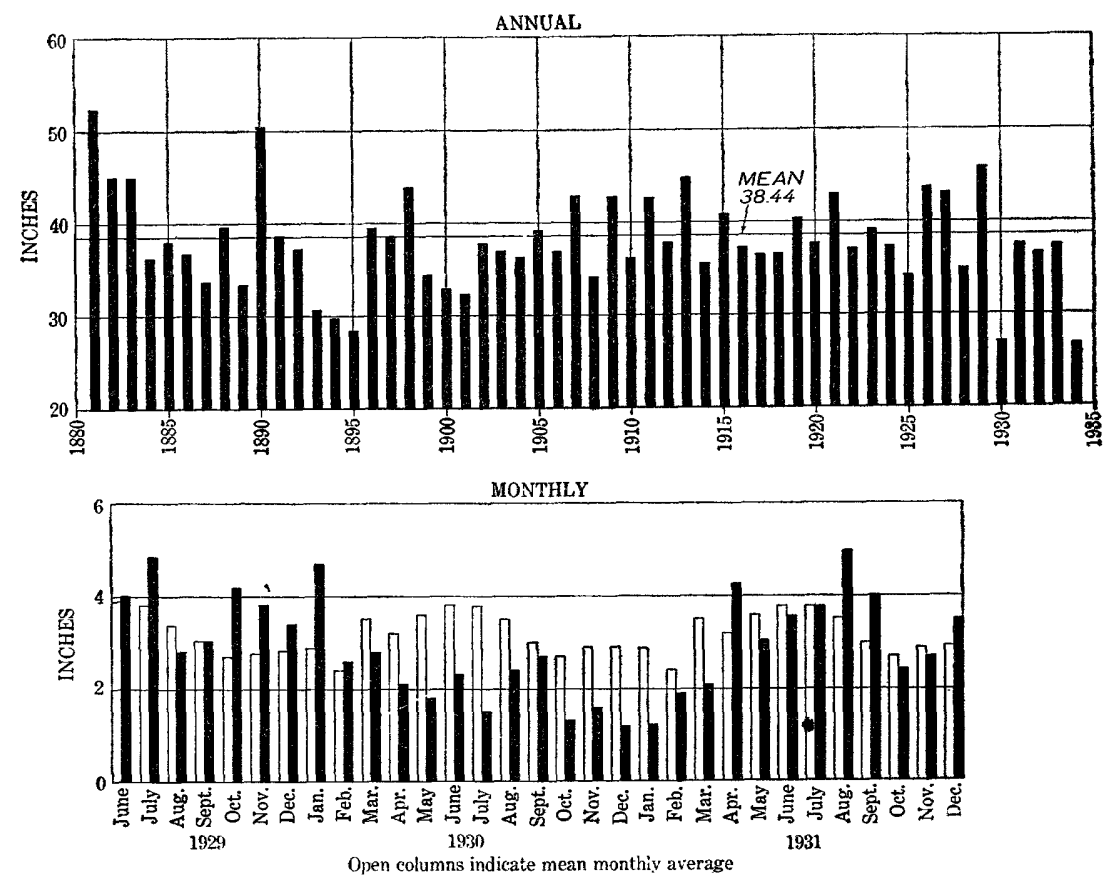

FIGURE 37.-Annual precipitation in Ohio, 1881-1934, and monthly precipitation, June 1929 to December 1931.

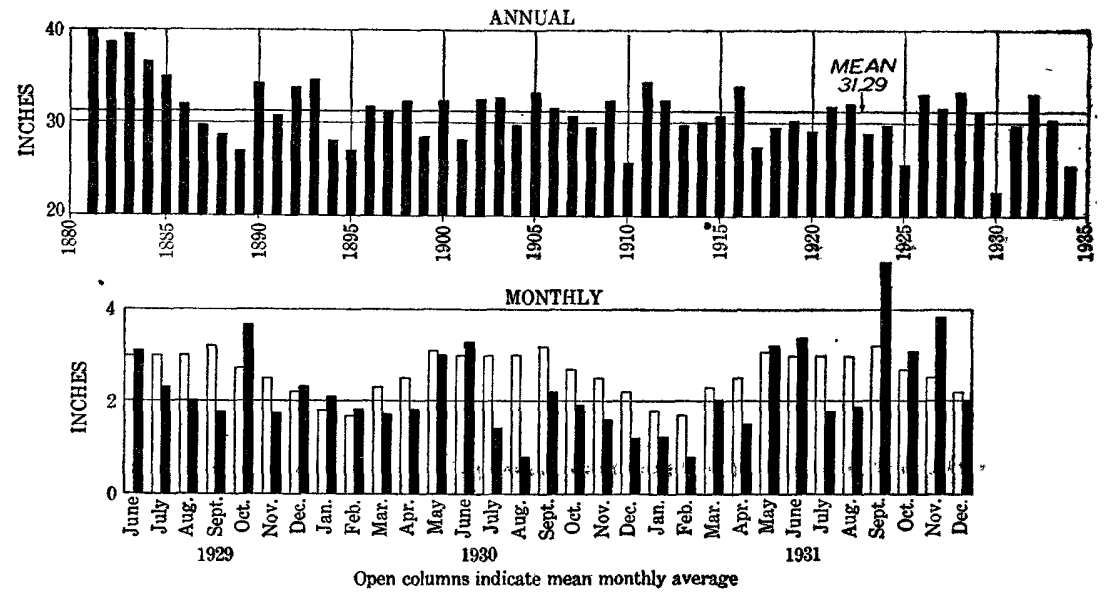

FIGURE 38.-Annual precipitation in Michigan, 1881-1934, and monthly precipitation, June 1929 to December 1931 . 

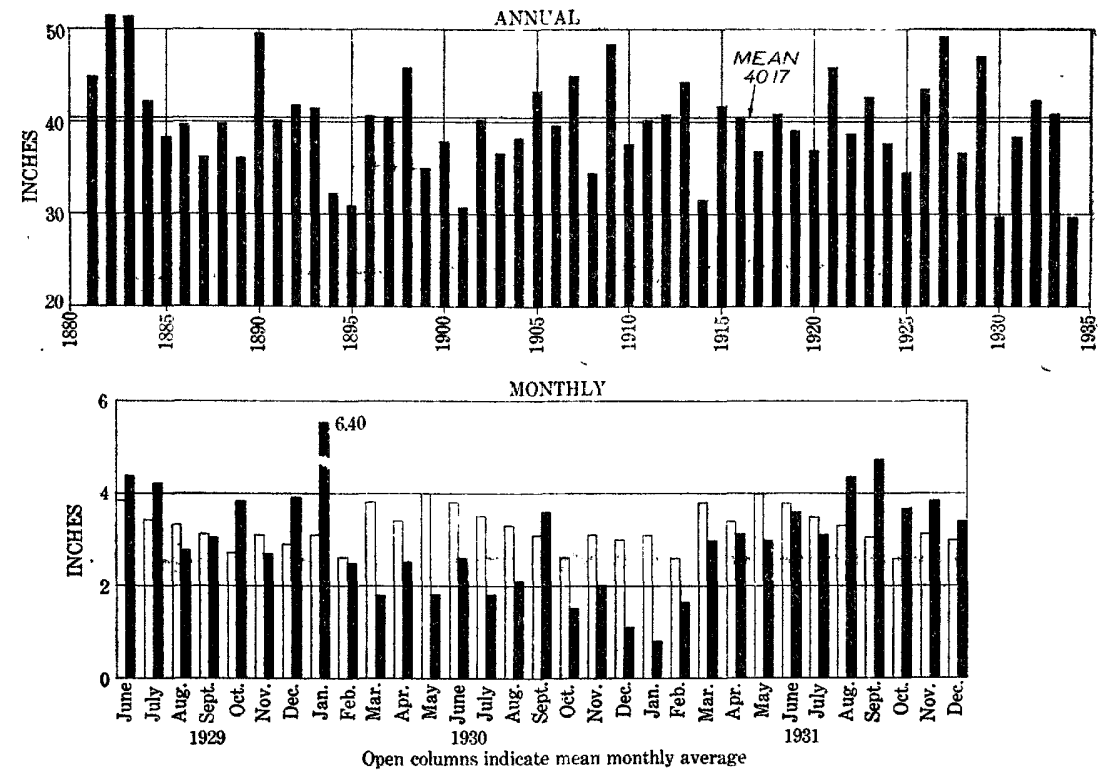

Figure 39.-Annual precipitation in Indiana, 1881-1934, and monthly precipitation, June 1929 to December 1931.
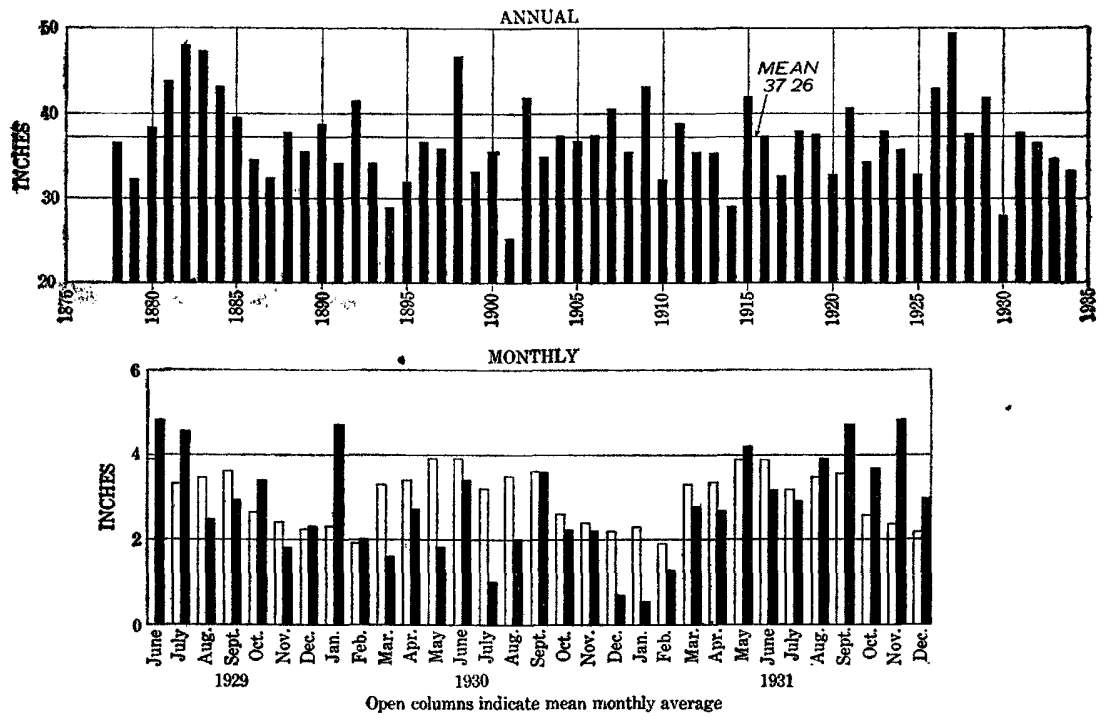

FroukE 40.-Annual precipitation in minois, 1878-1934, and monthly precipitation, June 1929 to Decomber 1931 . 

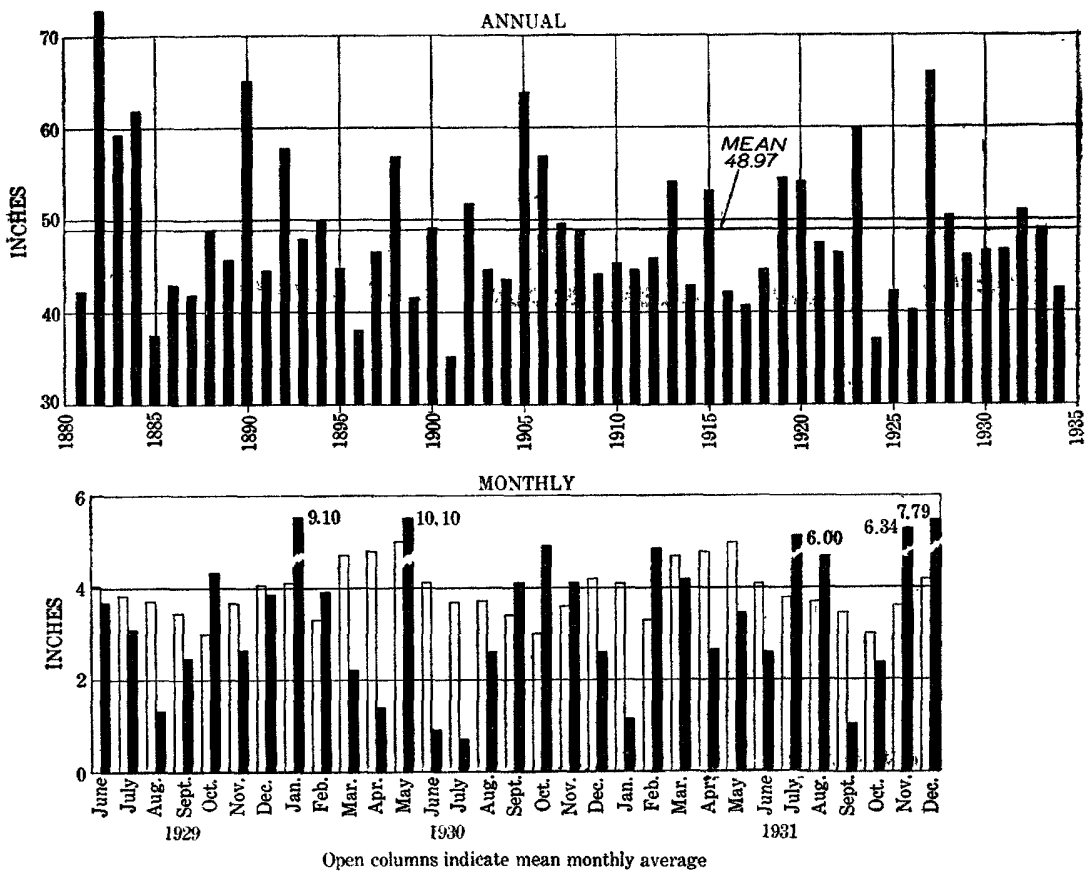

Froure 41.-Annual precipitation in Arkansas, 1881-1934, and monthly precipitation, June 1929 to December 1931.
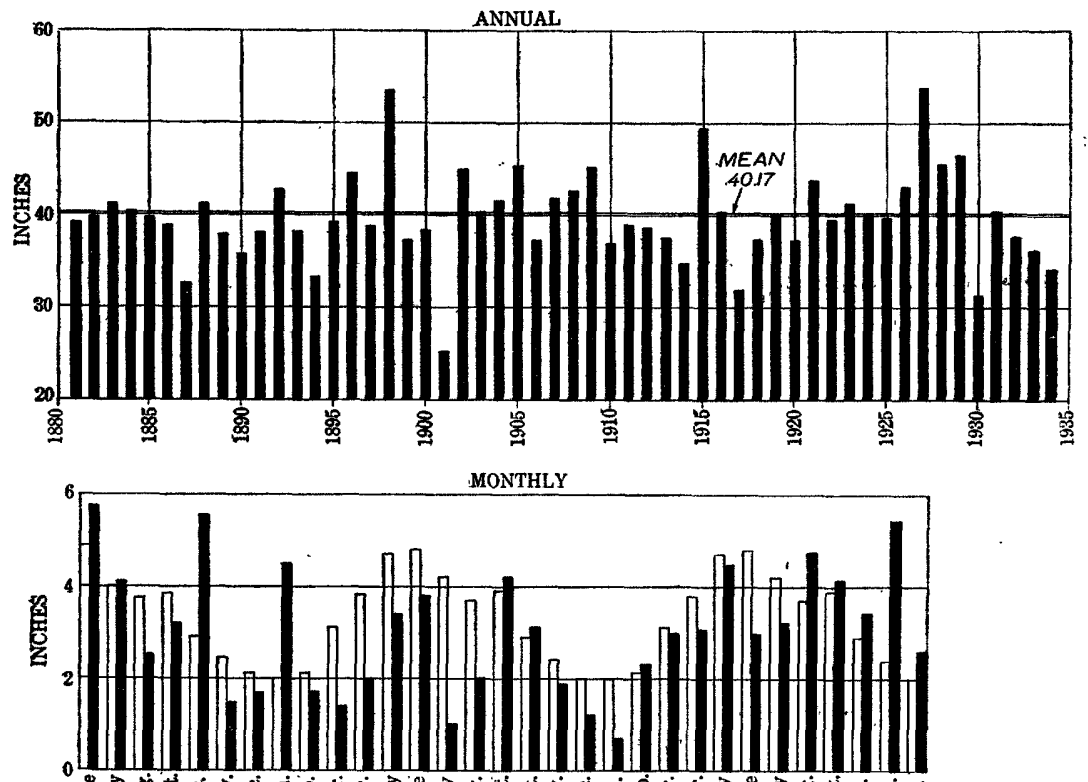

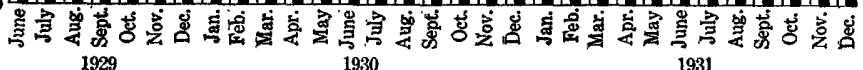

Open columns indicate mean monthly average

Figone 42.-Annual precipitation in Missouri, 1881-1934, and monthly precipitation, Junc 1929 to December 1931. 

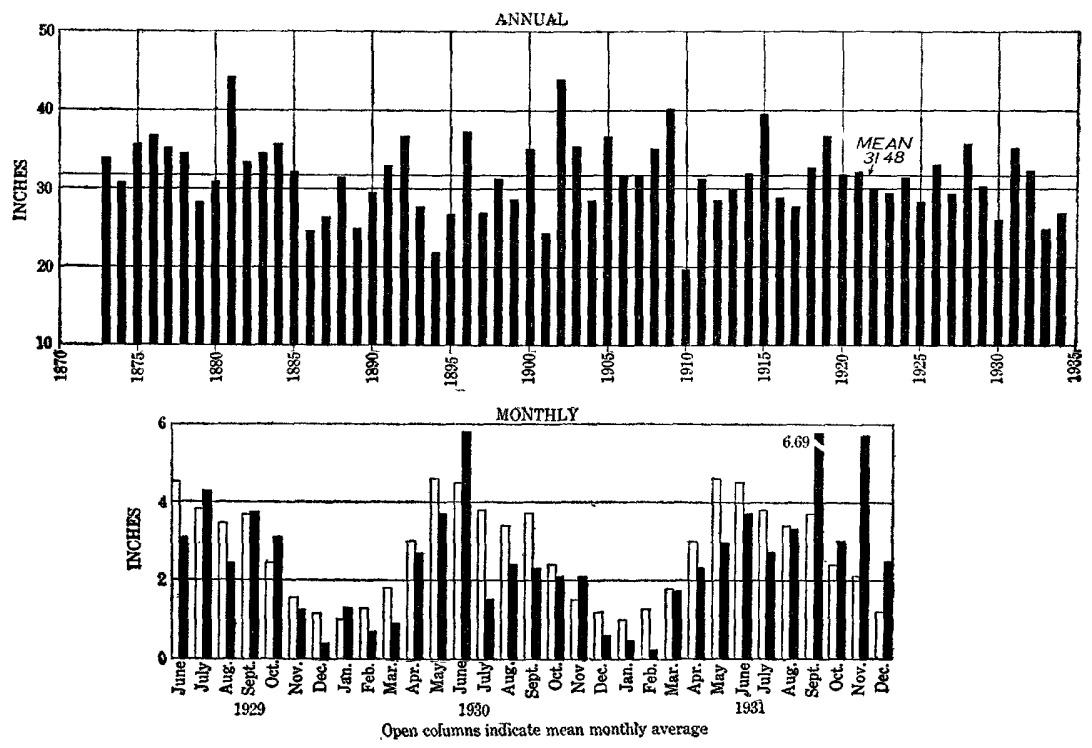

FIoUne 43.-Annual precipitation in lowa, 1873-1934, and montbly precipitation, June 1929 to December 1931.

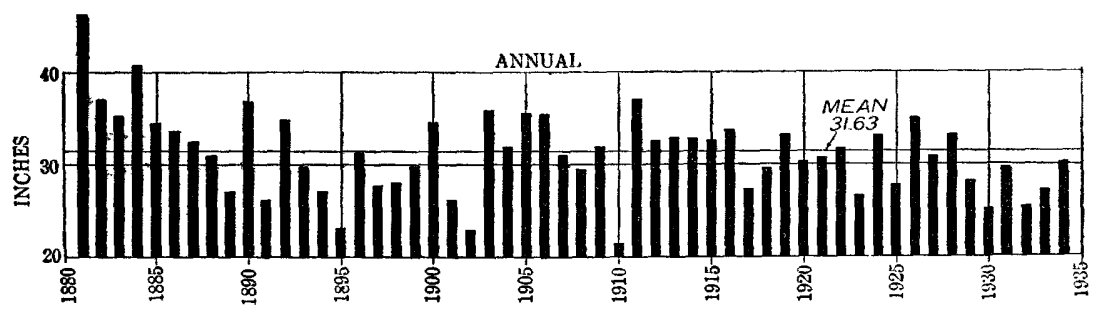

MONTHLY

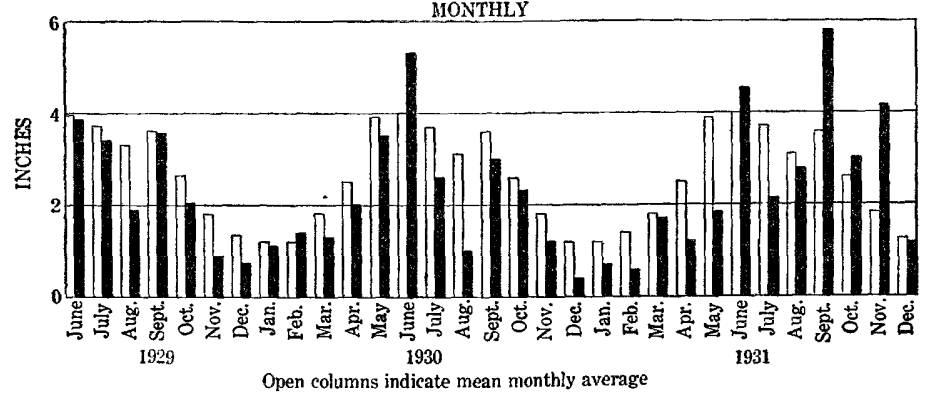

Figure 44.-Annual precipitation in Wisconsin, 1881-1934, and monthly precipitation, June 1929 to Decomber 1931. 

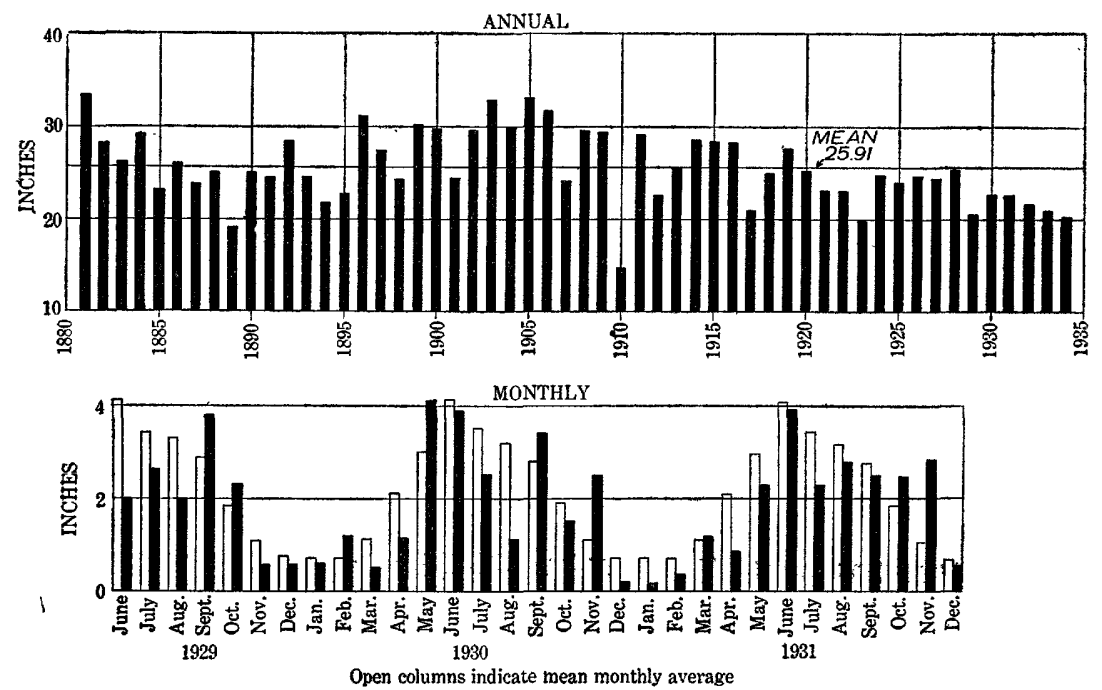

Fraure 45.-Annual precipitation in Minnesota, 1881-1934, and monthly precipitation, June 1920 to December 1931.
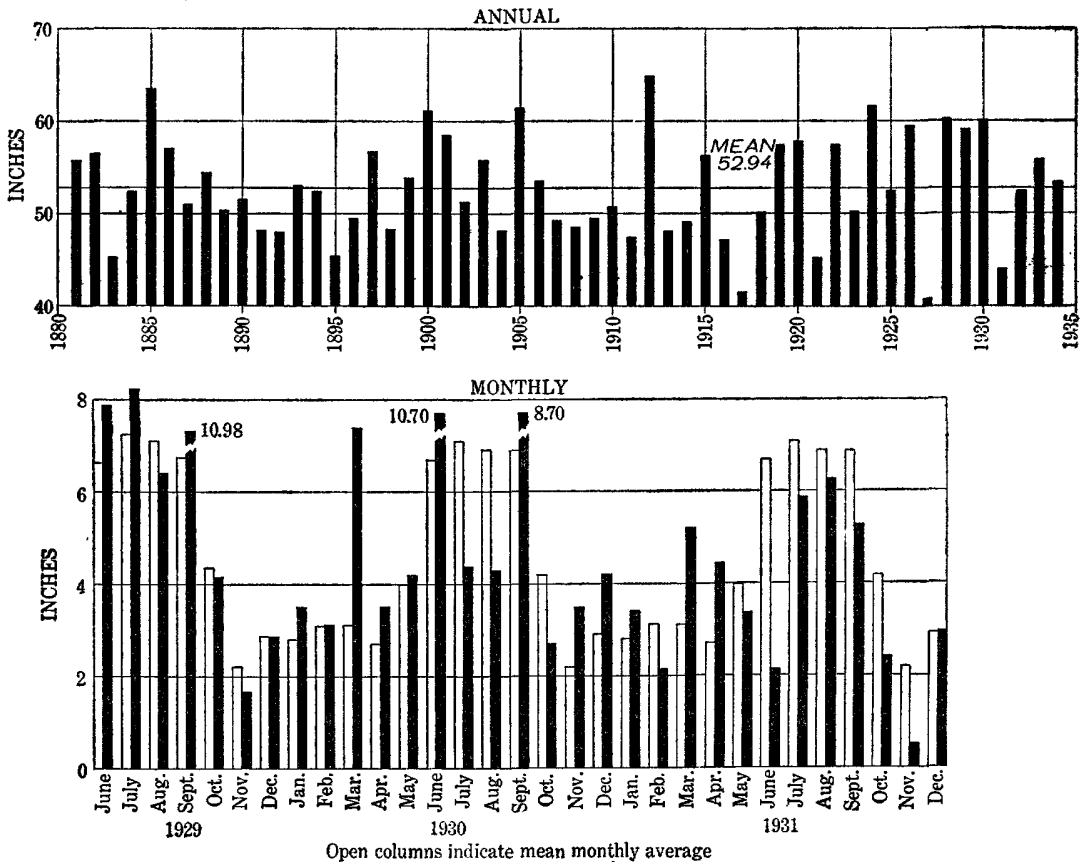

FraURe 46.-Annual precipitation in Florida, 1881-1934, and monthly precipitation, June 1929 to December 1931 . 

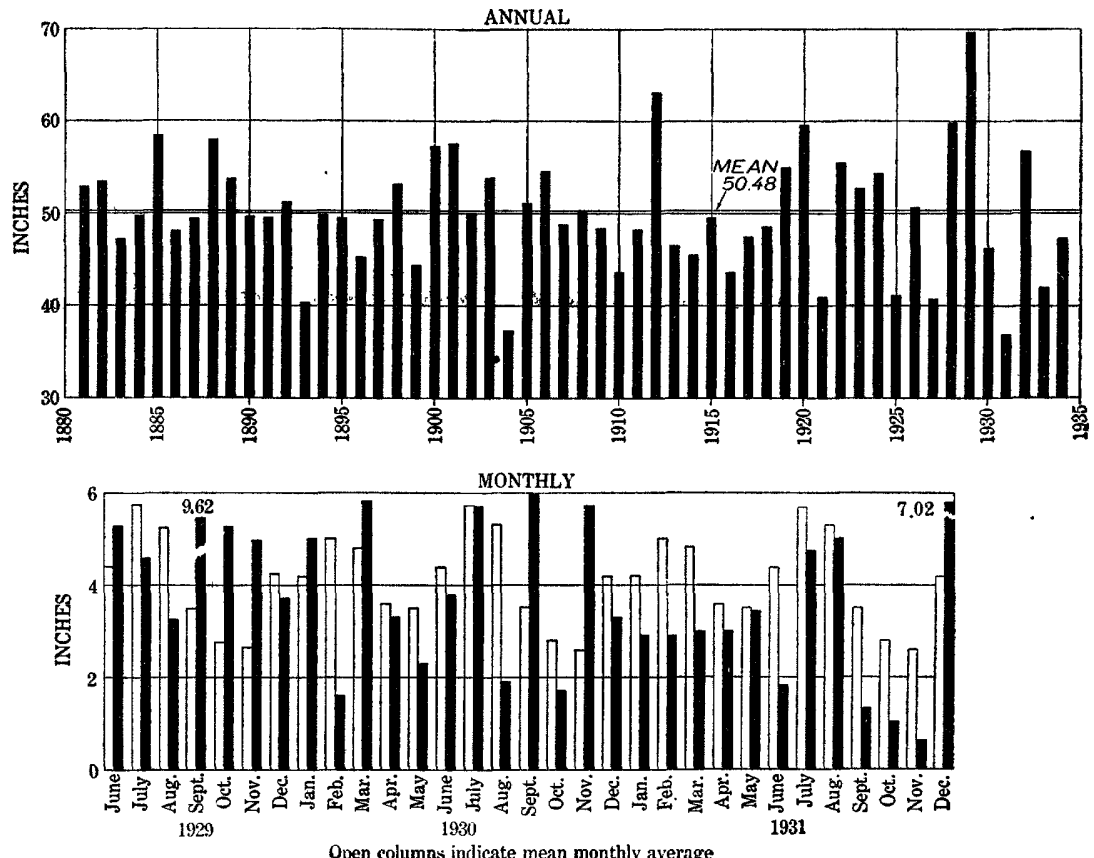

Floura 47.-Annual precipitation in Georgia, 1881-1934, and monthly precipitation, June 1820_to December 1931. 


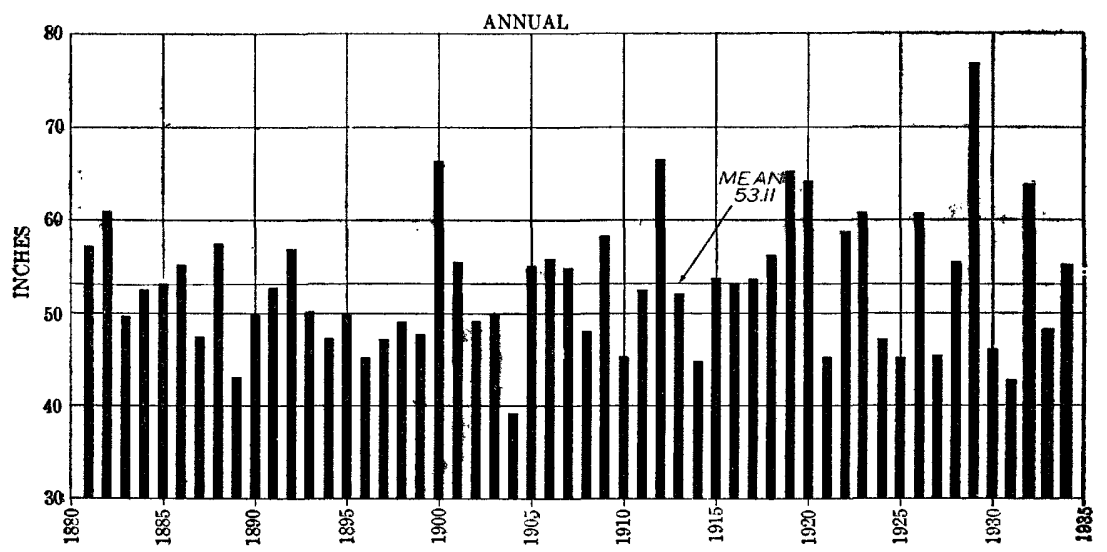

MONTHLY

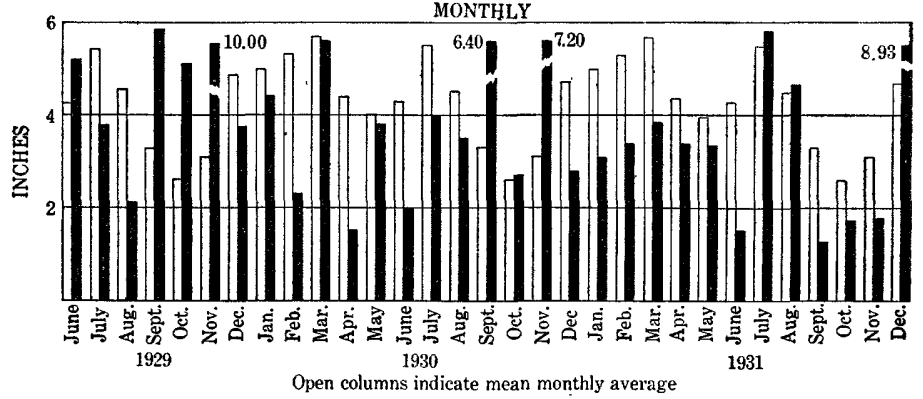

FigURE 48.-Annual precipitation in Alabama, 1881-1934, and monthly precipitation, June 1929 to December 1931. 

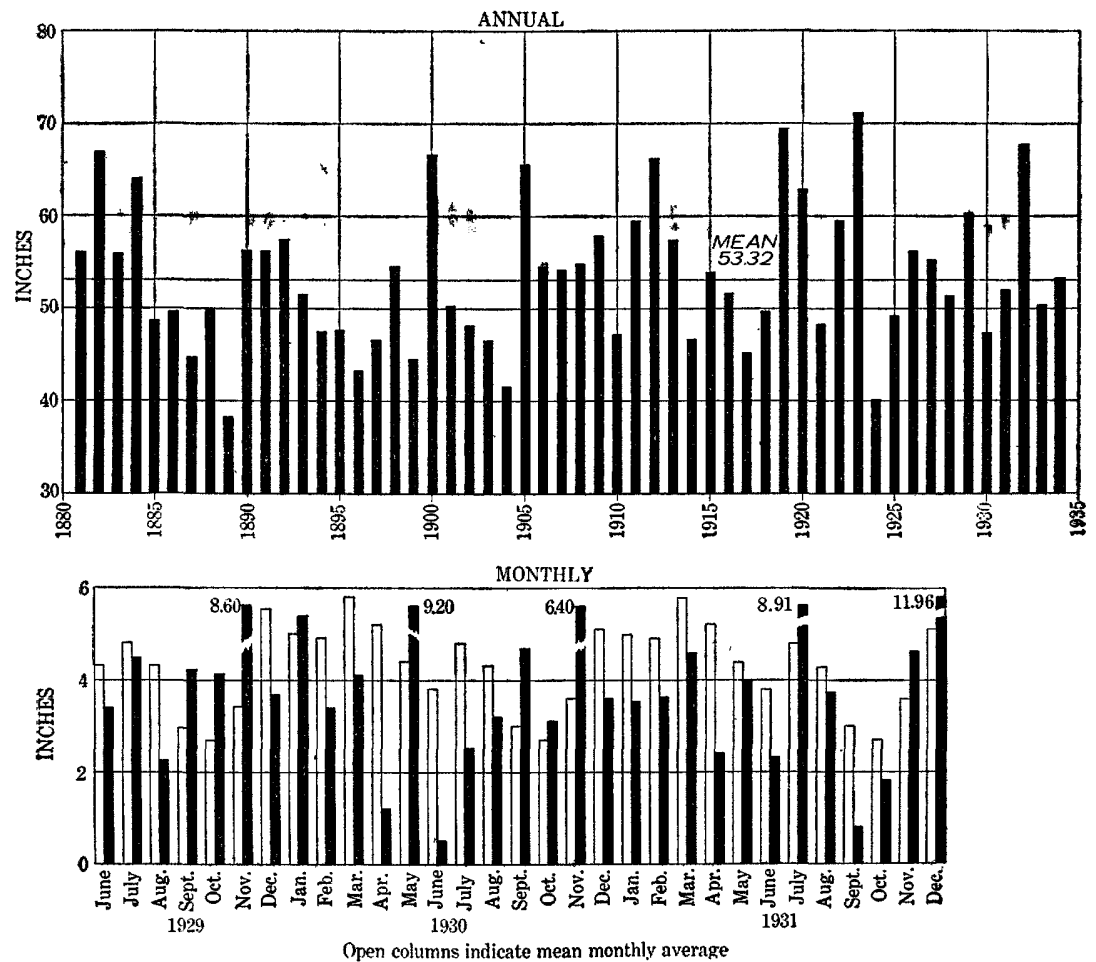

Figura 49.-Annual precipitation in Mississippi, 1881-1934, and monthly precipitation, June 1929 to December 1931. 

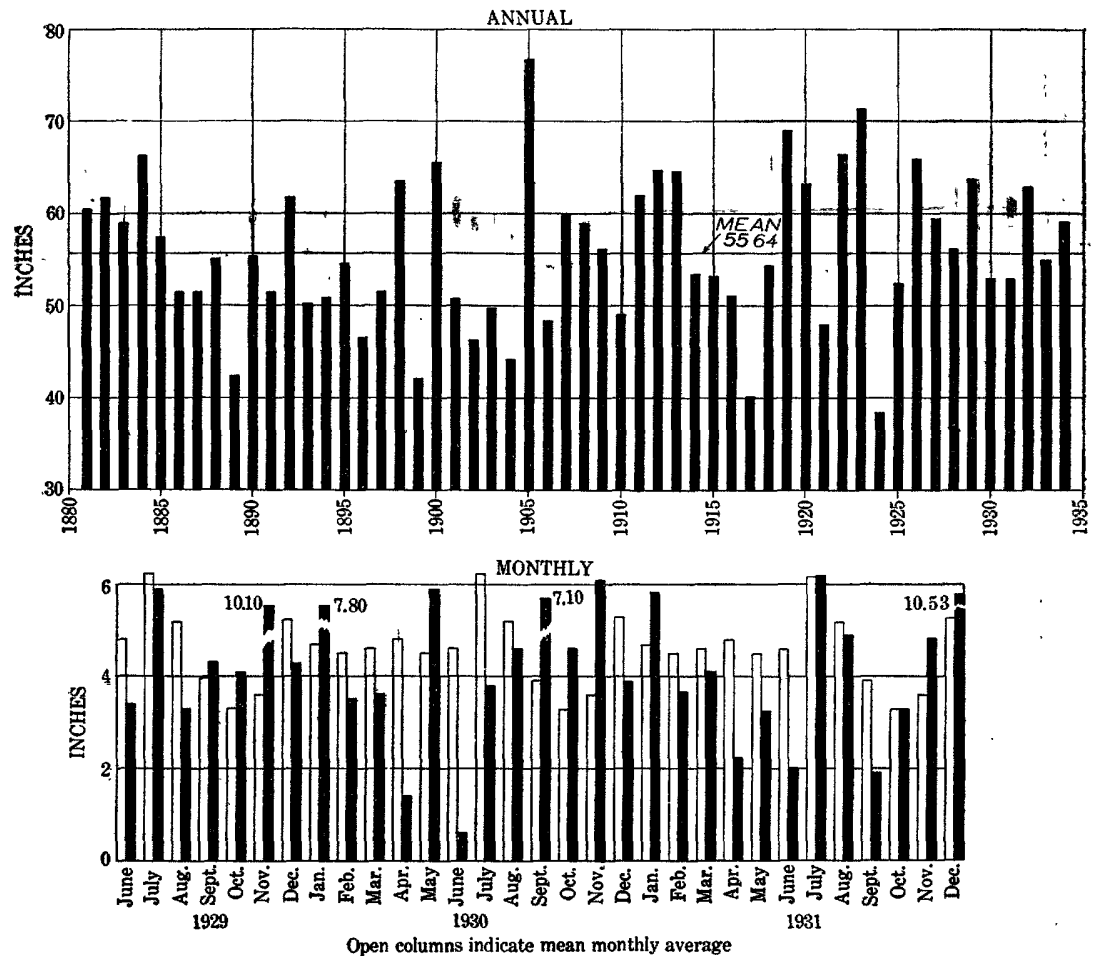

FroURE 50.-Annual precipitation in Louisians, 1881-1984, and monthly precipitation, June 1929 to December 1931. 

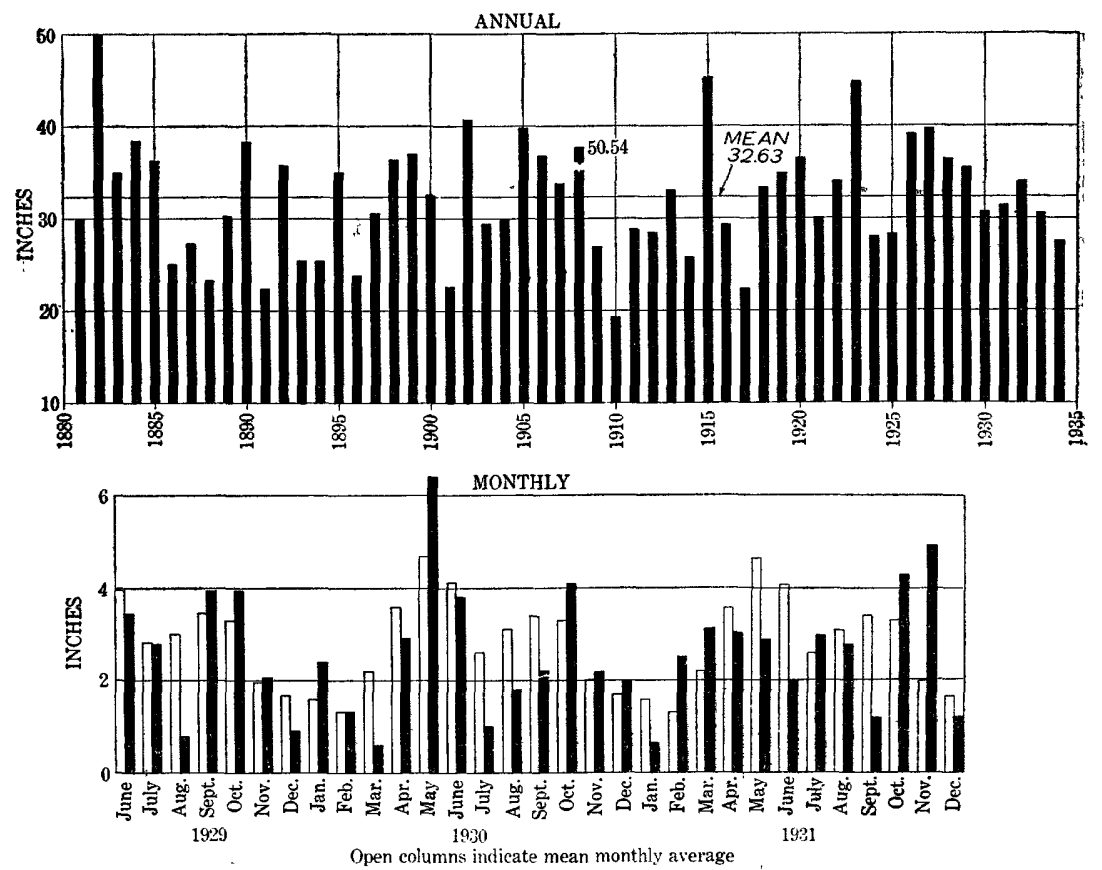

FIGURE 51-Annual precipitation in Oklahoma, 1881-1934, and monthly precipitation, June 1929 to. December 1931.
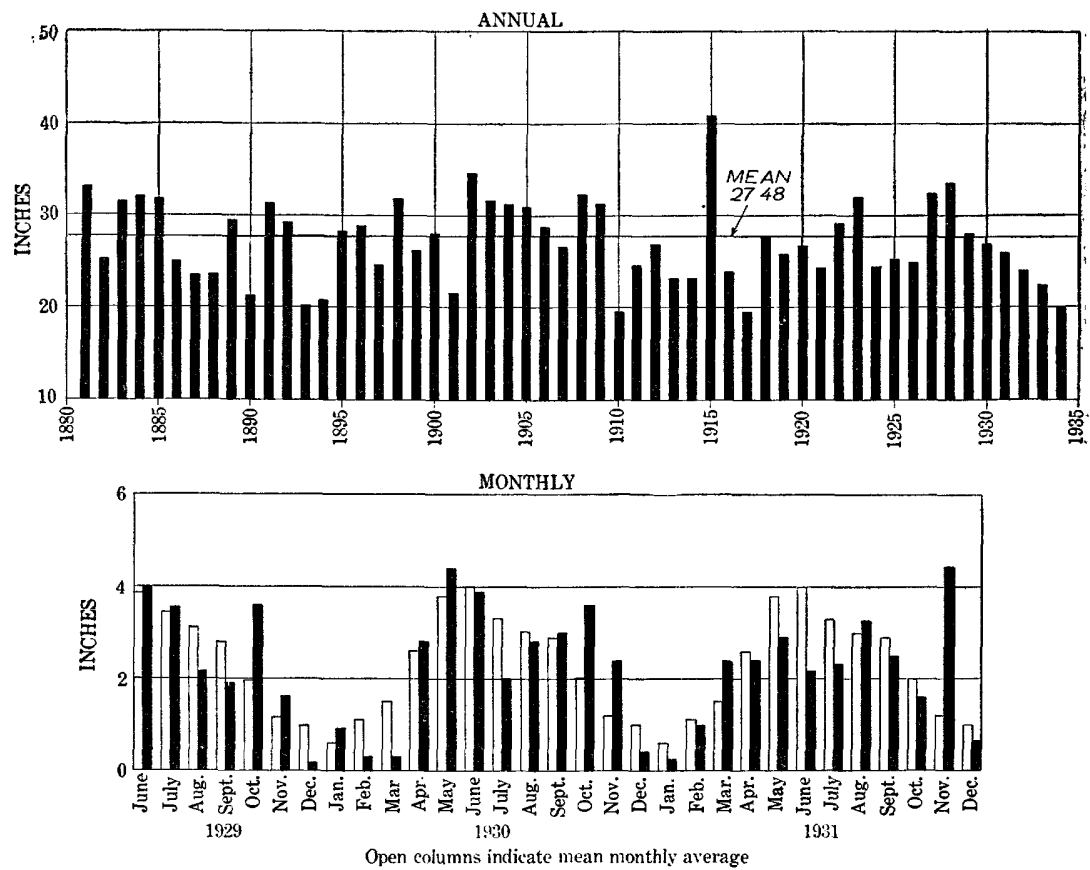

FIGURE 52.-Annual precipitation in Kansas, 1881-1934, and monthly precipitation, June 1929 to December 1931. 

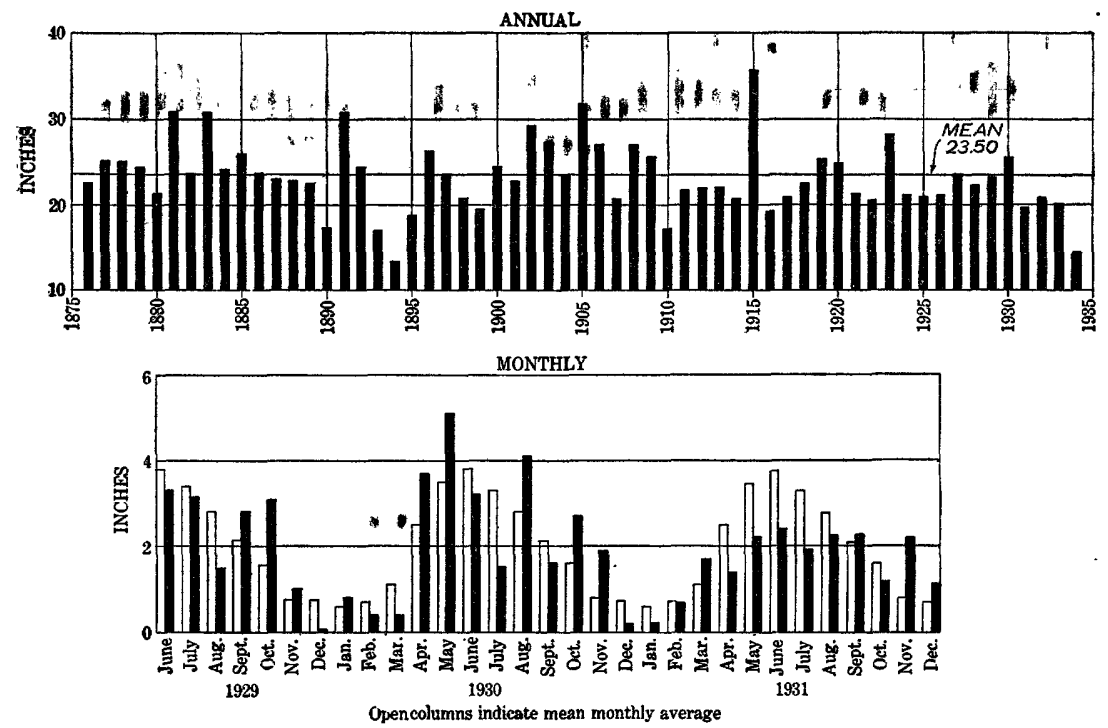

TraURE 53.-Annual precipitation in Nebraska, 1876-1934, and monthly precipitation, June 1929 to December 1931.

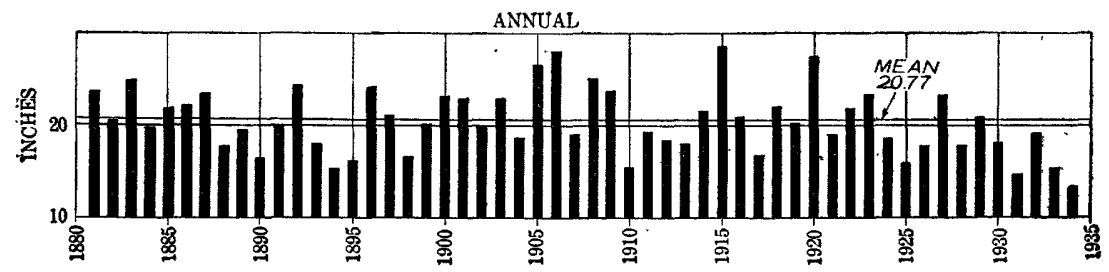

MONTHLY

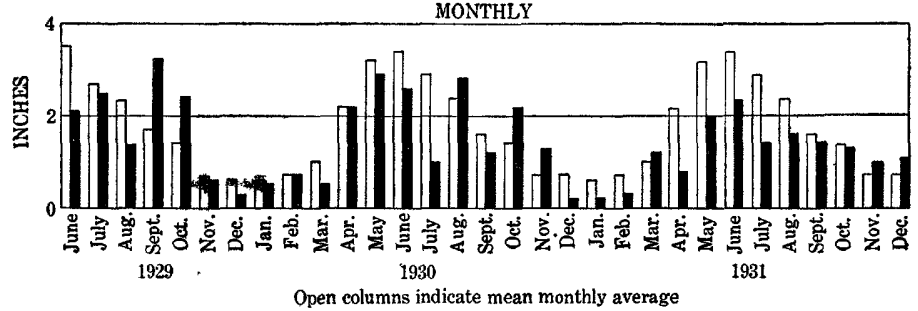

Frauke 54.-Annual precipitation in South Dakota, 1881-1934, and monthly precipitation, June 1929 to December 1931. 

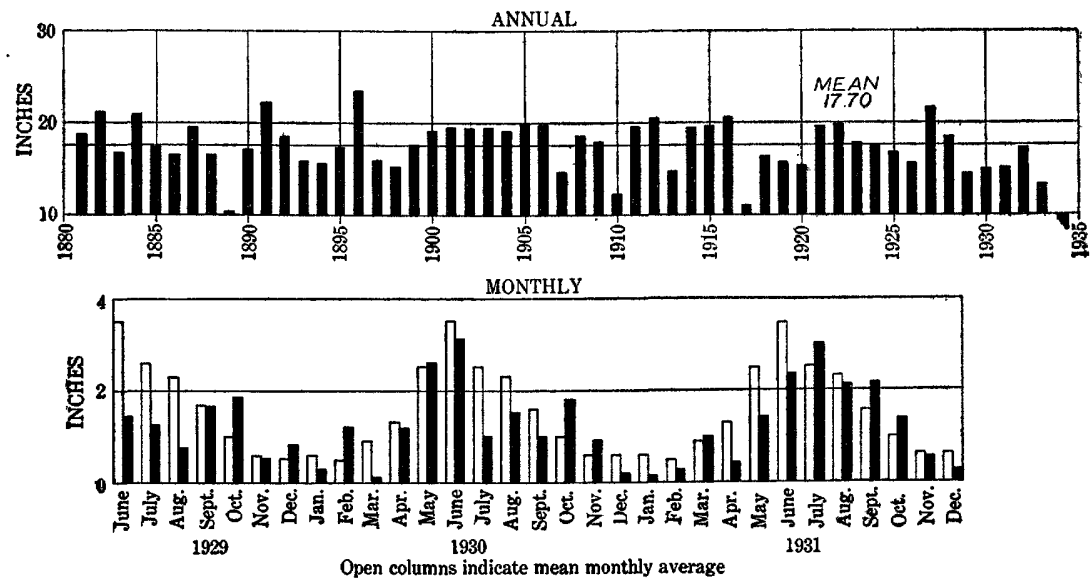

Froure 55.-Annual precipitation in North Dakota, 1881-1934, and monthly precipitation, June 1929 to December 1931.
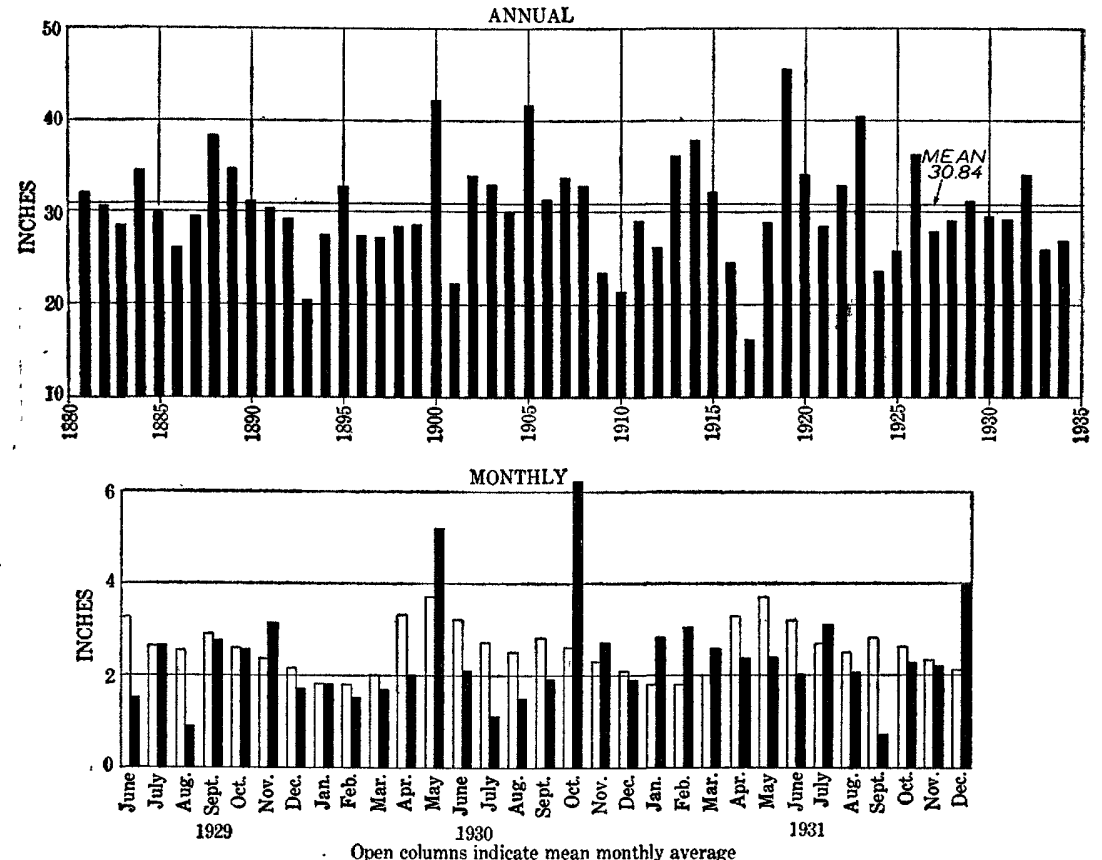

FIGURE 56.-Annual precipitation in Texas, 1881-1934, and monthly precipitation, June 1929 to December 1931. 


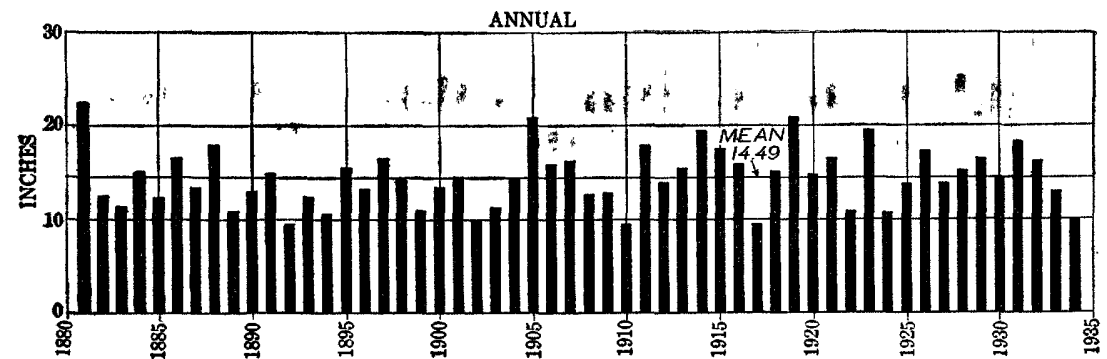

MONTHLY

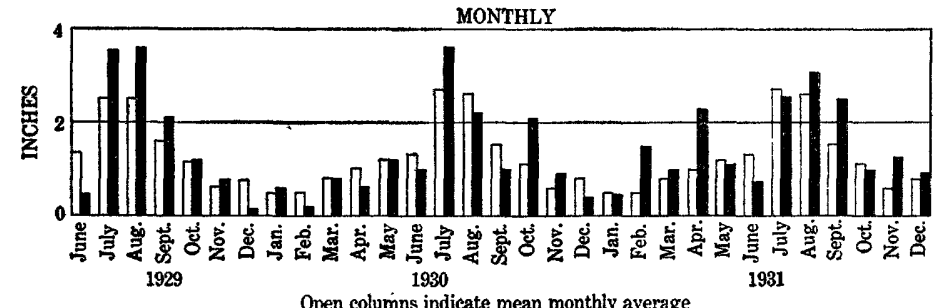

Fogdre 57.-Annual precipitation in New Mexico, 1881-1934, and monthly precipitation, June 1929 to December 1931.

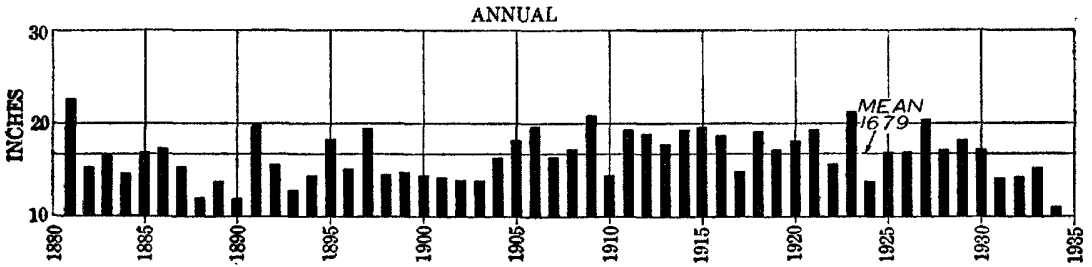

MONTHLY

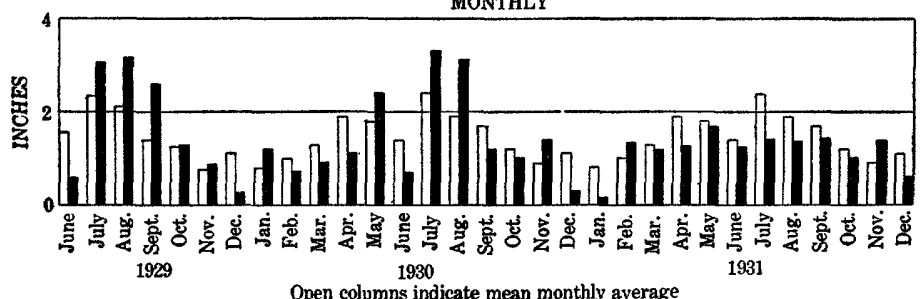

FIGURe 58.-Annual precipitation in Colorado, 1881-1934, and monthly precipitation, June 1929 to December 1931. 


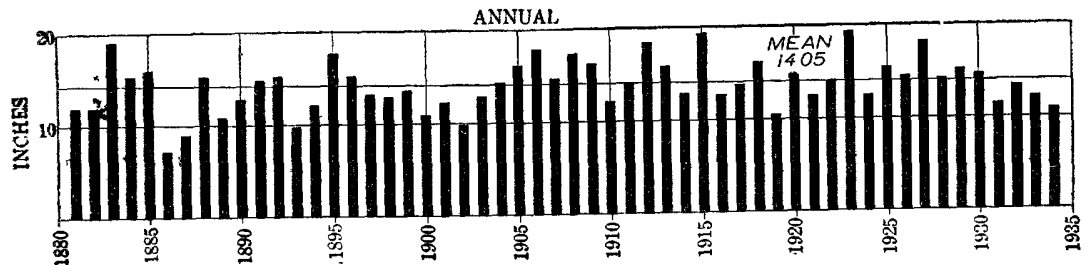

MONTHLY

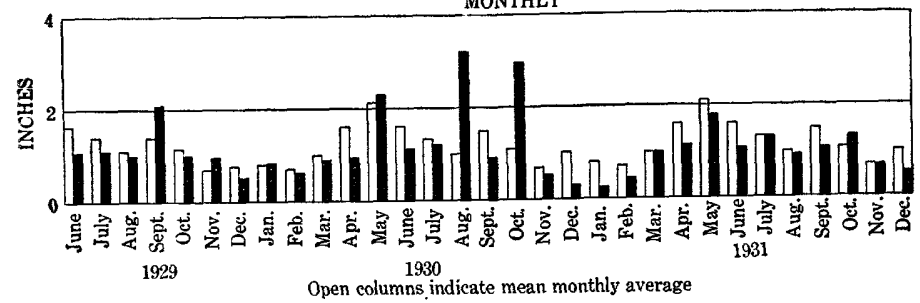

Foure 59.-Annual precipitation in Wyoming, 1881-1934, and monthly precipitation, June 1929 to December 1931.
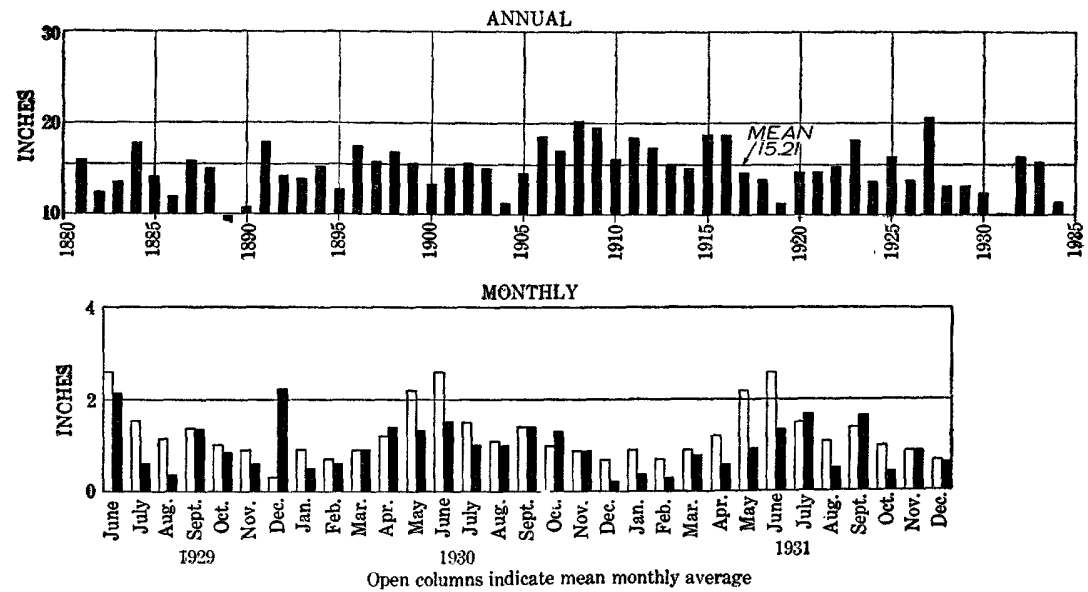

Figure 60.-Annual precipitation in Montana, 1881-1934, and monthly precipitation, June 1929 to December 1931. 

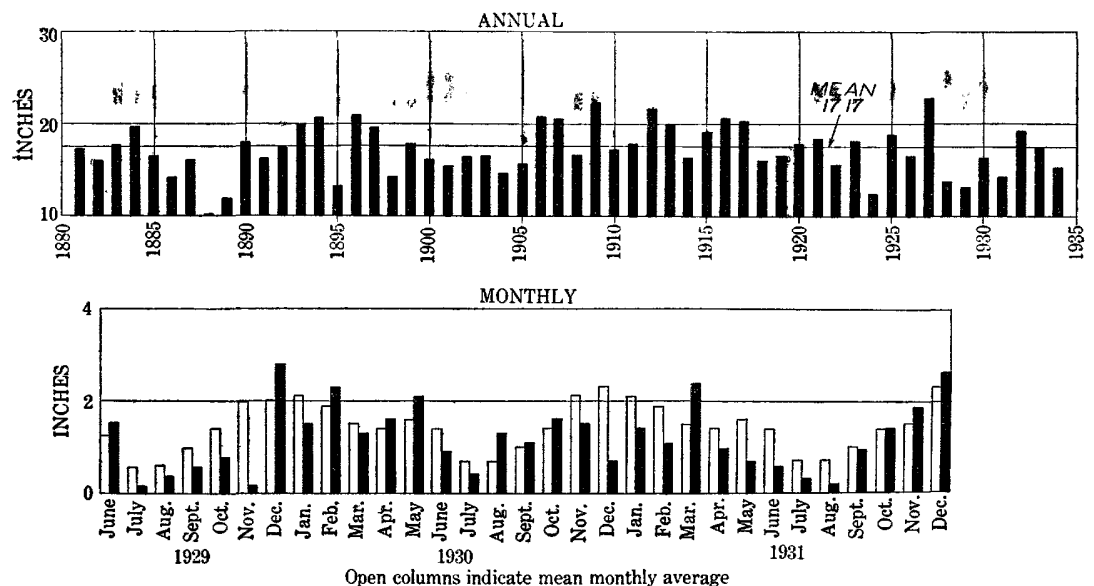

FIGURE 61.-Annual precipitation in Idaho, 1881-1934, and monthly precipitation, June 1929 to December 1931 .
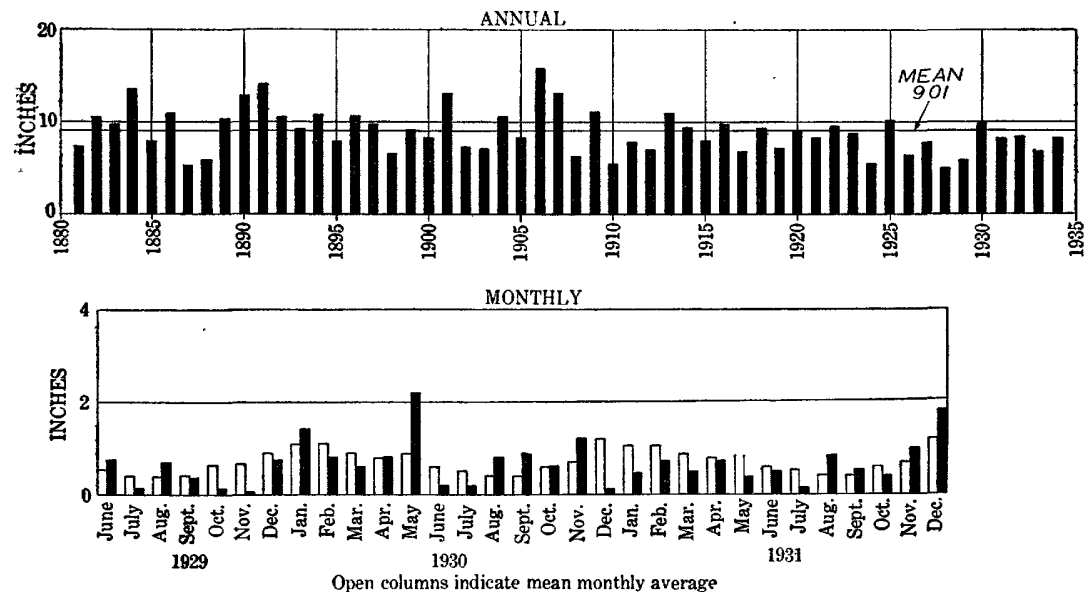

FIGURE 62.-Annual precipitation in Nevada, 1881-1934, and monthly precipitation, June 1929 to December 1931. 

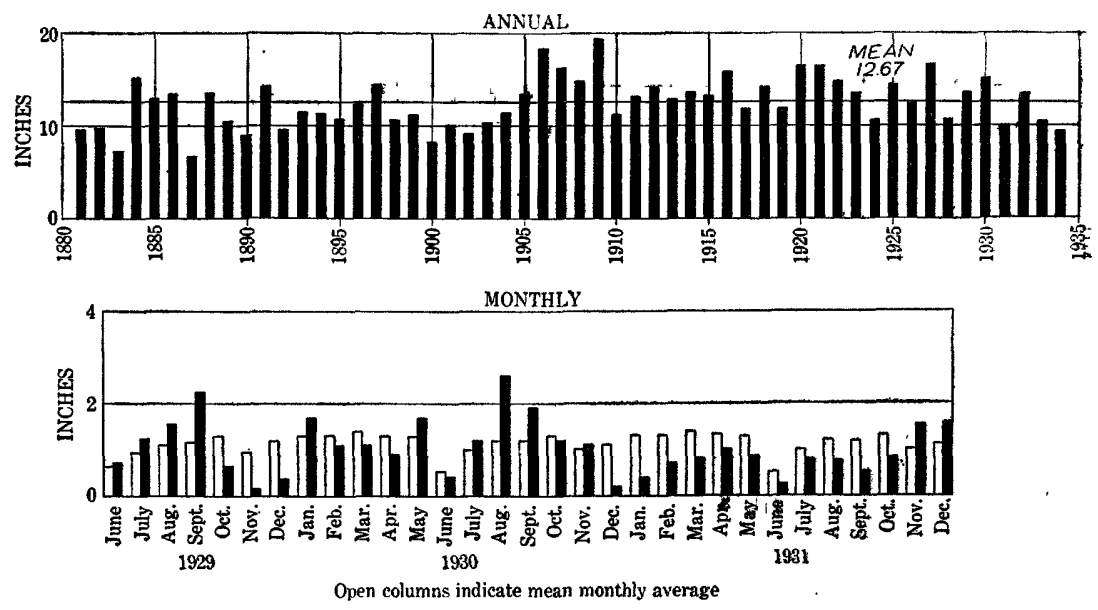

FIGURE 63.-Annual precipitation in Utah, 1881-1934, and monthly precipitation, June 1929 to. December 1931.
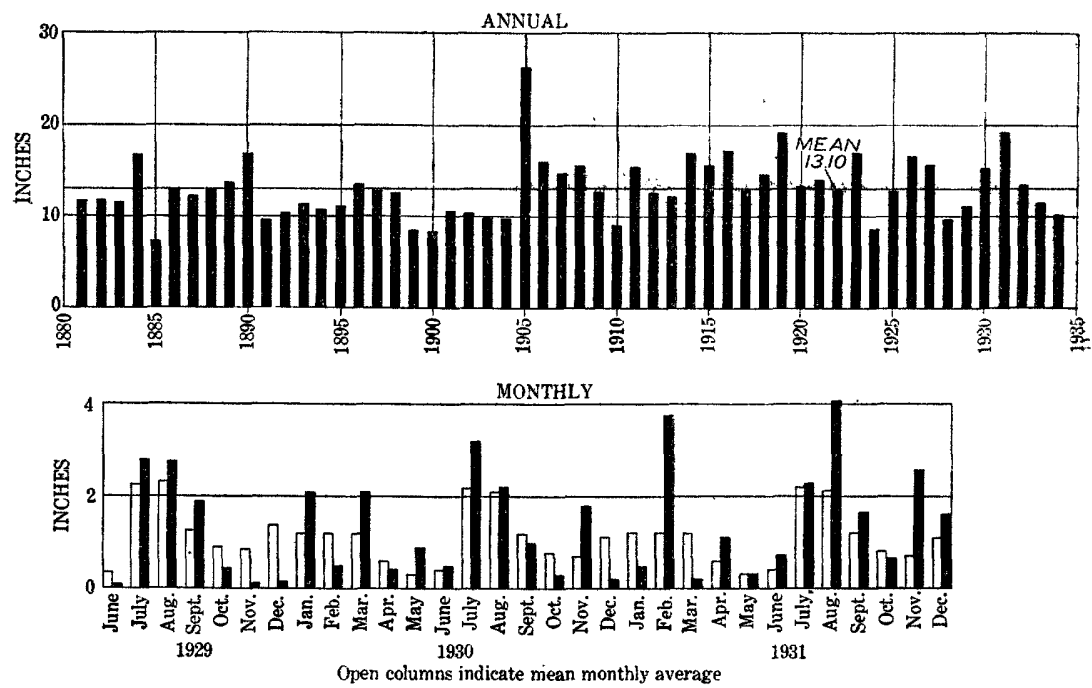

Froure 64.-Annual precipitation in Arizona, 1881-1934, and monthly precipitation, June 1920 to. December 1931. 


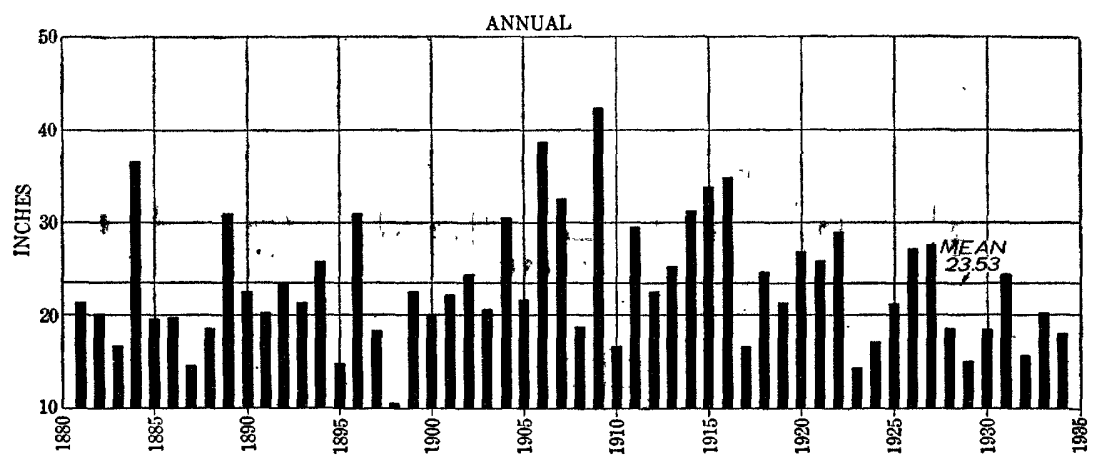

MONTHLY

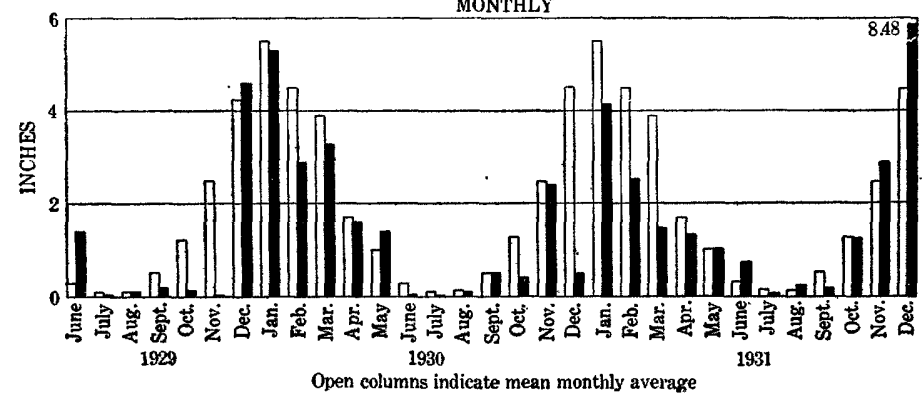

Flgure 65.-Annual precipitation in California, 1881-1934, and monthly precipitation, June 1929 to December 1931. 

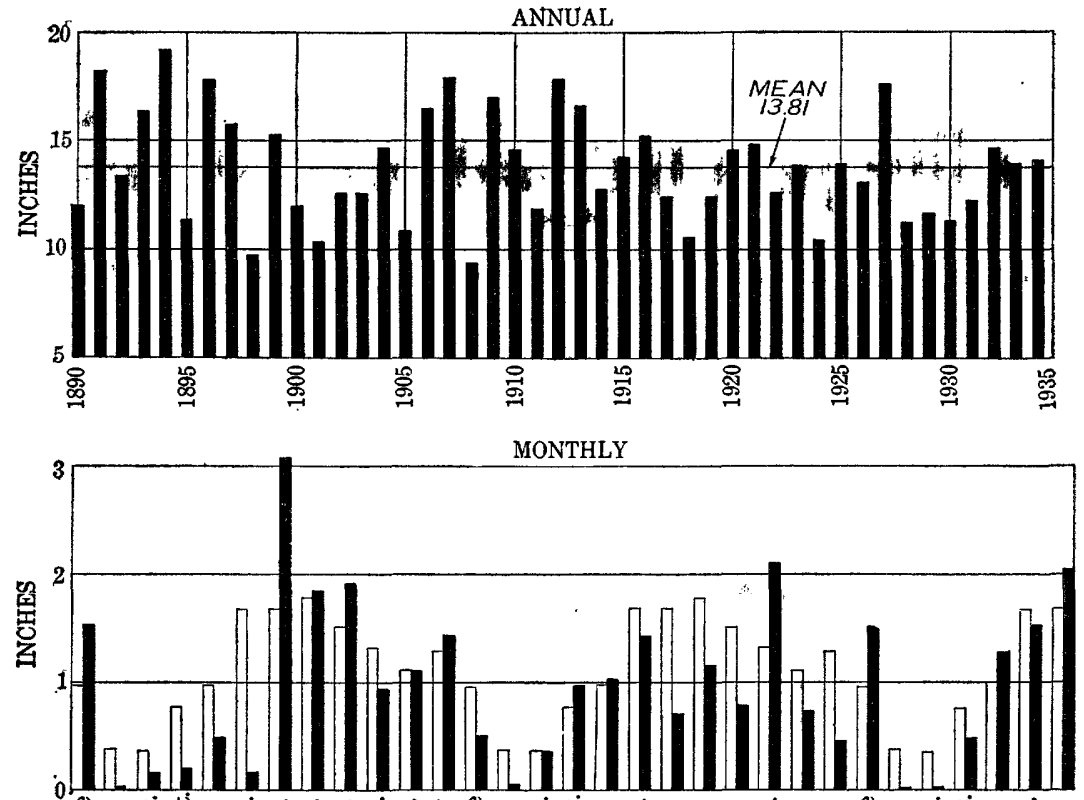

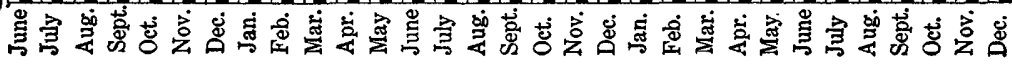
1929 1930 1931

Open columns indicate mean monthly average

Figure 66.-Annual precipitation in eastern Oregon, 1890-1934, and monthly precipitation, June 1929 to December 1931. 

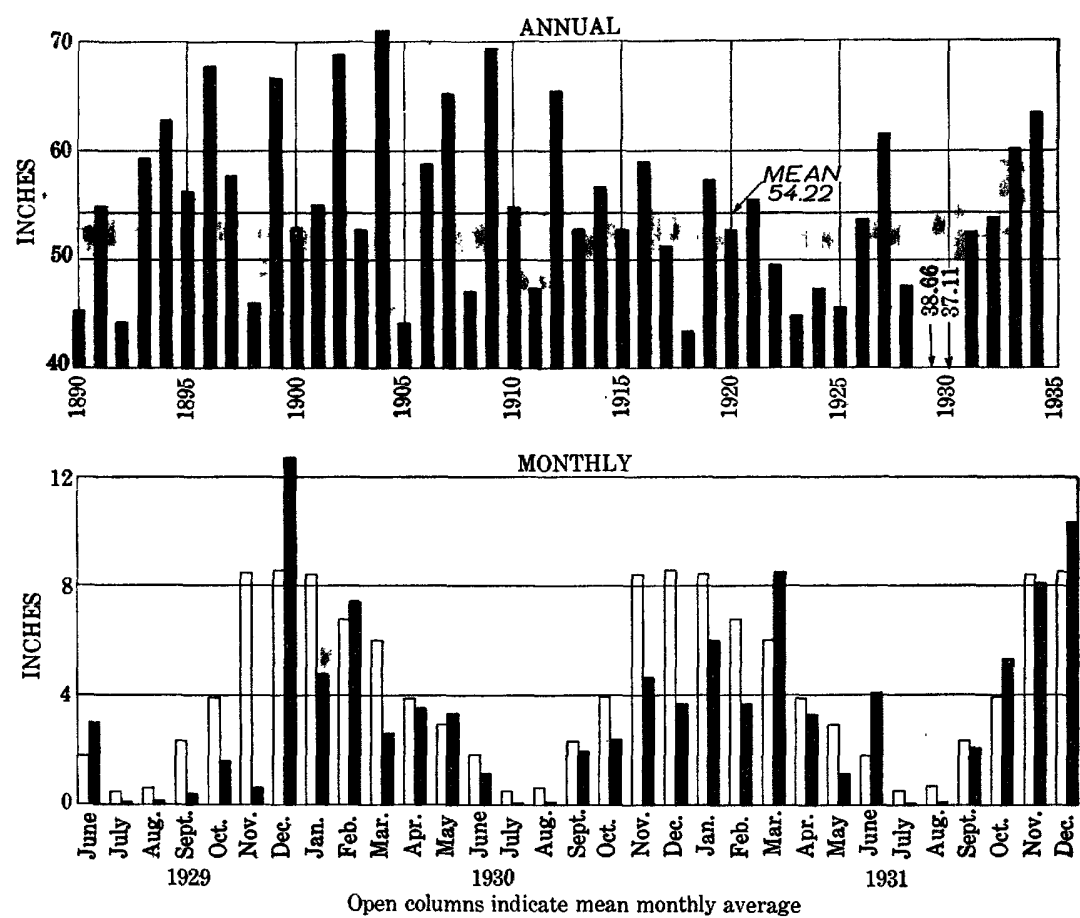

Figure 67.-Annual precipitation in western Oregon, 1890-1934, and monthly precipitation, June 1929 to December 1931. 

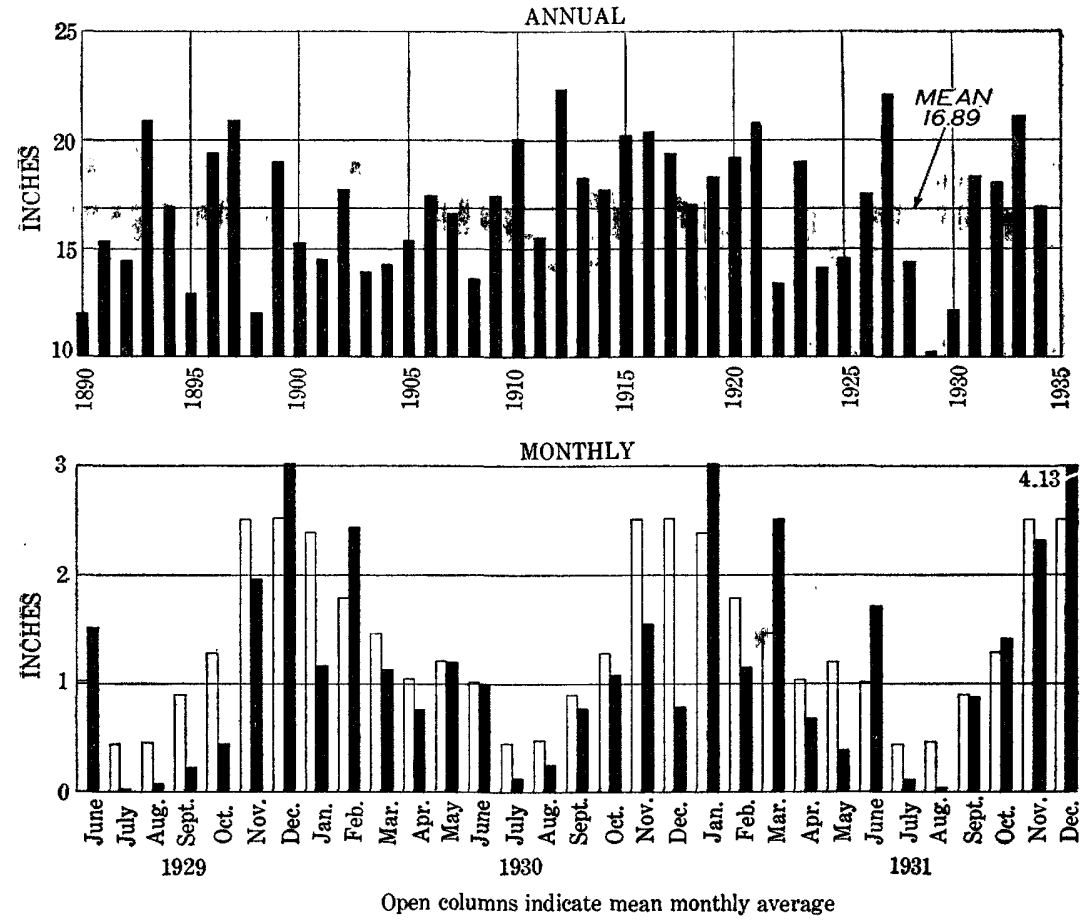

Foone 68.-Annual precipitation in eastern Washington, 1890-1984, and monthly precipitation, June 1929 to December 1931. 

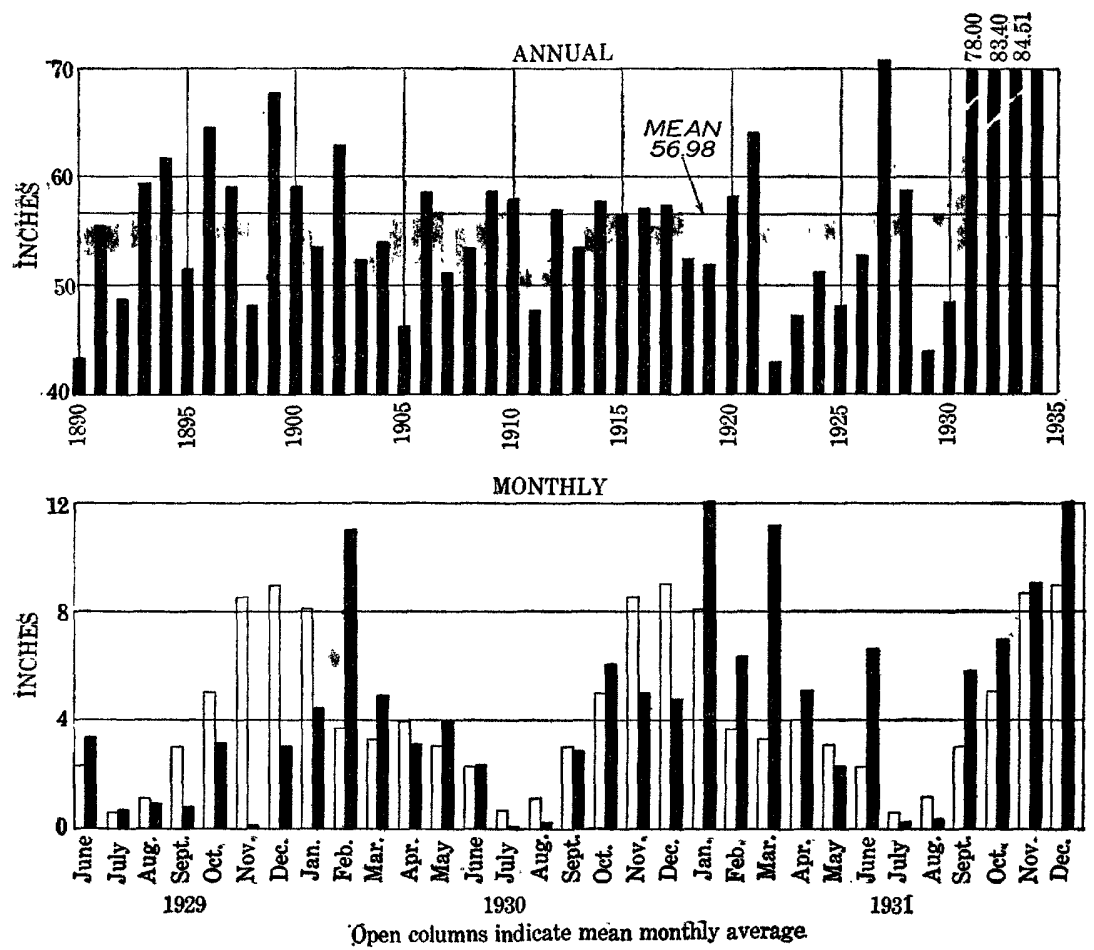

FJGURE 69,-Annual precipitation in western Washington, 1890-1934, and monthly precipitation, June 1929 to December 1931. 


\section{INDEX}

Page

Acknowledgments for aid

1-2

Agriculture, drought damage to.- 17-18, 32-35, 56-59 planning for alleviation of damage to. -.- 71-74

American National Red Cross, drought relief by.

Appropriations for drought relief, by American National Red Cross. .......... 41-45 by Congress........................ 38, 42, 62, 64-65

Arid States, alleviation of drought damage in. 71-74 crop yields in .................. 9, 33, 49,57-58 precipitation in, tables showing...... 4, $9,49,66$ vegetation in, water requirements of ....- 16-18 years of severe drought in

(tables 14 and 15), 68-69, pl. 1

Atmospheric pressure, fluctuations of water table in response to

Bird refuges, development of $61-64$

Carry-over effect of droughts $30-32,70-71$ Climate, fluctuations of, in California since

1769. $68-69$ general conditions of, causing drought.... 4 , $6,46,71$

Conservation of water supplies, planning for. $62-64$,

Crops, carry-over effects of drought on ...... 70 climatic factors affecting...... 11-18, 32-35, 57, 68 yield in relation to precipitation, in 1930 and 1931 8-9, 32-35 m 1934 1931 $-8-9,48-49,56-59$ in $1929-34$

Deficiency table showing effect of droughts on stream flow

Discharge of streams. See Stream flow.

Domestic water supplies, effect of drought

on

Drought relief ............. $3738,41-45,62-65,71-74$

Droughts, areal extent of ................ 2-3, $5-6,32-33,46,56-58,66-68, \mathrm{pl} .1$ carry-over effect of ............... 30-32, 70-71 causes of comparison of, during period 1881 to 1934 . 3, 65-69, pl. 1 damage from, alleviation of ......... $37-38$, 41-45, 62-65, 71-74

factors involved in to crops to navigation. $39-41,61$ to power plants $38-39,61$ to recreational facilities............. 41,61 to vegetation .............. $32-35,56-59,68$ to water supplies _... _. _ _ $36-37,59-60,68$ to wild life 41,61
Droughts, definition of Page

frequency of

\section{2} precipitation and stream flow as indexes

$$
\text { to . . }
$$
records of, interpretation of........... $35,65-71$ sources of.

relief measures for . .... 37-38, 41-45, 62-65, 71-74 severity of ............. 2-3, 10-11, 65-69, pl. 1 stream flow as index to...... 69-70 (and table) Dust storms, occurrence of................ 50-52

Economic aspects of shortage of water. .... 5, 71-74 Edaphic adaptation . . ....................... 16-17 Electricity, production of, in drought years.38-39, 61 Engineering Institute of Canada, paper presented before..................... 62-64 Erosion, by wind Evaporation, diurnal fluctuations in stream flow due to...................... 18-22

Federal aid in drought relief. $38,42-43,62-65$

Garden planting for drought relief 43,73

Great Plains. See Semiarid States.

Great Salt Lake, level of

Ground water, discharge of.-. 13-15, 20-21, 26, 53-54 fuctuations in level of .......... 13, 22-26, 53-54

Health, conditions during drought..... 37-38, 60-61

Humid States, alleviation of drought damage in. $71-73$ crop yields in.......... 8-9, 32-35, 48-49, 56-58 precipitation in, tables showing - 4, 8-9, 48-49, 66 vegetation in, water requirements of ....- 15-17 years of severe drought in...... 2-3,65-68, pl. 1

Industrial water supplies, effect of drought

on........................... 37, 59-60

Inland waterways, effect of drought on... 39-41, 61 Irrigation, conservation of water for........... 60,63 domestic water supplies developed in connection with................ 60 effect of drought on feasibility of, in arid and semiarid regions . $\quad 16$, 17,18

Jones, L. A., quoted $62-64$

Lakes, development of, for recreation and for bird refuges................ 61-64 effect of drought on

"Live-at-home program" for agriculturists... 73 Livestock, feed for ...................... 43-44, 58-59 water supplies for.................... 62-64

Loess, movement of, by wind............... 51-52 Lynch, H. B., quoted...................... 68-68 
Page

Navigation, effect of drought on.

$39-41,61$

Pasture land, effect of drought on ............ 58-59

Pellagra, foods to prevent...................... 37-38

Plants. See Crops; Vegetation.

Pollution of water, avoidance of .............. 72

due to drought. ........................ 37

Power, effect of drought on production of - 38-39, 61

Precipitation, by States, annual, 1881-1934_.. 4 (table 1), 66 (table 14), 75-103

by States, for major drought years.......- pl. 1 for six lowest years............ 66 (table 15)

June-August, 1930 and 1931...... 8-9, 33-35

June-August, 1934_............... 57

monthly, 1929-31_.................. 75-103

crop yields in relation to................ 7-10,

$32-35,48-49,56-59$

deficiency in, drought defined in terms of.

tables and diagrams showing .......... 3 $8-10,30-31,48-49,66,67$

discharge of water received by $\ldots . . . .11-26,53-54$ distribution of, areal..........- 4 (and table 1), 65,66 (table 14)

seasonal $8-9,16,33-35,47-50,57$

fluctuations in annual amount of........ 65-69 records of, available.

interpretation of................. 35, 65-69, 71 stream flow in relation to, comparison of records of................. 15-16, 25-32

stations used in study of............. $\quad 70$ trends in California since 1769........... 68-69 utilization of, by plants.................... 14-21

Public water supplies, effect of drought on... 36-

improvement of $36-37,60,63$

Rainfall. See Precipitation.

Recreational uses of water.

Red Cross. See American National Red Cross.

Relief in drought areas.... 37-38, 41-45, 62-65, 71-74 Reservoirs, effect of drought on ......... 35, 56-58,60 Rivers, run-off of. See Stream flow.

Root zone, features of.

Run-off. See Stream flow.

Seeds for relief gardens. 43,45 Semiarid States, alleviation of drought dam. age in. $71-74$

belt including

crop yields in. $9,32-34,49,57-58$ precipitation in, tables showing -..... 4, 9, 49,66 vegetation in, water requirements of..... 16-18 years of severe drought in.... 2-3, 17, 65-68, pl.1

Silt, movement of, by wind................... 51-52 Sources of information Stock, feed for......................... 43-44, 58-59 water supplies for ......................... 62-64
Page

Stream flow, deficiency table................. 30 effect of drought on.... 25-32, 39-41, 54-55, 69-70 evaporation and transpiration causes of loss in ................................. 18-22 fluctuations in, diurnal.................. 18-21 general .................................. 25-32

lag in recovery of.......................... 30-32 minimum, at selected stations........... 69 70 (and table)

plant growth a cause of fluctuations in.-. 15$16,18-21$

precipitation and, comparison of... 15-16, 25-32 stations used in study of............ $\quad 70$ records of, interpretation of.............. 69-71 period covered by.................... 4 tables and diagrams illustrating ......... 16, $27-31,64-55,70$ Subsistence farming -.......................... 72-73 Surface water. See Lakes; Reservoirs; Stream flow.

Temperature, in 1930 and $1931 \ldots \ldots \ldots . . . . . .11,12$ in 1934........................... 48-49,50,51 Transpiration, diurnal fluctuations in stream flow due to. 18-22

Vegetation, adaptation of, to environment..- $\quad 16-$ 17,56

carry-over effects of drought on ............ $\quad 70$ drought damage to.............. 32-35, 56-59, 68 factors affecting ................ 11-18, 32-35, 57, 68 water requirements of .................... 14-21

Water, pollution of, avoidance of............ $\quad 72$ quality of, affected by drought............ $\quad 37$ recreational use of.......................... 41, 61 storage of, artificial. ............. 16, 35, 56-58, 60 natural....................................... 13,53 utilization of, by plants................... 14-21 See also Ground water; Stream flow.

Water power, reduced output of, during drought.......................... 38-39, 61

Water supplies, development of as relief proj-

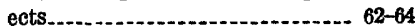

economic aspects of shortage in....... 5,71-74 effect of drought on................. 36-37, 59-60 efficiency in use of........................ 71-74

Water table, fluctuations of............- 22-26, 53-54 position of................................ 13

Water year, beginning of .................... 16

Wells, additional water supplies from..... $36,59-60$ effect of drought on -...-.-. 22-26, 36, 53, 59-60 fluctuations of water level in............... 22-26 Wildlife, effect of drought on................. 41,61 refuges developed for.................... 63-64 Wind, during drought.................... 11, 50-52

Zone of aeration, features of Zone of saturation, features of................ 13-14 